Carlos Augusto Pereira dos Santos Organizador

\title{
Nossa Gente,
}

Nossa História

O Ceará Republicano 

Carlos Augusto Pereira dos Santos

Organizador

\section{Nossa Gente, \\ Nossa História \\ O Ceará Republicano}

Sobral-CE

2019
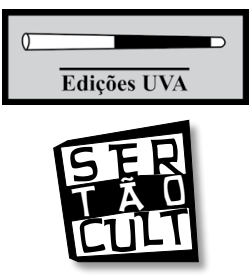
Nossa Gente, Nossa História. O Ceará Republicano

(c) 2019 copyright by Carlos Augusto Pereira dos Santos (Organizador)

Impresso no Brasil/Printed in Brasil.

Efetuado depósito legal na Biblioteca Nacional.

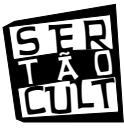

Rua Maria da Conceição P. de Azevedo, 1328

Renato Parente - Sobral - CE

(88) 3614.8748 / Celular (88) 99784.2222 / 99846.8222

sertaocult@gmail.com / mammarco@gmail.com

Conselho Editorial

Adriana Brandão Nascimento Machado

Carlos Augusto P. dos Santos

Isorlanda Caracristi

Nilson Almino de Freitas

Regina Celi Fonseca Raick

Telma Bessa Sales

Virgínia Célia Cavalcante de Holanda

Coordenação Editorial e Projeto Gráfico

Marco Antonio Machado

\section{Revisão}

Antonio Jerfson Lins de Freitas

Foto da capa

Passeio público, Fortaleza, 1919

Catalogação na publicação

Leolgh Lima da Silva - CRB3/967

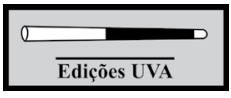

Av. da Universidade, 850 - Campus da Betânia - Sobral - CE

CEP 62040-370 - Telefone: (88) 3611.6613

Filiada à

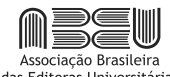

Associação Brasileira

das Editoras Universitárias

Reitor

Fabianno Cavalcante de Carvalho

Vice-Reitora

Izabelle Mont'Alverne Napoleão Albuquerque

Diretora das Edições UVA

Maria Socorro de Araújo Dias

Conselho Editorial

Maria Socorro de Araújo Dias (Presidente) Alexandra Maria de Castro e Santos Araújo Ana Iris Tomás Vasconcelos

Carlos Augusto Pereira dos Santos Claudia Goulart de Abreu Eneas Rei Leite

Francisco Helder Almeida Rodrigues Israel Rocha Brandão

Izabelle Mont'Alverne Napoleão Albuquerque Maria Adelane Monteiro da Silva

Maria Amélia Carneiro Bezerra Maria José Araújo Souza

Maria Somália Sales Viana Maristela Inês Osawa Vasconcelos Raquel Oliveira dos Santos Fontinele Renata Albuquerque Lima Simone Ferreira Diniz

Tito Barros Leal de Ponte Medeiros

Virginia Célia Cavalcanti de Holanda

N785 Nossa gente, nossa história: o Ceará republicano. / Santos, Carlos Augusto Pereira. (Org.) - Sobral: Sertãocult; Edições UVA, 2019.

294p.

ISBN: 978-85-67960-25-8

ISBN: 978-85-9539-035-5

DOI: $10.35260 / 67960258-2019$

1. Sertão. 2. Educação 3. Cultura.

I. Título. II. Santos, Carlos Augusto Pereira. 


\section{Sumário}

Nossa História, Nossa Gente. À guisa de prefácio e apresentação / 5

\section{Parte 1 - O sertão da água, da seca e da religião}

1. "O rio é uma riqueza imensa": Usos e tradições sobre a importância da água no sertão de Santa Quitéria-CE (1960-1980) / 9

Maria Malena Paiva Mesquita

2. As mulheres e a seca: sobrevivência feminina em tempos de escassez em Varjota-CE (1980-1990) / 19

Francisca Clédia Sousa de Oliveira

3. Os bastidores da seca: exploração dos trabalhadores nas frentes de serviço do Açude Araras, Varjota-CE (1951-1958) / 33

Letícia Rodrigues Gonçalves

4. Políticas públicas de combate à seca no município de Croatá-CE (19831996) / 45

Caubi Alves Braga

Naiane Nobre Martins

5. A seca e as obras de socorro no Ceará republicano (1889-1915) / 55

Pedro de Souza Filomeno Filho

6. Entre fanáticos e cassacos: a presença da Irmandade da Cruz nos sertões do norte do Ceará (1900-1903) / 65

Raimundo Nonato Fernandes

\section{Parte 2 - O mundo do trabalho e da educação}

7. "Se a gente fosse viver só de trabalhar pros outros a gente morria". Memórias da Casa Grande: moradores, rendeiros e agregados na cidade de Alcântaras-CE (1907-1920) / 85

Jaiana Kelly Rodrigues Alcântara

8. "Depois foi que veio essa modernização": as transformações nos engenhos de cachaça artesanal em Alcântaras-CE (1960-2000) / 95

Adelina Lopes Guimarães

9. Sindicato dos Trabalhadores Rurais de Coreaú-CE: criação e processo de organização (1965 a 1990) / 103

Sebastião Ferreira Carneiro

10. O Ensino de História e cultura indígena em Hidrolândia-CE: a Lei 11.645 de 2008 e os meios para uma descolonização da imagem do indígena / 119 Paulo Ênio de Sousa Melo

11. Práticas de combate ao analfabetismo no Ceará / 133

João Henrique Brito Lima 
12. A Educação na República / 145

Natanael Lopes Alves

\section{Parte 3 - Culturas e sociabilidades diversas}

13. Historiografia e cinema: percepções da diversidade na sétima arte / 157 Vinícius Pereira de Sousa

14. Espaços de sociabilidades homoafetivas em Sobral-CE (1950-2018) / 175 Alan Silva de Morais

15. "Zé Maria mulher": representatividade e resistência umbandista em Sobral / 185

Antonio Tarciano Aragão Sousa

16. "Mas digo uma coisa, não é a gente que cura, mas sim Deus". Memórias de benzedeiras em Alcântaras-CE / 197

Maria Deiziane Lino

17. "Eu entrei nessa brincadeira quando eu era um menino". Memórias sobre o reisado groairense / 205

Raimundo Sousa Alves

18. Corpo em movimento, Street Dance e agências de patrimonialização cultural: uma experiência de pesquisa (Sobral-CE) / 221

Cleane dos Santos de Medeiros

Nilson Almino de Freitas

19. Ambivalências poéticas nas canções de Belchior - a ida e o regresso / 233 Francisco Sávio Barbosa do Nascimento

\section{Parte 4 - Política e economia nas tramas do cotidiano}

20. A Ação Integralista Brasileira (AIB) e sua influência no interior do Ceará: memórias do Integralismo em Ibiapina / 247

Odail José Martins Freire

21. A economia e seus impactos: Uma análise sobre Camocim (1930-1950) 1255

Valério Samaronni Morais de Queiroz

22. Emissoras de rádio de Camocim: o relacionamento com grupos políticos, cultura e comércio locais (1980-1989) / 261

Maely Alves de Mesquita

23. A história da República passa por aqui! Camocim-CE (1889-1950) / 273

Carlos Augusto Pereira dos Santos 


\section{Nossa Gente, Nossa História. À guisa de prefácio e apresentação}

No semestre 2018.1, propusemos aos alunos da disciplina de História do Brasil III que escrevêssemos sobre a nossa gente, aquela que está mais próxima de nós, convivendo conosco ou mesmo um pouco distante num passado recente. A ideia era que se aproveitassem as pesquisas que estavam sendo feitas para a escrita dos seus respectivos TCC's e adaptássemos as temáticas para o período republicano, tempo que converge ao estudo da mencionada disciplina acima. Teríamos, portanto, uma espécie de painel do Ceará República, pelos temas levantados nas primeiras aulas. Poucos alunos tiveram de sair do seu raio de pesquisa para cumprir com o objetivo final - publicar um livro com os artigos dos alunos em fase final de curso.

Durante todo o semestre, tivemos a discussão de uma obra que nos serviu de guia e inspiração: Histórias da Gente Brasileira. Volume 3, República. Memórias (1889-1950), de autoria da historiadora Mary Del Priore. Foi uma experiência interessante, pois cada vez que as discussões eram estabelecidas, sentíamos que aquelas histórias contadas, no caso do terceiro volume, narradas pelo viés da memória, eram questões que nos diziam respeito, que já ouvíramos contar pelos nossos pais e avós.

Por outro lado, constatamos também que estávamos espacialmente longe dos exemplos contados nas diversas partes do livro referenciado. Apesar do fôlego e do abarcamento da obra empreendida por Mary Del Priore ${ }^{1}$, o Nordeste e, especialmente o Ceará, pouco são citados. Logicamente que compreendemos os limites de um projeto editorial desta envergadura e da logística de pesquisa. Para nós, longe disso ser um aspecto desmotivador, ao contrário, fez com que, como se preenchêssemos uma lacuna, jogássemos todas as nossas forças na construção de histórias que representassem e contassem um pouco mais de nós.

O resultado foi a escrita de vinte e três artigos, divididos em quatro partes temáticas que podem ser conferidas no sumário e ao longo do livro. Portanto, empreendemos um mergulho no universo sertanejo, falando da alegria da chegada do inverno, do inferno da seca e das práticas religiosas que beiram o fanatismo (Parte 1). Adentramos no mundo do trabalho e esticamos a jornada para compreendermos os projetos e propostas de escolarização e educação do nosso povo (Parte 2).

Histórias da Gente Brasileira é um projeto editorial escrito pela historiadora Mary Del Priore que cobre os diversos períodos da História do Brasil. Volume 1 - Colônia, Volume 2 - Império, Volume 3 - República (1889-1950) e Volume 4 (1950-2000), publicados pela Editora LeYa, 2017. 
Por outro lado, foi necessário falarmos da diversidade cultural que nos caracteriza. O que tem em comum o universo queer no cinema e as sociabilidades homoafetivas no espaço citadino? O que um pai de santo e um conjunto de mulheres rezadeiras podem nos dizer sobre a prática da cura? Quais são as fronteiras culturais entre dançadores de reisado, jovens bailarinos da periferia e a obra do cantor Belchior? São interrogações que poderão ser respondidas, ou não, lendo-se o conjunto de artigos da Parte 3. Finalizando, como a política e a economia interferem no cotidiano de uma cidade? É o que os autores propõem discutir na Parte 4, evidenciando as características singulares na história dos municípios de Ibiapina e Camocim.

Um último aviso ao leitor. Os textos aqui reunidos são de alunos em formação, mesmo estando em fase final de conclusão de curso. Expressam, portanto, suas trajetórias acadêmicas dentro de seus limites e potencialidades e devem ser entendidos e compreendidos dentro dessa dimensão. Como organizador, procurei interferir o mínimo no processo de orientação da escrita e incentivei que eles dividissem os processos de escrita com seus orientadores. Daí que, a maioria dos textos, já serem partes de suas monografias ou artigos finais de curso.

Dizer, finalmente, que foi gratificante compartilhar saberes e ensinamentos com todos vocês, por isso o faço nominalmente: Maria Malena Paiva Mesquita, Franscisca Clédia Sousa de Oliveira, Letícia Rodrigues Gonçalves, Caubi Alves Braga, Naiane Nobre Martins, Pedro de Souza Filomeno Filho, Raimundo Nonato Fernandes, Jaiana Kelly Rodrigues Alcântara, Adelina Lopes Guimarães, Sebastião Ferreira Carneiro, Paulo Ênio de Sousa Melo, João Henrique Brito Lima, Natanael Lopes Alves, Vinícius Pereira de Sousa, Alan Silva de Morais, Antonio Tarciano Aragão Sousa, Maria Deiziane Lino, Raimundo Sousa Alves, Cleane dos Santos de Medeiros, Francisco Sávio Barbosa do Nascimento, Odail José Martins Freire. Valério Samaronni Morais de Queiroz e Maely Alves de Mesquita.

Boa leitura a todos!

Carlos Augusto Pereira dos Santos (Org.)

Camocim, outubro de 2018. 


\section{Parte 1}

O sertão da água,

da seca e

da religião 



\title{
1. "O rio é uma riqueza imensa": usos e tradições sobre a importância da água no sertão de Santa Quitéria-CE (1960-1980)
}

\author{
Maria Malena Paiva Mesquita ${ }^{1}$
}

Ao fazer um passeio pelo sertão nos dias de hoje, há possibilidade de encontrarmos um espaço diferente do que muitos imaginam. Aquele sertão como o espaço deserto ou atrasado e que assim permanece, ao ser entendido em sua realidade e cultura pode dar lugar ao sertão como sinônimo de "progresso". No que diz respeito às estruturas das casas e à praticidade que a modernidade e industrialização trouxeram para o sertão, podemos elencar o uso de água encanada, luz, televisão e internet para um número considerável de residências.

É possível perceber que as pessoas que moram ou moravam na comunidade de Fazenda Passagem, no município de Santa Quitéria-CE, se admiram em dizer que "hoje as coisas estão muito diferentes, não é?". Neste sentido, compreende-se que as memórias dos depoentes apresentam uma percepção de mudança que tinha início naquele período, mas que a velocidade com que as "mudanças" acontecem atualmente é mais impressionante. ${ }^{2}$ O processo de modernização mudou os costumes e deu novos sentidos aos modos de ver a vida no sertão. Este não era um acontecimento sentido pelas pessoas inconscientemente, pelo contrário, era proposto, como veremos à frente, fazia parte de um discurso politico, econômico e cultural.

A História que vamos contar aqui está situada nas primeiras décadas do século XX, marcadas por acontecimentos intensos. Em 1914 explode a Primeira Guerra Mundial, conflito de alcance mundial e trouxe mudanças econômicas e políticas. As indústrias conheceram um grande crescimento e modernização e produção de meios de comunicação, que trouxeram mudanças também em aspectos sociais. O historiador cearense Sebastião Rogério da Ponte afirma que as mudanças não foram apenas econômicas

Graduanda do Curso de História da Universidade Estadual Vale do Acaraú - UVA. Bolsista BIC/ FUNCAP - UVA.

Luiza Paiva Moura, 57 anos, Costureira. Entrevista realizada pela autora em 21 de agosto de 2018, Sobral-CE. 
ou de ordem política, a modernidade do século XX "afetou profundamente o cotidiano e a subjetividade das pessoas, alterando seus comportamentos, seus modos de perceber e sentir"' . Como exemplo, temos as transformações na cidade de Fortaleza, que com a passagem do século XIX para o XX despertou para o novo século "no auge da Belle Époque", $\mathrm{O}$ século XX dava continuidade às novidades produzidas com a "revolução cientifico tecnológica (1850-1870)" ${ }^{\prime \prime}$ que se expandia pelo mundo levando novas tecnologias que traziam a modernização das cidades, mas que também chegavam às casas e vidas das pessoas.

O Brasil inicia o novo século com um novo modelo político, com a "proclamação da República em 1889, e as modificações que vieram com ela transformaram vários aspectos da gente brasileira" ${ }^{\prime \prime}$. Assim, o país tinha 0 objetivo de caminhar para um futuro de ordem e progresso, referindo-se tanto às mudanças politicas, econômicas, quanto na mudança de hábitos que a modernidade dos novos tempos requeria.

Mas, como bem diz Mary Del Priore, "o país era feito de vários Brasis", partes de uns pais que tinham "tempos diferentes"7. Para tanto, este artigo tem o objetivo de trazer para o campo historiográfico o cotidiano dos moradores no sertão durante a segunda metade do século XX, apresentando a relação dessas pessoas com as fontes de água, mais precisamente o Rio 10| Groaíras, percebendo seus usos e significados culturais e também sociais nas tradições e vivência do sertanejo, bem como também discutir as mudanças dos usos do rio, a chegada das mudanças de hábitos e costumes que os novos tempos fizeram nesses espaços.

Para isso, buscamos discutir dentro do recorte temporal dos anos de 1930 a 1960, percebendo essas representações através das memórias de moradores da comunidade de Fazenda Passagem, utilizando como fontes seus depoimentos, pois compreendemos que "o sujeito histórico não é pensado como uma abstração, ou como um conceito, mas como pessoas vivas, que se fazem histórica e culturalmente" ${ }^{\text {. }}$ Este texto, portanto, se justifica na elaboração da escrita da história a partir desses sujeitos inseridos em um desses "brasis" de que fala Mary Del Priore, rememorando suas tradições, no cotidiano de um período marcado por muitas mudanças em âmbito mundial, mas que acabaram chegando a esses espaços mais remotos, embora que em "tempos" diferentes.

PONTE, Sebastião Rogério. A Belle Époque em Fortaleza: remodelação e controle. In: SOUSA, Simone de. (Org.). Uma nova história do Ceará. Fortaleza: Fundação Demócrito Rocha, 2000, p. 163.

Id. Ibid., p. 163.

Idem.

6 DEL PRIORE, Mary. Histórias da gente brasileira, V. 3: República - Memórias (1889-1950). Rio de Janeiro: LeYa, 2017, p. 15.

Id. Ibid., p. 15.

8 KHOURY, Yara. Narrativas Orais na investigação da História Social. Projeto História. São Paulo, 22 de jun., 2001, p. 80. 


\section{Dia a dia no sertão: água do rio serve para beber, comer, trabalhar e se banhar}

É preciso que compreendamos que as mudanças que se fazem e refazem pelo mundo não chegavam à zona rural ou no sertão na mesma velocidade com que se viam nas cidades; cada espaço é constituído de uma "realidade histórica" . Todavia, é preciso que contextualizemos o período, pois a partir deste entendimento poderemos compreender as relações do cotidiano dos homens e mulheres daquele período e naquele espaço ao qual iremos trabalhar.

É certo que o leitor fará a pergunta: por que falar da relação das pessoas com o rio? E respondemos que, já que falamos das transformações ocorridas durante o tempo, onde novas coisas surgem, outras perdem a utilidade ou apenas tem redefinição de suas funções. Colocamos coisas, pois não cabe aqui enxergar o rio como um objeto. Aqui pretendemos entender a relação do homem com a natureza; como o homem do sertão no período destacado enxerga e sente o rio, diante da realidade da vida do sertanejo, do pequeno proprietário que pauta seu trabalho na agriculta de subsistência, e esta vivência tem relação íntima com o homem deste espaço, para com a água, a chuva, com o ciclo da natureza: "[...] é muito importante, mulher, a gente morar na beira do rio. Ter água favorável, prá lavar, prá gente tomar banho, utilizar, beber. [...] Muito importante, a coisa... Ave Maria, prá mim era a riqueza. Morar na beira do Rio Groaíras". Essas são as palavras de Luiza Paiva Mou$\mathrm{ra}^{10}$, moradora durante toda sua vida da comunidade de Fazenda Passagem, às margens do Rio Groaíras.

As relações de trabalho perpassam na construção da cultura e das relações sociais, percebendo-as na religiosidade, música, alimentação entre outras ações em sociedade. Nas zonas urbanas, essas relações se reproduziam de maneira diferente. Para elencar isso, podemos dialogar com a historiadora Kenia Rios, ao falar do período das secas na História do Ceará ${ }^{11}$. Ela faz menção às reações e ações construídas pelos moradores da cidade de Fortaleza ao receber as grandes levas de "retirantes" vindos das áreas rurais. A autora propõe que a chuva, tão esperada pelos retirantes, para os moradores da urbe atrapalhavam suas festas. "No carnaval de 1932, os foliões não tinham suas fantasias ameaçadas pelas chuvas que costumavam cair durante todo o mês de fevereiro. $\mathrm{O}$ sol prometia não abandonar a folia daquele ano"12.

\footnotetext{
9 MAIA NETO, Emy Falcão. Do Banho "de chuva" e outras "danações": Sociabilidades nos "tempos de meninos" em Fortaleza. (1890-1940). In: Revista de História Saeculum. João Pessoa, jul./dez. 2012, p. 95.

10 Luiza Paiva Moura. Entrevista já citada.

11 RIOS, Kênia Sousa. Isolamento e poder: Fortaleza e os campos de concentração na seca de 1932. $2^{\mathrm{a}}$ ed. Fortaleza. Editora: Museu do Ceará. 2014.

12 Ibid., p. 32.
} 
Desde os primeiros tempos de convivência do homem com o semiárido - região onde fica a maioria dos estados do Nordeste, tendo o Ceará a maioria do seu território dentro dela, este teve de conviver com os períodos de irregularidades de chuvas. Esta irregularidade se converteu numa característica do Nordeste diante de diversos processos históricos, tendo toda uma cultura de sentidos sobre a relação do nordestino para com a seca. Sobre a elaboração dessas significações, o historiador Frederico de Castro Neves afirma que, "quando falamos em seca, estamos nos referindo aos terríveis acontecimentos sociais", sendo "que este fenômeno climático, por si só, não causa desgraças sociais nem favorece ao desenvolvimento" ${ }^{13}$. Assim, o autor propõe que alguns dos maus hábitos e valores construídos histórica, social e culturalmente pela sociedade brasileira, aqui em específico, as pessoas que estão ligadas diretamente aos estados que sofrem com as secas, como a corrupção, economia de subsistência, é que colocam a sociedade em um ponto vulnerável diante das irregularidades climáticas.

Os homens e mulheres que estavam antes da ocupação no período colonial compreendiam a terra numa relação de reciprocidade, eles faziam parte da natureza. Após a colonização, percebe-se a inserção de novos valores para com ela. Os colonizadores davam a terra o valor comercial, buscavam explorar em prol das riquezas que poderiam arregimentar. Neste período, o rio 12 tem papel importante para as entradas no sertão, pois serviam como "caminhos naturais para explorar os espaços desconhecidos"14. Os principais rios e poços davam a terra o valor, sendo as margens dos rios pontos estratégicos para a instalação das fazendas de criação de gado e plantações. No entorno dessas fazendas foram erguidos povoamentos, depois vilas e tantas cidades vistas atualmente, como Sobral, Santa Quitéria, Forquilha, Groaíras, dentre outras.

As casas do "interior" ou do sertão, fazendo menção ao espaço rural, são núcleos de uma indústria doméstica; estas servem para o espaço de morada, mas também de trabalho. Próximo a casa há o curral, a criação de animais domésticos, as plantações de comida. Como já exposto acima, desde outros períodos o rio oferece facilidade à sobrevivência do homem, aqui especificamente, ao sertanejo. As casas, em sua maioria, são localizadas nas proximidades dos braços dos rios ou riachos. Tal localização facilita no momento de ir buscar água para beber e cozinhar, tomar banho e criar os animais.

Nas casas não havia banheiros, sendo necessário o deslocamento para os rios para tomar banho, lavar roupa, buscar água para beber. Luiza Paiva

\footnotetext{
NEVES, Frederico de Castro. A Seca na História do Ceará. In: SOUSA, Simone de (Org.), Op. cit., p.100-101.

14 PINHEIRO, Francisco José. Mundos em confronto: povos nativos europeus na disputa pelo território. In: SOUSA, Simone de (Org.), Op. cit., p. 17.
} 
Moura diz que os costumes eram diferentes naquelas épocas, as pessoas não tinham acesso às "facilidades" que hoje em dia se têm:

Tinha não. Ninguém tinha banheiro em casa. Tomava banho, ia tomar banho no rio, de manhã e à tardinha. Fazia as cacimbas na areia, nas areia, os rio, quando ficava aquele poço no verão a gente fazia aquelas cacimba debaixo da oiticica na sombra, a água era gelaaada!!! Parecia água de geladeira! Prá gente tomar banho ${ }^{15}$.

O hábito de tomar banho no rio era necessário, o uso do rio era uma prática habitual, pois não se conhecia ou se tinha acesso a outro, caso não houvesse possibilidade de tomar banho no rio por conta de alguma doença ou no caso das mulheres, algum "incômodo" em referência ao período menstrual, o banho se deslocava para a casa: "De manhãzinha. À tarde ninguém ia. Levava água na cabeça ou no jumento, prá esfriar e tomava banho em casa, só ia de manhã pro rio, a tarde não ia não. Ninguém tinha banheiro, tomava no ponto reservado assim detrás da casa, assim numa área”. Buscava-se, portanto, um espaço escondido, uma área privada dos olhares dos curiosos ou desavisados, principalmente do sexo masculino. Havia também o pudor entre os sexos, as mulheres não podiam tomar banho nos mesmos lugares em que os homens. Sobre isso ela diz que "era homem pra um lado e mulher pra outro! Tinha, tinha os local, tomar nas oiticica, aonde a gente se escondia pra tomar banho"16.

$\mathrm{O}$ ato de tomar banho está ligado à necessidade de se estar limpo, longe de micróbios que podem trazer doenças, ou apenas longe do mau cheiro dos corpos. Essa construção se deu a partir do século XX, com os valores e sentidos que chegavam com a modernidade. Elizabete Kobayashi e Gilberto Hochman ${ }^{17}$ , ao discutirem sobre a relação entre consumo e mudança de hábitos por meio de novos produtos industrializados, relacionados à saúde e à higiene durante a segunda metade do século XX, apontam que a vida moderna tinha com o ideal uma vida higiênica, assim o banho e a limpeza estavam sendo inseridos como sinônimos de saúde e antônimos de atraso.

A dissolução desses novos hábitos, segundo os autores acima referidos, se deu principalmente com o alcance da imprensa e os anúncios publicitários veiculados por ela. Os anúncios vendiam sabonetes, perfumes, cosméticos em geral. No tocante a este movimento, os autores apontam que:

Luiza Paiva Moura. Entrevista já citada.

16 Luiza Paiva Moura. Entrevista já citada.

17 KOBAYASHI, Elizabete. HOCHMAN, Gilberto. O “CC" e a patologização do natural: higiene, publicidade e modernização no Brasil do pós-Segunda Guerra Mundial. In: Anais do Museu Paulista. São Paulo. N. Sér. v. 23. n.1, p. 67-89. jan.- jun. 2015, p. 67. 
No período compreendido entre a segunda metade dos anos 1940 até a primeira metade dos 1960, o Brasil experimentou a consolidação de um mercado de bens de consumo e de um parque industrial que se mesclou à experiência democrática do período. Esse mercado consumidor vinha se constituindo desde o início do século XX. Contudo, no período em questão, este processo acelera-se, com o adensamento de uma classe média urbana, com a modernização da imprensa e da publicidade no Brasil - dinâmicas sob a égide da ideia de desenvolvimento. Esses novos bens materiais e simbólicos traduziam, também, a aspiração à modernidade e ao progresso desses setores urbanos e da própria elite política ${ }^{18}$.

Na zona urbana há maior influência da imprensa, no entanto, nas áreas rurais os produtos de origem natural eram mais utilizados, como o sabão feito em casa, de óleo de oiticica ${ }^{19}$ e de gordura de animais, como explica Luiza:

Sabão? Fazia sabe de quê? O sabão era feito do óleo de oiticica. A gente comprava a potassa, soda caustica, que era chamada. A gente comprava, e apanhava na época que tinha a oiticica, quando, numa época que tinha, a gente apanhava e deixava pra um ano, dois, fazia o azeite, a gente quebrava a oiticica, tirava o miolo dela, passava no moinho, aí botava dento duma vazia no fogo, quando começava a ferver aí subia o óleo, o azeite. Aquele azeite, a gente tirava todinho e guardava nas garrafas, guardava dentro dumas vazia de barro, umas panela de barro, uns potes de barro, aí a gente ia fazer o sabão, aí ajuntava alguma gordura, de algum bicho que a gente ia matando, e aí ajudar a guardar aquelas gorduras, misturava gordura de gado, de criação, do que tivesse ${ }^{20}$.

E quando questionada se o sabão ficava cheiroso, ela afirma com bastante entusiasmo: "Ficava! A gente cozinhava bem, ficava aquele cheirinho de oiticica. A gente lavava roupa só no rio, lavava até a cabeça porque era bom pra caspa, ficava com o cabelo lindo"21.

Mas sem o acesso democrático à água ou aos produtos, "a boa aparência física, resultado do 'corpo moderno', limpo e higienizado ainda não se democratizara"22. Ainda segundo Mary Del Priore, "havia pessoas que consideravam o banho um mal necessário" ${ }^{23}$, não se tinha este hábito de tomar banho

\footnotetext{
Id. Ibid., p. 68

19 A oiticica (Licania rigida) é uma planta da família Chrysobalanaceae, endêmica na caatinga e na vegetação típica da faixa de transição entre o sertão semiárido do Nordeste e a região Amazônica (Mata dos Cocais). Nesta mata se encontra a palmeira babaçu, da qual é extraído o óleo utilizado na fabricação de cosméticos, margarinas, sabões e lubrificantes.

20 Luiza Paiva Moura. Entrevista já citada.

22 DEL PRIORE, Op. cit., p. 309
}

21 Idem.

23 Idem. 
todos os dias. Luiza Paiva Moura conta que seu pai não tomava banho todos os dias:

Era assim: se ele ia trabalhar, olha, ele tinha um terreno na $\mathrm{Mu}$ tamba, ele tinha que passar o rio né? Todo dia que ele vinha ele tomava um banho no rio, ele passava o rio tomava um banho, trazia aquela coisinha dele, quando a gente tinha cacimba, ele tomava banho. Aí quando era de tarde, ele era difícil tomar banho. Agora tomar banho bem banhado mesmo, dia de domingo de manhã ele ia logo tomar banho, tirar a barba $[\ldots]^{24}$.

O banho do rio pode significar higiene, mas, para além do espaço de prática de hábitos individuais, servia também como lugar de sociabilidades e lazer. Sobre isso Luiza diz que "a gente brincava quando ele dava as enchentes no inverno, era muito bom a gente lavar roupa, pescar. Pegava o peixe com o anzol. Quando as águas diminuíam, a gente pegava com um landuá"

A água para beber e cozinhar alimentos era levada para casa e, considerando as distâncias, isso significava tarefa diária a ser cumprida pelas mulheres. Quem não tinha o suporte da força animal como o jumento, transportava a água nos potes ou latas na cabeça, utilizando a "rudia" (rodilha) - uma peça de pano enrolada e posta sobre a cabeça como uma coroa, para diminuir o desconforto do peso.

O trabalho nos roçados era realizado por todos, pouco se distinguia o gênero no momento do trabalho, sendo que ele significava a alimentação de toda a família. Francisco Antonio de Paiva Cunha ${ }^{26}$, agricultor e morador da mesma Fazenda Passagem, diz sobre a vida naquele tempo: "Era bem, era sempre focado na agricultura mesmo. Na época tinha muito... a gente plantava muito algodão, a gente colhia oiticica, palha de carnaúba, a gente sobrevivia disso. E da agricultura também". Antonio é um dos irmãos mais jovens de Luiza; ele vivenciou um período posterior a Luiza, mas demonstra em sua fala que aquele cotidiano era voltado ao trabalho na agricultura, sendo que esta atividade era tão importante para a manutenção da casa e da família que não havia tempo para estudar quando mais jovem. Sobre isso ele diz que: "É, tinha que trabalhar, aí o tempo sobrava muito pouco prá gente ir estudar”27.

Assim, o trabalho estava em todos os espaços, em casa, com as tarefas diárias que requeriam esforço, como o transporte de água, assim como na lida com as vacas ou nos roçados, fazendo "brocas" - o corte ou arranca do mato seco para preparar aquele espaço para a queima, para servir de roçado

Luiza Paiva Moura. Entrevista já citada.

25 Luiza Paiva Moura. Entrevista já citada.

26 Francisco Antonio de Paiva Cunha, 52 anos de idade, Agricultor. Entrevista realizada pela autora em 16 de maio de 2017. Fazenda Passagem, Santa Quitéria-CE.

27 Francisco Antonio de Paiva Cunha. Entrevista já citada. 
para a plantação do milho e do feijão. As plantações ficavam mais próximas dos rios, nas "croas" - as margens dos rios - lugares mais favoráveis aos plantios que necessitassem de mais irrigação, como a:

[...] plantação de cheiro verde, de batata doce, na beira do rio Groaíras, e tinha capim, pro gado. E plantação de milho e feijão nas croa do rio. E ai tudo era, de onde a gente tirava o sustento. No verão a gente aguava com motor, aqueles que tinha condições de ter. Aquele que não tinha, às vezes fazia mesmo aguação só em mão, jogando com a vasilha, com a cuia, jogando a água pra as plantação na croa do rio. Nas margem do rio a gente chama $\mathrm{croa}^{28}$.

\section{Antes do açude Edson Queiroz}

Uma questão que se faz presente na região são os períodos de secas, que ocorrem mais no semiárido, e deve ser levantada neste trabalho. Faz-se importante na medida em que discutimos os hábitos do homem do sertão vinculados à sua proximidade ou necessidade das fontes de água para sua sobrevivência. Ao perguntarmos a Luiza Paiva se ela tinha lembrança de uma seca

16 que tivesse afetado sua região e sua família com a falta de água, ela afirma que não havia vivenciado um momento em que não tivesse água para beber ou utilizar. Mas que, em anos de pouco ou nenhum inverno, o trabalho para encontrar água era maior, pois,
[...] só que tinha que fazer umas cacimbas muito funda, e tinha uns arado que os homem inventava de madeira, aí botava um cavalo pra puxar, a ali eles fazia aquela areia, puxava areia pra trás, até dá na água. Aí ficava aqueles poço pros gado beber. E ali a gente utilizava aquelas cacimbona funda pra tirar água pra lavar, lavava roupa nas cacimbas, botava água nas vazia pra lavar ${ }^{29}$.

Após o nascimento da entrevistada no ano de 1961, a pior seca seria a de 1978 a 1982. Podemos questionar que Luiza não tem lembrança de uma seca tão forte por morar às margens do rio, ou por que a memória da entrevistada compreendeu que a seca estava tendo como referência apenas a falta de água. Desde o século passado, os governos passaram a realizar políticas e departamentos de "ajuda" e controle para os retirantes da seca, como o DNOCS (Departamento Nacional de Obras Contra as Secas) e a SUDENE (Supe-

\footnotetext{
28 Luiza Paiva Moura. Entrevista já citada.

29 Luiza Paiva Moura. Entrevista já citada.
} 
rintendência do Desenvolvimento do Nordeste $)^{30}$, que organizavam obras públicas, como a construção de barragens e açudes, distribuíam bolsões cestas de alimentos - em períodos de seca. Uma dessas obras foi a construção do Açude Edson Queiroz, no leito do Rio Groaíras, concluído em 1987.

Depois da construção do açude, o Rio Groaíras passou a ter água corrente durante todo o ano. A instalação do açude proporcionou facilidade na vida dos moradores. Ao ser questionada sobre como as pessoas que moram no sertão utilizam a água do rio, a nossa entrevistada afirma que "tem facilidade, porque tem água, tem os motor pra puxar água do rio pra casa, e o rio agora tem a água, é permanente, descendo na margem do rio, aí tem água encanada nas casas"31. Ela diz que esta facilidade é consequência da construção do açude, visto que as dificuldades em se obter água ficaram para antes: "porque isso aí era antes do açude Edson Queiroz, aí agora tem o açude nas cabeceiras do rio, aí agora a água desce" ${ }^{\prime 2}$.

No tempo presente as pessoas da comunidade utilizam água nas torneiras, pois motores puxam a água para as casas. Os banhos de rio e as lavagens de roupa no rio são uma escolha, pois há casas com lavanderia, e os banhos são apenas lazer e apreciação da natureza - todavia, não queremos generalizar os fatos, infelizmente não são todas as famílias que possuem as "facilidades" dos tempos modernos, muitas ainda não tem base financeira para alcançar esses usos.

A água para beber era levada no lombo do jumento e retirada da cacimba de areia, mais clara, por ser mais limpa. Ao chegar em casa era colocada nos potes de barro e ali a água ficava gelada, como a de geladeira. Geladeira que veio chegar muito tempo depois da energia elétrica. O tempo corre diferente em cada canto do Brasil, concordamos com Mary Del Priore. As memórias trazem a descrição detalhada de cada gesto feito naquele tempo, e isso nos foi útil para compreendermos como aquele tempo e as mudanças que aconteciam a cada instante eram sentidas por quem o vivia, porque a subjetividade de cada narrador é expressa a partir da forma como este individuo foi construído na sociedade, e como ele se entende dentro dela.

Por fim, as mulheres e homens do espaço que conhecemos aqui relembraram e falaram das suas vivências no período que escolhemos como recorte, mas também falaram de um período que o antecedeu, a partir do presente em que estão. $\mathrm{O}$ que permaneceu disso foi a significação das práticas passadas do homem sertanejo que hoje se constroem como tradições, a cultura em torno do rio e sua valorização como fonte de vida e energia para gerações

\footnotetext{
NEVES, Op. cit., p. 80.

Luiza Paiva Moura. Entrevista já citada.

Idem.
} 
Nossa Gente,

Nossa História

o Ceará Republicano

antepassadas e presentes. Acreditamos que o leitor entendeu por diversos caminhos que o rio se faz presente nesta cultura sertaneja. Por fim, podemos concluir com as palavras de orgulho e saudade que a memória de Francisco Antonio de Paiva Cunha, que diz: "O rio é uma riqueza imensa" 33 . 


\title{
2. As mulheres e a seca: sobrevivência feminina em tempos de escassez em Varjota-CE (1980-1990)
}

\author{
Francisca Clédia Sousa de Oliveira ${ }^{1}$
}

\section{A seca como fenômeno social conversa com as problemáticas locais}

O presente trabalho se propõe a fazer uma análise de como os períodos de escassez interferem na realidade das mulheres no que hoje concebemos como Nordeste. Em nosso texto, pensamos como a sensação em torno do fenômeno climático da seca vai mudando de acordo com o passar do tempo e as mudanças das relações sociais. Seguimos com apontamentos em volta de como o poder público vai procurando solucionar os efeitos devastadores das secas que atingem o sertão, aqui focado na região de Varjota-CE, mais precisamente na população que vive no interior do município. Em seguida, estudaremos a sociedade nordestina e sua organização social, e como isso reflete na sobrevivência feminina, nos períodos de escassez, procurando perceber como as políticas públicas vão envolvendo paulatinamente esse público e chegamos às demais formas de sobrevivência feminina encontradas, como foge à regra numa sociedade falocêntrica. Dispomos ao longo do texto de relatos dos que presenciaram períodos e com estudiosos que se propõem a pensar o cenário das relações sociais em épocas de extrema necessidade e desolação.

A região compreendida como semiárida, localizada no que identificamos hoje como Nordeste do Brasil, sempre passou por períodos de estiagem e seca. Contudo, a sensação social em torno desse fenômeno climático mudou desde a colonização desses territórios. As relações no mundo mudaram ao longo dos séculos de contato entre o além-mar e os habitantes da América Portuguesa e esses contatos se fizeram presente também na mentalidade do sertanejo. A colonização do Brasil limitou-se primeiro ao litoral, nas terras propícias à produção de cana-de- açúcar, e se manteve por algum tempo os colonizadores nessas áreas de cultivo, deixando as regiões interioranas de fora da ocupação em primeiro plano.

Graduanda em Licenciatura em História pela Universidade Estadual Vale do Acaraú - UVA, Bolsista de Iniciação Cientifica pela Fundação Cearense de Apoio ao Desenvolvimento Científico e Tecnológico - FUNCAP. E-mail: fclediaolive23@gmail.com. 
Foi o processo de separação entre a produção de cana-de-açúcar e a criação de gado que deu impulso à ocupação produtiva das terras do interior nordestino. A conhecida divisão entre as duas atividades, em áreas distintas, levou os fazendeiros da Bahia e de Pernambuco a obterem extensas sesmarias para o estabelecimento de currais fora dos domínios da lavoura, forçando, também, a interiorização por parte dos que não possuíam capital suficiente para a montagem de engenhos. Os criadores de gado foram sendo gradativamente empurrados da costa, das terras mais férteis e dos portos de embarque do açúcar para Portugal, passando a ocupar as terras do sertão ${ }^{2}$.

Com a colonização do estado que hoje compreendemos como Ceará sendo mais tardia, apesar de estar localizado na região que mais cedo foi colonizada no Brasil, a ocupação, como defendem alguns estudiosos, só se fez efetivamente a partir do século XVIII ${ }^{3}$, quando a agropecuária entra em conflito com as grandes extensões de canaviais e essa nova exploração dos recursos passa a ser interiorizada entrando em confronto com os nativos que viviam nessa área, até então não explorada. Autores como Francisco José Pinheiro defende ser a reação dos nativos um dos principais motivos a essa ocupação tardia ${ }^{4}$ e nesse período as relações foram mudando. Enquanto o conflito se interiorizava, também os contatos iam moldando a realidade naquelas áreas. Assim, negros, colonizadores e nativos passaram entre guerras e acordos a coabitar na vasta região hoje compreendida como Ceará.

Com a capitania passando a ser um ponto de ligação entre Pernambuco e as províncias do Norte, assim o território vai sento conquistado e mapeado. Devido ao clima seco, os rios são as principais rotas que facilitam a entrada nessa área, em regiões ocupadas por nativos. Toda essa movimentação vai além da economia e entra nas mentalidades dos habitantes, fazendo com que experiências tidas naturais como a seca tornem-se sociais a partir das mudanças experimentadas no Brasil e no mundo e entendemos que essas mudanças também se fazem presentes na ocupação da região hoje identificada como Norte do Estado do Ceará.

2 ALEGRE, Maria Sylvia Porto. Vaqueiros, agricultores, artesãos: origens do trabalho livre no Ceará Colonial. In: Revista de Ciências Sociais, Fort. v. 20/21 № 1/2, 1989/1990, p. 2.

3 Compreendemos mais sobre essa temática no trecho: "Se de início a ocupação se deteve às áreas litorâneas, onde a principal atividade econômica era a cana-de-açúcar, posteriormente insurgiu a necessidade de ocupação do interior da colônia. $O$ processo de interiorização foi motivado por diversos fatores, no Nordeste, por exemplo, além de uma medida preventiva à invasão de estrangeiros, os entradistas chegavam ao interior à procura de pastagem para o gado, formando, assim, as grandes fazendas que em apenas um século já se estendiam por quase toda essa região. É esse cenário que consolida a ocupação do território cearense. A colonização do Ceará que ocorre de forma tardia, com mais de um século após a apropriação do Brasil, se estabiliza com a transformação do território indígena em uma área sob o controle das atividades pecuarista." In: ALENCAR, Francisco Amaro Gomes; SILVA, Vládia. Formação territorial do Ceará: das 16 vilas originais aos 184 municípios atuais. Boletim Goiano de Geografia, vol. 35, núm. 1, jan.-abr, 2015, Universidade Federal de Goiás, Goiás, Brasil, p.54-56.

4 Para saber mais ler em Mundos em confronto Francisco José Pinheiro em Uma Nova Historia do Ceará, 2011. 
Do mesmo modo que no restante das áreas de conquista, a seca não atinge a condição de fenômeno social, tendo em vista que não interfere nas formas de relações estabelecidas, carregadas de traços medievais em aspectos como as relações de vínculos com a terra e questões como apadrinhamento e proteção que ainda eram fortes no Ceará no início da colonização. A população fixa era pequena e ficava, como no sistema feudal, sob a proteção dos grandes potentados. Em períodos de escassez, esses se faziam enquanto protetores dos menos abastados; os demais, em épocas de seca, migravam para outras regiões que não fossem atingidas pelo fenômeno. Todavia, essas relações mudam quando outras práticas de vivência chegam à colônia portuguesa nas Américas; o mundo moderno muda as formas de sociabilidades, mesmo em regiões distintas. O capitalismo, que engatinhava por volta do século XVIII, já se fazia presente, o trabalho já passa a ser até certo modo assalariado, tirando o trabalho escravo e as velhas práticas feudais de patronato, que entram em declínio, e isso vai interferir também nos períodos de seca e nas relações entra as classes nessa época.

A terra, agora objeto de aquisição de acúmulo capital, já não tem espaço para as tradições feudais e pouco a pouco sua aquisição se torna a regra; a agropecuária vai cedendo espaço para outras formas de exploração, como a atividade algodoeira e cafeeira, que modificam o mapa de circulação e as relações de poder que passam a ser sentidas de forma fortificada na seca de 1877, na qual temos, por exemplo, o "dia dos mil mortos" em Fortaleza, como nos fala o historiador Frederico de Castro Neves:

\begin{abstract}
Apesar das iniciativas governamentais e privadas, a situação em Fortaleza era caótica. Os serviços foram paralisados, os equipamentos urbanos danificados, as ruas e praças ocupadas por "embarracamentos" fétidos onde as epidemias se espalhavam com a maior facilidade. A varíola hemorrágica provoca uma grande mortalidade entre os retirantes e habitantes da cidade. O farmacêutico Rodolfo Teófilo calculou que, em dezembro de 1878, estavam acometidos pela doença cerca de 80.000 pessoas; o dia 10 desse mês ficou conhecido como o "dia dos mil mortos", pois 1.004 cadáveres foram encaminhados para o cemitério, sendo que 230 ficaram insepultos devido à sobrecarga de trabalho para os coveiros 5 .
\end{abstract}

Vão ser as novas sensibilidades a esse fenômeno que irão trazer ao público o flagelo da seca, e aí se deve a divulgação na imprensa que é permitida no Brasil com a chegada da Família Real a partir de 1808. Os jornais vão noticiar a calamidade e a tristeza pelas quais passavam as populações dessas áreas. As relações que mudaram não permitem agora que os potentados consigam ou

NEVES, Frederico de Casto. A seca na história do Ceará. In: SOUSA, Simone de. Uma nova História do Ceará. Fortaleza: Edições Demócrito Rocha, 2007, p. 83. 
mesmo queiram proteger os menos favorecidos da calamidade que se arrasta até o interior. Isso faz com que levas e levas de retirantes partam para outras áreas, tendo a capital do Estado como principal foco para a fuga do sol implacável, que ao nascer destrói toda a esperança de viver dos que necessitam sobreviver.

A seca torna-se um fenômeno que grita ao resto do país e assume distintos significados. A partir desse marco, as políticas de combate aos efeitos da seca e os acontecimentos desses períodos vão desenhando o viver no sertão. Temos, por exemplo, a defesa do historiador Durval Muniz ao delimitar isto na criação do termo "nordestino"6. Esse cenário vai se firmando a partir das secas de 1915, 1932, 1957, 1983, 1989. Seca após seca, as relações entre o homem e o fenômeno climático vão se tornando mais sociais. A criação de órgãos como DNOCS ${ }^{7}$ e SUDENE $^{8}$ surgem como abono à realidade das áreas de escassez. Contudo, as políticas públicas vão sendo apropriadas por uma minoria, devido às oligarquias que surgem com as divisões em sesmarias que encontram nesse cenário possibilidades de enriquecimento e as populações mais carentes tendem a continuar sofrendo nos períodos de escassez e desolação.

Sobre isso nos fala Durval Muniz em Nordestino: invenção do "falo". Uma história do gênero masculino (1920-1940", O tipo regional nordestino não existia até as primeiras décadas do século XX. Surgiu quase ao mesmo tempo em que o recorte regional Nordeste, ou seja, em torno da segunda metade da década de 1910. A primeira referência que encontramos ao termo Nordestino, para designar o habitante da área ocidental do antigo Norte, no Diário de Pernambuco, por exemplo, data de 15 de dezembro de 1919, quando o jornal se refere a um parecer do deputado Idelfonso Albano, do Ceará, sobre um projeto do deputado Eloy de Souza, do Rio Grande do Norte, que instituía uma caixa especial, para financiar os esforços particulares visando a irrigar as terras da região. Ao se referira um discurso proferido pelo mesmo deputado, sobre esse assunto a dois anos, o jornal o chama de "deputado Nordestino". O termo Nordestino aparece para nomear os habitantes de uma área inicialmente compreendida entre os estados de Alagoas e Ceará, sendo às vezes implicado para nomear também os habitantes do Piauí e do Maranhão, com menor frequência. Podemos contatar, no entanto, que está identidade regional vai se afirmando de forma muito lenta, convivendo, pelo menos até os anos 30. Comum outras designações como; nortista, que se preserva ainda hoje no Sul do país, Cearense, designando habitantes que migravam para a Amazônia em busca de borracha, também chamados de paroaras ou arigós, sertanejos, brejeiros, praieiros, tipos regionais que, como veremos, serão paulatinamente incorporados à figura do Nordestino".

7 "[...] Departamento Nacional de Obras Contra as Secas - DNOCS se constitui na mais antiga instituição federal com atuação no Nordeste." Sobre essa instituição, a página do DNOCS disponibiliza informações sobre sua história e legislação em: < https://www2.dnocs.gov.br/historia > Acesso em: 10 set. 2018.

8 "A Superintendência do Desenvolvimento do Nordeste, criada pela Lei no 3.692, de 15 de dezembro de 1959, foi uma forma de intervenção do Estado no Nordeste, com o objetivo de promover e coordenar o desenvolvimento da região. Sua instituição envolveu, antes de mais nada, a definição do espaço que seria compreendido como Nordeste e passaria a ser objeto da ação governamental: os estados do Maranhão, Piauí, Ceará, Rio Grande do Norte, Paraíba, Pernambuco, Alagoas, Sergipe, Bahia e parte de Minas Gerais." Disponível em: < https://cpdoc.fgv.br/producao/dossies/JK/artigos/Economia/Sudene > Acesso em: 10 set. 2018. 


\section{Politicas públicas no combate à seca}

Para combater os terríveis efeitos da seca, se criam órgãos que visam ajudar as populações que são atingidas a partir da seca de 1877. As políticas públicas são pensadas para amenizar os efeitos destruidores e o flagelo da seca para que não voltassem a ocorrer as atrocidades daquele período. Dessa maneira, se criam propostas e órgãos com a função de estudar e minorar os efeitos nas populações sertanejas das temporadas de estiagem, como nos aponta no seu trabalho já citado, Frederico de Castro Neves:

Em 1909, o governo cria o IOCS (Inspetoria de Obras Contra a Seca) que, apesar de um órgão federal, é imediatamente destinado a uma atuação no semi-árido. Experiências anteriores de acumulação de água formavam a base técnica dessa nova instituição, como a construção do açude Cedro, em Quixadá. Do ponto de vista programático a atuação do IOCS era orientada pela concepção de que a seca - como fenômeno climático de irregularidades de chuvas, o que dificultava a agricultura e o abastecimento das cidades - deveria ser combatida pela criação de um sistema de barragens, açudes e poços que pudesse acumular a agua em tempos de chuva para ser usada em tempos de escassez. Essa concepção ficou conhecida como "solução hidráulica", pois concentrava todas as atenções nos métodos técnicos de estudos de solo e construção de reservatórios d'agua9.

O projeto acima é ligado ao sistema de "emergências", como ficaram conhecidas as frentes de trabalho que faziam parte do projeto de combate à seca, que usava o trabalho dos retirantes nas construções de obras de estradas, açudes, barragens, ligados a outra forma de impedir a migração dos sobreviventes para a capital do Ceará, criando-se os chamados "campos de concentração", que serão as ferramentas de organização do trabalho dos que fugiam do sol implacável.

Assim, passo a passo são criados instrumentos de combate aos efeitos destruidores da seca. Todavia, o que se pode perceber é que os sistemas são adaptados a servir a uma minoria, que ganha com a chegada desses projetos, deixando as populações à margem de toda sorte de exploração e de serem lesadas pelos que dominavam economicamente as regiões. Podemos ver isso na fala do senhor Vicente Rodrigues de Oliveira, pescador e morador da cidade de Varjota, que passou sua vida nas margens do famoso Açude Araras, que também foi construído nas frentes emergenciais da década de 1950. Aos sessenta anos de idade, nos fala de suas memórias durante os fenômenos climáticos da década de 1980 no município:

9 NEVES, Frederico de Castro, Op. cit., p. 86. 
Naquela época tudo era difícil, sabe? Só mandava quem era rico, os coronel. Eu não sofri tanto não, tinha minhas vazantes e meu gado e dava pra ir me mexendo, mas vi muita gente sofrendo, passando fome, tinha os serviços, mas você tinha que ser apontado por alguém, como tinha conhecidos eu pedia serviço pros amigos, mas quem não tinha ninguém assim grande que pudesse indicar ou morria de fome ou ia embora. O dinheiro vinha pras obras, aí um dono de terra passava por exemplo a estrada dentro da propriedade dele, aí ele ficava com o dinheiro e com a estrada e pagava uma miséria pro povo, mas era o que tinha e nem adiantava reclamar ${ }^{10}$.

O relato acima não é único, outras pessoas que presenciaram esse período apontam para cenários parecidos em que a força de trabalho dos sobreviventes e os recursos vindos para combater a seca ficavam nas mãos de uma minoria, restando às massas o trabalho compulsório e quase escravizado. Esse aspecto é ilustrado com os estudos de Frederico de Castro Neves que nos diz a respeito da criação da SUDENE e seu uso inapropriado:

\begin{abstract}
Esse foi o caminho para a incorporação da SUDENE ao circuito de poder estabelecido pelo modelo paternalista: ao serem definidas as "áreas criticas", os recursos eram destinados diretamente aos municípios, a fundo perdido, sob o controle das prefeituras. As obras beneficiam as propriedades, com mão-de-obra quase gratuita dos retirantes, passando a fazer parte das relações econômicas e políticas do semiárido. Assim, novamente as lideranças locais e tradicionais, praticando uma política paternalista e tradicional, conseguem controlar os órgãos de planejamento - instituições modelares de uma política representativa moderna ${ }^{11}$.
\end{abstract}

A partir das duas colocações, de que na região onde hoje se localiza Varjota havia uma distinção, não eram mais as levas migratórias, como aponta o autor, que são condicionadas a essas práticas, mas os moradores do território. Varjota é um município relativamente novo, seu processo de emancipação do município de Reriutaba se dá em 1986, mas se forma num período conturbado politicamente, climaticamente, enfrentando resquícios das grandes enchentes de 1982 e a seca do final da década, junto à formação enquanto município no período chamado de redemocratização, nos quais os órgãos públicos e todo o sistema organizacional do país estavam em uma mudança frenética e se desenvolvendo para atingir os fins democráticos. $\mathrm{E}$ isso vai interferir em como os cidadãos são expostos durante as instabilidades da década de 1980.

10 Vicente Rodrigues de Oliveira. 60 anos, pescador. Entrevista realizada pela autora em 13 de setembro de 2018. Varjota-CE.

11 NEVES, Frederico de Castro, Op. cit., p. 89. 
Outro ponto é a identificação do Nordeste como uma região de predominância masculina, uma sociedade construída pelo patriarcado. Nossa preocupação é compreender como essa política de criação identitária vai se constituir nas políticas de combate à seca interferindo na vida de outra parcela da população vítima da seca. Passaremos agora a estudar como as mulheres eram pensadas nesse cenário de combate à fome, à miséria e ao flagelo da estiagem, além de como as políticas públicas pensavam esse outro sujeito, ou mesmo se pensavam. Nos preocuparemos agora em como sobreviviam as mulheres do Nordeste, focando nas do município de Varjota nas épocas de pouca atividade pluvial.

\section{O papel feminino nas politicas públicas}

Estudiosos como Durval Muniz, já citado anteriormente, em seu trabalho A Invenção do Nordeste e outras artes, aponta que ao se criar o termo "nordestino" se busca associar a ele uma identidade viril, fálica. No Nordeste é assim, o homem nasce predestinado a exercer sua masculinidade e essa forma de pensar vai se firmar cada vez mais na literatura, nas músicas, nas artes, no cinema, nas produções populares. Cria-se, portanto, uma sociedade extremamente patriarcal, voltada para a supremacia masculina, que representa o contrário das posturas que geralmente se associam ao feminino, que, por sua vez, vai se associar à submissão do Nordeste às demais regiões, como se fosse reflexo de uma conduta feminina, fadada à inferioridade. Essa construção pode ser percebida, de certo modo, nas políticas e nas atitudes de combate à seca. As políticas pensadas para combater o flagelo das estiagens não são pensadas a princípio para englobar as mulheres.

As frentes de trabalho são primordialmente masculinas. Sabemos que a adoção de campos de concentração na seca de 1932 como política de combate à seca organiza as frentes de trabalho: enquanto os homens vão trabalhar nas construções, as mulheres se encarregam das atividades de conservação dos ambientes de convivência, cuidando das tarefas de limpeza e organização. A questão da moralidade se fez presente na construção de igrejas nos campos, a fim de educar os corpos para que não houvesse descumprimento dos mandamentos. É o que nos diz a historiadora Kênia Sousa Rios:

A preocupação dos vigias era acima de tudo com a moralidade e a decência. Para a realização de um projeto assistencial, disciplinador e civilizador, era necessária uma vigilância redobrada sobre o comportamento sexual dos flagelados. Afinal, a imagem desse tipo de projeto ficaria bastante comprometida se os considerados "atos indecorosos" chegassem a se impor entre os retirantes. Desse modo, "os casebres eram divididos em 
um pavilhão para os homens solteiros e outro para as viúvas e as famílias" (Correio do Ceará,06/05/1932) [...] Em todos os campos de concentração, foram erguidas capelas, que, além de abrigar as orações e alimentar a fé dos flagelados, eram utilizadas para reforçar a vigilância sobre os corpos. No campo de concentração no Ipu, o vigário Gonçalo Lima celebrava missas, casamentos e batizados semanalmente. Ao expor o assunto, o Jornal da Semana (05/11/1932) fez um comentário que pode ser visto como um significativo indício do imaginário das classes dominantes em torno da vida moral dos retirantes: "em um meio tão propício à corrupção dos costumes somente a ação constante do vigário e dos catequistas poderia manter a moralidade" 12 .

Essa moralidade se mantem no imaginário nordestino. Passadas as secas, algumas pessoas retornam aos seus lugares de origem ou se destinam a outros e essas experiências vão tornando as culturas híbridas e os valores vão sendo imbricados nas formações sociais. Atrelado a esse pensamento, temos a constituição do "nordestino" que se cria nesse meio civilizatório. Assim, as mulheres são condicionadas a inferioridade por não terem a característica máxima, o falo, ou seja, não gozam de virilidade, cabendo-lhes a inferioridade. Não se está, contudo, afirmando que a sociedade nordestina anterior a essa constituição identitária não fosse patriarcal, o que estamos apontando é que ao se cunhar essa descrição ao sertanejo, o patriarcalismo se torna poderoso e as mulheres são inseridas de forma diferenciada nas políticas de combate à seca.

Nas secas seguintes a realidade vai se transformando, as ondas migratórias já não são tão fortes e as políticas já conseguem, até certo modo, assegurar as permanências das populações em suas áreas interioranas. Assim, entre os períodos de estiagem há os chuvosos que garantem ao sertanejo certa confiabilidade. Durante a seca, as obras governamentais passaram a ser colocadas em prática nas chamadas "frentes de emergência" e se tornaram o salva-vidas das populações durante a pouca atividade fluvial. Construções de açudes, estradas e poços mantiveram os cearenses dentro de suas regiões, sendo muito menor o índice migratório em relação às ondas maciças durante as secas de 1877,1915 e 1932. As mulheres são contempladas indiretamente nessas políticas enquanto seus maridos, pais e irmãos trabalham. Porém, a população feminina continua condicionada à inferioridade diante do falo. Os programas não são pensados para englobar mulheres, exercendo muitas vezes atividades iguais aos homens. Exaustivos, não abrem espaço para que elas consigam uma fuga do patriarcado, são inúmeros os depoimentos de

12 RIOS, Kênia Sousa. Campos de Concentração no Ceará: isolamento e poder na seca de 1932. $2^{\mathrm{a}}$ ed. Fortaleza, Museu do Ceará, 2006, p. 58. 
mulheres que buscam no anonimato do governo e da moralidade da igreja, meios de sobreviver ao clima e a vida seca do sertão.

\section{As mulheres de Varjota nos períodos de seca}

Diante de um cenário desolador, a seca bate à porta, os homens saem em busca de trabalho, geralmente mal remunerados nas frentes de serviço, com uma família numerosa, e o que ganham quase não dar para manter o lar. Nessa realidade, as mulheres que ficavam em casa assistiam seus filhos padecerem pela fome, as doenças, que, acirradas pela ausência de nutrientes, fragilizavam o organismo, e então uma gripe poderia ser letal. Fazendo o uso da Oralidade nos voltaremos a depoimentos de pessoas que presenciaram o fenômeno da seca em diferentes momentos, como habitantes da região onde hoje se configura Varjota.

Para que consigamos adentrar esse universo da sobrevivência nos períodos de seca, contaremos com o apoio da Historia Oral ${ }^{13}$ para nos aproximarmos das experiências de alguns cidadãos que habitam a região hoje entendida como Varjota. Começamos com o depoimento de uma senhora que vivenciou as grandes secas de 1958 e da década de 1980. Então, esse é o cenário em que viveu e assistiu outras mulheres viverem, Francisca Arcelino do Nascimento, hoje com 83 anos, durante a seca de 1958, quando nos conta suas memórias diante da realidade e das dificuldades, lembrando o tempo sobre o qual demonstra pesar:

Na seca do 58 as coisas era difícil. Meu marido, que Deus lhe guarde, não era muito de ficar em casa, ele ganhava o mundo e a gente ficava, os meninos era pequenos sabe? Não tinha como levar não. Ele saía sem prazo pra voltar e eu ficava. No 58 foi seco e ele já não vinha pra casa há um tempo e eu correndo né? Atrás de ganhar pelo menos a comida dos meu fie. Num tinha nada em casa, a alcova tava vazia, e Antônia, a maior, eu sabia que podia viver, mas o Raimundo, o mais novo, eu não achava que vingava não, era muita fome. Ai um dia eu dei a última comida que tinha pra eles, era farinha molhada com rapadura, era o que tinha, e saí com fome pra ver se conseguia algum trabai em troca de comida. Ai, fui na casa de um conhecido do meu pai pedir farinha, rapadura ou feijão, pra pagar com tra-

13 "Ao recorrer à História Oral, é preciso entendê-la numa perspectiva que vai além do relato de fatos: é sua maneira de se chegar ao conhecimento de fatos vivenciados num dado momento histórico em que somente documentos escritos não poderiam revelar por si só todos os sentidos circulantes num determinado meio social". In: MENEGOLO, Elizabeth |D. da C. W; CARDOSO; Cancionila J.; MENEGOLO, Leandro Wallace. O Uso da Historia Oral como instrumento de pesquisa sobre o ensino da produção textual. Disponível em: < http://pepsic.bvsalud.org/pdf/cc/v9/v9a02.pdf >. Acesso em: 12 out. 2018. 
balho quando fosse tempo, disse minha situação e que a gente ia morrer de fome se continuasse assim, mas a dona da casa era daquelas de mão fechada, sabe? E disse que se desse comida ia ter mais gente chorando e, olhando na minha cara, disse que era melhor que só um chorasse, porque não sabia quando ia chover, tava guardando as coisas. Eu num sabia mais o que fazer, ai eu disse que tava querendo pagar com trabai, mas que num ia deixar meus fie morrer de fome e quando passasse as criação dele lá por casa eu ia matar e vender pra alimentar os meus fie. O dono da casa quando ouviu não acreditou, ai mandou ela pegar umas coisa pra eu levar, ele disse que se uma filha do Antônio Arcelino tava falando em roubar era porque a coisa tava séria, aí ela me deu, umas não foi gostando não, dois dias depois minha irmã chegou com um jumento com a cangaia cheia de coisa que meu pai tinha mandado porque o homem tinha contato a ele o que eu fiz. Quando choveu fui lá e paguei as coisa que ele tinha me dado ${ }^{14}$.

O relato acima descrito se passa durante a temível seca de 1958, quando as fontes de sobrevivência ficaram muito escassas. É desse período, por exemplo, a construção do açude Araras, que trouxe inúmeros retirantes em busca de trabalho e sobrevivência nas frentes de emergência, como ficaram conhecidas as obras públicas, visto que a seca dizimara lavouras e rebanhos. As obras públicas contavam com a mão de obra sobrevivente das secas, mas conta com a característica de ser uma política voltada aos homens e não contava com o trabalho feminino. Às mulheres era designada a espera, que seus maridos voltassem para casa com o ordenado, para alimentar com o pouco dinheiro que ganhavam, pelo menos os filhos. Mas, as mudanças sociais que caminhavam no mundo chegaram ao sertão também. Nos relatos da seca de 1989 já temos uma mudança, apontando para a presença feminina que já faziam parte na mão de obra nas "emergências". Podemos observar este aspecto na fala de Maria Zélia de Sousa que, embora tendo sete anos à época, assistiu sua mãe trabalhar numa das frentes emergenciais:

Minha mãe me levava com ela pro trabalho, não tinha com quem me deixar, mulher solteira com filho sofria muito, e minha mãe também sofreu, ela me levava e eu era criança, via o povo levando carrinho de mão cheio de pedra ou barro, pra construir o poço, a mãe, como era jeitosa na cozinha, ficava com o trabalho de casa. Ela lavava roupa, enchia os pote, varria os terreiros, mas eram grande, uma imensidão só. $\mathrm{Eu}$, como era pequena, não trabalhava, mas tinha outros que trabalhavam sim, criança, adolescente, principalmente os menino, que começavam cedo nas emergências. 89 foi seco,

${ }_{14}$ Francisca Arcelino do Nascimento, 84 anos, aposentada. Entrevista realizada pela autora em 20 de agosto de 2018. Varjota-CE. 
até tinha o açude, mas nós não morava tão perto assim e as coisas era difícil, era só farinha e feijão mesmo, quando tinha, e feijão d'agua no sal mesmo, e a mãe ia todos os dias, mas as outras mulheres, ia era carregar pedra também, tirar as raiz, essas coisa. E não tinha diferença não, a tarefa, como era chamado, era mesma a dos homens, às vezes se você tinha parente homem lá trabalhando, eles terminavam a dele e ia ajudar, mas se não, só saía quando terminava, e as mulher que não tinha marido sofria, por que eram mal vistas, se dizia que não tinha dono, ai geralmente ninguém ajudava elas, porque ficava mal visto quem andava com elas, a mãe era mãe solteira, mas tinha muitos conhecidos, por isso não ia diretamente pras frente carregar barro e serviço dos homens ${ }^{15}$.

A partir de ambos os relatos, podemos ver que algumas coisas mudaram entre 1958 e 1989. O mundo passou por significativas mudanças e as levas migratórias, os fluxos entre o interior e as demais áreas também pode ser refletida, ainda que de maneira tímida, no mundo dos que viviam na escassez. Contudo, o machismo era a regra, e mudara seu foco, porém se mantinha. Ser mulher nesse cenário já era difícil, quando fugia à regra, então, se tornava uma tarefa árdua e muitas mulheres eram vítimas da misoginia e dos preconceitos que cercavam as mentalidades do interior nordestino. Os espaços que passaram a ser ocupados pelas mulheres não garantiam sua proteção. Eram muito mal vistas. A associação dessas mulheres à submissão adentrava nestes espaços e criava cenários propícios a situações de desrespeito, assédio e menosprezo, e isso, inúmeras vezes, incluíam até a própria família e, até mesmo, outras mulheres.

\section{À margem dos planos públicos: a sobrevivência feminina}

Com o desrespeito, a baixa remuneração e as humilhações nas frentes emergenciais, as mulheres acabaram encontrando no ambiente machista algumas possibilidades de ganharem uma renda que as ajudassem a sobreviver na escassez. As que tinham maridos precisavam ajudá-los devido a pouca renda que geravam os trabalhos nas emergências. As solteiras, que eram mal vistas nestes espaços de trabalho, precisavam sobreviver, visto que, geralmente, eram deixadas de lado até pela própria família, com filhos pequenos. Mães solteiras, separadas e viúvas tinham de lutar pela sua sobrevivência. Deste modo, como as obras emergenciais vinham para beneficiar os potentados locais, as construções se davam em suas propriedades e as mulheres geralmente trabalhavam para as esposas destes privilegiados em troca de comida ou dinheiro pelas tarefas executadas, como carregar água (já que não havia água encanada), lavar roupa, varrer os terreiros e fazer os almoços dos trabalhadores.

15 Maria Zélia de Sousa. 36anos, Domestica. Entrevista concedida a autora dia 19 de agosto de 2018. 
Outro modo de adquirir renda era o trabalho com a carnaúba, que feito em algumas etapas inseria o trabalho feminino. Abundante no Ceará, da carnaúba não se desperdiça nada e a sua utilização em diversos meios requeria etapas de trabalho. O mais famoso produto no interior de Varjota era e ainda é o "chapéu de palha", um produto artesanal, que não é usado como vestimenta, sendo feito menor e sem acabamentos, é vendido para outros estados usados no plantio. Assim, essa forma de artesanato ajudou inúmeras famílias, seja complementando a renda ou sendo uma fonte exclusiva de sobrevivência quando não havia espaços em outras áreas. Sobre isso nos fala dona Maria Zélia de Sousa novamente:

Eu faço chapéu desde criança, minha mãe fazia, minha avó fazia, e as mulheres tudo de onde eu morava. Era pouco o ganho, mas era o que tinha. Eu lembro que trabalhei duas semanas fazendo chapéu pra comprar meu primeiro xampu, a gente tinha que se virar, sabe? Tudo era difícil, aí o chapéu ajudava demais a gente. Eu lembro que quando a televisão chegou, era uma novidade, só os ricos tinha, aí se juntava as mulher com os saco de chapéu e ia pra casa da mulher que tinha televisão, e naquela época, nem tinha energia, só em Varjota, era na bateria. Aí no intervalo ela desligava pra economizar, às vezes, quando ligava de novo, já tinha passado um bom pedaço da novela. Sei que quando a gente voltava, vinha com aqueles tudo pronto ${ }^{16}$.

Outras narrativas seguem esse mesmo curso. As mulheres da palha ganhavam seu dinheiro às margens dos planos oficiais nas épocas de seca. Essa atividade, no entanto, não era a única. $O$ riscar da palha, a fabricação de vassouras, a colheita da cera, tudo isso era remunerado, e ainda que pouco, ajudava na aquisição de renda e significavam possibilidade de sobrevivência nos períodos mais drásticos. A palha, assim, surge nesse cenário machista e pobre no interior de Varjota e passa a simbolizar não apenas aquisição de dinheiro, mas uma fuga da seca e a difícil vida feminina que não era contemplada pelo poder público.

\section{Considerações finais}

No Nordeste se sabe que mesmo em anos de chuva, o período de agosto a dezembro costuma ser seco e escasso. Com o passar do inverno, as águas se distanciam e então se tem uma luta pela manutenção da vida até que as nuvens carregadas voltem aos céus do sertão. A ausência da chuva tornava calamitosa a situação do nordestino, que via o gado, a colheita e, inúmeras vezes, pessoas sucumbirem diante da ameaça dos céus. O sol implacável tragava toda a vida e restavam poucas possibilidades ao sertanejo, e ainda menos para as mulheres desse ambiente. Apesar das políticas públicas que tinham

16 Maria Zelia de Sousa. Entrevista já citada. 
como missão combater esses males, geralmente eram usadas para favorecer ainda mais os potentados, deixando os pobres na miséria e no trabalho quase escravo. As mulheres, como vimos, que ficavam às margens dessas políticas, sofriam ainda mais pelas imposições de uma sociedade machista e misógina que as cercava.

Desse modo, numa fuga do mundo criado para o falo, as mulheres encontraram atividades remuneradas que as ajudaram a sobreviver com seus filhos nesse cenário de escassez e sofrimento. $\mathrm{O}$ artesanato da palha de carnaúba surge, assim, como um meio de amenizar essas problemáticas. Os serviços informais para a casa dos potentados também ajudaram de alguma forma.

Sem dúvidas, há muito que se pesquisar sobre a temática; as narrativas são inúmeras e aos pesquisadores que se propõem a estudar o tema, torna-se imprescindível se voltar à oralidade e à memória dos que presenciaram as secas em nosso foco, as sucessivas que marcaram a década de 1980 do século $\mathrm{XX}$ e seus efeitos a partir das organizações sociais dispostas naquele meio. 



\title{
3. Os bastidores da seca: a exploração dos trabalhadores nas frentes de serviço do Açude Araras, Varjota-CE (1951-1958)
}

\author{
Letícia Rodrigues Gonçalves ${ }^{1}$
}

\section{Introdução}

Localizado na cidade conhecida atualmente como Varjota, no Estado do Ceará, o Açude Araras foi construído a partir de políticas públicas com o intuito de diminuir os efeitos causados pelas estiagens inerentes ao clima semiárido na região Nordeste. Porém, mais que projetos e cotidiano de trabalho, a grandeza de suas águas escondem histórias amargas que são lembradas até os dias de hoje pelos que participaram desse processo. Nesse sentido, nosso objetivo ao longo deste texto é analisar algumas interpretações que, intencionalmente ou não, são deixadas em último plano. Buscamos investigar vertentes que comumente são deixadas de lado, não por serem irrelevantes, mas por fazerem parte de meios que, de acordo com certas visões, não justificaram os fins. Para tanto, sendo mais específicos em nossa pesquisa, investigaremos a possibilidade de uma exploração da força de trabalho de homens e mulheres que atuaram nas frentes de serviço do açude. Percebendo uma visão intrínseca dessa perspectiva de estudo aos bastidores dessa construção, tentaremos, à luz de estudos desenvolvidos por Castro (2011), Neves (2000), Filho e Souza (1988), entre outros, analisar e refletir sobre algumas memórias e escritos que fazem parte dessa discussão. Dessa forma, poderemos mostrar outros protagonistas dessa história - homens, mulheres e crianças que enfrentaram adversidades não só climáticas, mas notadamente humanas na esperança de alcançar dias melhores.

Como se sabe, o Nordeste não é único lugar do Brasil que sofre com a carência de chuvas. No entanto, é o que padece mais com instabilidades e insuficiências da estação chuvosa. Localizado "quase todo no interior do espaço que se costuma denominar de 'polígono das secas"'2, o Nordeste, em especial a extensão de terra que hoje conhecemos por Ceará, ao longo do tempo sofreu com profundas estiagens provocadas pelas peculiaridades regionais.

Licencianda em História pela Universidade Estadual Vale do Acaraú-UVA. Bolsista PIBIC/CNPq. let. rg27@gmail.com

NEVES, Frederico de Castro. A seca na história do Ceará. In: SOUZA, Simone de. (Org.) Uma nova história do Ceará. Fortaleza: Fundação Demócrito Rocha, 2000, p. 76. 
As dificuldades para sobreviver com a amarga irregularidade de chuvas inerente ao clima semiárido era uma realidade. As consequências do déficit de água apresentaram em diversos momentos da história um quadro assustador de migrações desenfreadas, fome, sede, miséria, doenças etc. Porém, a fé dos sertanejos, pulsada por um desafio diário de lutas e coragem, também era real. Resistiam não só aos episódios causados pela natureza, mas também, e principalmente, à ação humana. Afinal, o fenômeno da seca não é um caso isolado, um demônio provocador de todo mal, sua ação só foi tão devastadora no aspecto humano, inicialmente pela falta e posteriormente pela precarização do trabalho propiciado pelas políticas públicas implantadas pelo governo.

Muitas são as datas marcadas na história com o símbolo da seca. Com ela acompanharam a sede, a fome, as retiradas, a morte, dentre outras mazelas. Existem muitas vertentes a se pesquisar, no entanto, a trajetória que escolhemos seguir começará pelos anos mais relevantes da nossa pesquisa. Ressaltaremos as datas de 1877 e 1915, pois são cruciais para entendermos a seca como um problema precisando formular estratégias para minimizar seus efeitos. Não esqueçamos igualmente 1953 a 1958, anos em que foram realizadas as obras do Açude Araras.

Antes de continuarmos, importa fazer uma ressalva. Não é nosso objetivo 34 aqui analisar o próprio fenômeno natural da seca, mas seu contexto social, ou seja, a identificação das consequências para os moradores do semiárido, bem como as dificuldades que muitos tiveram que passar para usufruir das políticas públicas, como, por exemplo, o uso da mão de obra dos miseráveis sentenciados pela fome, vítimas em potencial das circunstâncias que os levaram a tal situação. Sabemos que várias construções governamentais ajudaram famílias e municípios inteiros a enfrentarem os períodos de estiagem. Muitos sentem na pele até hoje os benefícios dessas ações. Contudo, ainda existem aqueles que não conheceram várias intencionalidades imbricadas nesse processo e, pior ainda, o preço que ela trouxe para uma grande parcela da população.

\section{A seca no Ceará: a identificação de um problema}

Através das suas ações mais acentuadas que ecoam, mesmo que modestamente, até os dias de hoje, os períodos de seca mais conhecidos na historiografia foram registrados nos anos de 1877 e 1915. Porém, a falta de chuvas nessa região já existia há muito tempo, mostrando que estes não foram anos isolados da nossa história, uma vez que: 
[...] Os primeiros colonizadores, pouco adaptados ao clima, viam-se em dificuldades quando ousavam atravessar o sertão ${ }^{3}$ em épocas de poucas chuvas.

Sabendo disso, voltamos para os anos citados acima, especialmente 1877, já que é a partir dele que o governo brasileiro começou a lançar olhares de preocupação para a região semiárida. No entanto, essa preocupação não se ligava exatamente à vulnerabilidade do povo ao fator climático, mas sim pela quebra do ritmo do ciclo econômico desenvolvido tanto pela produção algodoeira como pela criação de gado.

Por isso, 1877 se tornou um marco na compreensão do problema da seca [...] Neste momento, a irregularidade de chuvas deixa de ser "apenas" uma questão climática para se tornar uma questão social, que a todos afeta e que o Estado brasileiro não poderá mais ignorar ${ }^{5}$.

Ou seja, o Nordeste sempre sofreu com a seca, algumas vezes mais, outras menos, mas de maneira geral ela sempre esteve presente. No entanto, no instante em que atinge a economia do Estado brasileiro, a escassez de chuvas deixa de ser "apenas" uma "questão climática" e passa a afetar a "todos". Nesse sentido, apesar das reais intenções governamentais, é a partir desse momento que a seca passa a ser vista e enfrentada como um problema social.

A manutenção da produção para subsistência estava passando por um processo de mudança. Inseridos na economia de mercado, a seca mostrara o despreparo de governantes e governados na lida não apenas com a nova "ordem", mas com a antiga também. Questões econômicas e sociais começaram a quebrar a barreira entre o micro e o macro. Sempre ignorados, os problemas vivenciados há muito tempo por minorias chegaram naquele momento a fazer parte do cotidiano das maiorias, causando um desconforto digno de intervenções governamentais.

Nessas circunstâncias, quem mais sofria com as consequências desse despreparo era a população. A seca não esperava e não dava uma trégua. Faltando o básico para viver não restava outra alternativa senão iniciar a saga dos retirantes. Homens, mulheres e crianças, famílias inteiras eram obrigadas a sair de seus lares e tentar a sorte nas grandes cidades, enfrentando todas as adversidades possíveis pelo caminho.

O termo "sertão" empregado nessa citação era entendido na época como uma porção de terra afastada do litoral.

4 NEVES, Frederico de Castro. A seca na história do Ceará. In: SOUZA, Simone de. (Org.), Op. cit., p. 77.

5 Idem, p. 80. 
As localidades eminentemente despreparadas para receber as levas de famintos recém-chegados do interior entregavam-se ao caos. Fortaleza, por exemplo, que iniciara seu processo de embelezamento e mudanças "civilizatórias" foi influenciado pelo contexto europeu da Belle Époque (belos tempos) e sofreu sérios transtornos:

\begin{abstract}
A devastadora seca de 1877-1879, porém interrompeu temporariamente esse fluxo modernizador que instaurava na cidade além de desestabilizar a economia cearense e provocar intenso êxodo rural para a capital, a longa estiagem possibilitou a propagação de uma fulminante epidemia de varíola vitimando mais da metade dos 100 mil retirantes amontoados em abarracamentos providenciados pelo governo na periferia de Fortaleza ${ }^{6}$.
\end{abstract}

A capital cearense se reorganizou, mas não aprendeu. De nada serviram as sequelas deixadas pela seca de 1877. A falta de medidas preventivas ou assistencialistas realmente efetivas não impediu que o mesmo cenário acontecesse novamente. O ano de 1915 chegou com outra porção de famintos fugidos da estiagem. Contudo, com a cidade mais modernizada e com a experiência da seca passada, estratégias foram criadas para que os retirantes não invadissem a cidade e entrasse em contato com as pessoas, especialmente aquelas de nível social alto. Assim, o governo optou por criar o primeiro "Campo de Concentração" do estado no Alagadiço, situado a oeste da capital. As pessoas comumente apelidavam tal lugar de "Currais do Governo", por ser basicamente cercado por arames farpados e servirem "rações" para a alimentação dos miseráveis, que não cessavam de chegar. Estima-se que foram "abrigadas" cerca de oito mil pessoas neste Campo.

Exemplos da seca de 1915 mostram um pouco das mazelas que os retirantes passaram. Os que conseguiam chegar ao seu destino, pouco a pouco se amontoavam no Campo. Vejamos neste momento, através da fala de Conceição, na narrativa do romance O Quinze, de Rachel de Queiroz, como aparentavam:

Quando transpôs o portão do Campo, e se encostou a um poste, respirou mais aliviada. Mas, mesmo de fora, que mau cheiro se sentia! Através da cerca de arame, apareciam-lhe os ranchos disseminados ao acaso. Até a miséria tem fantasia e criara ali os gêneros de habitação mais bizarros ${ }^{7}$. 
Importa dizer que o romance regionalista citado traz no seu contexto social elementos históricos que pertenceram a um tempo e espaço existentes. O Quinze, dessa maneira, nos mostra por meio de personagens fictícios situações que muitos retirantes reais vivenciaram durante a seca de 1915 no Ceará.

Observando o impacto da seca para a população percebemos que o fenômeno climático por si só não é detentor de toda a culpa. Por muito tempo ele foi o alvo de todas as mazelas do povo, no entanto, podemos ver que a falta de projetos governamentais contribuíram bastante nos resultados apresentados. Passemos agora para os momentos tardios e desumanos das políticas públicas.

\section{O caminhar do projeto das açudagens}

As primeiras tentativas de construir um plano para amenizar os efeitos da seca no Nordeste são observadas no final do século XIX. A necessidade veio por meio da devastadora seca de 1887 que pressionou as autoridades imperiais de então a tomarem partido na situação. Equipes de diversos pesquisadores baseados em modelos estrangeiros montavam projetos iniciais de implantação de açudes, barragens e poços que atendessem à carência da população sertaneja. Um marco deste momento foi a construção do açude Cedro, localizado em Quixadá-CE; suas obras foram iniciadas em 1890 e concluídas em 1906.

Porém, na prática, muitas tentativas do governo para amenizar os distúrbios provocados pela falta d'água não obtiveram grande sucesso, afinal isso nunca tinha sido feito antes, ou pelo menos não dessa maneira. Os projetos mal elaborados acabavam expondo uma desorganização muito grande por parte das autoridades. Desta maneira, era necessária organização, estabelecer departamentos exclusivos e com projetos sólidos para tratar tais assuntos.

Nesse sentido, em 1909, foi estabelecido o primeiro órgão com este intuito, a Inspetoria de Obras Contra as Secas (IOCS):

Do ponto de vista programático, a atuação do IOCS era orientada pela concepção de que a seca - como fenômeno climático de irregularidade de chuvas, o que dificultava a agricultura e o abastecimento das cidades - deveria ser combatida pela criação de um sistema de barragens, açudes e poços que pudesse acumular a água em tempos de chuva para ser usada em tempos de escassez. Esta solução ficou conhecida como "solução hidráulica”, pois concentrava todas as atenções nos métodos técnicos de estudo do solo e construção de reservatórios d'água ${ }^{8}$.

8 NEVES, Frederico de Castro, Op. cit., p. 86. 
Posteriormente, sendo mais especifico, em 1919, o IOCS passa a se chamar Inspetoria Federal de Obras Contra as Secas (IFOCS). A diferença não estava só no nome, este estava encarregado da implementação de outros tipos de infraestruturas além das açudagens. Foram agregadas as construções de estradas, campos de pouso, eletrificação etc.

E por último, em 1945 foi promovido, transformando-se em autarquia, sendo conhecido até os dias de hoje como Departamento Nacional de Obras Contra as Secas (DNOCS). Com tal departamento vieram, portanto, ainda mais tipos de construções, como por exemplo: ferrovias, rodovias, canais e especialmente outros açudes nos mais diversos locais do estado, inclusive o Araras, foco do nosso estudo.

\section{A exploração nas frentes de serviço}

O Açude Paulo Sarasate, mais conhecido como Açude Araras, fica localizado na cidade de Varjota-CE. Foi construído sobre o leito do Rio Acaraú entre os anos de 1951 a 1958, quando ainda pertencia ao município de Reriutaba-CE. Sob o comando do DNOCS, seu propósito era "fixar o homem no campo", ou seja, impedir novas migrações em momentos de grande estiagem.

Atualmente, além de ser um belo ponto turístico, é o quarto maior reservatório do estado do Ceará. Sua capacidade chaga aos 891 milhões de metros cúbicos de água, abastecendo os municípios de Varjota, Pires Ferreira, Hidrolândia e Santa Quitéria.

Contudo, o Açude Araras, que está em grande evidência hoje, não surgiu do nada e muito menos se fez sozinho. Por trás da grandeza de suas águas houve muito mais do que um simples cotidiano de trabalho. Miséria, sofrimento, fome e exploração fizeram parte do dia-a-dia dos trabalhadores que participaram de todo o processo de sua construção. Homens, mulheres e crianças participaram arduamente da construção do que chamamos peculiarmente de "mina de ouro do Nordeste", tudo para trazer o conforto e a segurança que temos hoje ao atravessarmos períodos de seca. No entanto, na maioria das vezes, tais feitos não recebem notoriedade, ou melhor, são intencionalmente esquecidos.

Os retirantes que migravam em busca de serviço nas barragens vinham dos mais diversos lugares. Sem perder a esperança em dias melhores, lutavam para sobreviver não somente ao fenômeno da natureza inerente ao seu clima, mas também à crueldade do governo com relação aos salários e as condições de trabalho impostas a eles: 
construídas durante as secas do Nordeste, somos propensos a esquecer as péssimas condições de trabalho e de salários ali praticados. Como já dissemos anteriormente, o salário que é pago nas frentes de trabalho sempre foi suficiente apenas para o trabalhador reproduzir a sua miséria. Chegado o inverno termina a seca, e tudo continua na mesma pobreza ${ }^{9}$.

Desde o início efetivo das obras do Açude Araras, a precariedade dos trabalhadores era gritante. Fome, doenças, alojamentos ruins, a falta de mantimentos e de dinheiro mostravam a real situação das frentes de serviço. Vivendo nessas condições, logo esses homens adquiriram um apelido bem peculiar.

Na metade do século XX, os trabalhadores das frentes de serviços das secas do Departamento Nacional de Obras Contra as Secas (DNOCS) já eram apelidados de "cassacos". Esse nome é dado a um animal feio e fedorento no Ceará, Pernambuco, Paraíba e outros estados nordestinos ${ }^{10}$.

Dentro de todos esses fatores já mencionados, os cassacos ainda:

[...] eram humilhados e viviam em condições de risco, mal remunerados e a mercê do jogo político como, por exemplo, o voto de cabresto (os que votavam eram obrigados a apoiar o partido da situação, caso contrário eram ameaçados de demissão) Devido aos destratos sociais a que eram submetidos, com a sigla DNOCS criaram a frase: Deus Não Ordena Cassaco Sofrer ${ }^{11}$. Mas, antes disso, eles usavam a frase: Sofre Cassaco Ordinário Nesse Departamento.

Sabemos que tal tratamento pode ser considerado como exploração do trabalho. Também sabemos que tal abuso pode ser exemplificado de várias maneiras possíveis. Contudo, neste momento, tentaremos explicar e comprovar que houve sim uma ação exploratória nas frentes de serviço, analisando um dos diversos posicionamentos impostos aos trabalhadores, a saber, a questão salarial. Estamos falando aqui de receber certa quantia de acordo com os serviços prestados pela força de trabalho. No entanto, como é possí-

FILHO, João Medeiros, SOUZA, Itamar de. A seca do Nordeste: um falso problema. Rio de Janeiro: Vozes, 1988, p. 69-70.

10 CASTRO, Lara de. "Cassacos": trabalho, cotidiano e conflitos nas frentes de serviço na Bahia e no Ceará (1945 - 1962) In: Anais do XXVI Simpósio Nacional de História - ANPUH. São Paulo. 2011, p. 01.

11 Ao longo da escrita, a autora informa que tal frase significa DNOCS, porém, de trás para frente, ou seja, SCOND. As duas frases foram tiradas de depoimentos obtidos, através do uso de História Oral, de alguns trabalhadores que participaram da construção do açude. FARIAS, Gilmara Rejane de. VARJOTARARAS. Sobral. Sobral Gráfica. 2010, p. 56. 
Nossa Gente,

Nossa História

o Ceará Republicano

vel saber o valor necessário que o trabalhador deve receber, uma vez que sua mão de obra não é uma mercadoria? No sentido usual da palavra ela não é, porém, normalmente é tida como tal a partir do momento em que se recebe por ela. Temos que saber que existem peculiaridades que determinam seu valor de maneira mais complexa, tanto em princípios como em especificidades de objetos, como roupas e alimentação por exemplo.

\begin{abstract}
Como valor, a força de trabalho representa apenas uma quantidade determinada do trabalho social médio nela objetivado [...]. Para sua manutenção, o indivíduo vivo necessita de certa quantidade de meios de subsistência. Assim, o tempo de trabalho necessário à produção da força de trabalho corresponde ao tempo de trabalho necessário à produção desses meios de subsistência, ou, dito de outro modo, o valor da força de trabalho é o valor dos meios de subsistência necessários à manutenção de seu possuidor ${ }^{12}$.
\end{abstract}

Desse modo, como o valor da força de trabalho é fixado? Segundo Marx, justamente pelo valor de todos os objetos básicos para suprir as necessidades do trabalhador em sua condição de vida. Somemos então o valor da comida, das roupas e calçados, produtos higiênicos, remédios e tudo mais que se faz necessário para sustentar o trabalhador, e o total determina o valor da sua mão de obra. Nesse sentido, "a quantidade dos meios de subsistência têm, portanto, de ser suficiente para manter o indivíduo trabalhador como tal em sua condição normal de vida”. Mas que normalidade é essa, como a determinamos? Há diversos tipos de trabalho, onde suas necessidades se distinguem por vários fatores. Existem "necessidades naturais, como alimentação, vestimenta, aquecimento, habitação etc.", que "são diferentes de acordo com o clima e outras peculiaridades naturais de um país" ${ }^{13}$. Então, deve ser levado em consideração atividades que gastam mais ou menos energia, tanto mental como braçal, o tempo que se gasta nesse esforço, as temperaturas, como a exposição em excesso ao calor ou ao frio, ou seja, há uma série de especificidades e necessidades para ambientes e serviços diferentes que devem ser levadas em consideração para a fixação de um salário no mínimo justo para o trabalhador.

Todo esse contexto serve para mostrar que o valor que o trabalhador necessitaria receber deveria pelo menos sustentá-lo de maneira satisfatória, mas o que acontecia nas frentes de serviço do Açude Araras era o contrário disso.

12 MARX, Karl. O Capital: O processo de produção do capital. Livro I, volume I. São Paulo: Nova Cultural, 1988 , p. 245.

13 Idem, p. $245-246$. 


\section{Notícias do cotidiano de trabalho}

Posto tudo isso, vejamos então algumas falas de pessoas que participaram do processo de construção do açude e o que alguns jornais da época falavam sobre sua situação em seu expediente.

O jornal Tribuna do Povo (MA), em sua edição de 1954, comunica sobre a II Conferência Nacional de Trabalhadores Agrícolas em São Paulo no ano anterior, onde conquistaram o salário mínimo. No entanto, algumas linhas abaixo também informam sobre a realidade dos trabalhadores do Açude Araras. "o salário-mínimo ainda não está sendo pago. Muitos patrões exigem mais de 10 horas de trabalho. A jornada chega a ser, por vezes, de 16 a 18 horas, como acontece no Açude Araras no Ceará" ${ }^{14}$.

Lembramos contextualmente que estamos na década de 1950 e a diretriz que estabeleceu a Consolidação das Leis do Trabalho (CLT) data de $1^{\circ}$ de maio de 1943. Sendo que as proteções ao trabalhador já estavam sendo colocadas em pauta desde o início do Governo Vargas, em 1930. Dentre as mais importantes ressaltamos o salário mínimo e a jornada de 8 horas de trabalho.

O jornal Imprensa Popular mostra em seu noticiário como estavam as condições da construção. As mortes, principalmente de crianças, são o destaque. Prestemos atenção primeiramente no título: "A custa de muita miséria está sendo construído o Açude Araras. Vinte e duas crianças nasceram na primeira semana de novembro e todas morreram de fome - Exploração do D.N.O.C.S.. E fala mais ao longo da notícia:

Na construção do açude de Araras, já chegaram a trabalhar cêrca de 7.630 trabalhadores, dos quais 90 por cento eram lavradores vítimas da sêca que assola o Nordeste. Hoje, êsse número foi reduzido para 5 ou 6 mil e a miséria e a fome se assenhoram completamente a situação. Quem entra em Araras, vindo de Reriutaba, o primeiro quadro que depara é a fila de latadas onde se abrigam os «cassacos»). São nessas latadas que habitam os trabalhadores do açude, alguns com famílias de doze e dezesseis pessoas ${ }^{15}$.

Avistamos aí as condições em que essas pessoas se encontravam. A miséria e a morte por desnutrição é mais que uma exploração, é uma verdadeira escravização disfarçada envolta de uma política pública tida como benevo-

14 Jornal Tribuna do Povo (MA), 7 de Agosto de 1954/Edição 00176, p. 3. Disponível em: http://memoria.bn.br

15 Jornal Imprensa Popular (RJ) 17 de novembro de 1953/Edição 01655, p. 4. Disponível em: http:// memoria.bn.br. É importante frisar que as palavras utilizadas foram mantidas fielmente à escrita da época, até mesmo os erros gramaticais. 
lente. Para piorar o cenário, os engenheiros e mestres de obras que estavam à frente do serviço, além de fornecedores de mercadorias buscavam de toda maneira lucrar em cima do trabalho dos cassacos.

\begin{abstract}
Além do trabalho verdadeiramente escravo e dos baixíssimos salários, nem mesmo a importância que lhes cabe pelo seu esforço, os operários têm direito de receber, isto porque o D.N.O.C.S., entra em conjunto com os fornecedores, para que estes se encarreguem do assalto aos miseráveis salários dos trabalhadores. Como é notório o pagamento se atrase durante meses seguidos. Então os «barracões» fornecem aos operários alimentos pelo duplo ou triplo do preço, razão pela qual no dia do pagamento somente recebiam «vales» enquanto o dinheiro vai para as mãos dos fornecedores ${ }^{16}$.
\end{abstract}

Alguns anos se passaram, estamos agora em 1958, período final das obras, e as circunstâncias não mudaram em nada:

Na construção do Açude Araras, formigueiros humanos abrem estradas e fazem jus a uma diária de 40 cruzeiros. Entretanto, até agora, os trabalhadores não viram a cor do dinheiro. Recebem pagamento em gêneros. Os fornecedores enriquecem a custa da fome e da desorganização administrativa do governo. A "diária" de 40 cruzeiros dá, apenas, para o trabalhador com a família alimentar-se exclusivamente de feijão e só de feijão. Crianças e adultos não comem outra coisa, nem dispõem de qualquer dinheiro para roupas rudimentares ${ }^{17}$.

Outra manchete do jornal Correio da Manhã fala de uma exploração ainda pior, deixando bem destacada logo em seu título: "Parlamentares nordestinos podem, mas não querem vencer a seca - O governo está explorando mulheres e crianças" e continua no decorrer da informação:

Enquanto isso - uma hora de avião, no açude de Araras, por exemplo - deparamos com menores franzinos, um até mesmo sem um dos braços, empunhando enxadas e picaretas, castigados pelo sol abrasador tocando as obras do governo. A desorganização é completa, total, absoluta, invertendo-se inclusive $\mathrm{o}$ adequamento das idades ${ }^{18}$.

16 Jornal Imprensa Popular (RJ) 17 de novembro de 1953/Edição 01655, p. 4. Disponível em: http:// memoria.bn.br

17 Jornal Correio da Manhã (RJ), 11 de maio de 1958/Edição 19975, p. 12. Disponível em: http://memoria.bn.br

18 Jornal Correio da Manha (RJ) 13 de maio de 1958/Edição 19976, p. 16. Disponível em: http://memoria.bn.br 
Vemos então, um aproveitamento exploratório da mão de obra de toda a família, onde até as crianças participavam. Por isso também, a taxa de mortalidade era maior entre elas. Doenças, miséria, fome junto com o esforço braçal contínuo, formavam uma soma com um resultado fatal.

\section{Considerações finais}

Depois de observadas bibliografia e manchetes jornalísticas da época em questão conseguimos encontrar, por diversos momentos, fatores que indicam que houve uma grande exploração, senão, até uma escravização nas frentes de serviço do açude Araras.

Existem trabalhos fora da curva como este, mas pensamos que ainda há muito que fazer, pois geralmente o que é posto no palco é o período inicial das obras como um alento para os sertanejos, o que realmente foi, mas vale ressaltar que não foi apenas isso, a visita de Juscelino Kubitschek à cidade, a finalização e inauguração do açude, outros aspectos como sua grandeza e importância, também participam do contexto. Bom, e onde está a história dos cassacos explorados dia e noite para que o Araras fosse inaugurado? Por que é tão difícil tocar nas cicatrizes do processo?

Portanto, entendemos que ainda há questões a serem respondidas, e que tais inquietações permeiam um campo vasto de pesquisa. As considerações finais, aqui, não significam o fim, apenas indicam mais caminhos a serem estudados e um amplo percurso a ser desbravado em busca de novas histórias que são deixadas nos bastidores.

\section{Fontes}

QUEIROZ, Rachel de. O Quinze. 19ª ed. Rio de Janeiro, J. Olympio, 1986. Jornal Correio da Manhã (RJ), 11 de maio de 1958/Edição 19975. Jornal Correio da Manha (RJ) 13 de maio de 1958/Edição 19976. Jornal Imprensa Popular (RJ) 17 de novembro de 1953/Edição 01655. Jornal Imprensa Popular (RJ) 17 de novembro de 1953/Edição 01655. Jornal Tribuna do Povo (MA), 7 de Agosto de 1954/Edição 00176.

Disponíveis em: http://memoria.bn.br/hdb/uf.aspx 



\title{
4. Políticas públicas em combate à seca no município de Croatá-CE (1983-1996)
}

\author{
Caubi Alves Braga ${ }^{1}$ \\ Naiane Nobre Martins ${ }^{2}$
}

\section{Introdução}

Ao longo da história, o problema com o estigma da seca sempre foi característica marcante do semiárido brasileiro, região cujos impactos oriundos dos longos períodos de estiagem são frequentes. No decorrer da história, surgiram diversas medidas para o gerenciamento das secas, que tinham o objetivo de "combater" suas origens e/ou consequências, principalmente, aquelas de ordem socioeconômica. Nessa perspectiva, refletindo sobre as iniciativas de "combate" do fenômeno, este estudo objetiva discutir e identificar o período desta transição paradigmática, no âmbito das políticas públicas, analisando, sobretudo, as eventuais mudanças entre as duas perspectivas, no que tange ao "lidar" com o fenômeno das secas, criando e adotando tecnologias para conviver com a situação climática, pois combater um fator natural fica bem mais difícil, pois não se pode combater o que não se pode mudar, sendo assim, criam-se políticas de convivência com o semiárido.

Ao longo da história, o problema com a falta de chuva já estava presente no atual território nordestino, pois desde o século XVI que temos resquícios da presença da seca, pois essa irregularidade de chuva é característica do semiárido nordestino, que é marcado pelo clima típico, onde apresenta irregularidades no tempo e no espaço, por conseguinte é importante ressaltar a influência da chuva em relação ao binômio homem/meio, tanto no aspecto da agropecuária como para o consumo humano, que devido à seca e à falta de políticas públicas causou grandes desastres sociais. Como podemos observar:

A Grande Seca de 1877 a 1879 pode ser considerada como o pior desastre social que já se abateu sobre a sociedade brasileira. Esse desastre propiciou mudanças da maneira como o governo e a sociedade brasileira viam as secas. Foi consequên-

Graduando em Geografia - Bacharelado na Universidade Estadual Vale do Acaraú, e-mail: kaubybraga@hotmail.com.

Graduanda em História - Licenciatura na Universidade Estadual Vale do Acaraú, e-mail: naiane-martins@hotmail.com 
cia desse evento a criação de outra Comissão Imperial para propor soluções para as secas. Essa foi a primeira ação com finalidade de produzir políticas públicas ${ }^{3}$.

De acordo com o contexto histórico, podemos levar em consideração que a primeira seca que se tem como marco de preocupação para os governantes é a seca de 1877 a 1879, que desperta as primeiras intervenções para "combater" a seca, tendo como objetivo a criação de políticas públicas para combater as condições em que se encontrava a população diante da situação imposta pela seca.

Neste sentido, a condição vulnerável que o clima vem propondo desde que conhecemos a história acarreta sérios problemas que precisam ser solucionados pelos poderes competentes, no que compete ao poder público, independente da sua esfera, seja municipal, estadual ou federal; assim, criamse as políticas públicas com finalidade de combater a seca, dando assistência social para a população que se encontra em condições precárias, pois o impacto social e econômico gera instabilidade de forma espantosa.

Esta produção busca apresentar em seu corpo as políticas públicas em combate à seca no município de Croatá- $\mathrm{CE}^{4}$, mostrando as condições de trabalho, forma e resultado das políticas públicas, onde um município que se emancipa em 1989 tem vários marcos dessas políticas. No que tomamos como pretensão, identificamos obras bem estruturadas feitas pelas políticas emergenciais, como calçamentos, cacimbões, barragens, que para aquela época representaram um grande desenvolvimento para a população local, pois levaram condições de trabalho e implantação de infraestrutura, dando assim o real sentido das políticas públicas.

\section{A criação e a aplicação das políticas públicas}

O processo de criação das políticas públicas surge pela necessidade de solucionar um problema social que afeta uma dada parcela da população, visando sempre o bem-estar, neste sentido, é de competência dos três poderes agirem diante de uma dada situação, sendo um trabalho em conjunto. Já no que se refere à execução das políticas públicas, cabe aos poderes executivos de todas as instâncias, dando assim um real sentido de aplicação, fazendo com que a população saia da situação de calamidade. As várias formas de

CAMPOS, José Nilson B.. Secas e políticas públicas no semiárido: ideias, pensadores e períodos. 2014. CAMPOS, José Nilson B. Secas e políticas públicas no semiárido: ideias, pensadores e períodos. Estudos Avançados, São Paulo, v. 82, n. 28, p. 65-88. 2014

4 Croatá é uma cidade do estado do Ceará, está localiza-se na microrregião da Ibiapaba, com uma população estimada 17.994, de acordo com projeção do IBGE de 2018. 
políticas públicas no Nordeste são criadas para garantir o mínimo de condições de sobrevivência da população que atravessava as frequentes secas.

Com todos os registros históricos de escassez de chuvas, esse sofrimento não era visto como um problema para o Estado, pois esse fator era algo característico do semiárido, e que não afetava as bases da economia nacional. Apenas em 1887 houve a compreensão que essas irregularidades de chuvas não eram algo mais associado ao clima, e sim uma questão social que deveria ser revertida, e não mais ignorada pelo governo.

Para reverter as cenas da seca, estando muito associada à fome, miséria e migrações, o governo tomou base de duas medidas, segundo o entendimento dos autores Nys, Engle e Magalhães (2016). Uma das ações emergenciais adotadas era de caráter assistencialista, para reduzir o sofrimento das pessoas afetadas; a outra, de caráter mais permanente, com o objetivo de reduzir vulnerabilidade futura, dando-se assim o surgimento das políticas públicas em combate à seca, com o propósito de solucionar essa questão social.

As políticas que se caracterizam com a redução de vulnerabilidade social futura são integradas nas medidas emergências de acúmulo de água, obras de perfuração de poços, conhecidos popularmente como cacimbões, estas muito desenvolvidas no município de Croatá-CE, pois desde quando a seca se tornou um problema social, havia a necessidade de uma demanda de projetos para atender à população que sofria com a estiagem de água e de recursos para resistir ao sol escaldante do sertão nordestino.

Os projetos de combate à seca, presente no município de Croatá, eram comuns como nas demais regiões, como a construção de poços, barragens e calçamentos; fazia parte de um cenário onde a população via na construção uma forma de sobreviver a essa terra castigada pela seca. A busca pela água, assim como pela retenção através de barragens e das escavações na construção dos poços, garantia a passagem de uma seca para outra, além de garantir abastecimento de água à população gerava empregos e renda que seria capaz de garantir bens alimentícios, ou seja:

Garantir água para as populações dispersas tem sido uma resposta comum em todas as secas. Isso tem sido e continua sendo feito, durante muitos anos, com a utilização de carros-pipas, que levam água de fontes existentes, geralmente açudes ou poços, até as comunidades isoladas 5 .

Essa medida de retenção de água através de barragens e poços ficou conhecida como solução hídrica, pois essa seria a forma de acumular a água

DENYS, E.; ENGLE, N.L.;MAGALHÃES, A.R. Secas no Brasil: política e gestão proativas. Brasília, DF: Centro de Gestão e Estudos Estratégicos- CGEE; Banco Mundial, 2016, p. 292. 
das chuvas para ser utilizada nos períodos de seca. Como também garantir para a família uma forma direta e um emprego remunerado que vinha dar garantia para o sustento familiar, ou seja, no momento em que o representante da casa passava a trabalhar, ganhava uma quantia e uma cesta básica para complementar a renda.

\section{Os resultados das políticas em combate a seca em Croatá-CE}

Com o propósito de remediar a situação emergencial, as politicas públicas em combate à seca tiveram grande relevância dentro de um recorte espacial do município de Croatá-CE, onde em parceria com o sindicato dos trabalhadores, tanto do município vizinho de Guaraciaba do Norte como o sindicato de Croatá, tiveram seu papel primordial na aplicação desse projeto social.

Com a primeira edição das políticas públicas em combate à seca em Croatá-CE é notória a contribuição de forma satisfatória a partir de entrevistas realizadas no município, pois a partir de dados amostrais podemos observar que essas políticas atingiram realmente seus propósitos, pois segundo o entrevistado Raimundo Nonato Braga Marques ${ }^{6}$, onde o mesmo faz abordagem sobre as edições dos projetos sociais em combate à seca, afirma

48| que a primeira edição em Croatá se deu no ano de 1983, nesse período as condições ainda eram precárias, pois as formas que as políticas eram aplicadas não eram totalmente como deviam ser.

Já nas outras edições -foram apenas quatro edições no município de Croatá-CE - foi que a situação veio de forma mais objetiva, mas com o passar do tempo teve um melhoramento em todas as condições, pois o projeto mais presente no município foi o conhecido "Bolsão", que tinha a finalidade de construir obras emergências em determinadas localidades, propondo emprego e gerando renda para a população, pois a partir do momento em que se tinha trabalho remunerado já não precisava mais migrar para outro município ou estado, fazendo com que mantivesse a permanência em seu local de origem.

O processo de aplicações das políticas públicas emergenciais propôs certos desenvolvimentos em determinadas localidades, pois a maioria das comunidades enfrentavam situações precárias por causa da seca e a partir das obras dos bolsões a situação começou a melhorar, haja vista que a implantação de infraestruturas trouxe melhorias sociais e econômicas.

Com essas oportunidades chegando para contribuir com o desenvolvimento local, era feito o recrutamento dos trabalhadores, pois segundo o

Raimundo Nonato Braga Marques, 60 anos, agricultor. Entrevista realizada por Naiane Nobre Martins, 16 de setembro de 2018. Burtiti - Croatá, CE. 
entrevistado Francisco Nobre Martins ${ }^{7}$ era de encargo do sindicato dos trabalhadores realizar esse recrutamento. A participação no programa bolsão se dava da seguinte forma: era feito um cadastro com um representante do sindicato dos trabalhadores, onde o sindicato tinha convênio com a CODAGRO (Companhia Cearense de Desenvolvimento Agropecuário) que ficava responsável pelo contrato dos trabalhadores.

Havia todo um processo burocrático de contratação dos trabalhadores. Só um representante de cada família poderia trabalhar. As formas de trabalhos eram diversas, como nas construções de barragens, calçamentos e poços profundos escavados manualmente (conhecidos como cacimbões). Essas construções foram as mais presentes no município de Croatá.

As construções que foram feitas na época dos bolsões resistem até os dias atuais, pois é comum encontrarmos calçamentos e cacimbões no município, porque foram obras para o desenvolvimento social que realmente deixaram suas marcas dentro de um contexto pobre que, com o passar do tempo, foi superado pelas diversas formas de desenvolvimento das políticas públicas para a sociedade.

Nas seguintes imagens podemos observar grandes obras e sua relevância dentro de um contexto local pertinente àquela época, pois sua construção evitou várias situações de calamidade social, além de ter gerado emprego e renda para a população local.

Imagem 01: Calçamento na localidade de Buriti dos Bragas, Croatá - CE.

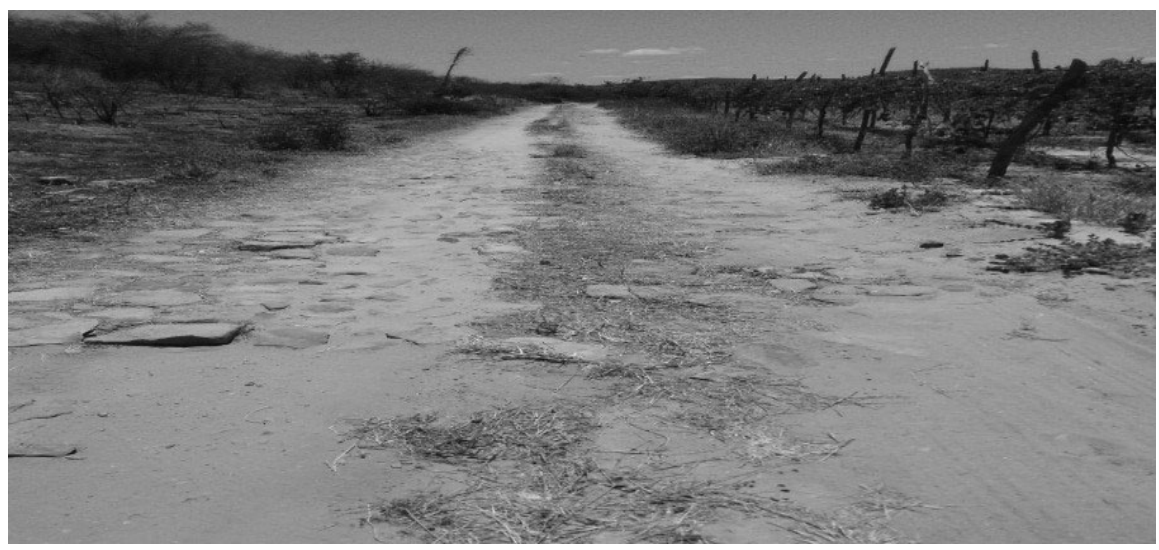

Fonte Braga: (2018)

Segundo Raimundo Nonato Braga Marques ${ }^{8}$, esse calçamento foi feito na primeira edição do bolsão em Croatá-CE, no ano de 1983, onde foi adotada

Francisco Nobre Martins, 56 anos, agricultor. Entrevista realizada por Naiane Nobre Martins, 16 de setembro de 2018. Entrevista realizada em sua residência, Betânia - Croatá, CE.

8 Ibidem. 


\section{Nossa Gente,}

\section{Nossa História}

o Ceará Republicano

a política de abertura de estradas, como também a manutenção de alguns trechos onde tinha muita areia que impedia a passagem de alguns veículos. Imagem 02: Cacimba

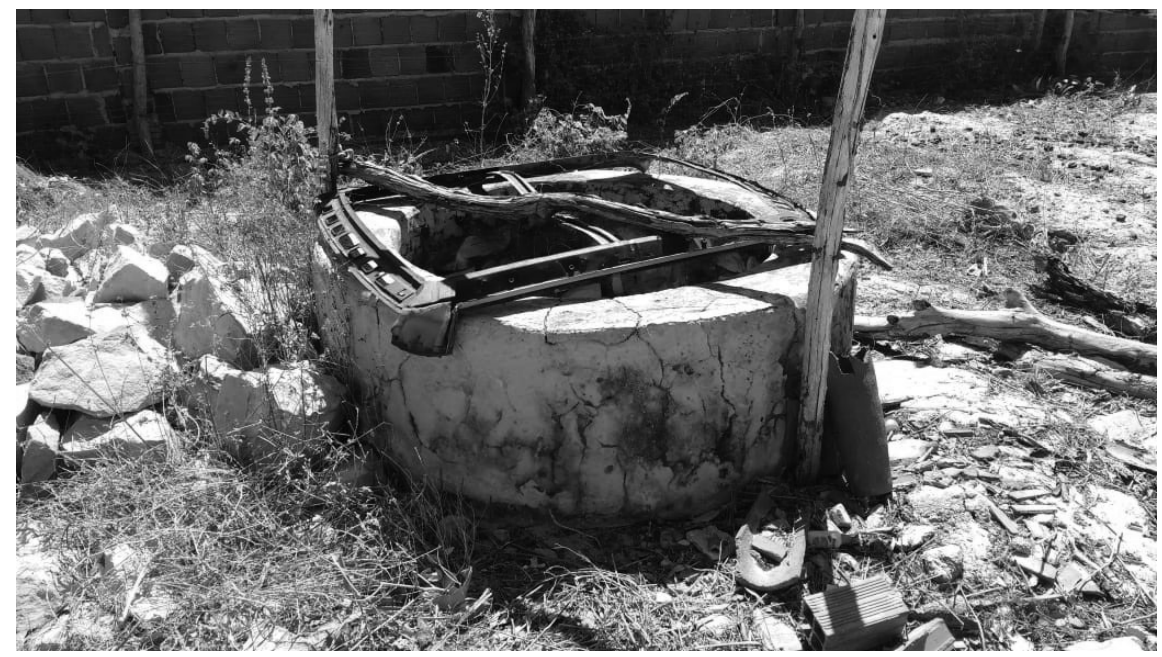

Fonte: Braga (2018)

Imagem 03: Estrutura do cacimbão.

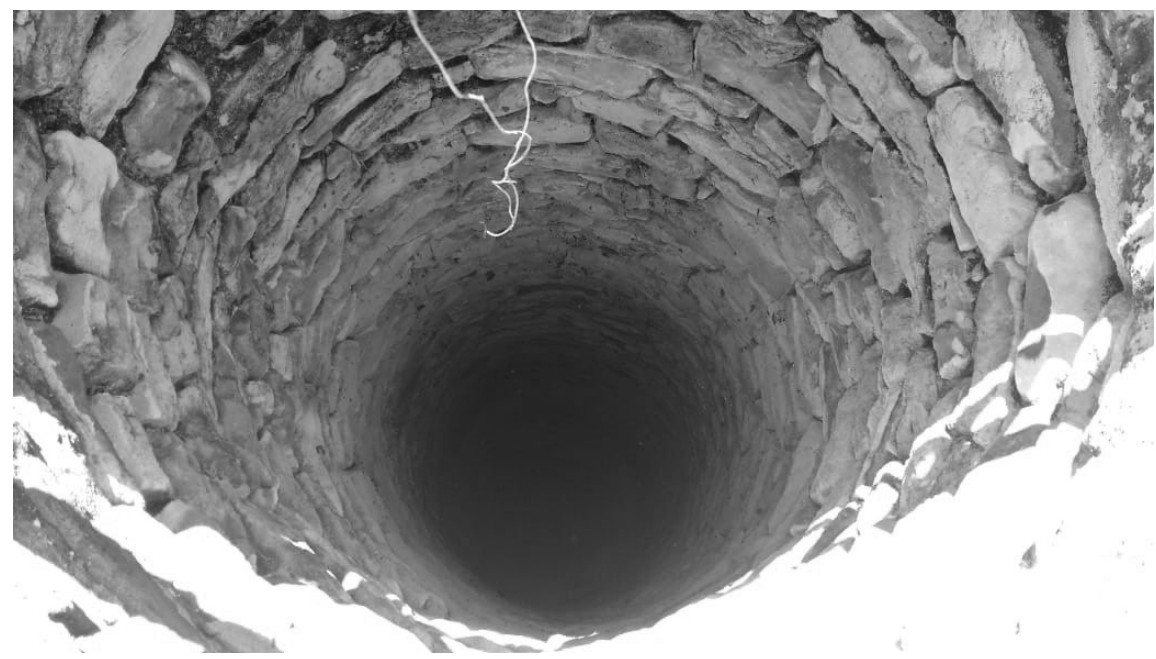

Fonte: Braga (2018).

Com a perfuração dos poços profundos, conhecidos popularmente como cacimbões, houve a possibilidade assistência no consumo de água para as localidades beneficiadas, onde o grupo de funcionários do programa bolsão perfurava o solo até chegar à água, encontrando-a em forma líquida a felicidade para o povo que necessitava saciar a sede. 
Imagem 04: Barragem na localidade de Vazante, Croatá - CE.

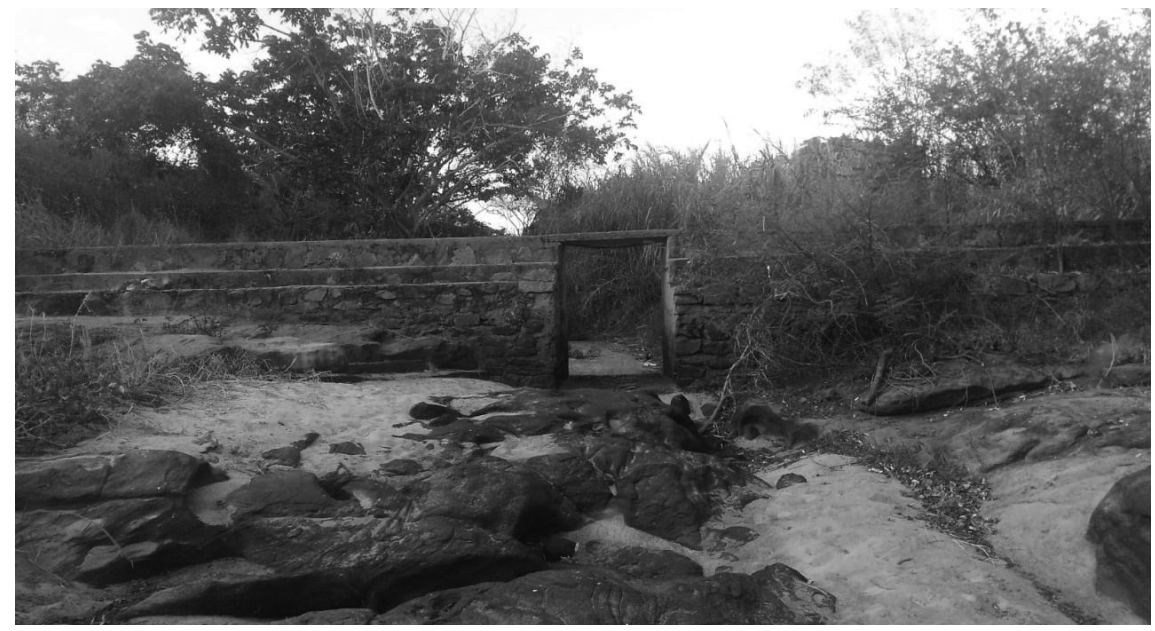

Fonte: Braga (2018).

As barragens eram uma das tecnologias para combater a seca, onde naquela época a retenção e acúmulo de água eram vistos como uma solução hídrica, favorecendo assim o desenvolvimento da agricultura familiar, o consumo humano e dos animais. As barragens eram construídas pelos trabalhadores das comunidades beneficiadas, onde recebiam um pagamento pelo serviço prestado juntamente como os benefícios das barragens.

\section{Política de combate à seca ou de convivência?}

Ao longo do período da falta de chuva no semiárido nordestino, isso que já era característico desde muito tempo, algo que é natural do clima, não seria visto como problema natural, mas sim um problema que deveria ser combatido, por isso a utilização dos termos: políticas públicas em "combate" à seca; se a massa populacional soubesse conviver com as particularidades desse clima, ou seja, viver em harmonia com a natureza, não causaria tantas mazelas, e não iria protagonizar a imagem de uma região onde a dor era vista no semblante da população.

Sabemos das inúmeras políticas públicas de controle ou combate à seca, mas nos deparamos com suas falhas ao serem aplicadas, pois a oferta desses projetos não seria capaz de reverter a situação em que a população encontrava-se, haja vista que esses projetos emergenciais não teriam como suportar todas as necessidades que a população enfrentava dia após dia e, como pode ser visto, percebemos a fragilidade na aplicação desses projetos. "O despreparo das autoridades manifesta-se principalmente na ausência de medidas 
preventivas e no caos administrativo provocado pela presença dos retirantes famintos novamente em Fortaleza"9 (NEVES, 2000, p. 84).

Essas políticas de "combate" à seca, ou seja, para solucionar o problema da falta de água, era visto como algo fundamental e importante, mas havia outra questão por trás desse contexto, que seria "combater" a migração dos flagelados para a capital, que estava se estruturando em uma sociedade moderna e civilizada, espelhando-se nos modelos europeus, ou seja, manter a população no seu lugar de origem seria um fator primordial para não acarretar mais tantos problemas para os centros urbanos, portanto:

[...] O trabalho em grandes obras públicas foi-se tornando o principal mecanismo para manter a população sertaneja em locais próximos aos seus locais de origem, impedindo uma mobilidade mais intensa dessa população faminta ${ }^{10}$.

Com todos esses planos emergenciais de "combate" à seca e da "fixação do homem no campo", percebemos a mudança de posicionamento em relação à seca, antes não era vista como um problema social, e sim uma questão relacionada ao clima, mas que tomou proporções e entendimento que deveria ser combatido, ao invés de aprender a conviver com esses fatores climáticos característicos da região. Desta forma, a seca incorpora-se a um conjunto de medidas governamentais voltadas ao combate, ao invés de relaciona-se com esse fenômeno natural.

A seca não deveria ser vista como um problema que poderia ser combatido, mas sim serem criadas tecnologias de convivência, pois a população e os governantes é que deveriam se adaptar às suas circunstâncias para sobreviver em seu tempo, que não deveria ser motivo de desespero se tivéssemos políticas que intercedessem beneficiando a todos, desta forma, o poeta Brás Costa traz uma reflexão em seus versos sobre seca, que é um fenômeno natural e injustiçado.

\section{Poesia Irmã Seca, do Poeta Brás Costa}

Mas na verdade irmã seca,

Tu não tens culpa de nada.

És bode expiatório,

De uma política safada.

Que diz que só faz o bem,

Roubando de quem não tem,

\footnotetext{
NEVES, Frederico de Castro. A seca na História do Ceará. In: SOUSA, Simone de (Org.) Uma nova história do Ceará. Fortaleza: Fundação Demócrito Rocha, 2000, p. 84.

10 Id. Ibid., p. 88.
} 
Depois usando teu nome.

Cria leis só para alguns,

Leis que enriquecem uns,

E matam muitos de fome.

Não irmã, tu não tens culpa

És um fator natural,

No meu nordeste tem seca

Mas é seca de moral.

Temos uma seca crítica

Mas é seca de política

Que almeje o bem comum.

E não nos dê duras penas

Mate de fome centenas

Para saciar só um.

(COSTA, 2012, p. 01).

Neste sentido, a solução mais compreensível para "combater" a seca seria criar tecnologias de convivência com a situação climática, pois sendo um fator natural não se tem condições para combatê-la. O ideal seria aplicar políticas públicas com propósito de solucionar os problemas sociais causados pela seca, fazendo com que a população venha conviver com a situação climática, pois adotando as tecnologias de conivência com o semiárido seria a melhor forma de remediar o problema da seca.

\section{Considerações finais}

Diante do exposto, podemos entender que as políticas públicas têm o papel primordial de solucionar ou intervir em alguma problemática de fragilidade social, no que concerne à problemática da seca, compreendemos que a situação não pode ser combatida como era proposto pelas primeiras políticas públicas, pois por ser um fator natural do clima característico do semiárido brasileiro não se pode ser combatido.

Criam-se políticas públicas para "combater" a seca, mas como não se pode combater, o ideal é adotar tecnologias para conviver com a estiagem, pois seria a melhor forma de solucionar o problema, dando assim o real sentido a adoção das tecnologias de convivência com o semiárido, pois armazenar água e utilizar de forma benéfica seria uma das melhores opções de conviver com a estiagem.

Com as políticas públicas sendo utilizadas para conviver com o clima semiárido a situação melhorou bastante no contexto das secas, pois o senário 
Nossa Gente,

Nossa História

o Ceará Republicano

mudou de forma clara e objetiva, pois hoje temos vários incentivos para investimento no semiárido nordestino, já no recorte espacial do município de Croatá-CE podemos identificar várias iniciativas pelo PRONAF (Programa Nacional de Fortalecimento da Agricultura Familiar), que financia poços artesianos para os produtores rurais, fazendo com que melhore sua produção a partir da água do subsolo.

Temos também as cisternas de placas para o armazenamento de água das chuvas, o programa das sementes para todos, e o bolsa família que complementa a renda dos agricultores.

É nesse sentido que as políticas públicas têm realmente suas finalidades e resultados, pois através da adoção de tecnologias para a convivência com o semiárido é que podemos oferecer condições da população conviver com as condições climáticas em seu local de origem. 


\title{
5. A seca e as obras de socorro no Ceará republicano (1889- 1915)
}

\author{
Pedro de Souza Filomeno Filho ${ }^{1}$
}

\section{Introdução}

Pensar sobre a migração populacional no final do século XIX e início do século XX é refletir sobre o processo de constituição da população numa sociedade, pois neste momento as configurações sociais e culturais se alteram, ordenando grupos urbanos com a intenção de organizar e disciplinar o trabalhador nessa nova nação, agora republicana. Ao estudar as migrações causadas pela seca e também por circunstâncias políticas, devemos perceber o cenário desses migrantes, este ambiente repleto de questões políticas e de interesses relacionados ao poder.

Deste modo, é preciso entender que essa migração interna que houve no Brasil não deve ser analisada apenas como deslocamento populacional, é o que debate Viviane Lima de Morais:

Devemos nos pautar na análise da dialética da expulsão e constituição de uma população participe de um processo de reconfiguração dessa sociedade. Isto no momento em que surgem importantes modificações técnicas, sociais e culturais, ordenando núcleos urbanos com fazeres e viveres próprios, articulados à intenção de organizar e disciplinar um pretendido trabalhador nacional ${ }^{2}$.

Relacionando política e seca, entende-se que até a estiagem de 1877, as secas frequentavam a zona de calamidade pública, porém, a partir desse momento, as secas adquiriram novas funções. Pois, o partido liberal do Ceará liderado pelo Senador Pompeu, começou a utilizar as secas para a construção de empreendimentos públicos em troca de ações assistencialistas, observemos a proposição de José Weyne de Freitas Sousa:

Em 1878, segundo ano da dita grande seca, o aliado político de Pompeu, o senador Sinimbú, dirigiu uma mensagem a D. Pedro II com um decreto em anexo, no qual tornava oficial o aproveitamento da mão de obra disponível para a realização de

Graduando do Curso de Licenciatura em História da Universidade Estadual Vale do Acaraú - UVA. MORAIS, Viviane Lima de. Representação do migrante: o cearense e a questão do nomadismo no século XIX. Projeto História, São Paulo, 27, p. 269-282, dez. 2013, p. 269. 
obras públicas. Para a consecução desse projeto houve a aprovação de recursos utilizados para socorrer os desvalidos com alimentos e trabalho. O importante nisso tudo foi que se incluiu uma nova modalidade de socorro: o socorro público indireto. Já havia o socorro direto, mas a partir de 1877 o socorro indireto se tornou uma contrapartida para o socorro direto ${ }^{3}$.

Neste caso, observamos os migrantes oriundos das secas no Ceará oitocentista e sua transição ao período republicano, analisando as estratégias de medidas de controle e direcionamento de suas ocupações.

\section{A proposta do Senador Sinimbú}

Em 1878, o senador Sinimbú propõe utilizar as secas como forma de alocar os flagelados em obras públicas e ofertar socorro a partir do trabalho gerado na seca de 1877, uma seca de grandes proporções. Esta proposta incentivou a migração de um grande contingente populacional oriundo do sertão, indo em direção aos socorros públicos planejados no litoral. Isto explica a intensa movimentação para o litoral nesta seca, diferente de outras, resultando além do abandono de domicilio de milhares de pessoas, chegando ao objetivo planejado de um projeto político encabeçado pelas elites cearenses, intimamente ligadas ao Partido Liberal, visando à equiparação, no que se refere ao progresso material, das províncias do Norte em relação às províncias do Sul (SOUSA, 2009).

Durante a seca de 1877-1879, houve a implantação do projeto de desenvolvimento econômico para o Norte, elaborado pelo Senador Pompeu, pautando-se no objetivo de equiparar o Norte ao Sul, para diminuir as diferenças entre as duas regiões, diferenças estas, sobretudo ideológicas:

Assim, antes de 1877 a principal diferença entre o Norte e o Sul, não era econômica, mas política, pois com a queda o que havia era diferenciação política. Com a queda do Ministério Zacarias resultante do desentendimento entre o político baiano Zacarias de Góes e Vasconcelos e o Imperador D. Pedro II, teve início em 1868 o gabinete conservador do Visconde de Itaboraí. Essa mudança repercutiu nos cenários políticos locais favorecendo os conservadores e eclipsando os liberais. Capistrano de Abreu anotou que Zacarias até o fim da vida não perdeu ocasião para "lacerar ou morder D. Pedro II". O Imperador por sua vez, acrescentou em tom de ironia, somente chamou os liberais ao poder apenas depois de 'Zacarias bem enterrado no cemitério do Catumbi'. (ABREU, 1998: 432-445). De fato, 
durante esse período os políticos liberais amargaram o ostracismo de dez anos, até que em 1878 assumiu um ministério liberal presidido por João Lins Vieira Cansanção de Sinimbút.

Dessa maneira, alocar os flagelados nessas construções era algo que se somava a esta proposta de desenvolvimento da região. No entendimento de Sousa: "No Ceará o esforço político de transformar a seca de 1877 numa 'grande seca' foi o marco divisório entre as duas regiões do país, no que concerne ao território e a organização política. Com isso, os interesses locais e imediatos se sobrepuseram aos interesses nacionais"5.

O que propiciou também intensas e violentas disputas eleitorais entre as duas regiões. Situações que muitas vezes eram resolvidas em emboscadas e na pistolagem, recursos comuns entre os dois lados.

\section{As ideias de André Pinto Rebouças para o combate da seca e desenvolvimento regional}

André Pinto Rebouças foi um engenheiro conhecido pelo seu viés liberal, tendo atuado no movimento abolicionista na década de 1880. Ele também foi responsável por pensar ações voltadas para os trabalhadores no período de secas da região.

Durante sessão extraordinária, realizada no Instituto Politécnico do Rio de Janeiro em 18 de outubro de 1877, em que foram discutidas medidas para solucionar o problema da seca, entre engenheiros da então Corte brasileira, homens de classe política, integrantes da nobreza local, e curiosos interessados no debate, colocou-se em pauta a implantação do "plano Gabaglia", que significava:

[...] a construção de açudes, estradas, portos e de ações de reflorestamento do já então falecido Giacomo Raja Gabaglia, topógrafo da Comissão Científica de Exploração enviada ao Ceará em 1859, cujas propostas eram então as mais acreditadas como meios capazes de dar solução aos problemas das secas ${ }^{7}$.

\section{Id. Ibid., p. 3.}

Idem, p. 3.

Giacomo Raja Gabaglia foi topógrafo da Comissão Científica de Exploração enviada ao Ceará em 1859-1861, cujas propostas eram então as mais acreditadas como meios capazes de dar solução aos problemas das secas. Produziu artigos como ensaios sobre alguns melhoramentos tendentes à prosperidade da Província do Ceará.

CÂNDIDO, Tyrone Apollo Pontes. Proletários das secas: arranjos e desarranjos nas fronteiras do trabalho (1877-1919). Tese (História Social) - Departamento de História, Programa de Pós-Graduação em História Social Universidade Federal do Ceará, Fortaleza, 2014, p. 138. 
Nossa Gente,

Nossa História

o Ceará Republicano

Enquanto a maioria dos engenheiros na ocasião acreditava em medidas de combate à seca como:

\begin{abstract}
[...] meio para se socorrer aos vitimados pelas secas seria o investimento em melhoramentos materiais que propiciassem a continuidade da produção sertaneja (através da criação de reservatórios de água em regiões apropriadas) e (por meio da construção de ferrovias e estradas distritais) garantissem o escoamento dessa produção, além de se permitir com que os socorros (seguindo num sentido contrário) do litoral alcançassem o interior seco ${ }^{8}$.
\end{abstract}

André Rebouças apresentou proposições diferentes, afirmando que era necessário dar abrigo, alimentação, cuidados médicos, trabalho e salários para que os retirantes pudessem sobreviver a tal calamidade. Criando também postos de abastecimento que trariam para as regiões uma maior dinâmica econômica. Ele tinha uma estratégia para resolver o problema das secas: "Empregar as vítimas da seca em atividades industriais propiciadas pelos centros de abastecimento montados pelo governo para que, em seguida, fosse possível a reconquista do sertão, através de açudes, estradas e canais"g.

Desde as proposições de André Rebouças, foram feitas muitas referências aos empreendimentos funcionarem como socorros públicos, trazendo 58 a ideia de ocupar as grandes massas de retirantes, dando-os empregos em atividades úteis para o Estado ${ }^{10}$.

[...] pronta execução de vias férreas já estudadas na região flagelada pelas secas para dar trabalho e salário aos retirantes, desapropriação dos terrenos marginais dessas vias férreas para serem divididos em lotes e neles fixar os retirantes, executar obras de melhoramentos de portos marítimos e fluviais, notoriamente os de Fortaleza, Aracati, Natal e Cabedelo, aproveitando a mão de obra dos retirantes ${ }^{11}$.

Percebe-se que André vislumbrava além de melhoramentos de cunho material, a formação de uma classe de trabalhadores que guiados por grandes empreendedores poderiam se tornar agentes em potencial para o desenvolvimento do país. Para ele, o trabalho gerado nas obras públicas e destinado aos migrantes funcionaria como uma caridade a estes grupos e um investimento para o governo.

Para Cândido, o engenheiro André Rebouças defendia que haveria grandes benefícios a partir dos investimentos governamentais promovidos ao so-

CÂNDIDO, Tyrone Apollo Pontes, Op. cit., p. 139.

Ibid., p. 140.

10 Ata da Sessão Extraordinária do Instituto Politécnico, em 18 de outubro de 1877. Revista do Instituto Polytecnico Brazileiro, tomo XI, 1878. BN.

11 REBOUÇAS, André, 1878, p. 28, apud CÂNDIDO, Op. cit., p. 141. 
corro dos retirantes da seca. Obras como a construção de ferrovias, açudes, portos, e a futura alocação de retirantes em fábricas de beneficiamento e oficinas levariam a uma recuperação do sertão, influenciariam em uma alteração significativa das condições sociais. Ele acreditava que esse seria um passo para um processo mais amplo, imaginando em sua concepção a construção de uma "democracia rural"12.

Em síntese, pelas ideias de André Rebouças, "iniciaram-se as estratégias de organização das grandes obras de socorros públicos enquanto meios de se empregar em trabalhos úteis as imensas massas de retirantes"13.

\section{A mudança de regime e a manutenção da política de socorros}

Durante a seca de $1888-89$, três obras foram as mais difundidas, sejam pela imprensa ou em ofícios, relatórios e discursos parlamentares, como grandes centros de contenção de sertanejos: os prolongamentos das ferrovias de Baturité e de Sobral e a construção do açude de Quixadá. Diferente do momento anterior de seca, as estações não estavam mais se constituindo no litoral, agora já se encaminhavam para o centro do estado, o que evitaria que os miseráveis chegassem à capital, pois seriam destinados a esses serviços de prolongamento.

Tendo em vista que a Estrada de Ferro de Baturité já havia sido concluída de Canoa a Baturité nos anos 1882, então deveria no momento seguir até o ponto de Quixadá. Já a Estrada de Ferro de Sobral na época tinha como traçado inicial a ligação do Porto de Camocim a Sobral, e posteriormente deveria ir de Sobral até Ipú, na beira da Serra da Ibiapaba. Para o governo era extremamente importante a realização das obras de Baturité, pois possibilitaria grande produção algodoeira, e os lucros seriam superiores aos gastos, sem falar que aproximariam grandes centros de consumo, como Icó e Crato, do porto de Fortaleza. Benefícios também eram apontados na construção do açude de Quixadá, que influenciaria nas obras de irrigação mais modernas que beneficiariam os vales da região, visando o progresso com a construção do açude.

Pensando em solucionar problemas da estiagem de 1888-89, sendo eles: migrações, falta de alimentos, morte de animais, pessoas e a queda do comércio, foram colocados em prática estudos e propostas elaboradas por engenheiros na seca anterior, que naquele momento não haviam sido executadas plenamente, mas neste novo cenário já se via com mais clareza o objetivo dessas obras:

12 REBOUÇAS, André. A secca nas provincias do norte. Rio de Janeiro: Typ. de G. Leuzinger\& Filhos, 1877 , p. 53

13 CÂNDIDO, Tyrone Apollo Pontes, Op. cit., p. 146. 
Se durante a seca de 1877-79 a importância das grandes obras de socorros públicos já havia sido ressaltada no sentido de serem instrumentos para o progresso econômico, agora esse caráter estratégico das obras públicas ganhava contornos mais bem definidos: a EFB, a EFS e o açude de Quixadá em conjunto funcionariam como poderosos artefatos para afastar definitivamente a miséria do horizonte de expectativas do Ceará ${ }^{14}$.

A estratégia de socorro aos retirantes durante a seca de 1888-89 pode ser entendida a partir de sua principal característica, a larga escala de obras públicas como caminho para conter e alimentar os migrantes no Ceará. Já nos meses finais desta seca, uma nova dinâmica migratória entrava em cena, os próprios migrantes circulavam em busca de novos locais de trabalhos, procuravam novas obras para se ocuparem e receberem o socorro.

A mudança de regime em 1889 não modificou em linhas gerais a política de controle sobre os retirantes por meio do emprego em obras públicas. Comprovação disto é que o governo republicano deu continuidade às obras de socorro que vinham ocorrendo desde as últimas secas:

Um aviso oficial de 19 de novembro de 1890 expunha, nesse sentido, a resolução do governo federal em prolongar a Estrada de Ferro de Baturité até a cidade do Crato, autorizando o início imediato dos estudos preparatórios para o avanço da linha. A retomada da construção do açude de Quixadá, após paralisação por alguns meses decorrente do afastamento do engenheiro Jules Revy, seria autorizada através de uma portaria de 18 de março de 1890, aprovando novas instruções para as obras, agora sob a direção do engenheiro Ulrico Mursa ${ }^{15}$.

No decorrer do período republicano, o governo federal passou a executar parte das ações propostas pela Comissão Imperial, como a criação de instituições federais que buscassem soluções, em vez das comissões imperiais, o que significou um forte progresso na busca de soluções para o problema. Um dos grandes marcos do período republicano foi o estabelecimento da Inspetoria de Obras Contra as Secas (IOCS) em 190916.

Desde o início do período houve uma preocupação mais efetiva sobre a funcionalidade destas obras, pensando em reduzir os prejuízos causados por muitas interrupções que ocorriam durante as construções, como o adiamento dos benefícios que a obra traria, desperdícios de materiais e a dispensa de

\footnotetext{
Id. Ibid., p. 166.

CÂNDIDO, Tyrone Apollo Pontes, Op. cit., p. 172.

16 CAMPOS, José Nilson B. Secas e políticas públicas no semiárido: ideias, pensadores e períodos. Estudos Avançados, São Paulo, v. 82, n. 28, p. 65-88. 2014.
} 
trabalhadores já estabilizados em uma área. Tal queixa é registrada em ofício ${ }^{17}$ pelo engenheiro Ernesto Antonio Lassance Cunha, diretor da Estrada de Ferro de Baturité, em 25/08/1891.

Em 1891, a estação das chuvas decepcionou, aparecendo tardiamente e fraca, o que prejudicou o prolongamento da estrada de Baturité, mas também serviu como um alerta para o governo, que buscou a partir daí se antecipar a este tipo de acontecimento se prevenindo de gastos em obras incompletas e pensando em recursos para lidar com os retirantes vindos nas futuras estiagens.

Os primeiros anos da década de 1890 apresentaram significativos avanços nos serviços de socorro nas obras públicas no Ceará:

No açude de Quixadá - onde durante a seca de 1889 havia sido concluída uma estrada de acesso desde Canoa, erguidos edifícios para oficinas, depósitos e abrigos para operários, perfuradas diversas cacimbas e preparado o grande alicerce (de 16 metros de largura) da parede central - teria nos anos seguintes levantado suas quatro barragens e dois sangradouros, para os quais turmas de trabalhadores de duas pedreiras enviavam rochas através de troles que circulavam constantemente por linhas férreas paralelas estendidas até a parede central. A via férrea de Baturité também avançaria em sua extensão naqueles anos, inaugurando diversas estações nos 47 quilômetros entre Quixadá e Quixeramobim e, logo em seguida, nos 57 quilômetros desde aquele ponto até Humaitá1 ${ }^{18}$.

\section{A seca nos anos 1900}

O ano de 1900 parecia surpreender por um elevado número de chuvas logo no início e pela reserva de água ainda acumulada nos açudes, mas até aí não se sabia que este seria o ano do século XIX de estiagem mais intensa no que diz respeito a ausência de chuvas.

Nesse sentido, passa-se a questionar o governo federal na pessoa de Campos Sales, aparentemente mais preocupado em investir verbas do tesouro nacional na cafeicultura paulista do que nas obras de socorro no Ceará. Cândido aponta que alguns anos depois de toda a euforia causada pela Repúbli$\mathrm{ca}$, voltava à cena certo saudosismo pelo tempo do Império, período em que supostamente não havia restrição de verbas para o amparo de miseráveis. Ocorreu certa pressão sobre o governo ter esquecido as ajudas que deveriam ser destinadas ao Ceará.

17 Arquivo Nacional. Ofício de 31/08/1891, Dec. 643, caixa 11 M7, Decretos do Executivo - República.

18 CÂNDIDO, Tyrone Apollo Pontes, Op. cit., p. 174. 
Contudo, apenas em novembro daquele ano são iniciadas as obras de socorro com verbas oficiais. Sendo "elas as obras de construção dos açudes de Quixadá, do Riacho do Panta (Baturité), Acaraú-Mirim, Papara (Maranguape), Jordão (Sobral) e Acarape do Meio"'19. Ainda assim, insuficientes para empregar toda a demanda gerada de migrantes.

Com a chegada do ano de 1901 e suas chuvas, o governo federal suspende os recursos para as obras de socorro, parando ou reduzindo os trabalhos nos açudes Riacho do Panta e Papara, e no reservatório de Quixadá.

Entende-se que, a partir disso, as obras de socorro nos anos 1900 exercem um papel de menos força do que em anos anteriores, no que tange ao controle dos retirantes. Os pobres que não migraram para outros estados foram auxiliados por instituições beneficentes, como o Centro Cearense, em Fortaleza, sendo auxiliado em sua manutenção pelas Senhoras da Caridade ${ }^{20}$ . No entanto, esse período é imprescindível para se entender melhor os mecanismos de controle dos retirantes.

Nesse contexto, naquele momento existia a necessidade de sistematizar serviços relacionados aos socorros, como ter um plano de serviços. Nas primeiras décadas do novo século, pensou-se diretamente sobre aprender com as experiências do passado, para evitar erros muitas vezes cometidos em situações de emergência. Várias propostas foram postas em análise para se 62 pensar na melhor aplicação dos recursos nas obras, para que trouxessem soluções reais para os problemas da estiagem.

Apesar de que nesse recorte não tenham ocorrido secas como a de 1877 e 1915, o período entre os séculos foi recheado de anos de estiagens graves, registradas nos anos de 1898, 1900, 1902, 1903 e 1907. Anos marcados por chuvas escassas e fome, sinais que pareciam avisar sobre uma estiagem mais forte nos anos seguintes, o que provocou a cobrança de providências ao governo, pautando um serviço de socorro permanente:

Foi nesse contexto que o governo federal ordenou que a Comissão do Açude de Quixadá se constituísse em Comissão de Açudes e Irrigação, dedicada ao estudo e planejamento de obras de construção de represas pelos territórios secos do Ceará e estados adjacentes. O principal objetivo dessa comissão seria o estudo para a reparação dos açudes já construídos, além do planejamento de novos reservatórios ${ }^{21}$.

A partir disso, começou-se a pensar que uma solução para os problemas das secas só poderia estar associada ao acesso que as populações do interior

Id. Ibid., p.176.

20 TEÓFILO, Rodolfo. Seccas do Ceará (segunda metade do século XIX). Rio de Janeiro: Imprensa Ingleza, 1922.

21 CÂNDIDO, Tyrone Apollo Pontes, Op. cit., p. 179. 
tivessem à água. "Era a consagração do que ficaria conhecida como a 'solução hidráulica' aos problemas das secas" ${ }^{22}$. Durante a existência da Comissão de Açudes e Irrigação e, em sequência, durante os primeiros anos da Inspetoria de Obras Contra as Secas (IOCS), as ações desses órgãos empenharam-se nos serviços de perfuração de poços e construção de represas.

Tendo sido a Inspetoria de Obras Contra as Secas (IOCS) um instrumento importante para a obtenção de recursos da parte das classes dominantes nortistas, estabeleceu-se o que ficaria conhecido como a "indústria da seca", revelando na prática essa prevalência de critérios técnico-científicos para o prosseguimento das obras de socorros públicos, não estava tão dissociada dos jogos de poder e disputas sociais em curso (CÂNDIDO, 2014).

O primeiro grande pensador na formulação e aplicação da construção da infraestrutura hidráulica foi o engenheiro Miguel Arrojado Lisboa, superintendente da Inspetoria de Obras Contra as Secas (IOCS). Em discurso no Clube de Engenharia do Rio de Janeiro, em 28 de agosto de 1913, expressou seu entendimento da complexidade do problema das secas, ao afirmar:

Seca, no rigor léxico, significa estiagem, falta de umidade. Da chuva provém a água necessária à vida na terra. $\mathrm{O}$ problema das secas, assim encarado, seria simplesmente o problema da água, isto é, do seu suprimento. Mas a palavra seca, referida a uma porção de território habitado pelo homem, tem significação muito mais complexa. Com efeito, o fenômeno físico da escassez de chuva influi no homem pela alteração profunda que dela decorre para as condições econômicas da região, que por sua vez se refletem na ordem social. Assim encarada a seca é um fenômeno muito vasto tanto de natureza física quanto econômica e social. O problema das secas é, portanto, um problema múltiplo. Verdadeiramente não há um problema, há problemas $^{23}$.

Grande parte desse período ,que se estende desde a constituição da Comissão de Açudes e Irrigação em 1903 até o início da grande seca de 1915, passando pelo momento da criação da IOCS em 1909, pode ser entendido como um momento de grandes acúmulos de saberes sobre o fenômeno das secas e elaborações de diversos projetos para a construção de obras de socorros públicos, que viriam para minimizar os efeitos das secas.

\section{Considerações finais}

Em um cenário de seca, fome e desespero a população carente do Ceará se encontrava no final do século XIX e início do XX. Retirantes em busca 
de sustento, vivendo em um período em que a concepção da força poderia ser medida através dos que resistiam ou não à seca, em que os mais fortes sobrevivem, temos em observação uma síntese do darwinismo aplicado à calamidade causada pelas estiagens e pelas políticas públicas Ceará.

Com as migrações observamos um fenômeno de aumento da população, que faz com que a miséria cresça ainda mais, através do aumento de preço de produtos, segundo as ideias de Sousa. E nessa circunstância, a solução encontrada pelos governos é empregar a demanda de trabalhadores disponível "em obras públicas com milhares de sertanejos empregados em serviços como a construção de açudes, pontes e estradas de ferro" ${ }^{24}$.

Percebemos o favorecimento do estado em se valer da mão de obra alocada nas obras de socorro espalhas pelo Ceará e cujas regiões foram citadas neste trabalho, população esta que durante muitos meses viveu da distribuição diária de farinha, que era insuficiente comparada às necessidades da população naquele momento.

As medidas de socorros com as obras públicas eram apresentadas como meio eficaz de amparo aos retirantes, sendo uma forma de controlar as constantes migrações e desaglomerar multidões desesperadas que passavam a ocupar os centros urbanos e ordenar as massas sertanejas. Mantendo-as dentro dos parâmetros da elite política é possível entender as proporções da

64 calamidade e demonstrar a profundidade da política de socorro aos flagelados através do trabalho durante a seca. Num cenário em que as obras eram incapazes de ater com salários dignos, enormes grupos de retirantes eram deixados sem rumo nas estradas pela própria seca.

24 SOUSA, José Weyne de Freitas. Política e seca no Ceará (1869-1905). In: XXV SIMPÓSIO NACIONAL DE HISTÓRIA, 2009. Fortaleza, p. 7. 


\title{
6. Entre fanáticos e cassacos: a presença da Irmandade da Cruz nos sertões do norte do Ceará (1900-1903)
}

\author{
Raimundo Nonato Fernandes ${ }^{1}$
}

\section{Introdução}

O presente trabalho parte de uma investigação e toma por objeto uma leitura acerca do surgimento da Irmandade da Cruz da Vila do Massapê e dos eventos que culminaram com o massacre que se deu em 26 de março de 1902, às margens do açude público Acaraú-Mirim. Analisaremos os fatos à luz do método de pesquisa que visa refletir e entender como foi possível que estes acontecimentos escaparam a um estudo mais aprofundado de nossa historiografia. Buscamos, portanto, recuperar uma memória e trazer presente em nossa abordagem, a partir dos ecos trazidos por uma nova história, ouvindo os gemidos, os gritos e os apelos daqueles que foram massacrados e silenciados e que agora reivindicam e merecem nos dias atuais o direito à memória histórica. Por fim, levanta inquietações sobre esses eventos, tentando estabelecer relações com outras Irmandades da Cruz que existiram nos Sertões do Ceará, refletindo a partir daí suas semelhanças e disparidades; e quais as motivações que existiam entre a Irmandade da Cruz, a Légio Crucis e a Irmandade do Caldeirão da Santa Cruz, para se pensar a sua importância no âmbito da construção histórica como estabelecimento de uma memória viva e atuante em nossos dias.

A partir desse estudo que hora realizamos, podermos afirmar que a Irmandade da Cruz, como objeto de nossa análise, se coloca para nós dentro de uma perspectiva e de uma oportuna necessidade de construir uma narrativa plausível e coerente acerca dos eventos ocorridos entre a seca de 1900 ao ano 1903, mais especificamente na construção do açude AcaraúMirim, obra pública do Departamento Nacional de Obras Contra as Secas (DNOCS). Procuramos mostrar sua importância e relevância histórica para a região, já que esta foi desconsiderada e desconhecida por muitos naquela região, sua análise serve para também entender como se deu a construção das relações que existiam entre as populações sertanejas, e as estruturas de poder, as mentalidades e o pensamento que moldaram essas populações e 
suas relações sociais, sobretudo do ponto de vista do sentimento religioso, que impulsionaram esses atores sociais em suas práticas religiosas e o caráter político e social dos grupos e movimentos que atuaram de forma dinâmica a partir daquele lugar social.

\section{A Irmandade da Cruz e sua gênese}

Sabe-se muito pouco sobre os detalhes da existência da Irmandade da Cruz do Massapê. No entanto, o que se sabe foi feito como construção histórica partir da historiografia oficial escrita pelo historiador cearense Guilherme Studart ${ }^{2}$, conceituado membro do Instituto do Ceará. Este relato faz menção à existência dessa irmandade uma única vez, quando de seu desfecho, omitindo e selecionando alguns dos detalhes ligados a esse acontecimento. O que se sabe, no entanto, é que ela de fato existiu igualmente a outras existentes na região norte do estado ${ }^{3}$, mesmo não sendo tão expressiva como a outra surgida o sul do Ceará, num outro período, a Irmandade do Caldeirão da Santa Cruz do Deserto, em 1932, e que teve como principal liderança o beato José Lourenço.

Sabemos, por outras fontes históricas e narrativas orais distintas, que as duas irmandades passaram a existir em diferentes épocas e também tiveram processos de formação e engajamentos de seus líderes de formas diferenciadas. O que podemos afirmar até aqui é que ambas passaram por processos semelhantes na forma de se organizarem e também na maneira como eram vistas pelos diversos grupos à época, passando desde uma visão preconceituosa e estigmatizada por parte da sociedade e da elite política local. Graças ao contexto e mentalidade da época, isso possibilitou um processo de marginalização, e que se tornou algo comum na época, ao associar fanatismo religioso ao banditismo, como fenômenos que fugiam aos padrões de uma racionalidade e ao ideário de ordem social. Logo, essas populações tornaram-se sinônimos subversão e desvio da ordem estabelecida.

O fanatismo transformou-se numa característica pejorativa das práticas religiosas dos pobres. O fanatismo, atribuído aos despossuídos, tornou-se também uma desculpa para a repressão aos movimentos populares. Fanatismo, na perspectiva das

\footnotetext{
Guilherme Studart descreve no livro Datas e fatos da história do Ceará; a única e importante fonte documental da existência da Irmandade da Cruz do Massapê, quando do seu desfecho com o massacre orquestrado pelo governo por força policial, em 25 de março de 1902 nas margens do açude público Acaraú-Mirim na Vila do Massapê.

3 Outros estudos mostram que existiram várias irmandades iguais à Irmandade da Cruz do Massapê, como a Legio Crucis no povoado de Varjota, da vila do Ipú; a da localidade do Riacho dos Guimarães, próximo de Sobral; em Carnaubal, município de São Benedito, na Serra da Ibiapaba. Sobre isso ver nota de SILVA JÚNIOR, Agenor Soares. Cidades Sagradas. Da "Roma cearense” à "Jerusalém sertaneja”: A Igreja Católica e o desenvolvimento urbano do Ceará (1870 - 1920) Sobral e Juazeiro do Norte. $1^{\text {a }}$ Edição. Fortaleza: Edições ECOA, 2015, p. 250.
} 
elites, era um atraso cultural que deveria ser combatido em nome da ordem do progresso. Era uma característica de mentes atrasadas que por não raciocinarem normalmente, eram perigosas ao "bom funcionamento da sociedade" 4.

Dentre muitos fatores responsáveis pelo surgimento dos movimentos messiânicos, e que também estava associado ao seu crescimento, como potencializador dessa realidade de exclusão social, é que eles estavam ligados ao drama do abandono em épocas de seca, algo que historicamente fazia parte da cultura do Nordeste e estava diretamente associada a essa realidade de desespero com que passavam essas populações pobres, muitas vezes jogadas à própria sorte por parte dos fazendeiros, bem como por parte dos poderes públicos nas épocas de estiagem. Surgiram, no entanto, outros fatores e elementos que foram sendo potencializados como resposta a essa exclusão, como por exemplo, o messianismo e o banditismo, algo tão comum e vivenciado junto às populações sertanejas, principalmente naqueles períodos de grandes secas. "O caminho ainda mais curto e mais rápido era o do fanatismo ou em outros casos o cangaço como forma de libertação na esperança de alcançar os urgentes milagres. Era só rezar e ter certeza que a salvação viria por acréscimo" 5 .

Movimentos religiosos e de caráter social como os de Canudos, no final do século XIX, e de Pau de Colher, nos sertões da Bahia e, posteriormente, o de Caldeirão no Cariri cearense, tornaram-se uma constante, onde a ajuda paternalista dos coronéis e chefes locais não mais podiam chegar, e a ausência do estado e das instituições deixavam uma lacuna diante do abandono e desamparo dessas populações em épocas de privação e de fome, sendo naturalmente substituídos por lideranças que exploravam pelo desespero e pelo catolicismo popular como resposta e solução imediata aos anseios e angústias daquela dura realidade com que estavam acostumados a viver. Logo, "funciona", não raramente, como uma espécie de resposta do sistema simbólico do camponês à dureza e dificuldade da vida. As coisas religiosas, espirituais, muitas vezes nascem e desenvolvem-se com "uma certa influência das condições materiais da vida"6.

A Irmandade da Cruz de Massapê, na região noroeste do Ceará, também foi potencializada graças a essas condições. Serviu de espaço e como centro catalizador das angústias e dos anseios dessa gente humilde e simples e sem perspectivas de melhoria de vida e que buscavam na organização e no conjunto de práticas, vivenciar o mais próximo possível de uma vida comunitá-

RAMOS, Francisco Régis Lopes. Caldeirão, estudo histórico sobre o beato José Lourenço e suas comunidades. 2 ${ }^{\mathrm{a}}$ Edição. Fortaleza: Edições Instituto Frei Tito de Alencar, p. 39.

THOMAZ NETO, Antônio Thomaz. A Irmandade da Cruz. $1^{\text {a }}$ Edição. Fortaleza: ABC Editora, 2007, p. 89.

6 Id. Ibid., p. 88. 
ria inspirada nos ensinamentos do Evangelho e nas práticas das bem aventuranças, em valores como a caridade, a solidariedade e o amor ao próximo. No entanto, essa irmandade constituiu-se em termos legais, de certa forma, de maneira espontânea e um tanto marginal do ponto de vista jurídico, haja vista que funcionava quase que de forma clandestina. Mas ao que parece, estava regulamentada pelos Estatutos da Ribeira do rio Acaraú-Mirim, que também permitia seu funcionamento sob a vigência da Carta Magna de 1891. "Na região norte do estado sentia-se alguns ecos desses movimentos: Irmandade da Cruz, em São Benedito e Massapê, ou a Légio Crucis em Ipú; foram movimentos religiosos contestatórios de lideranças que contaminavam as populações da região, organizados pelos estatutos da ribeira do rio Acaraú-Mirim e da nova Carta Magna de 1891" 7.

Nota-se que não diferente das suas congêneres do norte e do sul do estado, tinham muitas de semelhanças entre elas, haja vista pela dinâmica e pela forma como acolhiam seus membros, bem como pela maneira como se dava a sua forma de organização e seus objetivos. Também do ponto de vista religioso e social, bem como das práticas e vivências onde predominava 0 espírito caritativo e fraterno em seu meio. Quanto do ponto de vista social, estas irmandades prestavam importantes serviços aos desamparados, e principalmente aos flagelados e famintos da seca.

Irmandade da Cruz tinha dentre outros objetivos - o de praticar uma fraternidade e uma solidariedade sem limites, amparar e socorrer os retirantes famintos da grande seca de 1900, como luta libertária de uma comunidade de flagelados da seca, além de expicaçar todas as repartições dos poderes governamentais, federais, estaduais e municipais, sem chegar a agressividade da ruptura ${ }^{8}$.

No que se refere à participação de seus membros, e a sua adesão voltavam-se às atividades de cunho comunitário, visto que em geral e na sua totalidade, esses pobres sertanejos eram marginalizados tanto do ponto de vista social quanto religioso, e buscavam nesses espaços o amparo e o refúgio para seus flagelos frente ao abandono da sociedade e dos poderes públicos. "A esperança de alcançar dias melhores, em suas súplicas ao céu nos momentos de maior miséria e sofrimento de uma população de famintos, era de fácil adesão, visto que os poderes públicos constituídos e espirituais eram totalmente omissos".

Logo, a vivência fraterna possibilitava uma prática que envolvia ações comunitárias relacionadas a essa vivência de práticas religiosas e uma cons- 
ciência para uma organização para a vida comunitária. Tornaram-se uma alternativa para superar o isolamento e o abandono pelo qual muitos passavam diante dos flagelos da seca, nos momentos de privação e fome, em decorrência das rigorosas e sucessivas estiagens no período das secas. Esse modelo de vida comunitária era quase que um padrão a ser seguido nessas comunidades sertanejas, práticas essas que também foram vivenciadas na comunidade do Caldeirão do beato José Lourenço: "Não se pode esquecer, nesse sentido, a ligação entre a organização social da comunidade e o fator religioso. Todos se consideravam católicos e as práticas sagradas não eram algo inédito no 'Nordeste'. Tudo feito por lá era comum em vários lugares do sertão"10.

Busquemos compreender como num momento tão conturbado, como a seca e a fome foram capazes de aglutinar populações sertanejas que, diante daquela situação, estão abandonadas à própria sorte, visto que a seca, sendo um fenômeno natural, tem uma incidência desde os tempos mais remotos sobre toda a região semiárida brasileira, e se tratando de um fenômeno natural, foi entendida e tratada de formas diferentes conforme os interesses de grupos políticos e econômicos e de acordo com seus objetivos.

A questão da influência do meio era a grande arma política do discurso regionalista nortista, desde que a seca foi descoberta em 1877, como um tema que mobilizava, que emocionava, que podia servir de argumento para exigir recursos financeiros, construção de obras, cargos no Estado etc. O discurso da seca e sua "indústria" passaram a ser a "atividade" mais constante e lucrativa nas províncias e depois nos Estados do Norte, diante da decadência de suas atividades econômicas principais: a produção açúcar e algodão ${ }^{11}$.

Como resultado desse contexto político, social e religioso, é importante observar o caráter agregador com que essas populações buscaram em certa medida se identificar com essas irmandades ou outros grupos ou formas de assimilação e adequação ao meio, frente à situação em que muitos sertanejos se encontravam. Esse modo de agir está associado a dois fenômenos muito comuns e amplamente estudados por pesquisadores e estudiosos que se detiveram a entender o Nordeste. Foi a partir do fenômeno da seca e suas consequências que explicava o afloramento de movimentos ligados tanto ao messianismo quanto ao banditismo e, a partir deles, todas as outras causas possíveis diante do desprezo e do abandono com as quais as populações sertanejas estavam submetidas.

RAMOS, Francisco Régis Lopes. Caldeirão, estudo histórico sobre o beato José Lourenço e suas comunidades. $2^{\text {a }}$ Edição. Fortaleza: Edições Instituto Frei Tito de Alencar. 2015, p. 84.

11 ALBUQUERQUE JÚNIOR, Durval Muniz. A Invenção do Nordeste e outras artes. $5^{\mathrm{a}}$ Edição. São Paulo: Cortez Editora, 2011, pp.71-72. 
Para fugir desse flagelo e abandono, as populações sertanejas buscaram se adaptar das mais diversas maneiras, tanto à indiferença das elites locais, quanto ao isolamento e desprezo com que eram vistos pelas populações das cidades e dos grandes centros urbanos ligados ao sul, tido como mais moderno, civilizado e promissor. Isso fez com que esses grupos subordinados reagissem à sua maneira e das mais diversas formas, e até da mesma forma com que eram tratados, ora com violência, ora com indiferença; o que justifica algumas reações diante desse quadro:

As manifestações de descontentamento dos dominados, como o banditismo, as revoltas messiânicas e mesmo o atraso econômico e social da área são atribuídos à seca, e o apelo por sua solução, torna-se um dos principais temas dos discursos regionais ${ }^{12}$.

Foi a partir desse período, da grande seca de 1877, e em razão do pretexto de socorrer suas vítimas, que a elite política e econômica local conseguiu, diante desse pretexto, encampar uma intensa mobilização para obter recursos financeiros para realizar a construção da Estrada de Ferro Camocim-Sobral.

\begin{abstract}
A notícia da iniciação da mencionada obra, que avançava veloz do litoral à hiterlândia, ecoou logo nas abas da Meruoca, e nas ribeiras do baixo Acaraú, trazendo a Massapê crescido número de serranos e sertanejos que, reduzidos a extrema penúria, procuravam recursos para o sustento próprio e dos filhos na eminência de sucumbirem de inanição ${ }^{13}$.
\end{abstract}

A partir dessa justificativa de socorrer os flagelados da seca foram realizadas muitas obras nas frentes de serviços, havendo uma necessidade de transportar mantimentos para os socorros. Havia o risco constante de saques aos comboios de alimentos, que tanto serviam para pagamento pelo trabalho aos chamados cassacos, como para a distribuição para aquelas populações famintas. Houve diversas obras públicas de socorros aos flagelados já no período da seca de 1877, como foi o trabalho de construção daquela estrada de ferro, bem como outros nesse período, e que se arrastou até 1882 com a finalização daquele trecho.

Desde a seca de 1877 até o ano de 1900, as mesmas medidas foram tomadas, e outras obras públicas foram se intensificando, sobretudo nos períodos de seca na medida em que iam se prolongando com mais rigor, prejudican-

13 AGUIAR, Osvaldo. Massapê em Foco. 1a Edição. Imprensa Universitária do Ceará - UFC, 1969. Ob. Cit., p. 14. 
do as economias das pequenas cidades e interferindo na rotina das pessoas, "[...] o Ceará vinha sofrendo com problemas climáticos. Estiagens assolavam o Estado desde 1900. O rigoroso inverno acontecido em 1899, por exemplo, foi sucedido por uma seca que desarticulou a economia estadual" ${ }^{14}$. Ao longo dos anos, foram sendo mobilizadas as forças políticas locais, em campanhas de caráter humanitário, exigindo por parte dos poderes públicos a criação de mais obras, algumas sem qualquer planejamento quanto a sua eficácia e objetivos a serem alcançados.

Ao tempo em que, nos períodos de seca, era montada uma estratégia de programas salvacionistas, tudo era interrompido caso no ano seguinte as precipitações voltassem.

Foi o caso do ano de 1901. Ao cair uma boa quantidade de chuvas no Estado, automaticamente, o Governo Federal suspendeu a composição dos grupos de engenheiros que se preparavam para exercer melhoramentos nas estradas de ferro de Sobral e Baturité, bem como a construção de açudes e obras de assistências que se faziam pela verba de socorros públicos ${ }^{15}$.

Logo, muita gente que precisava dos Socorros Públicos em tempos de calamidade passou a depender dessa ajuda para garantir a sua sobrevivência, outros tiraram proveito o quanto puderam, beneficiando-se de todas as formas, criando uma rede de colaboração e desvios, desde aquele que controlava a distribuição dos mantimentos na hora do pagamento pelos trabalhos, passando pelas mãos do atravessador e indo parar na do comerciante ganancioso e corrupto, que vendia o produto de pior qualidade, superfaturado. "As migalhas eram convertidas, no que pior existissem, em farinhas de mandiocas mofadas, carnes-secas ardidas, quase podres, feijão com gorgulhos, milho com carunchos a ainda superfaturados"16 , até chegar no líder político que obviamente fazia disso uma oportunidade de angariar votos em épocas de eleição, distribuindo as vagas aos apadrinhados políticos.

Estes mandatários e favorecidos por essa rede de conexão, não estavam preocupados em atender às necessidades dos flagelados, pois tinham somente a finalidade de favorecer a elite política local, possibilitando que alguns pudessem se utilizar desse expediente ao solicitar constantes pedidos de mais recursos para conclusão dessas obras.

14 SILVA JÚNIOR, Agenor Soares. A Sobral de 1920: a metrópole do sertão? In: SANTOS. Carlos Augusto Pereira dos, ALENCAR. Alênio Carlos Noronha. A Polifonia Sobralense. Leituras e entendimentos sobre a história da cidade, p. 103.

15 SANTOS, Op. cit., p. 103.

16 THOMAZ NETO, Op. cit., p. 48. 
Era assim que chegavam socorros aqueles que deveriam por direito receber os alimentos, depois de naturalmente filtrado por outros interesses além dos famélicos - dos políticos - na verdade, prevalecia na época a trindade da maldição: corrupção, seca e inflação ${ }^{17}$.

Foi isso que a Irmandade da Cruz denunciou muitas vezes, tornando-se talvez, a partir daí, alvo de hostilidades e perseguição, tanto por parte dos mandatários da política local como dos governos, quanto da Igreja Católica, que via com desdém e preocupação esses movimentos religiosos, com relação à irmandade e a outros movimentos messiânicos de luta camponesa ${ }^{18}$. Tratados com hostilidade, esses movimentos populares não eram vistos com bons olhos, pois colocavam em risco o estabelecimento da ordem social e religiosa. "Os poderes públicos constituídos procuraram aplacar rapidamente tais movimentos, podendo ser entendido como falta de força do Estado nos sertões, combatendo tais manifestações de fanatismo que operavam em algumas localidades"19.

Portanto, esses movimentos atrapalhavam interesses dos que se beneficiavam desse esquema, já que foi criada, assim, uma rede de favorecimento e de desvios dos tão poucos recursos que essas obras recebiam, resultando em que nesses períodos de calamidade pública não houvesse qualquer planejamento, fazendo com que essas se estendessem por longos prazos, e se impregnasse na cultura do Nordeste, "um amplo sistema de controle dos donativos, por parte de funcionários, antecipava, assim, aquilo que ficou conhecido por "indústria da seca", tão comum no século XX"20.

\section{Cassacos: gente de fé entre o trabalho e a oração}

Foi nesse contexto histórico e nesse caldeirão cultural que a Irmandade da Cruz de Massapê existiu igualmente às outras da época. Dos seus quadros faziam parte os chamados desclassificados, gente simples, gente religiosa e desamparada pelos poderes públicos e abandonados à própria sorte, e que depositavam muitas vezes as suas últimas esperanças numa fé ingênua e num

17 THOMAZ NETO, Op. cit., p. 48.

18 Lilia Schwarcz descreve o grande movimento messiânico de Canudos, que juntamente com outros movimentos surgidos a partir da nova República, tornaram-se movimentos não só de caráter religioso mais também tiveram um caráter político e social; principalmente em relação à contestação do latifúndio como forma de exploração dos agricultores empobrecidos, diante da concentração da terra e de poder pelas oligarquias locais, fazendo com que o Estado reprimisse tais movimentos com extrema violência. Cf. SCHWARCZ. Lilia M. e Heloisa M. STARLING. Brasil: uma biografia. Companhia das Letras, São Paulo. 2015, p. 332, 334.

19 SILVA JÚNIOR, Op. cit., p. 251.

20 NEVES, SOUSA, Simone de. Uma nova história do Ceará. A seca na história do Ceará, NEVES, Frederico Castro. 4a Edição. Fortaleza: Edições Demócrito Rocha, 2015, p. 84. 
modelo de religiosidade pouco racional, mas que era mais prático e usual, bem como de um espírito caritativo extremado, confiando às irmandades e a seus líderes a responsabilidade sobre os demais membros, numa conjunção de forças capazes de minimizar o sofrimento e abandono.

Essas irmandades praticavam, na verdade, um catolicismo popular, com crendices e superstições misturados com ritos afros em que Maria, a Mãe de Jesus, era venerada como a quarta Pessoa da trindade, porque não havia outro meio de salvação a não ser vinda do céu. A Irmandade da Cruz fundada em Massapê cuidava mais da salvação do corpo do que da alma, por representar uma luta libertária, de um punhado de sertanejos trabalhadores rurais, reunidos em uma associação civil, em que a solidariedade para com o irmão flagelado era o seu maior empenho, o que a tornava diferente das demais seitas ${ }^{21}$.

Esses grupos de populações sertanejas, que na sua grande maioria eram constituídos de caboclos sertanejos expulsos da terra, alguns eram moradores das fazendas, todos pequenos agricultores abandonados pelos fazendeiros que não podiam mais dar conta de ajudar seus antigos moradores:

A proteção oferecida pelos proprietários não chega a sequer amenizar as dificuldades... O "dever de proteção", parte integrante da reciprocidade desigual das relações paternalistas, passa a ser exercido pelo Estado, na impossibilidade de o exercerem os próprios proprietários ${ }^{22}$.

Podia-se deduzir que também tinha uns poucos proprietários de terras, muitos deles oriundos das fazendas das redondezas e que estavam, assim como muitos agora, abandonados e dispersos pelo sertão adentro em fluxos migratórios sazonais causados pelos períodos das constantes secas. Muito desses sertanejos eram oriundos de vários lugares, vindos das mais diversas situações, moradores das fazendas, os caboclos mestiços, como resultado da miscigenação da população indígena com o branco, e negros trazidos para o trabalho nas fazendas de gado, também ligados a outras atividades de produção agrícola, e que sofreram o flagelo e os constantes efeitos causados pelos ciclos periódicos de estiagem, registrados não só naquele ano, mas desde os anos que antecederam a seca de $1900^{23}$, interferindo nas vidas dos

21 THOMAZ NETO, Op. cit., p 34.

22 THOMAZ NETO, Op. cit., p. 81.

23 Cf. MAESTRI, Mário, MACEDO, José Rivair. Belo Monte, uma história da Guerra de Canudos. $1^{\text {a }}$ edição. São Paulo: Editora Expressão Popular, 2004, p. 66. Ao falar em ciclo de secas no sertão nordestino e que assolava periodicamente as populações rurais e que foram registradas desde 1710-1711,1777$1778, \ldots 1877-1879$ e 1889-1889; segundo o autor, se coloca em ciclos iguais aos registrados nas secas de 1900 ao ano de 1903, à época do surgimento e extermínio da Irmandade da Cruz de Massapê. 
sertanejos em todos os seus aspectos, já que as atividades agrícolas foram significativamente afetadas com prejuízos materiais e vidas humanas.

\begin{abstract}
No semi-árido, a produção inteiramente destruída, os moradores consomem as suas últimas sementes e, aos poucos, mas numa onda irresistível, vão deixando para trás seus casebres e suas terras arrendadas. Saem famintos de seus lares e começam a vaguear pelos caminhos e estradas em busca de auxílio. O caminho da capital cedo transformará na única opção para a sobrevivência: os moradores das fazendas de criar transformam-se em retirantes ${ }^{24}$.
\end{abstract}

Em razão desse grande fluxo migratório dos retirantes da seca, tanto o governo do Império quanto o da chamada Nova República criaram medidas e ações, como as chamadas ações de emergências da secas, que eram as frentes de serviço, de caráter paliativo e que na maioria das vezes aconteciam nos períodos de estiagem, mas que depois, na medida em que voltava a chover, eram interrompidas, criando um círculo vicioso e que não tinham nenhum efeito prático e nenhuma vontade política de resolver o problema da seca, visto que, na maioria das vezes, os grupos políticos locais se beneficiavam desses mecanismos para angariar votos e determinar via relações de apadrinhamento e intensa dependência paternalista, o que significava uma dependência do sertanejo em relação aos coronéis e líderes políticos. Aos flagelados, restava buscar trabalho nas obras públicas de construção de estradas, açudes, cemitérios e outros trabalhos de assistência, ao menos para garantir comida no mínimo necessária para sobrevivência:

A escassez de chuvas, inviabiliza a produção de subsistência de vaqueiros e pequenos moradores, levando-os coletivamente a uma ruina sem precedentes que jamais conseguiria ser amenizada pela caridade das famílias abastadas do campo, nem pelo senso de dever paternalista de proteção por parte dos coronéis, muito ciosos de seu campo de domínio político... ${ }^{25}$.

"Era preciso proteger a cidade das 'invasões' periódicas dos refugiados da seca"26, sendo as obras hídricas de construções de barragens uma das alternativas viáveis para exercer esse controle social, cumprindo um dos seus objetivos imediatos que era no sentido de manter essas populações ocupadas e longe das cidades. Logo estas obras foram se viabilizando na medida em que serviam também a interesses políticos locais recebendo contingentes de recursos para os trabalhos.

\footnotetext{
NEVES, Op. cit., p. 81.

25 NEVES, Op. cit., p. 81.

26 NEVES, Op. cit., p. 86.
} 
Dentre essas obras públicas, que no começo do governo republicano receberam recursos para sua construção, estava relacionada a do açude Acaraú-mirim que, naquele ano, recebeu crédito para a construção ${ }^{27}$.

A tão esperada obra pública da construção da barragem do Acaraú-Mirim fez aumentar a esperança dos sofridos retirantes que vagavam sertão adentro em busca de trabalho, comida e abrigo, "Numa epopeia de verdadeiro êxodo de miseráveis, rostos e famintos, mais parecido como uma retirada dos exércitos de derrotados, pela inclemência do tempo e pela demora de socorros dos homens do poder" 28 . Com a notícia da construção do açude, bem como da necessidade de um grande contingente de trabalhadores para tocar a obra, grande parte de mão de obra ociosa recorreu às frentes de serviço das obras que foram iniciadas oficialmente em 1901, e ficou a cargo do engenheiro sobralense João Thomé Saboya e Silva, passando deste para o também engenheiro José Aires de Sousa, natural de Santana do Acaraú, este provavelmente deve ter sido o responsável técnico pelo projeto à época do massacre de 26 de março de 1902, já que ele ficou como engenheiro responsável até 1903, sendo transferido para Quixadá nos trabalhos de reflorestamento da bacia do açude Cedro.

É fato que antes mesmo de iniciar a construção, se deslocassem até os canteiros de obras daquele açude grupos de retirantes famintos e flagelados pelo sofrimento e abandono do longo percurso e que encontraram abrigo no amparo solidário da Irmandade da Cruz.

A irmandade por todos os seus membros e socorridos, trabalhavam ativamente em rebanhar sobreviventes retirantes dos caminhos e veredas; que em certo momento chegavam a se amontoar em multidão - acolhendo-os em abarracamentos de concentrações, latadas e palhoças cobertas de folhas de mofumbo, oiticica e palha de carnaúba, num triste canteiro da futura obra, onde o governo federal prometia construir o açude Acaraú-Mirim, a princípio, em grande parte, migalhas verbas dos Socorros Públicos, no valor de Rs. $180.000 \$$, a um custo final ao que se diz, de Rs. 1.200.000\$ ao preço da época ${ }^{29}$.

Esses recursos eram pouco significativos frente aos muitos que buscavam uma oportunidade de garantir ao menos comida para se alimentarem e aos seus familiares, visto que, junto com toda sorte de gente, vieram famílias inteiras em busca de meios de sobrevivência e face ao desespero, que busca-

27 SOBRINHO, Thomaz Pompeu. História das secas: Século XX, 2a Edição. Mossoró. Assembleia Legislativa do Rio Grande do Norte/Fundação Guimarães Duque/Escola Superior de Agricultura de Mossoró, 1982. Sobre o contingenciamento de recursos enviados para a construção da Barragem do Acaraú-mirim, bem como de seu início foi descrito na grandiosa obra literária de Thomas Pompeu Sobrinho.

28 THOMAZ NETO, Op. cit., p. 43.

29 THOMAZ NETO, Op. cit., p. 43. 
vam nessas frentes de serviço ao menos obter uma ração de alimento pelo trabalho diário. Relatos contam que recebiam no valor de seu trabalho uma ração de alimentos, já que naquela época era escasso o dinheiro e também de pouca circulação.

Naquele tempo era comum nos canteiros de obras, e antes mesmo desses recursos e mantimentos chegarem à distribuição como pagamentos das obras, os desvios e enriquecimento praticados por políticos, comerciantes, atravessadores, supervisores das obras, os chamados apontadores, assim como também eram constantes a falta no fornecimento dos alimentos, justificados ora por cortes de verbas, ora pelo seu extravio em razão das condições de transporte e de estoque inadequado dos barracões onde estes mantimentos eram guardados, ao risco de desvio de sua verdadeira destinação.

Sobre essas condições, a Irmandade da Cruz se colocou como empecilho ao mandonismo local, denunciando essas práticas bem como cobrando maior assistência aos pobres flagelados, se colocando como a única talvez, o mais coerente e eficiente mecanismo de cobrança, apontando o dedo na ferida de uma classe que sem nenhum escrúpulo cometia o crime do roubo e, em consequência, deixava morrer a muitos de fome, desviando comida das muitas bocas que padeciam de inanição e doenças causadas pela fome.

\begin{abstract}
A Irmandade da Cruz só podia incomodar e muito aos donos do poder na época - foi ela, pelos seus líderes que tiveram a coragem de denunciar os gritos, os desmandos e as omissões cometidas contra os flagelados, famintos e retirantes, pelas Comissões de Socorro, não nos tribunais públicos, como de direito legítimo por falta de alguém que por ele defendessem o direito à vida, conforma dizia Rodolfo Teófilo, mas no tribunal das suas consciências, que, por mais insensíveis que fossem eram feridos como o ferro em brasa e sangravam inexoravelmente até a morte moral ${ }^{30}$.
\end{abstract}

Logo, este grito de denúncia que a Irmandade fazia era levado a cabo por seus líderes, chegando ao conhecimento público de todos que participavam de suas procissões e encontros, e escutavam nas prédicas de seu maior líder, um certo Damião, natural da redondeza da barragem do açude Acaraú-mirim. Este grito de denúncia tinha um peso moral significativo, visto que vinha acompanhado de verdadeiros gestos de compromisso e caridade, testemunhados pela dedicação e empenho dos membros da irmandade em ajudar os famintos e abandonados, já que esta era uma forma como a irmandade praticava a caridade junto aos pobres e mais sofridos, o que a colocava como a única organização de credibilidade ao apresentar suas denúncias de desvios dos poucos recursos nas obras de socorros públicos.

${ }_{30}$ THOMAZ NETO, Op. cit., p. 54. 
A árdua e difícil tarefa em que se propunha a Irmandade da Cruz, que juntamente com os irmãos crentes: Furtado, de Cabaceiras, Campelo de Sobral, Veado de Monsenhor Tabosa, Felipe, e outros, que se encontravam quase que semanalmente na grande feira livre localizada na praça maior da Estação do Trem em Massapê, onde comercializavam seus produtos agrícolas, e que na seca de 1900, nada vendiam e nada compravam, e ainda o pouco que tinham davam de esmola aos flagelados - não podiam deixar de atender as mãos esquálidas e sujas estendidas, implorando uma esmola pelo amor de Deus para ele pedinte, mulher e numerosos filhos, há três dias sem nada comerem...sem ninguém mais a apelar, daí a congregação dos flagelados numa associação de sertanejos produtores rurais ${ }^{31}$.

Garimpando entre o cascalho da memória e do esquecimento, recolhi como preciosidade um fragmento de um tesouro inestimável: o depoimento do senhor Raimundo Nonato Costa, conhecido por apelido Dadiu. Ele é um dos descendentes de um dos muitos retirantes que vieram trabalhar no canteiro de obras do açude Acaraú-mirim. Seu avô chamava-se Vicente de Pinho e que viveu por mais de um século e morou em Massapê, na região da atual Várzea da Cruz, que é o local de onde parte as narrativas dos primeiros retirantes, e dos cassacos que vieram para trabalhar na construção do açude em 1902, e de onde provavelmente partiram as poucas memórias da época da Irmandade da Cruz e de seus membros. Vicente de Pinho, seu avô, como seu Dadiu nos narrou em entrevista, contava histórias de quando trabalhou no açude e que ouvia também dizer, que o avô veio de Camocim e seu avô, chegando a Massapê seu avô, procurou trabalho na construção do açude.

Meu avó apareceu aqui [Massapê]... Ele veio de Camocim pra cá, ele veio solteiro, aí apareceu aquelas secas terríveis. Esse açude aí estava em construção, aí meu avô trabalhou lá, tinha comboio de jumento; as mulheres, tinha gente que carregava terra dentro de uma cuia, acredita? Dentro dos sacos, na padiola pra carregar... Ele me contava tudim, sabe? Ele trabalhou muito tempo no açude do Mirim, até terminar... Esse açude, não sei se foi feito duas vezes ou foi três vezes. Na minha lembrança eu sei de duas, mas pode ser três... Aí pra eles receber dinheiro... Dinheiro não, não tinha dinheiro, era mercadoria. Ia recebendo mercadoria e iam se alimentando, iam tirando o tempo, sempre meu avô me contava essa história te desse açude aí... O nome do meu avô é Vicente de Pereira da Costa, era conhecido como Vicente de Pinho, apelido também, mas o nome certo era Vicente Pereira da Costa, não tinha nada de Pinho, ele pegou esse negócio de Pinho porque ele casou com minha avó, de dependência de Pinho, daqui da serra [Meruo- 
ca]... que também já viero de lá pra escapar através desse açude, sabe, se casou-se, aí ele morou e aí e terminou a vida toda dele aqui no Massapê, morreu aqui...102 anos" ${ }^{\prime \prime 2}$.

Igualmente a outras situações que já existiam desde muito tempo, no canteiro de obras da construção da barragem do Acaraú mirim não há registros e nem tampouco relatos orais de que houvesse uma prática de segregação social em relação a esses grupos de flagelados diante da sociedade massapeense, mesmo que houvesse um certo receio e o iminente risco de saques no comércio local, roubos e assaltos que comumente se praticavam nas brenhas do sertão nas épocas de secas. Mas o que de fato existia era a visão estereotipada e preconceituosa com que os pobres flagelados eram tratados, bem como a forma discriminatória e pouco caridosa com que os pobres esfomeados e o trabalhadores eram tratados pelos chefes do canteiro de obras em razão do pagamento pelo trabalho, relato confirmado tanto pelo senhor Dadiu quanto pelo escritor massapeense Antônio Thomás Neto:

\begin{abstract}
A ração, administrada pela comissão de socorros públicos que era dada em troca de algum trabalho, remunerada sob o parâmetro da moeda local de circulação restrita ao canteiro de obras do açude, chamada - sungelo, que na verdade era um vale de papel, mais valioso que dinheiro, porque comprava comida, outras vezes a comida era até tomada das mãos das comissões de socorro que sonegava de maneira impiedosa, mas não passava de uma esmola ${ }^{33}$.
\end{abstract}

Com relação aos conhecidos abarracamentos, que eram os canteiros de obras ou alojamentos usados pelos flagelados nos trabalhos das obras públicas, eles se diferenciavam em pouco dos já conhecidos "campos de concentração" existentes desde a grande seca de 1877, tendo as mesmas práticas da política de segregação e controle social que ficaram famosas a partir da utilização desses campos para separar aqueles que eram considerados desclassificados, e tratados como bichos, os famosos "cassacos" ${ }^{4}$, termo que se tornou comum em outras secas, como as de 1915 e 1932. "Há, então, pelo menos três aspectos de controle social: o cercado que servia de prisão, o tra-

32 Raimundo Nonato Costa (Dadiu). Entrevista realizada pelo autor em 26 de setembro de 2018, dia de São Damião, 158 anos depois do nascimento do líder da Irmandade da Cruz de Massapê. Nessa entrevista, ele descreve a história de seu avô, retirante vindo do Camocim para trabalhar nas obras de construção do açude Acaraú-mirim em 1902.

33 Cf. THOMAZ NETO, Op. cit., p. 49-50. Grifo do autor.

34 Cassacos, termo usado na literatura e em outros autores, cf. MELO, Francisco Dennis Os deserdados da seca, "a esteira movediça dos retirantes" carrega a marca em sua vida, que vai além do corpo fragilizado pela seca, que vai além do aspecto mais visível da fome”. Nas trilhas do sertão: escritos de cultura e política nos interiores do Ceará. Volume 2. No fundo a cozinha me inquieta”: entre a falta e a fartura no romance Cassacos, de Cordeiro de Andrade. Sertão cult Editora. Sobral, 2015, p. 41. 
balho nas estradas e nas construções de palhoças e o fato de o campo ajuntar gente, a fim de não haver invasão das cidades pelos famintos" ${ }^{35}$.

Esses locais de concentração dessas populações serviam, sobretudo, para afastar os flagelados, pedintes e toda pobre gente do comércio das cidades, num processo de contenção e higienização dos indesejáveis retirantes que viessem a ocupar os espaços públicos, destinados aos cidadãos de bem e que não poderiam nunca conviver com essa gente miserável e fedida, já que este era o aspecto e as feições dessa gente faminta e sofrida, que vagava tanto nas estradas, quanto nas ruas das cidades, muitos deles sem nada, maltrapilhos e com rostos desfigurados pelas mazelas do abandono e da fome. Chagados pelo sofrimento do corpo e da alma, se sentiam quase bicho devido ao aspecto esquelético e desagradável, bem como ao estereótipo que muitos faziam dessa gente pobre e abandonada. Devido à falta de água para banho e asseio diário, tomando um aspecto de bicho, daí a denominação de "cassaco", espécie de bicho muito comum na caatinga e que exala forte odor desagradável, razão pela qual muitos desses retirantes tiveram essa denominação a eles associada. Termo usado com desprezo para desqualificar os pobres flagelados que acorriam à irmandade e aos seus líderes.

"Mas, o que mais irritava aos crentes era a maneira arrogante - (como refugo humano) - quase animal - como eram tratados os flagelados da grande seca de 1900, na região e ainda eram chamados de 'cassacos', bicho repelente e malcheiroso" ${ }^{36}$. Há outro fenômeno social comum aos períodos de seca, que era uma das alternativas diante do abandono e do banditismo praticado nos sertões, e que em ambas as situações se colocavam como refúgio do fenômeno social muito comum no Nordeste, resultado da convulsão social.

Em geral, irmandades como a da Santa Cruz do Massapê, a Légio Crusís e posteriormente a da Santa Cruz do Deserto, do Beato José Lourenço, fundada no sertão do Cariri, surgem como organizações que congregam membros em suas fileiras, grupos marginalizados e excluídos socialmente, economicamente e tanto politicamente quanto religioso, longe dos padrões e dos modelos de irmandades oficiais existentes na época. Logo, a Irmandade da Cruz não seria diferente de outras, sofrendo o preconceito e a indiferença dos poderes constituídos seja no âmbito civil quanto religioso.

Os cronistas da época, as autoridades policiais e a própria Igreja não admitiam o caráter fanático religioso, messiânico e até influenciado em parte pelo sebastianismo português, ideais albergados num fanatismo ignorante dos líderes dessas irmandades, posto que, visassem o bem dos pobres e a socorrer os famintos das secas de 1877/1880 e 1900, dentre outras ${ }^{37}$.

35 RAMOS, Francisco Régis Lopes, Op. cit., p. 78.

THOMAZ NETO, Op. cit., p. 49. Grifo do autor.

THOMAZ NETO, Op. cit., p. 34. 
Essa política criava uma sofisticada rede de favorecimento de políticos locais e dos administradores e gestores das obras públicas que, corrompidos por uma ganância desmedida, não tinham a devida caridade para com os as famílias famintas dos flagelados. Isso diferenciava da prática da Irmandade da Cruz, e de seu líder Damião junto daqueles pobres abandonados.

Tudo que fazia, tinha por objetivos salvar seus irmanados flagelados, que acorriam em Massapê, suplicando a proteção da Irmandade da Cruz, depois de esgotadas todas as suas esperanças, apresentadas pelos poderes constituídos com as mãos cheias de palavras vazias ${ }^{38}$.

Apesar de todos os benefícios sociais e espirituais, a Irmandade da Cruz foi hostilizada e vista como inimiga da classe dominante, que via com desprezo e arrogância, sendo tratada como tal, o que fez com que se mobilizasse todas as forças para sua eliminação e se apagasse da história qualquer registro de sua existência. É o que atesta Antônio Tomas Neto:

Não se encontraram vestígios, até o presente momento, da atuação dos primeiros edis do novo município, a respeito dessa irmandade. E se foram a favor do massacre, prestaram um desserviço a uma comunidade marcada pelos castigos da grande seca de 1900 - se foram contra, também nada fizeram para impedir tamanha violência - de qualquer maneira deixaram uma nódoa, um luto, e ainda ao que parece de tudo fizeram, para nada ficar registrada, qualquer providência administrativa nos anais do recém-criado município ${ }^{39}$.

Não por menos, o Governo do Estado junto com as elites locais se colocaram com bastante preocupação ao crescimento e propagação da Irmandade da Cruz, não só com relação ao seu discurso de denúncia velada aos desvios de recursos das obras públicas do Açude Acaraú-mirim e aos desmandos dos políticos, bem como do uso político pelos coronéis e seus colaboradores. Assim, igual a outras irmandades e movimentos, elas foram perseguidas, pois era necessário conter mais um perigoso antro de fanáticos, razão pela qual era comum também associar a Irmandade à ideia do risco de fanatismo religioso, ideia tão combatida na época, principalmente depois de Canudos e outros movimentos messiânicos. Logo, somente com a desorganização e extermínio da irmandade e de seus líderes resolveria os problemas causados pela sua existência.

Não interessava ao Estado, nem às elites, a existência de um agrupamento fora do que era tido como normal [...] A lem- 
brança de Canudos estava relacionada à ideia de prevenção que as autoridades tinham no sentido de evitar um caso considerado similar ${ }^{40}$.

Portanto, não havendo justificativa mais provável senão essas, a Irmandade da Cruz e seus líderes foram perseguidos, sendo extinta com o massacre de 26 de março de 1902, como descreve Guilherme Studart:

Em 26 de março de 1902 - na vila de Massapê, ao sopé da Serra da Meruoca, são presos por uma força de polícia comandada pelo tenente Érico Carapeba, os chefes principais dessa malta de indivíduos conhecidos pelos nomes de Irmandade da Cruz, que fora fundado em princípios de Abril de 1900, pelos célebres cangaceiros: CAMPELLO, VEADO, FURTADO, E FELIPPE. Usavam um chapéu de abas largas tendo ao centro uma cruz preta ${ }^{41}$.

Após esse fato descrito por Studart ${ }^{42}$, não há outra descrição mais precisa sobre o fim da irmandade e de seus líderes, o que se sabe é que Damião e seus outros companheiros foram, a partir de então, jogados no rio do esquecimento e enterrados não só nas águas profundas do açude Acaraú-mirim, mas também sepultados da memória de um povo que teve de esquecer parte de sua história. "O pior destes crimes é que tinha autores, cadáveres como prova material de todos os fatos, [...] foram também enterrados - estes, não na mãe terra - mas ficaram quase insepultos - por assim dizer no local que anos depois ficaram sob as águas do açude Acaraú-mirim" ${ }^{33}$. Tudo isso se deu, para que mais de cem anos depois pudesse emergir como um grito profético de denúncia, clamando pelo direito à memória e poder reinventar e fazer parte da "história de nossa gente".

\section{Fonte oral:}

Raimundo Nonato Costa, neto de Vicente de Pinho; morador da Várzea da Cruz, e que trabalhou no açude Acaraú-mirim e viveu mais de cem anos de idade. Entrevista realizada pelo autor em 26 de setembro de 2018. Massapê-Ceará.

\footnotetext{
RAMOS, Op. cit., p. 124

1 THOMAZ NETO, Op. cit., p. 18.

42 Studart narra em Datas e Fatos sobre a história do Ceará como foi a condução até Fortaleza, e o fim que coube aos líderes da Irmandade da Cruz após o massacre do Massapê.

43 Op. cit., THOMAZ NETO, p. 129.
} 



\section{Parte 2}

\section{O mundo do trabalho e da educação}





\title{
7."Se a gente fosse viver só de trabalhar pros outros a gente morria”. Memórias da Casa Grande: moradores, rendeiros e agregados na cidade de Alcântaras-CE (1907-1920)
}

\author{
Jaiana Kelly Rodrigues Alcântara ${ }^{1}$
}

\section{A cidade de Alcântaras-CE: apontamentos necessários}

O objetivo deste estudo é perceber as memórias que existem em torno dos casarões antigos localizados na cidade de Alcântaras- $\mathrm{CE}^{2}$, entendendo-os como espaços de trabalho de homens e mulheres. Identificamos que no sítio Algodões moravam pessoas de influência política desta cidade no século XX, tornando-se assim, fundamental perceber as relações existentes entre as alianças políticas e o trabalho que existia nas redondezas em torno dos casarões. Para desenvolver este estudo, foi necessário ouvir os relatos e memórias de trabalhadores, que diferiam entre moradores, rendeiros e agregados e que mantinham laços e relações com seus patrões.

Michel de Certeau, em seu livro a Escrita da História, ao nos questionar "O que fabrica o historiador quando 'faz história'? Para quem trabalha? O que produz?" , lança a campo uma série de questionamentos necessários para o fazer historiográfico. Sendo a história um produto, ela não está acabada, muito menos limitada às datas, nomes e homens de renome, sendo necessário ir além da historiografia oficial. O trabalho do pesquisador exige uma lida com um espaço e um tempo especifico, tendo assim a "particularidade do olhar de onde falo e o domínio que realizo uma investigação"4, isso se deve à relação da pesquisa historiográfica com um lugar, ou seja, o texto é produto de um lugar social.

Graduanda do Curso de Licenciatura em História da Universidade Estadual Vale do Acaraú- UVA. Sobral-CE. Bolsista do Programa de Educação Tutorial PET-HISTÓRIA-UVA.

As primeiras notícias do território de Alcântaras, anteriormente denominado Sítio São José, fazem referência ao casal José de Araújo Costa e sua esposa, Brites de Vasconcelos. Somente no ano de 1898 que se teriam referências à construção da primeira casa de tijolo do Sítio São José, que atualmente corresponde ao local onde está situada a Casa Paroquial.

CERTEAU, Michel de. A Escrita da História In: A Operação Historiográfica. Rio de Janeiro: Forense-Universitária, 1982, p. 65.

Idem. 
Será justamente no considerado período republicano, período em que muitas transformações culturais, políticas e sociais ocorriam no Brasil, que teremos notícias das construções dos primeiros casarões da cidade de Alcântaras. Será nesse período também que a cidade terá seu território desmembrado de Meruoca, e consequentemente os moradores da região passaram a se identificar como alcantarenses e a se sentirem como parte integrante daquele território. Notamos no Sitio Algodões, localizado na cidade de Alcântaras, a presença de casarões ${ }^{5}$ com uma arquitetura no estilo neocolonial ${ }^{6}$. Foram essas casas que possibilitaram à realização deste estudo, percebendo estes espaços para além de uma arquitetura detalhada, identificando deste modo as sociabilidades e alianças entre trabalhadores e donos de grandes propriedades de terra.

Observa-se que na sede da cidade de Alcântaras são escassas ou quase inexistentes casas que conservem suas características originais, com uma arquitetura detalhada do século XX. Uma das poucas que ainda mantêm alguns traços originais é a casa que pertenceu ao primeiro prefeito da cidade, Roberto Ximenes Aragão ${ }^{7}$, localizada em frente à praça João Capistrano ${ }^{8}$ (Praça da Igreja Matriz). No entanto, a mesma já passou por várias reformas que alteraram sua estrutura. A partir dessas análises, surgem questionamentos sobre a ausência de casas antigas no considerado "centro" da cidade de Alcântaras, que se tornou centro porque foi onde se instalou a família de João Capistrano e foi onde ele ergueu a capela em homenagem a Nossa Senhora do Perpétuo Socorro, capela esta que deu origem ao espaço da atual Igreja Matriz.

Estas informações nos possibilitam adentramos na ideia da suposta "modernização" ou "progresso" da cidade, que nos ajuda a pensar sobre o modo como estão sendo tratadas essas edificações arquitetônicas antigas que se constituem como parte do patrimônio histórico da cidade. Cabe a nós historiadores fazermos destes espaços objetos de estudo que nos permitam entender nosso passado e problematizá-lo.

O estudo desses casarões pode nos falar da situação econômica, política e social do Brasil e do Ceará em determinado período. Desconstruindo este espaço, percebemos que "a casa é muito mais que um emaranhado de barro, taipa, telhas, palhas e madeiras, e deve também ser compreendida a partir dos seus significados sociais" ${ }^{\prime \prime}$. Elas podem falar sobre a condição dos mora-

\footnotetext{
O casarão mais antigo que conseguimos encontrar data do ano de 1907 e era pertencente a Domiciano Gomes, grande proprietário de terras da região.

6 Esse estilo resgatou a arquitetura e motivos decorativos típicos da época colonial e empregou-os na arquitetura contemporânea. As principais características da Arquitetura Neocolonial podem ser observadas, por exemplo, no uso de azulejos, treliças, os beirais, as varandas e os pátios ensolarados. Esteve no poder do ano de 1959 a 1962.

Considerado pelos memorialistas o fundador da cidade de Alcântaras.

9 LEMOS, Carlos. História da Casa Brasileira. São Paulo, Ed. Contexto, 1989, p. 87.
} 
dores, sobre os espaços de sociabilidade, sobre a ideia de morada; a própria estrutura dos quartos pode dizer sobre a relação afetiva existente na época. A presença de muitos armadores ${ }^{10}$ pode revelar se as pessoas dormiam muito em rede ou se preferiam camas, a mobília pode informar sobre as condições sociais da família e suas posses.

Como mencionado, o Sítio Algodões, atualmente pertence à cidade de Alcântaras, no entanto, durante muito tempo o atual núcleo urbano da cidade, era denominado de Sítio São José, e ambos os sítios pertenciam à cidade de Meruoca. Através das leituras e estudos feitos sobre os primeiros moradores do referido sítio, identificamos que a família Albuquerque habitava o Sítio Algodões. Segundo o historiador Francisco Sadoc de Araújo: “João Bento de Albuquerque residia no Sítio Algodões, na Serra da Meruoca [...] era chefe político do Partido Liberal." ${ }^{11}$ Segundo Vasconcelos "a família Albuquerque é a grande povoadora do Sítio Algodões" ${ }^{12}$, essa família estabeleceu relações de variadas formas, os casamentos das filhas de João Bento de Albuquerque eram realizados com tenentes, doutores, generais, que tinham suas raízes no sítio Algodões, mas que iam embora para outros estados e outras cidades ${ }^{13}$.

Ainda abordando a relação das posses de terras dos Albuquerques na Serra da Meruoca, identificamos que Gabriel Ponciano de Albuquerque era um dos grandes proprietários de sítios de plantar lavoura na referida serra. Ao analisarmos o estudo de remanejamento do Ceará ${ }^{14}$, foi possível perceber que Ponciano agregava muitos moradores e rendeiros que viviam e produziam em suas terras, desse modo, vemos o quanto a terra era um bem precioso e sinônimo de riqueza. No entanto, não se bastava ter terras, era necessário ter trabalhadores que as tornassem produtivas, era preciso expandir territórios e desenvolver atividades de acordo com as possibilidades do ambiente.

Como nos afirma Lilia Schwarcz e Heloísa M. Starling, para realizar a pesquisa histórica é preciso "penetrar num tempo que não é nosso [...] sentir com os sentimentos de outras pessoas [...]"15. Estudar a relação de sujeitos históricos com seus espaços requer "reconhecer o caráter inconcluso da história", dessa forma, para reconhecer essa inconclusão que permeia a narrativa histórica, adentraremos nas memórias dos variados sujeitos.

10 Peças de ferro encravados nas paredes das casas usadas para armar redes de dormir de uma extremidade a outra.

11 ARAÚJO, F. Sadoc de. Cronologia Sobralense. Volume III. 2a Ed. Edições ECOA, 2015, p.137.

12 DIOGO, Bertoni Vasconcelos. Alcântaras III Séculos de História. Edição do autor. 2016, p.73.

13 Cf: Idem.

14 FROTA, Luciara S. de Aragão (Org.). Estudo do Remanejamento da Pecuária na Zona Norte do Estado do Ceará. Fortaleza: SUDEC, 1974.

15 SCHWARCZ, Lilia Moritz, STARLING Heloísa Murgel. Brasil: uma biografia. $1^{\circ}$ ed. São Paulo. Companhia das Letras, 2015, p. 20. 


\title{
"Se a gente fosse viver só de trabalhar pros outros a gente morria": o trabalho e a memória
}

A memória é importante para a compreensão de uma possível relação identitária. Sabendo das diversas estratégias que existem para lembrar ou esquecer, é necessário destacar a necessidade de abordar os registros das lembranças. No entanto, devemos nos ater na observação de que a história oral não é um instrumento de mudança da realidade, e sim uma forma de explicá-la, como ela foi moldada e os fatos que contribuíram para sua formação. Não obstante, se relacionarmos com a própria história, veremos que a história oral pode ser um meio de transformar seu conteúdo e sua própria finalidade.

\begin{abstract}
A história oral [...] pode ser utilizada para alternar o enfoque da própria história e revelar novos campos de investigação, pode derrubar barreiras que existiam entre gerações entre instituições educadoras e o mundo exterior e na produção história $^{16}$.
\end{abstract}

A história oral neste estudo ajuda-nos a perceber a memória do trabalho das pessoas que atualmente ainda residem no Sítio Algodões. Faz-se neces88| sário que discutamos o sentido deste trabalho e a que ideia está associado. Ao estudarmos esses casarões como espaços de sociabilidades e de trabalho, falamos daquelas pessoas que trabalhavam pela sobrevivência, como os próprios entrevistados mencionavam: "trabalhava por um prato de comida".

Retomando questões já apresentadas, as inquietações estavam relacionadas aos três casarões principais existentes no Sítio Algodões. Esses casarões mostram uma estrutura forte, os donos já morreram e eles ficaram nas mãos de "moradores". O casarão que pertenceu a José Pompílio Aragão, conhecido como Zuza, atualmente é cuidado pela nora do falecido, enquanto o casarão que era de propriedade de Zeca Tomás hoje é a casa de morada de um casal que não tem nenhuma relação familiar com os primeiros donos, e o casarão que pertenceu ao falecido Domiciano Gomes atualmente está sendo cuidado pela família do falecido.

Dentro desses espaços é possível perceber a presença de móveis de madeira, que apesar do tempo continuam em um ótimo estado. A presença de quadros de santos também é marcante, evidenciando o catolicismo dos moradores e dos primeiros proprietários; em todos os quartos havia camas, e o quarto do casal das três casas observadas eram os mais luxuosos. Nestes casarões, as calçadas eram bem altas feitas de pedras, onde podemos observar

16 BOSI, Ecléa. Memória e sociedade: Lembranças de velhos. $6^{\mathrm{a}}$ Edição, São Paulo: Companhia das Letras, 1998, p. 20. 
um distanciamento do chão, o que permitia à casa uma altura privilegiada em comparação com as demais.

Os questionamentos principais que propiciaram chegar ao estudo dos casarões no Sítio Algodões foram: quem construiu essas casas naquele período? As pessoas que trabalhavam na construção ganhavam o que em troca? Os donos das casas, os donos das terras fariam o trabalho braçal? Segundo um dos entrevistados, "essas casas antigas só foi levantada à custa dos escravos, botava eles pra trabalhar. O dono da casa não tinha condições de levantar uma casa dessa daqui, tudo foi às custas dos escravos ${ }^{17}$.

A palavra escravo, acima mencionada na fala de Raimundo Xavier, remete à ideia de um trabalho pesado, com pouco ganho. Quando questionado sobre o trabalho, a venda e compra de terras e sobre como funcionou esta questão no Sítio Algodões, Seu Raimundo respondeu:

Trabalhavam por um milheiro de feijão, como esse pessoal mais pobre que tinha era dono dessas terras, esse pessoal que tinha mais poder, esses pobres não tinha nada e então vendiam a terra por um litro de feijão, um litro de farinha. Aqui tinha uma mulher, era a Luzanira, e tinha um véim lá do Benedito que tinha terra, ela comprou as terras dele todas nessa arrumação, por um litro de farinha, um litro de feijão ${ }^{18}$.

A partir dessa fala podemos perceber as relações estabelecidas nas vendas de terras. As pessoas mais pobres que haviam pioneiramente ocupado o espaço e tinham uma forma própria de lidar com aquela terra, muito possivelmente de subsistência, negociavam as terras com as pessoas que tinham mais posses. No entanto, os mais ricos sentiam a necessidade de expandir suas posses, para ter mais produção, ou seja, a terra acabava sendo negociada pelas pessoas mais pobres de acordo com suas necessidades. $\mathrm{O}$ entrevistado, Raimundo Xavier, trabalhou para José Pompílio Aragão ${ }^{19}$, conhecido como "Seu Zuza", que era um grande senhor de terras, tinha muitos trabalhadores e moradores, tendo sido proprietário de um dos casarões citados neste estudo. $\mathrm{Na}$ entrevista, relata:

Eu também trabalhei, trabalhei pro Zuza ali, eu trabalhei na base de 8 anos, não ganhava nada não, minha família trabalhava pra eles. O pai, a mãe trabalhava na cozinha deles. Tinha muito gado nesse tempo. Trabalhava demais. Quando nós chegava em casa pra almoçar, a hora mais cedo que tinha

17 Raimundo Xavier Braga, 65 anos, agricultor, morador no casarão do falecido Zeca Tomás. Entrevista realizada pela autora em 16/09/2017 na residência do entrevistado.

18 Idem.

19 Foi candidato a prefeito na primeira eleição do município de Alcãntaras. 
era 10 horas da noite, a hora mais cedo, às vezes era 1 hora da manhã. Era de manhã. Sem tomar água, às vezes nem café num tinha. Do jeito que amanhecia o dia nós ia. Minha vida era trabalhar de graça pra eles. Estudar eu não tinha direito de estudar. Eu nunca fui na minha vida numa escola, a coisa que eu tinha mais vontade, tinha não, tenho, era aprender ler, fazer pelo menos meu nome que eu não sei. Quando falava com o véi, ele mesmo não deixava. As minhas irmãs, elas não sabem de nada porque elas não queriam, elas não se interessavam. Agora eu era porque eles não deixavam eu ir, pra trabalhar, pra trabalhar pra eles, eu queria ter aprendido alguma coisa na vida. Eu não tinha vontade de enricar, eu não tinha vontade de me casar, eu queria estudar. A gente não pode ter inveja dos outros, mas disso daí eu tem ${ }^{20}$.

A partir da fala do entrevistado, podemos analisar o tempo de trabalho e as condições às quais estavam submetidos os trabalhadores da região de Alcântaras no período em estudo. Percebemos que o trabalhador não fazia outra coisa além de trabalhar e o que ganhava era o básico para a sobrevivência. O entrevistado fala ainda sobre o desejo que tinha de estudar, e o patrão não deixava, segundo ele era mais fácil as mulheres aprenderem a ler do que os homens, uma vez que o trabalho delas era mais leve. Desse modo, identificamos uma diferença do trabalho destinado aos homens e às mulheres.

As mulheres no Sítio Algodões trabalhavam principalmente nas casas de famílias, exercendo atividades diferentes da dos homens. A entrevistada afirma que:

Não tinha Prefeitura, a Prefeitura era só para os ricos, não dava vez ao pobre arrumar um meio de vida não. Eu acho que eu ainda cheguei a esse tempo dos escravos, trabalhei, trabalhei 9 anos na casa dos ricos, nunca arrumei nada, eu sou desse tempo ${ }^{21}$.

A entrevistada reconhece o trabalho desempenhado na sua adolescência como "ser escravo", que mesmo não estando nas piores condições, nem sofrendo maus tratos físicos, a pobreza reinava e o único meio era trabalhar para as pessoas de mais posses, para os "donos de terras". Muitos dos trabalhadores viviam ainda na condição de "alugado", que era aquele que morava na terra e tinha que torná-la produtiva. Demostrando as estratégias usadas para a sobrevivência, a entrevistada afirma: "se a gente fosse viver só do alugado, a gente passava fome. Todos os anos meu marido fazia roçado. Se a gente fosse viver só de trabalhar pros outros a gente morria"22.

\footnotetext{
Raimundo Xavier. Entrevista já citada.

21 Katia Nunes da Silva, 58 anos, esposa de Raimundo Xavier Braga, moradores do casarão do falecido Zeca Tomás. Entrevista realizada pela autora em 16/09/2017 na residência dos entrevistados.

22 Rita Diniz Ferreira, 77 anos, aposentada. Moradora nas terras do falecido José Pompílio Aragão. Entrevista realizada pela autora em 16/09/2017 na residência da entrevistada.
} 
Trabalhar com a memória é trilhar um caminho de lembranças, imaginação e de vivências. Os pesquisadores necessitam destes sujeitos com suas memórias; não devemos naturalizar a história e as suas mudanças, elas não nascem prontas, passam por um processo, uma metamorfose que se encaixa em um tempo, mas não se limita a ele:

A memória ajuda a refazer e a preservar o lugar, por meio de lembranças afetivas de relações familiares, caseiras e privadas, que se estendem pelas ruas num entreter diário de desencontros, na circulação pelo bairro, nas lojas, nos bares onde os homens se encontram para descansar, conversar e fumar, nos locais de brincadeiras das crianças, nos locais de culto, etc. ${ }^{23}$.

O trabalho realizado por estes trabalhadores agregados e rendeiros em torno das casas grandes e de seus donos eram diversos. Além das casas para a morada, cada casarão possuía uma casa de farinha e um engenho. Como trabalhavam essas pessoas que moravam nestas terras? Que atividades desenvolviam? Quais os interesses destes sujeitos? Seu Raimundo Xavier fala:

Trabalhava nos sítios, nos engenhos. Nesse tempo era só luta com gado, tirando capim botando pra eles. Alimpar cajueiro, tudo era na enxada. Minha vida era tangendo jumento. Minha mãe trabalhava no Zuza e no Domiciano. Quando ela ia, morava um bocado de tempo naquela casa, aí o pessoal naquele tempo qualquer coisinha botava pra fora. Depois corria pra um lugar e ia pedir abrigo em outro. $\mathrm{O}$ trabalho era pela mo$\operatorname{rada}^{24}$.

Nas memórias de Seu Edmar, que trabalhava como alugado:

Eu comecei trabalhar alugado no Bom Jesus, onde hoje é Manoel Carneiro. Trabalhava pro Doca Zuza, que é parente do "Bentos" dos Algodões. Doca Zuza era casado com a Velha Maria, irmã do Zeca Tomás. Já sou véim, já conheci muita gente aqui. $\mathrm{O}$ trabalho da gente pra ganhar essa merrequinha era capinando, tinha gado também, o seu Zuza, que era meu patrão $0^{25}$.

Vemos mais uma vez na fala do entrevistado que o trabalho relacionava-se com a moradia e a sobrevivência. A fome persistia e as situações dos agregados, suas ações e atitudes andavam de acordo com suas necessidades.

23 KHOURY, Yara Aun. Narrativas orais na investigação social. Disponível em: https://revistas.pucsp.br/ index.php/revph/article/viewFile/10731/7963. Acessado em 12/09/2018.

24 Raimundo Xavier Braga. Entrevista já citada.

25 José Edmar, 79 anos, aposentado. Morador nas terras do falecido José Pompílio Aragão entrevista realizada pela autora, em 16/09/2017 na residência do entrevistado. 
Não era simplesmente um trabalho alienante, havia uma lida com um território e interesses envolvidos. Dona Rita Diniz afirma que "botava os pobres pra trabalhar e chamava era os nego [...]. Os Bentos eram os proprietários mais antigos, porque o dono era aquele que fazia uma casa e se apossava do terreno"26.

A memória da comunidade acerca das histórias das casas grandes está sempre relacionada ao trabalho que os moradores, agregados e rendeiros desenvolviam, sendo que "os pobres trabalhavam só pela comida, e a roupinha era assim, estragada" 27 . Como temos demonstrado, o trabalho estava relacionado especificamente às necessidades dos sujeitos históricos envolvidos. Uma das famílias mais influentes do Sítio Algodões, a família Gomes, também tinha sua forma de pagamento aos trabalhadores. Segundo José Ximenes:

Olhe, na Lanchinha um velho me contou, não sou mais menino não, já tô com 84 anos, você olhe que eu não estou mais menino não, o velho contava que trabalhava um dia aqui pros Gomes, pelo um litro de farinha e um litro de feijão, trabalhava pro Domiciano Gomes ${ }^{28}$.

As posses de terras de Domiciano Gomes eram muito extensas, ele tinha muitos agregados e trabalhadores. No interior do casarão, construído no ano de 1907 os móveis são de luxo e estão bem conservados. Um detalhe que chamou bastante nossa atenção foi um oratório bem detalhado dentro do quarto em que dormia o casal, uma casa de farinha muito grande e um engenho. Segundo a filha, as terras do falecido pai eram infindas. Desse modo:

Pensamos que as relações entre as pessoas não se davam apenas em nível de conhecimento parental consanguíneo, mas se ampliava para os moradores de uma localidade ou freguesia, especialmente entre aqueles de sua amizade e clientela ${ }^{29}$.

É importante perceber que as relações e as posses de terras se ampliavam com o passar do tempo, com as mudanças territoriais, com as compras de terras e com o trabalho escravo. Fossem os trabalhadores de Zeca Tomás, José Pompílio Aragão ou Domiciano Gomes, todos estabeleciam alianças e

\footnotetext{
Rita Diniz Ferreira. Entrevista já citada.

27 Raimundo Xavier Braga. Entrevista já citada.

28 José Ximenes, 80 anos, aposentado. Mora no distrito de Carmolândia. Entrevista realizada pela autora em 16/09/2017, na residência do entrevistado.

29 SOUZA, Raimundo Nonato Rodrigues de. "Escravos e sociabilidades." In: "Minha riqueza é fruto do meu trabalho": negros de cabedais no Sertão do Acaraú (1709-1822). Fortaleza: Tese (Doutorado) Universidade Federal do Ceará/ Programa de Pós-Graduação em História Social, 2015, p. 160-200.
} 
relações com seus trabalhadores, através de acordos, de empréstimo de terras e até mesmo de assistência no momento das doenças.

Através da presença de móveis e detalhes nos casarões presentes no Sítio Algodões, na cidade de Alcântaras, é possível identificar que os proprietários tinham condições financeiras favoráveis, pois não seria qualquer pessoa que poderia adquirir móveis luxuosos. Na região em estudo, residiram grandes proprietários de terras, trabalhadores, moradores e rendeiros, que viam no trabalho um meio de vida e uma forma de negociar, de acordo com suas necessidades mais urgentes. Uma informação importante a ser problematizada é que estes proprietários de terras e dos casarões do Sítio Algodões foram dos primeiros a exercer o poder do voto. Segundo o memorialista Juvenal Ferreira de Souza:

Ao findar-se o período de submissão à Meruoca, o aldeamento São José, pertenceu 14 anos a Sobral (1920 a 1934) tempo que alguns são-joseenses começaram a votar. Os primeiros eleitores, que iam, a cavalo, votar em Sobral, foram os cidadãos: Doca Zuza, José Tomaz, João Zuza, Antônio Guilherme de Alcântara e deste, o irmão Guilherme dos Reis de Alcântara Neto. Vale salientar, que durante todos esses anos, Sobral nada fizera pelo povo e o Sítio São José, porém, o mal não fizera ${ }^{30}$.

E são justamente estes nomes que prevalecem nas memórias dos moradores do Sítio Algodões: Doca Zuza, Zeca Tomás, Seu Pompílio (Zuza), Domiciano e Bento, Albuquerque. Percebemos também que o poder e o direito ao voto não se estendia aos trabalhadores, que já vivendo em um período em que se buscava a democracia, não usufruíam dela, isso demonstra que ela não chegou do mesmo modo em todos os espaços e para todos os sujeitos.

É importante também se levar em consideração as próprias estratégias que esses trabalhadores desenvolviam com o seu trabalho e com a fidelidade mantida a seu patrão, bem como os interesses do patrão em manter estes trabalhadores em suas terras e trabalhos. Na fala dos entrevistados, é comum falarem "Padrinho Zuza", "Madrinha Julieta", assim como perceber na fala um sentimento de gratidão aos seus patrões.

Vemos que por mais que as condições de trabalho fossem adversas e o ganho fosse pouco, esses trabalhadores procuravam agir de acordo com seus interesses e o fato de serem moradores, agregados ou rendeiros, não os colocavam sempre em uma situação inferior que a dos donos de grandes propriedades. Havia, portanto, uma relação de troca.

30 Juvenal Ferreira de Sousa - Livro sobre Alcântaras ainda não publicado. 
Nossa Gente,

Nossa História

o Ceará Republicano

\section{Fontes orais}

Raimundo Xavier Braga, 65 anos, agricultor, morador no casarão do falecido Zeca Tomás. Entrevista realizada em 16/09/2017.

Kátia Nunes da Silva, 58 anos, esposa de Raimundo Xavier Braga, moradores do casarão do falecido Zeca Tomás, entrevista realizada em 16/09/2017.

Rita Diniz Ferreira, 77 anos, aposentada. Moradora nas terras do falecido José Pompílio Aragão entrevista realizada em 16/09/2017.

José Edmar, 79 anos, aposentado. Morador nas terras do falecido José Pompílio Aragão entrevista realizada em 16/09/2017.

José Ximenes, 80 anos, aposentado. Mora no distrito de Carmolândia. Entrevista realizada em 16/09/2017.

\section{Fonte escrita}

Juvenal Ferreira de Sousa - Livro sobre Alcântaras ainda não publicado. 


\title{
8. "Depois foi que veio essa modernização": as transformações nos engenhos de cachaça artesanal em Alcântaras-CE (1960- 2000)
}

\author{
Adelina Lopes Guimarães ${ }^{1}$
}

\section{Como tudo começou...}

A história dos engenhos é tão antiga quanto a história do Brasil; a princípio, surgiram os engenhos açucareiros como uma consequência da grande produção de açúcar na Europa, que desencadeou a falta de território propício para a matéria prima desta produção, a cana de açúcar.

A recém-nascida colônia de Portugal, o Brasil, foi a grande receptora dessa planta; seu solo era adequado para a produção e, portanto, fez morada na parte litorânea, principalmente no que depois veio se chamar de Nordeste, mesmo que outrora essa colonização não representasse tanta urgência ou importância.

As primeiras mudas dessa "planta perene da família das gramíneas, originária da costa da Índia, [...] introduzida entre nós desde a chegada dos europeus" e "[...] considerada uma das 'excelências do Brasil' [...]"2, foram trazidas por Martim Affonso de Souza em 1532, iniciando seu cultivo na Capitania de São Vicente, levando a construção do primeiro engenho em terras brasileiras, chamado de Governador e depois São Jorge dos Erasmos.

Depois do plantio e adaptação dessa planta, ela efetivou-se no Nordeste, sendo especificamente nas capitanias de Pernambuco e Bahia que os engenhos açucareiros se multiplicaram e conseguiram gerar grande produção, pois todos os ventos sopravam a favor dessas primeiras indústrias que o Brasil conhecera.

Após esse momento, os engenhos passaram a representar uma atividade que dependia de muitos trabalhadores, para plantar, limpar, colher, transportar a cana até os engenhos, moer, acondicionar e levar até o mar. Esse trabalho era executado por escravos. Trabalhavam exaustivamente durante todo o dia não sobrando tempo para mais nada, a não ser a produção de açúcar, e para além do trabalho no engenho, se dedicavam a outras ativida-

Graduanda em Licenciatura em História pela Universidade Estadual Vale do Acaraú - UVA. E-mail: adelina.lopezz@gmail.com

PRIORE, Mary Del. Histórias da gente brasileira: volume I. São Paulo: Le Ya, 2016, p. 65. 
des extras, como a lavoura, também a mando do senhor de engenho. Eram verdadeiras máquinas humanas, comandadas por um ser superior, o Senhor de Engenho, figura essa "[...] a que muitos aspiram, porque traz consigo, o ser servido, obedecido e respeitado de muitos"3. Existia ainda aquele que era o braço direito do senhor de engenho, responsável por supervisionar todo o trabalho, recebendo o nome de feitor.

Percebemos então que se formara uma verdadeira hierarquia dentro desses ambientes. Não só entre os indivíduos, mas também o local onde cada um residia. Os escravos ficavam nas senzalas, já os senhores de engenhos moravam na Casa Grande.

Para além desses dois edifícios, também existia a fábrica e a capela, todo esse conjunto formava o engenho, podendo haver diferenciações sobre o que seria o engenho, como por exemplo,

[...] no nordeste do Brasil, a palavra engenho é usada para identificar todo o conjunto agrícola, inclusive a plantação, enquanto que em outras regiões a palavra é usada apenas para designar a fábrica (a edificação onde acontece a fabricação do açúcar ou rapadura $)^{4}$.

\section{$\mathrm{O}$ advento das transformações nos engenhos de açúcar}

Todo o trabalho no engenho exigia dos trabalhadores muita força, o cotidiano nesses ambientes era marcado por exaustão, homens e mulheres deveriam se manter em constante atividade, as mulheres levavam as canas e as moíam, os homens também faziam esse e outros trabalhos, como por exemplo, na lavoura, no armazenamento e transporte do açúcar etc.

Mas, para que tudo isso acontecesse, além da força humana outras forças eram utilizadas, como, por exemplo, a força animal e das águas, para mover as moendas que processavam a cana a fim de extrair o caldo indispensável para a produção do açúcar. Uma transformação, portanto, surge, tendo em vista o funcionamento com mais rapidez, gerando mais produção. A força humana passa a ser substituída pela força das águas e dos animais e os engenhos dão mais um passo em suas transformações.

Partindo para o período republicano no Nordeste, percebe-se que medidas importantes foram adotadas nesses ambientes fundamentais para a

SANDRE, Sandra. Cachaça Patrimônio Brasileiro. 2004. 162F. Monografia (especialização em Gastronomia) - Curso de Gastronomia, Universidade de Brasília, Centro de Excelência em Turismo, Brasília, 2004, p. 03.

4 ANDRADE (2008, p. 6-7) Apud FERREIRA; MOURA FILHA, 2012, p. 2). Proteção do patrimônio rural no Brasil: Os engenhos de cachaça e rapadura de Areia/PB. Disponível em: http://www.lppm.com. br/sites/default/files/livros/artigo_II\%20col\%C3\%B3quio_paisagem\%20cultural2.pdf Acesso em: 17 jul. 2018. 
economia brasileira. Anteriormente, os engenhos não tinham um padrão para suas construções, e somente no século XIX, por meio de um plano geral criado por Vauthier, "todos os edifícios se distribuem pelo terreno de modo a limitar, de forma descontínua, um pátio interno retangular"s.

Posteriormente, seria a vez das construções que compunham esses engenhos sofrerem algumas alterações, principalmente a casa do senhor de engenho, referente à sua disposição em relação à capela e à fábrica, formando um edifício sucessivo, "de um lado a casa-grande, no meio à capela, estas em um mesmo nível de piso, e do outro lado a fábrica, em um patamar mais baixo"6.

Mais tarde, com a concorrência do açúcar produzido na América Central pelos holandeses e do açúcar de beterraba na Europa, algo deveria ser feito para reverter a situação, como a mudança das técnicas rudimentares de produção. É então que passam a ser implantados os engenhos centrais, que segundo Pires e Gomes (1994) eram caracterizados por verdadeiros mecanismos industriais. Entretanto, muitos senhores de engenho não conseguiram adaptar-se a esse sistema e passaram apenas a fornecer a cana de açúcar, outros fecharam seus engenhos.

Logo depois, os engenhos passam por mais uma transformação, agora eles iriam passar de engenhos centrais para usinas, onde dessa forma os subprodutos dessa produção como o melaço, rapadura e a cachaça passariam a ser produzidos de forma independente, mas conservando a forma rustica de fabricação.

\section{Modernização dos engenhos de cachaça em Alcântaras}

Cidadezinha pequena localizada no norte do estado do Ceará, cercada pelo verde das plantas dos serrotes, como a jurema, camunzé, jatobá, barriguda, cajueiros, pau-d'arco, capim-gordura, umburana... durante o período chuvoso, dando espaço aos tons amarelados da mudança de estação proporcionados pelo sol do verão que percorre toda a extensão da serra onde está localizada.

Formada por pessoas simples, em sua maioria originária do campo, que sobreviviam daquilo que produziam com as próprias mãos, em suas casas de taipa viviam sem reclamar da vida que o destino reservou, sem luz, nem água encanada, muito menos tecnologia, desfrutavam do que havia de mais belo e sem cobranças, o íntimo contato com a natureza.

Aos poucos iam se estabelecendo mais famílias nesse lugarejo, cada vez mais se viam as chaminés dos fogões à lenha remodelarem o céu com as

PIRES, Fernando Tasso Fragoso; GOMES, Geraldo. A arquitetura dos engenhos. In: Antigos engenhos de açúcar no Brasil. 2. ed. Rio de Janeiro: Nova Fronteira, 1994, p. 34.

6 Idem. 
nuvens de sua fumaça, e o espetáculo do crescimento da cidade se fazia constante, logo logo ela se transformaria de forma lenta, mas com muita beleza. Esse era basicamente o cenário da cidade de Alcântaras ao começar sua ocupação, e com a chegada de novas famílias, aos poucos ela crescia, acarretando nas transformações e consequentemente a modernização.

A modernização aliada ao progresso percorre o Ceará chegando em tempos variados em cada região do estado, ou seja, não aconteceram do mesmo modo nem no mesmo período. Sendo que "o advento da república foi propagado como a reordenação político-institucional capaz de redimir o Brasil do atraso em que esteve submerso pelo "provincianismo" [...]"7.

$\mathrm{Na}$ cidade de Alcântaras, a chegada dessa modernidade será analisada através das transformações ocorridas nos ambientes de trabalho, especificamente nos engenhos de fabricação de cachaça Serrana. Com seus caules resistentes, apresentando diversos nós, com folhas compridas, largas e sedosas, suas flores pequenas formando um pendão, tornam a paisagem ainda mais bonita com o contraste entre o verde das folhas e o rosado das flores. Será essa planta a responsável por uma transformação na paisagem da cidade, como bem conta Diogo (2016):

Outra mudança significativa aconteceu às margens onde corre as águas do riacho Pau Ferrado, sendo derrubada a vegetação nativa, conservando apenas algumas touceiras de bananeiras, e plantando os primeiros talos da cana. $[. . .]^{8}$.

Por meio do fragmento acima, também se constata que através da presença da cana outro estabelecimento surge, os engenhos, responsáveis por produzirem rapadura e cachaça, gerando assim renda para aqueles que passavam dias na labuta dessa fabricação que não se restringiam somente no produzir a famosa cachaça serrana ou a rapadura.

Esses engenhos foram passados de geração em geração, como bem relata Sr. Mauriene, ao falar sobre origem do engenho situado próximo ao riacho do Pau Ferrado, expondo que "é porque era tradição. Desde o pai dele que tinha o engenho, né, aí ele continuou [...]" . A princípio era movimentado à tração animal, bem como os outros engenhos na cidade e dos sítios pertencentes ao município.

Como esses engenhos chegaram ao município, não se sabe, pois não apresentavam nenhuma documentação referente à construção e funciona-

SOUZA, Simone de. Uma nova História do Ceará. 4. Ed. Fortaleza: Edições Demócrito Rocha, 2007, p. 179.

8 DIOGO, Bertoni Vasconcelos. Alcântaras III Séculos de História. 1. Ed. Alcântaras- CE: Edição do Autor, 2016, p. 257.

9 Francisco Mauriene Alcântara, 67 anos, agricultor aposentado e antigo trabalhador de engenho. Entrevista realizada pela autora em 04 de agosto de 2018. Alcantâras-CE. 
mento desses espaços de fabricação de cachaça, assim como as casas de farinha, que também sofreram transformações ao longo do tempo, havendo a ausência de documentação.

Por meio dos relatos de experiência utilizados como fonte para essa produção e do esquecimento que está sujeito a acontecer, como diz Verena Alberti, "a história, como toda atividade do pensamento humano, opera por descontinuidades: selecionamos acontecimentos, conjunturas e modos de viver, para conhecer e explicar o que se passou"10, portanto, afirmar quando e quem os introduziu pela primeira vez torna-se quase improvável.

Todavia, será através da oralidade, ou seja, através do "uso da voz humana, viva, pessoal, peculiar, faz o passado surgir no presente de maneira extraordinariamente imediata" ${ }^{11}$ que as transformações ocorridas nessas primeiras fábricas serão rememoradas.

Segundo outro trabalhador e dono de engenho, ao relembrar sobre a forma de movimentação do engenho de sua família relata que "esse engenho era puxado a boi. Passou-se muitos anos sendo puxado a boi, né, como também tinha nos outros vizinhos que tinha. O seu Virgílio que era bem na frente [...]". No decorrer do seu relato, o narrador aponta o sofrimento que eram os engenhos puxados a boi: "Antigamente era muito sacrificoso besta, tinha que colocar boi, você tinha que amansar o boi, o boi ninguém comprava não, era da criação da gente [...]" ${ }^{12}$.

Vale ressaltar que no período de criação desses engenhos ainda não existia energia elétrica em Alcântaras e, por isso, a utilização de animais para moverem o engenho. Outros já podiam desfrutar dessa novidade, mas as condições de modificar a fábrica muitas vezes não os permitiam tal serviço. À medida que a cidade crescia, as transformações modificavam o cenário daquele lugarejo de uma beleza natural, como por exemplo, quando as árvores secas e sem folhas no período do verão pareciam estar mortas, ao serem tocados com apenas algumas gotas d'água das chuvas que anunciavam o inverno, são capazes de transformar aquilo que parecia estar morto em vida.

O trabalho iria muito além do que colocar a cana depois de limpa na moenda, a fim de a esmagarem e extraírem um caldo de cor esverdeada e doce e depois destinar tal produto para a fase seguinte $\mathrm{O}$ trabalhador "fazia de tudo, desde o plantio de cana, tudo, até chegar à cachaça. Olha, eu plantava cana, capinava, eu levava gado pro sertão, eu ia buscar, e no verão nós na cachaça aqui direto e lutando com gado e fazendo cachaça"13.

10 ALBERT, Verena. Ouvir contar: Textos em História Oral. Rio de janeiro: Editora FVG, 2004, p. 13.

11 THOMPSON, Paul. A voz do passado: História Oral. 2a Edição. Rio de janeiro: Editora Paz e Terra, 1992, p. 41.

12 Raimundo Waldemar Ximenes (conhecido também como Mazim), 78 anos, funcionário público aposentado e antigo trabalhador de engenho. Entrevista realizada pela autora em dia 18 de julho de 2018. Alcântaras-CE.

13 Francisco Mauriene Alcântara. Entrevista já citada. 
Outra significativa transformação estava relacionada ao maquinário dos engenhos; os mais recentes são de ferro, mas, em tempos anteriores, eram de outro material, como evidencia o Sr. Mauriene: "de primeiro tinha era a madeira, engenho de madeira, ali na finada Dora tinha um que essas peças eram feitas de madeira, esse era que era antigo mesmo que as moendas eram de pau"14.

Outra modificação estava relacionada à disposição desse maquinário, voltando novamente para os engenhos mais recentes, suas moendas de ferro são dispostas na horizontal, já os que já eram de ferro podiam ser dispostos de outra forma. Ainda utilizando a fala do Sr. Mauriene "antigo mesmo, antigo mesmo era aquele dali que as moendas eram em pé [...]"15.

Com o passar do tempo, a construção de novas casas, a capela, o mercado, os engenhos mudavam o cenário da cidade, trazendo vida onde outrora mais parecia um deserto. Mas essas transformações não cessavam e, "no ano de 1947 as ruas de Alcântaras são iluminadas com energia elétrica, tendo o auxílio de um gerador" ${ }^{16}$. Essa novidade não iria trazer um ar novo somente para a cidade em si, mas também para os engenhos.

Os engenhos, como visto anteriormente, eram movidos por bois, a produção era bem limitada devido essa energia utilizada, e com a presença da energia elétrica seria possível melhorar a produção que teria melhores condições para fabricar a cachaça, além de aliviar o sofrimento daqueles que trabalhavam nestes engenhos.

Ainda sobre este fato, na fala dos trabalhadores entrevistados percebe-se essa transição da força usada para mover os engenhos, onde a modernidade faz parte de seus discursos, como veremos na fala do Sr. Mazim ao relatar sobre como era movido o engenho de sua família.

\begin{abstract}
O engenho era logo ali do lado da casa de farinha, os bois ficavam rodando, porque a produção do caldo de cana era bem devagarzinho puxada a boi, tanto o do papai como o do seu Virgílio, como do seu Gregório, depois foi que veio essa modernização [...].

Os engenhos eram movidos a bois, depois foi motorizado, meu era a óleo diesel e dos outros eramelétricos $[\ldots]^{17}$.
\end{abstract}

A presença da energia elétrica em âmbito nacional estava associada às questões de modificação e modernização das cidades, bem característico do período republicano, assim, "transportes, eletrificação e indústrias químicas

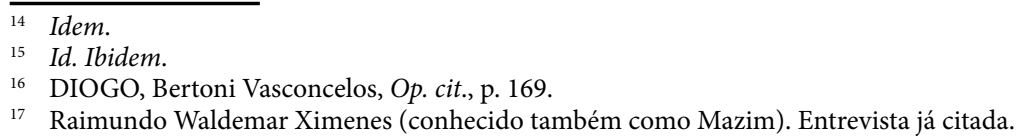

17 Raimundo Waldemar Ximenes (conhecido também como Mazim). Entrevista já citada. 
transformavam a sociedade"18. Portanto, a modernidade surge com o advento da eletricidade, trazendo elementos de modernização, como a presença de novas tecnologias nos engenhos da cidade de Alcântaras.

Com a chegada da energia os engenhos produziam uma grande quantidade de cachaça, como relatam os trabalhadores, além de ser um bom investimento para se obter dinheiro. Por meio da fala de um dos entrevistados, o Sr. Francisco Ximenes, podemos perceber o que fora dito anteriormente, quando ele narra que "é muito bom uma fábrica pra se apurar dinheiro, era muito bom, tinha dia que eu fazia mais de 200 litros de cachaça"19.

Parcialmente, essa modernidade que deu vida nova aos engenhos foi a mesma que causou sua decadência, com a produção da cachaça industrializada ligada a grandes marcas comerciais, além dos períodos de seca característicos da região. Com estes fatores, a cachaça Serrana, de fabricação artesanal, deixou de ser produzida e vendida em grande quantidade no comércio interno, pois todo seu processo de produção, por contar com técnicas rústicas, acarretava no encarecimento da bebida.

Apesar do contexto de escassez na produção da cachaça Serrana, isso não foi capaz de retirar desta bebida seu prestigio em relação à qualidade, pois ela, culturalmente, adquiriu uma identidade, mesmo que não ultrapassasse os limites do município, como acontece com as grandes indústrias que atingem outras regiões com seus produtos.

Fazendo uso da oralidade e das experiências de antigos trabalhadores dessa cidade, que durante as entrevistas iam tecendo os fios da memória e relembrando momentos importantes naqueles ambientes, percebemos o quanto os espaços dos engenhos, mesmo apresentando técnicas rústicas se modernizaram, como podemos exemplificar, nas grandes empresas produtoras de cachaça. Apesar dos engenhos artesanais da cidade de Alcântaras não se encontrarem em funcionamento, as memórias de momentos vividos nestes espaços do trabalho permanecem vivas nas lembranças desses trabalhadores e da população, que vivenciaram esta experiência.

\section{Fontes orais}

Raimundo Waldemar Ximenes (conhecido também como Mazim), 78 anos, funcionário público aposentado, e antigo trabalhador de engenho. Entrevista realizada pela autora em dia 18 de julho de 2018, em sua residência na cidade de Alcântaras-CE.

PRIORE, Mary Del, Op. cit., p. 219.

19 Francisco Ximenes Guimarães, 82 anos, agricultor aposentado, e antigo trabalhador de engenho. Entrevista realizada pela autora em 29 de maio de 2017. Alcântaras-CE. 
Nossa Gente,

Nossa História

o Ceará Republicano

Francisco Ximenes Guimarães, 82 anos, agricultor aposentado, e antigo trabalhador de engenho. Entrevista realizada pela autora em 29 de maio de 2017, em sua residência no Sítio Bom-Fim pertencente ao município de Alcântaras-CE.

Francisco Mauriene Alcântara, 67 anos, agricultor aposentado e antigo trabalhador de engenho. Entrevista realizada pela autora em 04 de agosto de 2018, no engenho pertencente ao Sr. Quinca Gregório na cidade de Alcantâras-CE. 


\title{
9. Sindicato dos Trabalhadores Rurais de Coreaú-CE: criação e processo de organização (1965-1990)
}

\author{
Sebastião Ferreira Carneiro ${ }^{1}$
}

\section{Introdução}

A preocupação central deste trabalho é compreender como se deu o processo de formação sindical no Brasil, notadamente em Coreaú, em 1965, deu-se início, no sentido de se entender questões da formação e do movimento sindical no período da ditadura militar, processos estes que se desencadearam em todo o país. No Ceará, tivemos a criação da FETRAECE (Federação dos Trabalhadores Rurais Agricultores e Agricultoras Familiares do Estado do Ceará), que representa os sindicatos rurais no Ceará. Em Coreaú-CE, a criação do Sindicato dos Trabalhadores Rurais - movimento este que teve a participação da Igreja Católica, teve um papel importante nessa organização para representar esta classe juntamente com outras associações sindicais nos movimentos na esfera estadual e federal, na busca por direitos e melhores condições de vida.

Neste estudo, portanto, é analisada a organização dos trabalhadores rurais no município de Coreaú ${ }^{2}$, tendo em vista o papel exercido pela Igreja, qual sua contribuição na criação do sindicato dos trabalhadores rurais. Para tanto, é feita uma análise sobre os problemas da exploração e a falta de acesso à terra, além do processo de organização dos trabalhadores rurais. Para desenvolver essa análise, foram utilizados relatos de pessoas que vivenciaram esses momentos na prática. Para compreendermos melhor essa organização, nos fundamentaremos na historiografia específica do tema.

Graduando do Curso de Licenciatura em História da Universidade Estadual Vale do Acaraú - UVA.

O município de Coreaú, situado no estado do Ceará, localizado na microrregião de Coreaú, mesorregião do Noroeste Cearense. Segundo dados do IBGE, sua população estimada em 2017 é de 23.107 habitantes, sua área é de $775,7 \mathrm{~km}^{2}$. O topônimo tem origem no tupi-guarani cúria (ave aquática de pequeno porte) mais iu (beber) e significa: Águas dos Curiós, a ceva dos curiás. Sua denominação original era Várzea Grande, depois Palma e desde 1943, Coreaú. Nessa conjuntura, a partir do século XVIII com a expansão da produção da pecuária do Ceará, surge uma fazenda e ao redor desta um núcleo urbano conhecido como Fazenda Várzea Grande, vinculado à vila de Granja. O município tem 4 distritos: Coreaú (sede), Araquém, Aroeiras, Canto e Ubaúna e suas diversas localidades. Sua economia ainda hoje é voltada para a agricultura por ser uma cidade do interior do estado e não ter outra fonte de renda para subsistência dos trabalhadores. Sempre teve sua economia voltada para agricultura, coube com a iniciativa da Igreja Católica em 1965, a criação do Sindicato dos Trabalhadores Rurais de Coreaú - STRC, para tornar essa classe trabalhadora organizada e que fosse a principal fonte de renda no campo do município. 
Por outro lado, buscaremos evidenciar como são construídas as "alternativas" geradas pela organização sindical na busca por melhorias, direitos e segmentos com o intuito de amenizar os problemas enfrentados por esta classe trabalhadora. Seja nos grandes municípios ou nos pequenos, as formas utilizadas para organizar os camponeses tiveram princípios semelhantes, mas foram adaptadas em alguns momentos para se enquadrar em determinadas regiões. Assim, concluímos que os sindicatos rurais e as associações que desenvolveram atividades voltadas para o campo foram fruto de lutas e estratégias dos agricultores que tiveram coragem de enfrentar os latifundiários. Por outro lado, mesmo com todas essas lutas, a concentração de terra e o desrespeito ao trabalhador rural ainda se mostram presentes nos dias atuais.

\section{A busca pela formação e organização sindical}

O Brasil é um país marcado por uma grande quantidade de pessoas com condições de vida e de trabalho camponesas, ou seja, trabalhadores rurais pobres que vivem somente da agricultura, do trabalho no campo para sustentarem suas famílias. Até hoje vivem na luta por melhores condições de vida. Pautadas nesse aspecto, a riqueza e a miséria convivem em espaços muito distantes no cotidiano, apresentando grandes índices de desigualdades que, de alguma forma, estão na base da formação dos movimentos sociais.

Situando o processo de formação sindical rural por volta da década de 1960, temos os grandes latifundiários com suas grandes plantações e criatórios de gado. Com pouca terra para trabalhar e sendo explorado diretamente pelos grandes proprietários, temos o agricultor, o sem-terra, aquele que precisa de um lugar para produzir sua alimentação, na qual vai depender do grande proprietário, arrendar sua terra e fazer sua roça e com isso sobreviver, dando parte desta produção para o dono da terra, que já faz é importar aquilo que ele produz. Assim, neste território chamado Brasil, existem realidades sociais e econômicas muito diferentes entre si e um índice de desigualdade enorme que perdura até os dias de hoje.

A luta por melhores condições de vida do homem do campo, posseiros e agricultores, culminou com a luta pela terra, pela posse da terra sobre os domínios dos fazendeiros, dos grandes proprietários de terras. No passado, período de ocupação do Brasil, sabemos que os colonos entraram em territórios habitados pelos índios, dando início às lutas dos nativos contra os poderosos que atropelaram os seus direitos. Assim, vemos que esse processo de imposição e disputa da elite sobre os camponeses, a classe menos favorecida, vem desde o processo de conquista dos portugueses.

Assim, nessa perspectiva, a história do Brasil é marcada por muitos conflitos entre brancos e camponeses e a causa destes conflitos era a luta por 
terras, por direitos negados, tomados. Também pela implantação do projeto da reforma agrária, começaram então as resistências, as revoltas, as lutas camponesas, começando a se organizarem, a se unirem.

Deste modo, a partir de meados da década de 1950 surgiram as primeiras Ligas Camponesas no Brasil, emergindo na cena política diferentes categorias de trabalhadores em luta, com conotação de um movimento radical de contestação ao sistema de monocultura, à mecanização e à estrutura fundiária, que tomava o nome de latifúndio, sinônimo não só de grande propriedade, mas também das formas de dominação e opressão. Não se tratava apenas de um movimento camponês, pois estava envolvido nessa formação o Partido Comunista Brasileiro (PCB), que tinha sido legalizado recentemente. Como podemos perceber, o Partido Comunista Brasileiro buscava ganhar espaço no campo e, por outro lado, temos a necessidade dos camponeses em buscar um meio para lutar pelos seus direitos. Assim, as primeiras ligas começaram a ganhar corpo. Melo e Silva nos fala:

[...] não se deu apenas para mobilizar o campesinato em torno da questão da terra e dos problemas agrários na zona rural brasileira, mas, sobretudo na tentativa de expandir sua área de influência do meio urbano para o meio rural gerando desta forma um elo entre operários e camponeses, além de possibilitar assim, sua luta contra o latifúndio e o imperialismo, pontos definidos como relevantes em seus congressos ${ }^{3}$.

Porém, a institucionalização dessas Ligas Camponesas não chegava a ameaçar a ordem do controle do Estado, colocando em xeque a "ordem" institucional, mas aproveitando-se de todos os canais legais existentes para encaminhar com suas lutas e, em curto período de existência, já se alastravam por várias cidades e alguns estados pelo país, causando um descontentamento entre aqueles que tinham o poder sob seu controle, pois com esse início de organização, já se sentiam ameaçados.

Criou-se um ambiente de discussões e disputas políticas em torno das Ligas Camponesas, tendo o advogado e deputado Francisco Julião à frente de amplos aspectos nos movimentos. Defensor da causa dos camponeses, Francisco Julião, que também era membro do Partido Socialista Brasileiro (PSB), passava para o movimento uma nova impressão, a de que não estava somente representando aquele grupo de trabalhadores. Montenegro nos diz:

Num curto espaço de tempo transformará essa luta numa bandeira de todos os trabalhadores rurais do Nordeste e do Brasil. [...] Transformam-se, segundo grande parte da imprensa, dos

MELO E SILVA, Thiago Moreira. A presença das Ligas Camponesas na região Nordeste. Anais do XIX Encontro Nacional de Geografia Agrária, São Paulo, 2009, pp. 1-29. 
políticos e mesmo da sociedade civil, numa grande ameaça à ordem social e sobretudo à 'paz agrária' dos latifundiários4 .

Com isso, as associações eram criadas e dirigidas por membros de partidos políticos. Temos o (PCB) Partido Comunista Brasileiro, que teve participação ativa nesse processo, bem como na ULTAB (União dos Lavradores e Trabalhadores Agrícolas do Brasil), que deu um outro patamar a esse movimento. As Ligas Camponesas, no entanto, não empreenderam maiores esforços na formação de sindicatos oficiais, privilegiando, nos anos 1960, organizações livres e autônomas. Portanto, conforme considera Leonilde Medeiros:

Das forças que procuraram articular o movimento camponês, quatro grandes linhas se configuram: o PC, que colocava a luta pela terra como componente para a revolução democrático-burguesa, as Ligas que realçavam o potencial revolucionário da luta pela terra enfatizando o papel do campesinato, os setores moderados da Igreja que viam na luta pela reforma agrária moderada as condições para 'se fazer a revolução antes que o povo a faça', e, finalmente, os católicos radicais, que surgiram no movimento camponês já em seu período final e que tinham como proposta tentar buscar o 'ideal histórico' do movimento ${ }^{5}$.

Esses movimentos sociais ligam-se às ações coletivas feitas por grupos padronizados com perseverança de mudanças sociais através de embate político, em favor de seus princípios e ideologias que consistem em determinada sociedade e de âmbito exclusivo, intercalados por preocupações sociais. Pois, em meados do século XX, temos a formação de diversos sindicatos tanto rurais como também de operários, assim, podemos analisar este aspecto dentro de um contexto histórico, relacionando um ao outro.

O processo de constitucionalização dos Sindicatos dos Trabalhadores Rurais no Ceará se deu através de diversos fatores que aconteceram e foram contribuindo para que ganhassem experiência na forma de organização principalmente através das Ligas Camponesas. Além disso, surgiram outros setores que buscavam a sindicalização rural para contornar os problemas que viviam surgindo no campo, e que não eram poucos. Segundo Denise Silva:

A propagação do ideário comunista constituía-se em uma das preocupações de alguns setores da igreja Católica, fazendo com

MONTENEGRO. Antônio Torres. As Ligas Camponesas e os conflitos campo. Saeculum, Paraíba. Cf. Nota 8, p. 14.

5 MEDEIROS, Leonilde Servolo de. A questão da reforma agrária no Brasil. (1945-1964). São Paulo: Dissertação de Mestrado/USP, 1982, p. 141. 
que esta se propusesse a levar adiante a criação de sindicatos de trabalhadores rurais para impedir a formação das Ligas Camponesas. [...] esse momento era muito oportuno para a Igreja Católica, quando esta já vinha desenvolvendo desde a segunda metade da década 1940 trabalhos sócio-educativos com as populações rurais ${ }^{6}$.

Além disso, no começo da década de 1960, outro fator que contribuiu foi a dissolução das Ligas Camponesas, através de fatores internos entre os seus líderes, nas ideias divergentes que pensavam como deveriam ser organizadas as ligas. Isso fez com que a busca pela sindicalização ganhasse ainda mais espaço como meio para fortalecer as reivindicações dos camponeses e fornecessem uma base jurídica, inserindo as reivindicações dentro dos trâmites legais, que eram propostos naquela época.

Mas logo no início da década de 1960 seria interrompida com o golpe militar que derrubou o governo de João Goulart e iniciou a ditadura militar e que afetou esse processo em todo o território nacional, inclusive no Ceará, impondo novas leis e prendendo aqueles que se manifestavam contra o novo governo. Com isso, as criações de sindicatos pelo país passaram a ter dificuldades e sendo impostos novos controles sobre suas criações.

Nesse estudo, podemos perceber que o contexto da formação sindical cearense, na qual a formação dos sindicatos surgiu na década de 1920, não eram ainda sindicatos rurais, mas sim, já se tratava de fortalecer os trabalhadores na busca por direitos. Nesse caso, primeiramente os trabalhadores urbanos, sejam eles assalariados, pescadores ou lavradores, os sindicatos tinham como idealizadores os representantes da igreja. Nessa linha de pensamento, segundo o sociólogo Ronald Albuquerque:

As primeiras organizações sindicais no Estado do Ceará, são ainda da década de vinte, quando a igreja católica, seguindo a orientação emanada da Rerum Novarum passa a atuar no contexto da sociedade civil [...] Dessa maneira levantava as condições de vida e trabalho dos operários organizando-os em entidades sobre direção da própria igreja, como era o caso dos círculos operários e das agremiações ligadas a Legião Cearense do Trabalho ${ }^{7}$.

Nessa perspectiva, podemos constatar que em relação ao campo ainda não estavam sendo estruturados projetos para organizar os trabalhadores.

$6 \quad$ SILVA, Denise Maria Melo da. Desafios e limites da prática política do sindicalismo rural: Um estudo de um caso em São Paulo do Potengir / RN. 147 f. Dissertação (Mestrado em Serviço Social), Universidade Federal do Rio Grande do Norte, Rio grande do Norte, 2006, p. 25.

7 ALBUQUERQUE, Ronald Figueiredo. Igreja, Sindicatos e a organização dos trabalhadores. $205 \mathrm{f}$. Dissertação (Mestrado em Sociologia), Universidade Federal do Ceará, Fortaleza, 1991, p. 97-98. 
Nesse momento, o interior era uma grande extensão de terra com populações que, em sua maioria, viviam muito afastadas uma das outras e suas atividades estavam diretamente ligadas ao clima. Por isso, em períodos de secas e no verão, muitas atividades paravam, as dificuldades dificultavam a sociedade rural em si, tanto pela falta da contribuição, ajuda do governo, mas principalmente da organização social, da falta de organização sindical em busca de melhorias, de melhores condições de vida, faltava o papel de liderança, de incentivador e representativo dos sindicatos rurais.

A forma como o homem do campo via o dono da terra foi um dos fatores preponderantes que marcaram esse processo de criação e organização, pois o fato deles poderem trabalhar e viver na terra do patrão acabava criando uma ideologia que tornava o proprietário uma espécie de um "homem bom", mesmo que o trabalhador rural não tivesse nenhum direito sobre a terra, mas existia aquele medo, respeito pelo senhor da terra.

Com isso, esse fato fez com que os trabalhadores fossem submetidos aos interesses dos proprietários, a não buscarem meios para se organizarem por terem em mente a lealdade ao patrão. A própria Igreja Católica favorecia essa estrutura, causando um retardamento no contexto de formação e ideologização do sindicato, face ao meio de convivência não lhe dar chances de tomar atitude e partir para a luta em busca de seus direitos.

Toda essa estrutura foi fortalecida pela cultura do sertanejo, que buscava respeitar aquilo que ele tinha como honra, ou seja, servir ao seu patrão sem questionar a sua própria existência de explorado. Isso era fruto da forma como se estabeleciam as relações no sertão, onde qualquer ato desagradável para com o patrão era considerado um ato imoral, estruturando-se a partir daí uma ideologia dominante.

Nessa contextualização, na sua maioria os trabalhadores rurais não tinham onde produzir sua safra e dependiam da terra para trabalhar, pois as terras estavam concentradas nas mãos dos fazendeiros, ou eles trabalhavam na terra do proprietário rural, e com isso pagavam renda exorbitante, ou alguns deles moravam nas terras destes proprietários e, com isso, ficavam à sua mercê, das suas ordens. Nesse período não havia uma organização sindical, trabalhavam desorganizadamente. Com isso não havia união, pensamento de organização em busca de melhores condições de vida e de trabalho. Foi com o despertar de líderes sindicais, sejam eles de partidos políticos ou da organização da Igreja Católica, que começou a busca por direitos, que no decorrer dos anos, passa a ser significativa.

Portanto, nesse contexto, a formação de associações começa a consolidar-se e será um dos principais motivos que influenciarão definitivamente a opção por esse tipo de organização, que terá as dificuldades legais para a criação desses sindicatos. Pois era necessária certa quantidade de pessoas 
para ser de fato uma instância sindical, exigência da mesma legislação, que dificultava todo esse processo de serem postos em legalidade, pois o governo deixava organizar, criar um sindicato, mas que deveria seguir as normas regidas pelo governo, pelo ministério, mais precisamente durante o Estado Novo foram criados mecanismos de controle suficientes para manter atrelada a estrutura sindical ao Estado.

Nesse ideário, eram fundamentais para o Ceará essas indicações do PCB, já que o nosso estado tinha como característica na época ser uma área em que predominava a atividade agrícola. Como vivemos em um estado da região Nordeste do país, a agricultura e a pecuária na economia cearense, no tocante a renda, eram e ainda são muito importantes, um dado interessante porque indica o tipo de crescimento econômico que se está processando no estado, assim como o papel que ela cumpre na determinação da população economicamente ativa, o poder da oligarquia agrária, o poder financeiro e político que os fazendeiros tinham naquele tempo.

Foi, portanto, que aparentemente se propiciou a proliferação das associações, com a fundação da União dos Lavradores e Trabalhadores Agrícolas do Brasil (ULTAB), criada no Ceará, e a União dos Lavradores e Trabalhadores Agrícolas do Ceará (ULTAC) em 1955. Para sua fundação, contou com associações do interior do estado, o que demonstrava a expansão da organização dos trabalhadores rurais e sua representatividade que passaria a se consoli- $\mid 109$ dar.

No entanto, essas associações estavam dispostas a lutar pelos direitos dos trabalhadores, ou mesmo que eles tivessem uma base significativa a ponto de modificar o perfil das relações de produção do interior cearense. É de se supor que em tão curto espaço de tempo não se constituísse uma base capaz de compreender as razões da exploração a que estavam submetidos, da mesma forma que seriam incapazes de perceber a necessidade da luta contra a propriedade privada da terra, que era o grande empecilho dos movimentos e lutas.

Desta maneira, a luta pela hegemonia na organização sindical permitirá um redimensionamento da luta política com uma presença constante dos trabalhadores na vida institucional do país, disputando cargos e reivindicando leis protetoras do trabalho contra o capital. Poderia acrescentar que a presença comunista dará maior consistência, apesar do controle que passará a ser exercido pelo partido comunista brasileiro sobre a classe em formação.

\section{Formação sindical e seu processo de organização}

O processo de formação do Sindicato dos Trabalhadores Rurais de Coreaú (STRC) teve o pontapé inicial, quando da sua criação, por volta da dé- 
cada de 1960. Constituiu-se através de pequenas reuniões que caminharam para a formação da organização dos trabalhadores, onde no início de 1965 a ideia de construírem o meio de se organizarem foi concretizada. Isso só foi possível graças a um treinamento um ano antes de um de seus fundadores, idealizado pelo vigário de Coreaú à época, Padre Pontes, da Diocese de Sobral, como apoio das Comunidades Eclesiais de Bases (CEB). No arquivo que se encontra nas dependências na sede do STRC, em documento escrito em 2005, por ocasião da comemoração dos seus 40 anos, temos o registro que nos diz:

Dia 15 de agosto de 1964, o jovem Antônio Machado de Albuquerque, que nasceu e criou-se na localidade Escalvado, deste município, chegara em sua residência, encontrando uma carta do Vigário da Paróquia, Pe. Pontes, cuja carta convidava-o para participar de um treinamento sobre SINDICALISMO. O encontro foi realizado de 05 a 11 de outubro de 1964. De Coreaú foram 04 pessoas: Antônio Machado de Albuquerque, Edemar Teles Moreira, José Francisco de Menezes (Zé Lolosio) e Francisco das Chagas Montezuma (Chico Anjo) ${ }^{8}$.

De início o sindicato tinha o objetivo de manter o controle e "poder" 110 sobre essa classe trabalhadora. Na época, o Ministro do Trabalho e da Previdência Social era o Dr. Júlio Barata, e Emílio Garrastazu Médici, o Presidente da República. Oficialmente publicados os atos de criação dos sindicatos no Diário Oficial da União, objetivava o governo ter um controle sobre as pessoas que conviviam no campo, e com sua legalização com a intermediação da Igreja, os sindicatos se tornavam como algo mais benéfico e controlador daquelas pessoas tão distantes e desinformadas, que poderiam se dispersar ou se revelarem contra o governo.

Para a formação do Sindicato dos Trabalhadores Rurais de Coreaú, como vimos anteriormente, contou-se com a presença e participação da Igreja Católica, com o vigário da Paróquia, Pe. Pontes, cuja carta convidava alguns letrados da época para participar de um treinamento sobre SINDICALISMO. O encontro foi realizado em 1964; de Coreaú foram alguns representantes, pessoas que foram os idealizadores da criação do sindicato, do qual se tornaram membros por vários anos, dentre os quais o ainda jovem na época, Antônio Machado de Albuquerque, que participava das Comunidades Eclesiais de Base e perdurou como representante sindical até por volta de 2008, mas que continua sob a liderança de membros da sua família.

O membro atual da direção do sindicato, Antônio Machado de Albuquerque Neto, que é neto de um dos integrantes que participou do treinamento 
para a criação sindical em 1965, nos fala desse processo inicial do sindicato, que era mais de assistencialismo, forma de sindicalismo da época vinculados à Igreja e não de luta sindical, propriamente dita:

Por causa da representação das comunidades eclesiásticas, a Igreja propôs a criação do sindicato, posso assim dizer [...] que era só o nome, porque como fosse assim uma associação qualquer; não tinha credibilidade, não tinha poderes, porque era representativa [...] a gente assim [...] a população ainda não conhecia o que era sindicalismo, tanto que essa sede aqui só foi construída, terminada uns 10 anos depois da fundação do sindicato $[\ldots]^{9}$.

Por conseguinte, com o passar dos anos de forma destacada, o sindicato ganhou adesões por trazer benefícios, entre eles bolsas, consultas, assistência médica para aquelas pessoas que eram esquecidas pelo governo. O historiador Antônio Francisco relata em sua monografia como se deu esse processo, da sua importância, dos benefícios conseguidos, como se fosse o programa do Sistema Único de Saúde (SUS) de hoje. Mas que não chegava a ser um programa, e sim um meio assistencialista para manter aquele grupo de pessoas envolvidas com aquele projeto, que de certa forma era político, pois era idealizado pela Igreja e com o apoio dos governos ditatoriais na época, beneficiando essa classe, por ser uma alternativa que ajudava na sua subsistência:

No campo da educação, houve também algumas conquistas que aconteceram na década de 1970 por intermédio do Programa Especial de Bolsa de Estudo (PEBE), que ofertou 120 bolsas para filhos dos associados. Estes buscavam alguma formação para os filhos dos agricultores, em um momento no qual a educação coreauense era muito restrita. Devemos ressaltar que não era um benefício que atendia a todos; a demanda era muito grande e muitos pais queriam que os filhos tivessem oportunidade de ter uma formação ${ }^{10}$.

Os contatos com a comunidade visando à sindicalização eram anunciados nas igrejas através das missas. Neste sentido, a Igreja aproveitava-se bem de uma estrutura com profundas raízes nas populações rurais. Quando chegava às comunidades, tinha trabalhadores a esperar seus anunciadores, sempre atentos às suas palavras e seguindo suas ideologias. Vejamos como

9 Antônio Machado de Albuquerque Neto, 24 anos, agricultor. Entrevista realizada pelo autor em 28 de agosto de 2018. Coreaú-CE.

10 SOUZA, Francisco Antônio. Morrer na luta é heroísmo. Fugir da luta é covardia. O processo de organização e das lutas dos agricultores em Coreaú-CE (1965 - 1988). Monografia. Universidade Estadual Vale do Acaraú, 2018, p. 37. 
destacou o entrevistado Antônio Machado de Neto sobre o sindicalismo vinculado à Igreja:

A Liga Camponesa tinha mais um perfil de luta do que o próprio sindicato [...] porque no início do sindicalismo ligado à ala da Igreja, ele foi permitido pela ditadura, pelos governos da ditadura [...] então eles tinham aquela ideia de querer de alguma forma ter o controle, entendeu, dos movimentos sociais. Aí eles permitiram nesse sentido [...] porque naquela época tinha médico, tinha dentista, tinha farmácia, era o que eles chamam de sindicalismo amarelo ou o sindicalismo pelego, que era um sindicalismo muito mais assistencial do que um sindicalismo de luta, de movimento, por ter se gerado com a iniciativa da Igreja $^{11}$.

Com o passar dos anos, sentiu-se a necessidade de lutar. Falava-se então da necessidade de organização dos trabalhadores no sindicato, com o objetivo de lutar, participar juntamente com as outras organizações, dos movimentos sindicais, sejam nas frentes estadual ou federal. Havia a necessidade de união de todos em benefício da coletividade. Com os objetivos dos movimentos de lutas liderados pelo movimento sindical, passou-se a ter uma nova realidade nas vidas de homens e mulheres trabalhadoras rurais.

A princípio, isto se dava na organização dos sindicatos da região, que contou com o apoio de alguns proprietários que eram a favor dessa criação, mas isso não era algo corriqueiro. Mesmo sendo os sindicatos ligados à Igreja, vários donos de terra ameaçavam seus empregados, criando as primeiras dificuldades numa região que não conhecia, até então, nenhuma mobilização de trabalhadores rurais. Os grandes latifundiários sabiam que estava se criando algo benéfico aos trabalhadores e não para a sua classe, mesmo sendo o sindicato uma entidade com feição assistencialista, organização conjunta com a Igreja Católica e o governo, precavendo-se do avanço comunista que se instalava em todo o estado.

Os trabalhadores continuavam sem ter terra para cultivar, a não ser aqueles que tinham algum grau de compatibilidade com alguns donos de terras, ou seja, trabalhando constantemente para aquele proprietário e ganhando uma pequena quantia em dinheiro, ou alimentos como forma de pagamento, submetendo-se à proteção de um proprietário de terra. Com isso, eles cediam a terra para cultivo, mas ainda existindo o pagamento da renda por aquilo que foi colhido.

Neste caso, tinha a casa e uma área para plantar o feijão, o milho, a mandioca e outras sementes de plantio para seu sustento. Durante as moagens,

${ }_{11}$ Entrevista concedida por Antônio Machado de Albuquerque Neto, 24 anos, agricultor. Em 28.08.2018. 
recebiam alimentação e um salário suficiente apenas para o atendimento de algumas necessidades mais imediatas, eram apenas o mínimo, não reconheciam seus direitos que eram estabelecidos por lei e que não eram seguidas. Mas, com o passar dos anos e a participação ativa do sindicato nos movimentos, ou seja, a idealização dos movimentos sociais por todo o país, esse quadro começou a mudar. Começaram a propor políticas voltadas para o homem do campo, juntamente com a Igreja, com o objetivo de conter o avanço comunista que se estabelecia sobre esse movimento.

O partido comunista passaria a ter representação política nos partidos de esquerda dentro desses movimentos sindicais, travando assim uma disputa pela liderança e o controle desses movimentos. Depois veio o Partido dos Trabalhadores (PT), que passou a ter uma maior visibilidade e consequentemente maior representatividade, não só o sindicato dos trabalhadores rurais, mas também com o sindicato dos metalúrgicos, ganhando mais representação tanto em Brasília, no Congresso Nacional, como também nas Assembleias Legislativas.

No entanto, o crescimento e a extensão das delegacias dos sindicatos nos distritos e localidades do município, permitiu inclusive que fossem informadas às diretorias dos problemas existentes nas bases, ao mesmo tempo em que serviu de espaço para a ampliação das questões referentes à categoria. Neste caso, se dá um processo de comunicação das ações dos sindicatos, permitindo que fiquem os trabalhadores informados das ações existentes em toda área abrangida pelo sindicato, formando, portanto, uma rede de informações e discussões que facilitasse o trabalho de ampliação dos quadros sindicais.

Também para melhor informação, e com o passar dos anos, passou-se a ter um programa no rádio aos sábados, que tinha o objetivo de melhorar a divulgação e a informação aos associados, que durou vários anos. Este tipo de assistencialismo pode ser visto nos documentos do sindicato:

Em 1971 conseguimos gabinete odontológico. Em 1993 conseguimos ambulatório médico que funcionou por muitos anos. Em 1973 conseguimos 120 bolsas de Estudo pelo PEBE (Programa Especial de Bolsas de Estudo), tendo sido beneficiados durante muitos anos, filhos de associados. Hoje tem sócios cidadãos formados. Nossa primeira vitória foi após a Fundação ter impedido que 328 famílias de Trabalhadores Rurais, não pagassem renda em uma área de terra da União e conseguido a titulação para os trabalhadores rurais de Feitoria ${ }^{12}$.

Nessa relação, entre rádio, Igreja e educação dos trabalhadores, o Movimento de Educação de Base (MEB), foi uma referência na prestação de serviços de educação de base e alfabetização de jovens e adultos para as po-

12 Relatório. 2005. Arquivo do Sindicato dos Trabalhadores Rurais de Coreaú-CE. 
pulações excluídas da sociedade. E também na criação de associações comunitárias. O rádio foi um veículo de comunicação muito importante de fortalecimento do movimento e da Igreja, por meio das rádios pertencentes às igrejas. A Historiadora Viviane Bezerra Prado nos revela esses fatos em sua pesquisa:

Integrada a essa orientação, situam-se as emissoras católicas Rádio Educadora do Nordeste, de Sobral, apoiando os programas Encontro com o MEB e Encontro das Comunidades, do Movimento do Dia do Senhor, e Rádio Assunção, de Fortaleza, veiculando o programa do MEB estadual, A Escola em sua Casa, em sintonia com as propostas assumidas pela Igreja Povo, com vistas ao desenvolvimento integral do meio rural ${ }^{13}$.

Com o advento das forças sindicais pelo país, mesmo no regime militar, o movimento sindical foi fundamental no processo de derrubada da ditadura que, com a participação e direção da Confederação Nacional dos Trabalhadores Rurais Agricultores e Agricultoras Familiares (CONTAG), e da Federação dos Trabalhadores Rurais Agricultores e Agricultoras Familiares do Estado do Ceará, (FETRAECE), estas, apesar de estarem sob intervenção, continuavam levantando propostas como a reforma agrária e o cumprimento da Legislação Trabalhista no campo. A união de todos e de centrais sindicais como a CONTAG foi preponderante para esse avanço nas conquistas que chegavam para o homem do campo.

\section{A Igreja como idealizadora da formação sindical em Coreaú}

O processo da organização dos trabalhadores facilitou a aproximação da Igreja Católica com a burguesia dominante, até porque a reação do catolicismo é de disputar as massas no contexto de suas lutas, de sua organização, elaborando uma doutrina de complementariedade das classes no sentido de promover o bem-estar da sociedade. Para isso, conta com a sua estrutura que é ampliada de forma a se fazer mais presente entre as camadas mais pobres, que era muito carente desse convívio e envolvimento com a sociedade, e de começar a ter participação ativa nesse processo de idealização. Nessa contextualização, a historiadora Viviane Prado Bezerra nos relata como se deu esse processo da participação da Igreja e do partido político nesse processo:

Assim, a Igreja Católica atua no campo de disputas pela organização e orientação política - ideológica da classe trabalhadora. A década de 1960 constitui um período de lutas e

13 BEZERRA, Viviane Prado. "A Igreja está ao lado da libertação": experiência de uma pastoral popular no contexto da ditadura militar no Ceará. Revista Historiar, Sobral, ano II, n. I, 2010, p. 88. 
manifestações populares que atrai cada vez mais o apoio de grupos de esquerda. A atuação do Partido Comunista Brasileiro (PCB) e a formação das ligas camponesas ajudaram na articulação dos camponeses atraindo, para o campo, a atenção do governo e de latifundiários, que viam, na reinvindicação pela reforma agrária, ameaça aos seus interesses ${ }^{14}$.

Nesse momento, a Igreja Católica começou a voltar seus projetos para o campo, criticando as relações que se mostravam fortalecidas mesmo com as transformações sociais e tecnológicas. Neste contexto, o campo estava buscando se inserir na nova modalidade de capital associado à tecnologia, voltada para o lucro e exploração do trabalho. Nascimento aponta isso na sua fala:

A partir da década de 1970, a Igreja lança documentos críticos em relação ao problema da terra no Brasil. A crítica da Igreja se dirigia ao processo de acumulação e especulação do capital da terra que foi utilizado amplamente pelas empresas modernas com técnicos sofisticados, mas que também, com a utilização da escravidão, principalmente, a escravidão por dívidas no regime de peonagem ${ }^{15}$.

Acentua-se, nesse processo, a organização dos trabalhadores rurais de Coreaú, que teve início em meados da década de 1960, momento em que a 115 luta no campo começou a ganhar força. Esse processo teve forte influência da Igreja católica, especificamente da Diocese de Sobral, que se tratava, ao mesmo tempo, de duas vertentes: uma busca pela organização dos camponeses e a outra embasada em uma ideologia política contra o comunismo, onde se tinha o Movimento de Educação de Base (MEB). A historiadora Viviane Prado Bezerra nos diz:

O sindicalismo e a reforma agrária despontam como uma questão de relevo em documentos episcopais desde a Rerum Novarum. Esses temas são tratados pela Doutrina Social da Igreja, como alternativa ao projeto de sociedade do socialismo e comunismo. De acordo com a Doutrina, os sindicatos eram permitidos, sem desvio de suas 'finalidades legítimas': organização e reivindicação dos trabalhadores de forma pacífica, com harmonia entre patrões e trabalhadores, capital e trabalho ${ }^{16}$.

14 BEZERRA, Viviane Prado. Dissertação de Mestrado. Por que se nós não agir o pudê não sabe que nóis isiste nu mundo: O MEB e o dia do senhor em sobral. (1960 - 1980). Universidade Federal do Ceará, 2008, p. 18.

15 NASCIMENTO, Claudemiro Godoy. Educação do campo e políticas públicas para além do capital: Hegemonia em disputa. 301 f. Tese (Doutorado em Educação), Universidade de Brasília, Brasília, 2009, p. 127.

16 BEZERRA, Viviane Prado. "A igreja está ao lado da libertação": experiência de uma pastoral popular no contexto da ditadura militar no Ceará. Revista Historiar, Sobral, ano II, n. I, 2010, p.84. 
Faz-se importante ressaltar que o princípio da organização seguiu as orientações estabelecidas pela Igreja e não se tratava ainda de fortalecer a luta por transformações, mas sim de uma organização harmoniosa. Não se buscava, nesse momento, de enfrentar os grandes proprietários ou mudar a relação exploratória do trabalhador, mas apenas organizar os trabalhadores em uma categoria com representatividade, nesse caso, o sindicato.

Desta maneira, a Igreja tinha participação no processo de organização do campo, que naquele momento tinha caráter urgente. A dependência que se estabelecia entre trabalhador sem-terra com o proprietário da terra somente poderia derivar da gratidão, respeito por aquele que dava sua terra para sua produção, tanto que nem despertavam o interesse de buscar lutar por seus direitos.

\section{Considerações Finais}

Podemos observar que desde o processo de ocupação, as terras foram privilégio das famílias tradicionais, um fato que ainda se mostrava vivo na década de 1960 e se mantém atualmente em algumas comunidades. Nessa mesma situação, temos a ocupação dos escravos que tinham convivência direta com seus patrões, motivada pelas atividades executadas na região. Fazendo um paralelo entre os fatos estabelecidos nas relações no século XX com o que se apresentava no início da colonização, compreendemos que a exploração do trabalho e o acesso à terra eram ainda resquícios que têm suas raízes no Brasil Colônia.

Com isso, percebemos como o sindicato dos trabalhadores rurais, tanto em nível nacional, estadual e municipal participou e lutou arduamente nesse processo de transformação e melhoramento na vida daqueles que trabalham no campo. Toda essa trajetória é fruto de organização, força de vontade, trabalho com sinceridade, dignidade, honestidade e perseverança.

Ao longo de todos esses anos, a atuação do sindicato contribuiu e contribui para a ampliação e o fortalecimento da organização, representação e coordenação da defesa dos direitos classistas (trabalhadores rurais), da agricultura familiar. Sempre reivindicando, propondo e negociando políticas agrícolas diferenciadas, direitos previdenciários dos trabalhadores e trabalhadoras rurais e políticas sociais que resgatam a área rural, enquanto espaço de vida, de trabalho, luta e construção de conhecimentos capazes de promover as transformações necessárias para o desenvolvimento sustentável da categoria.

\section{Fonte oral:}




\section{Documentos impressos:}

Arquivo do Sindicato dos Trabalhadores de Coreaú.

Relatórios produzidos pelo Sindicato dos Trabalhadores Rurais de Coreaú.

Transcrição da Carta Sindical, Arquivo do Sindicato dos trabalhadores Rurais de Coreaú. 



\title{
10. O Ensino de História e cultura indígena em Hidrolândia-CE: a Lei 11.645 de 2008 e os meios para uma descolonização da imagem do indígena
}

\author{
Paulo Ênio de Sousa Melo ${ }^{1}$
}

\section{Introdução}

O presente texto procura trazer algumas questões referentes ao ensino de história, em especial as que têm especial relação com a Lei 11.645 de 10 de março de 2008, o estudo da história e cultura afro-brasileira e indígena em todas as escolas públicas e privadas do Brasil, nas modalidades de ensino fundamental e médio. $\mathrm{O}$ texto apresenta novas abordagens historiográficas dos últimos 30 anos sobre o reconhecimento da história e cultura indígena para a educação básica e na história do Brasil. O intuito é reconhecer os indígenas como protagonistas na história, e não somente a transmissão de imagens idílicas simplistas que reconheciam os indígenas presos a um passado distante a mercê do colonizador.

Nessa perspectiva, apresentamos que se desconheciam os processos históricos vivenciados por estes povos na história nacional. E, também, muitas vezes, não se compreendia a cultura como um processo em construção, assimilações e reelaborações, não sendo fixa. Para tanto, apresentamos um pequeno estudo de caso na escola de ensino fundamental Prefeito Walter Marinho, de Hidrolândia, Ceará, para entendermos como os alunos estão compreendendo sobre os povos indígenas na história da República brasileira. Portanto, para os dados analisados dispomos de uma amostra de 23 alunos, para expor metodologicamente como os povos indígenas são apresentados no ensino, no livro didático, e se as abordagens elencadas apontam para o protagonismo indígena na história.

Hoje, muito se discute sobre os conteúdos dos livros didáticos. Pesquisas recentes têm demonstrado que é preciso repensar o ensino de história, tanto em reformulações de práticas pedagógicas, quanto às ideologias presentes

Graduando do Curso Superior de Licenciatura em História pela Universidade Estadual Vale do Acaraú-UVA. E-mail: pnsousa_100@hotmail.com. 
nos conteúdos, até mesmo a falta de atualização dos conteúdos presentes em forma factual que divergem das que são apresentadas na academia. Desta forma, não se tem uma sincronia quando é transmitido pelos meios didáti$\cos ^{2}$.

Não só os pesquisadores de ensino de história têm demonstrado tais preocupações com as formas de transmissão dos conteúdos e didática para a educação básica, mas também profissionais de outras áreas curriculares têm apresentado sugestões para melhorar o ensino das disciplinas escolares.

As pesquisas desenvolvidas nas faculdades por todo o país têm apresentado novas possiblidades para a atualização e novas formas de utilização dos conteúdos didáticos que perpassam pela autonomia do professor. Por fim, no século XXI, diversos pesquisadores têm desenvolvido novas pesquisas voltadas para a inclusão dos agentes históricos antes invisibilizados pela historiografia tradicional. Portanto, os estudos concernentes à inclusão estão logrando novas questões por um viés interdisciplinar a educação.

Nessa concepção, para o ensino da história e cultura dos povos indígenas, ao longo dos últimos 30 anos têm se desenvolvido novas abordagens historiográficas que mostram o protagonismo indígena. Uma das possibilidades para novas práticas pedagógicas para o ensino de história indígena é a formação continuada do professor regente da disciplina de História, que deve incorporar questões relativas à temática indígena numa perspectiva histórica. As novas análises das relações sociais indígenas que apontam para o protagonismo têm feito uma estreita relação entre a história e antropologia para uma análise crítica dos relatos produzidos pelo homem branco sobre os indígenas, compreendendo associações e negociações.

Partindo dessa perspectiva, a análise das relações sociais e políticas, deste viés historiográfico, passarão a identificar os povos indígenas como protagonistas dentro de vários temas da História de norte a sul do país e, por que não, ao longo da Colônia, Império e República do Brasil? Portanto, com novas posturas serão apontadas a inclusão de variadas formas e ações interpretativas das vivências dos povos autóctones em contato com o homem branco, reconhecendo-os como agentes formadores do Estado Nacional.

Partindo destas questões, apresentamos o ensino da História indígena em Hidrolândia, "situada geograficamente no sertão cearense, a cidade Hidrolândia fica a 250 quilômetros da capital Fortaleza, a mesma faz divisa ao norte com a cidade de Varjota, ao sul limita-se com Tamboril e Nova Russas, ao Leste com a cidade de Santa Quitéria e ao Oeste com a cidade de Ipu e

FEREIRA, Marieta de Moraes; FRANCO, Renato. Estudos Históricos, Rio de Janeiro, vol. 21, nº 41, p. 79-93, jan.-jun. 2008 
Ipueiras." 3 , na Escola Prefeito Walter Marinho, em especial, no $8^{\circ}$ ano do Ensino Fundamental II, no componente curricular História. Ambas as premissas vão ao encontro dos objetivos deste trabalho.

Dessa forma, levantaremos questões relativas ao ensino da história e cultura indígenas propostas pela Lei 11.645 de 10 de março de 2008. Analisaremos também o papel da ação do professor regente da escola de Ensino fundamental e a percepção que os alunos têm sobre a participação dos indígenas na História do Brasil. Em outras palavras, manifestar suas opiniões sobre: quem são eles (os indígenas)? Onde estão?

O texto encontra-se organizado em tópicos para uma melhor compreensão, onde se pretende analisar o ensino de história e cultura indígena em uma das escolas de ensino fundamental de Hidrolândia. Não pretendemos fechar questões sobre o assunto, mas abrir novas possibilidades para o debate.

Para o primeiro tópico, "o ensino de história e cultura indígena na educação básica", faremos uma breve apresentação das novas posturas historiográficas sobre temática indígena e para o ensino da história e cultura indígena para educação básica no século XXI. Logo, trataremos da importância da Lei 11.645 de 2008 para a educação brasileira e novos estudos que têm demonstrado a importância do reconhecimento dos povos indígenas enquanto formadores do Estado Nacional.

Por conseguinte, no segundo tópico, "Os indígenas na República brasileira”, apresentaremos as políticas voltadas ao reconhecimento e participação dos povos indígenas na república brasileira de uma forma geral. Para esta questão faremos um breve apontamento das relações intrínsecas às políticas indigenistas e a temática tratada pela Constituição Federal de 1988.

Por fim, no terceiro tópico, "Qual a imagem dos povos indígenas em instituições de ensino básico?", acrescentamos ao assunto, referente à aplicabilidade da Lei 1.645 de 10 de março de 2008, uma amostra de 23 alunos de $8^{\circ}$ ano do Ensino Fundamental, mostrando se eles estão tendo uma nova postura diante do ensino e se estão apresentando os povos indígenas enquanto protagonistas da história do Brasil.

\section{O Ensino de História e Cultura Indígena na Educação Básica}

As novas propostas para o ensino de história têm levado em consideração o cotidiano dos alunos e o contexto social em que estão inseridos ${ }^{4}$. Desta

BEZERRA, José Genário Mesquita. Vida e sobrevivência nas margens do Araras: (Décadas $1960 \mathrm{e}$ 1970). In: GOMES, Paulo Júnior (org.). Hidrolândia Ceará: Olhares sobre a história de um povo. Fortaleza: Expressão Gráfica e Editora, 2017, p. 278.

4 GUIMARÃES, Selva Fonseca. Didática e prática do ensino de História: experiências, reflexões e aprendizados. $8^{\text {a }}$ ed. Campinas, SP: Papirus, 2003. 
forma, convém se desenvolver no cotidiano escolar métodos que abriguem as novas propostas pedagógicas para o ensino de História, que compreenda os múltiplos agentes históricos, em especial, os povos indígenas na História do Brasil.

Há muito tempo, desde o período de colonização, tem se apresentado uma imagem idílica e esporádica sobre os povos indígenas na História do Brasil. Os indígenas eram aqueles que estavam destinados a serem incorporados à sociedade colonial, imperial e republicana ou a invisibilidade na História. E, entre outras questões, "habitavam" no Brasil em grandes florestas do país. Em meio as tais questões, existia uma grande dificuldade de apresentar os povos indígenas como protagonistas, como proposto pelas novas pesquisas que têm demonstrado a participação dos povos indígenas ao longo da História do Brasil.

O problema que apresentamos, em outras palavras, tinha destinado um lugar muito específico aos povos indígenas na história, o passado. Nessas perspectivas, o Estado Nacional não era visto como formado pelos nativos. E, sob esse ponto de vista, eram negados aos diversos processos históricos que os povos indígenas estiveram por muito tempo imersos neles, que aos poucos foi se instituindo uma ideia sobre o ser índio.

A escrita que vinha se desenvolvendo e o ensino de história sobre os povos indígenas em todo o país tinham destinado às populações indígenas o passado longínquo. O homem branco, do ponto de vista da historiografia do período do início da República no Brasil, tinha destinado os portugueses como os que tomavam todas as decisões. E, por conseguinte, os povos indígenas estariam a mercê daqueles que vieram "colonizar" o Brasil", e que, futuramente, seriam integrados e sumiriam junto a civilização.

A partir da década de 1990, com as produções da historiadora e antropóloga luso-brasileira, Manuela Carneiro da $\mathrm{Cunha}^{6}$, e com os mesmos propósitos, de John Manuel Monteiro ${ }^{7}$, lograram uma nova postura para se compreender a história de contato entre portugueses e indígenas de outra forma interpretativa. Ambos os pesquisadores apontam que a relação estabelecida com o português não pode ser entendida apenas pelo viés ideológico do colonizador. E, por fim, com a antropologia histórica, proposta por João Pa-

Para ver um modelo de como as etnias constitutivas da recém-fundada nação brasileira deveriam aparecer na história, confira a tese de Von Martius. "Como se deve escrever a história do Brasil", trabalho vencedor de um concurso promovido pelo Instituto Histórico e Geográfico Brasileiro (IHGB) em 1840. Disponível em: https://www.jstor.org/stable/20137096?seq=1\#page_scan_tab_contents. Acesso em: 03 out. 2018.

6 CUNHA, Manuela Carneiro da. História dos índios do Brasil. São Paulo: Cia das Letras, 1992.

7 MONTEIRO, John Manuel. Os negros da Terra: índios e bandeirantes nas origens de São Paulo. São Paulo: Companhia das Letras, 1994. 
checo de Oliveira, tem apresentado novas perspectivas para a escrita e entendimento das relações estabelecidas pelos indígenas com os nãos indígenas.

Nesta mesma perspectiva, Luisa Tombini nos mostra que:

Todavia, essa relação entre sujeitos diferentes não deve ser pensada com um choque entre blocos imutáveis, em que os ditos vencidos aparecem como resistentes culturais, sobreviventes descaracterizados à espera do desaparecimento ou já vítimas do extermínio. [...] Podemos recontá-la reconstruindo conflitos, diálogos, tensões e negociações. Uma história na qual são protagonistas percorrem caminhos que eles mesmos construíram ${ }^{8}$.

Como dissemos, atualmente no Brasil essa postura tem se renovado com antropologia histórica, proposta por João Pacheco de Oliveira ${ }^{9}$. Desta forma, é possível atualizar os termos empregados aos indígenas, não relegando somente ao passado, como também uma atualização da história local e nacional referente aos povos indígenas mencionando-os como protagonistas das relações estabelecidas com os não indígenas.

As novas propostas partem de uma análise dos processos históricos vivenciados pelos povos indígenas numa perspectiva histórica. Entre outros termos, é necessário compreender criticamente as fontes produzidas pelo homem branco, e, por meio de uma análise histórica antropológica, tentar se escrever uma história de um ponto de vista em que os povos indígenas sejam os precursores de suas relações. E, além do mais, compreender a cultura e identidade como um processo flexível e dinâmico, passível de transformações ao longo do tempo. Dito de outra forma, a cultura e identidade passam por construções socioculturais e que também são históricas ${ }^{10}$.

Dentro destas ponderações historiográficas, toda a nova produção acadêmica sobre a história dos povos indígenas passou a questionar a participação destes povos na história em todo o país. E, além disso, trouxe novas questões para superar a historiografia desenvolvida ao longo do século XIX.

Com os novos números estatísticos do IBGE do último Censo de 2010, fez cair por terra a ideia de desaparecimento dos povos indígenas do mapa.

8 WITTMANN, Luisa Tombini. Ensino (d) e História indígena. Belo Horizonte: Autêntica Editora, 2015. (Coleção prática docentes).

9 OLIVEIRA, João Pacheco de. O nascimento do Brasil e outros ensaios: "pacificação", regime tutelar e formação de alteridades / João Pacheco de Oliveira. - Rio de Janeiro: Contra Capa, 2016.384 p.: il. color.

10 ALMEIDA, Maria Regina Celestino de. Os índios na história do Brasil. Rio de Janeiro: Editora FGV, 2010. 
Nossa Gente,

Nossa História

o Ceará Republicano

Segundo o último Censo do $\mathrm{IBGE}^{11}$, os povos indígenas têm resistido e demonstrado que estão lutando em todo o país por autonomia na política e por benéficos para educação, saúde e demarcação de suas terras tradicionais. Vejamos no mapa elaborado pelo IBGE sobre as populações indígenas no Brasil no último Censo:

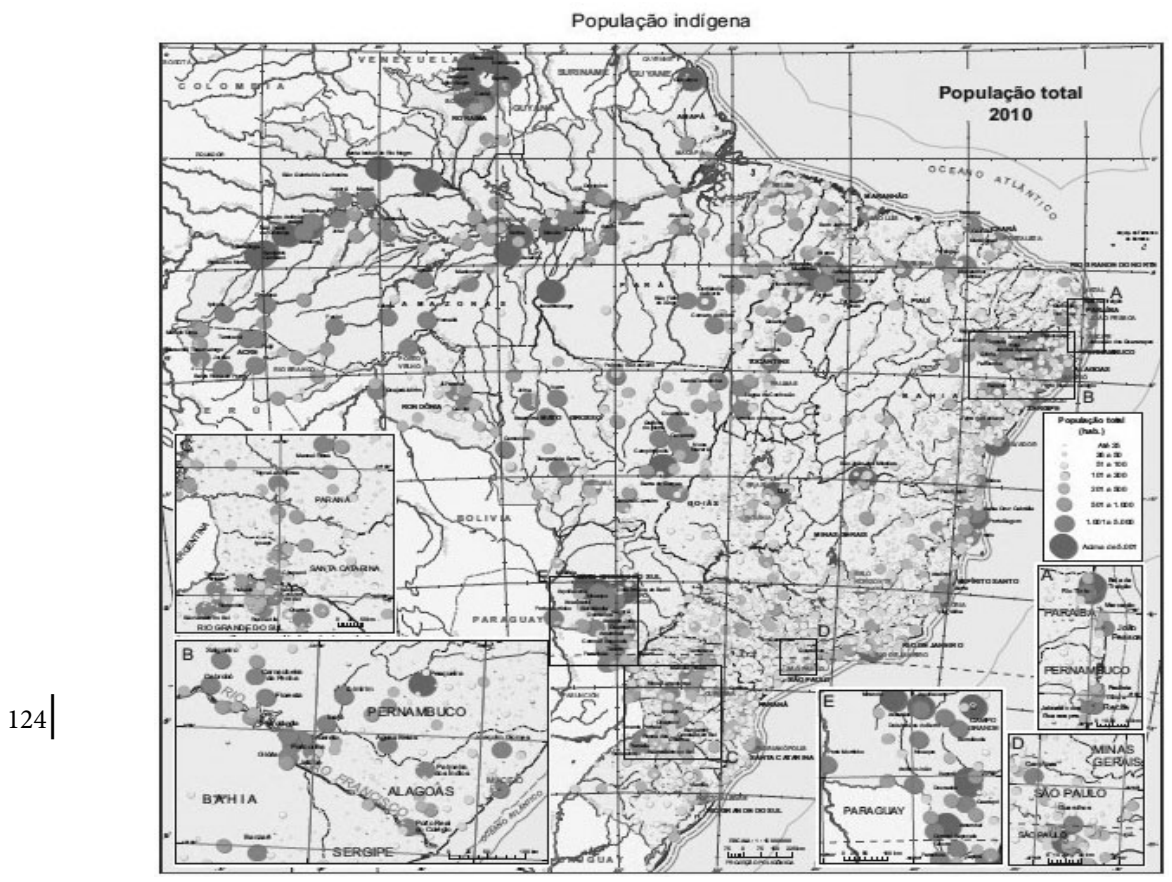

Fonte: IBGE - Indígenas. Disponível em:<https://indigenas.ibge.gov.br/downloads. html> Acesso em: 24 set. 2018

A mudança postulada para a educação brasileira ao longo da República e os processos de redemocratização têm levado ao debate a inclusão das diversas classes sociais para o reconhecimento de suas participações na história ${ }^{12}$. Hoje, tem se questionado a participação dos povos que tiveram poucos reconhecimentos políticos, por meio de lutas. Eventos internacionais e nacionais corroboraram em apresentar uma nova história em nível social, onde se re-

\footnotetext{
11 Censo 2010: população indígena é de 896,9 mil, tem 305 etnias e fala 274 idiomas. No Censo 2010, o IBGE aprimorou a investigação sobre a população indígena no país, investigando o pertencimento étnico e introduzindo critérios de identificação internacionalmente reconhecidos, como a lingua falada no domicílio e a localização geográfica. Foram coletadas informações tanto da população residente nas terras indígenas (fossem indígenas declarados ou não) quanto indígenas declarados fora delas. Para mais informações vide; INSTITUTO BRASILEIRO DE GEOGRAFIA E ESTATÍSTICAS. (Brasil). Censo, 2010. Disponívelem: $<$ https://censo2010.ibge.gov.br/noticiascenso busca $=1 \&$ \&id $=3 \&$ \&idnoticia $=2194 \& \mathrm{t}=$ censo-2010-poblacao-indigena-896-9-mil-tem-305-etnias-fala-274\&view=noticia $>$ Acesso em:< 04/09/2018>.

12 GUIMARÃES, Selva Fonseca. Revisitando a história da disciplina nas últimas décadas do século XX. In: GUIMARÃES, Selva Fonseca, Op. cit., 2003.
} 
conheceu que todos os povos têm história e, de alguma forma, contribuíram e fazem sua própria história ${ }^{13}$.

E, como fruto do reflexo das políticas nacionais e internacionais, a Lei 11. 645 de 2008 tornou obrigatório o ensino da história e cultura dos povos indígenas e atualizou a Lei 10.639 de 2003, que traz o ensino de história e cultura afro-brasileira. A atualização e o reconhecimento da cultura indígena na história do Brasil se apresentam conforme o texto da lei abaixo:

Art. 26-A. Nos estabelecimentos de ensino fundamental e de ensino médio, públicos e privados, torna-se obrigatório o estudo da história e cultura afro-brasileira e indígena.

$\$ 1^{\circ}$. O conteúdo programático a que se refere este artigo incluirá diversos aspectos da história e da cultura que caracterizam a formação da população brasileira, a partir desses dois grupos étnicos, tais como o estudo da história da África e dos africanos, a luta dos negros e dos povos indígenas no Brasil, a cultura negra e indígena brasileira e o negro e o índio na formação da sociedade nacional, resgatando as suas contribuições nas áreas social, econômica e política, pertinentes à história do Brasil.

$\$ 2$. Os conteúdos referentes à história e cultura afrobrasileira e dos povos indígenas brasileiros serão ministrados no âmbito de todo o currículo escolar, em especial nas áreas de educação artística e de literatura e história brasileiras ${ }^{14}$.

Portanto, ainda estamos por construir uma educação onde se ensine uma postura crítica em relação aos povos indígenas na História. Conforme Giovani José da Silva ${ }^{15}$, os professores da educação básica têm que se mobilizar em diversos conteúdos das disciplinas escolares para reconhecimento da história e cultura indígena.

A Lei 11.645 de 10 de março de 2008, como fruto de um bojo de políticas internas e externas, trouxe para o ensino de história um novo sentido para se conhecer a riqueza de cultura e múltiplos povos existentes na história do Brasil. As leis 10.639 e 11.645 perfazem uma atualização significante da Lei de Diretrizes e Bases da Educação Nacional de 20 de Dezembro de 1996 para um país tão plural como o Brasil.

Sobre a produção historiográfica, Santos afirma que "ao longo dos últimos 30 anos, a História Indígena logrou conquistar seu espaço na historio-

13 SILVA, Maria da Penha da. A temática indígena nos anos iniciais do ensino fundamental: um estudo das práticas curriculares docentes em Pesqueira - PE. 2015.311.f. Dissertação (Mestrado) Programa de Pós-Graduação em Educação Contemporânea, Universidade Federal de Pernambuco, 2015.

14 BRASIL. Lei no 11.645 , de 10 de março de 2008. História Indígena e Cultura Afro-Brasileira e Indígena. Brasília - DF, 2008.

15 SILVA, Giovani José da Silva; COSTA, Anna Maria Ribeiro F. M. da. Histórias e culturas indígenas na Educação Básica.1.ed. Belo Horizonte: Autêntica Editora, 2018 (Coleção Práticas Docentes). 
grafia, ainda que o status acadêmico esteja condicionado às iniciativas locais" ${ }^{16}$. Nesse sentido, as produções acadêmicas estão revendo as produções historiográficas, portanto, atualizando os conteúdos direcionados à educação básica em conformidade com a Lei 11.645 de 2008, buscando rever os conceitos fixos no currículo oficial de ensino em relação à efetivação da participação dos povos indígenas na História.

Os materiais didáticos atuais ainda acompanham algumas das ideias produzidas no âmbito do Instituto Histórico e Geográfico Brasileiro (IHGB) no século XIX, como a do intelectual Francisco Adolfo de Varnhagen, cuja obra tinha o objetivo de forjar uma identidade nacional, na qual o indígena teria pouca importância na formação do Brasil.

A produção historiográfica ao longo do século XIX possibilitou essa imagem de passado aos povos indígenas do Brasil. E, de alguma forma, eles sumiriam da história ou seriam incorporados à história nacional e civilizados ao longo dos processos republicanos. Para tanto, a produção historiográfica mediada por um movimento político promoveu um esquecimento sobre as populações indígenas contemporâneas, destinando a elas um lugar específico, como afirma Edson Silva ${ }^{17}$. Nesse sentido, boa parte dos livros didáticos deixa de lado a produção historiográfica recente sobre a temática indígena, que aponta o protagonismo indígena nos processos históricos ${ }^{18}$.

A produção acadêmica sobre o protagonismo indígena na história obteve maior destaque na década de 1990. Segundo Gersem Baniwa ${ }^{19}$, já na década de 1970 surgem de forma efetiva os movimentos organizados pelos indígenas e indigenistas reivindicando seus direitos, acesso à terra, educação, saúde e principalmente um lugar de destaque junto aos outros povos que foram excluídos de todos os âmbitos sociais por um discurso político oficial.

Para tanto, somente a partir da Constituição Federal de 1988 é que os assuntos relacionados ao reconhecimento dos povos indígenas enquanto indivíduos de direitos diferenciados toma uma dimensão de maior representatividade dentro dos parâmetros legais. E, ao longo desse novo momento político liberal republicano, foi se alimentando ainda mais a esperança dos povos nativos e a produção historiográfica para o reconhecimento deles como protagonistas na História.

Portanto, fazendo um pequeno estudo da participação indígena na História do Brasil nos livros didáticos, torna-se possível perceber as concepções

\footnotetext{
SANTOS, Maria Cristiane dos. Caminhos historiográficos na construção da história indígena. História Unisinos, Vol. 21, n 3, 2017, p. 347.

17 SILVA, Edson. Bárbaros, bons selvagens, heróis: imagens de índios no Brasil. CLIO - Série História do Nordeste, №.15.1994, p. 63.

18 OLIVEIRA, João Pacheco de. O nascimento do Brasil: revisão historiográfica. In: Anuário Antropológico. (online) 1/2010, postado online no dia 07 de Outubro 2015, consultado no dia 08 de Fevereiro de 2018. Disponível em <:http://aa.revues.org/758;DOI:10.4000/aa.758.> Acesso em: 04 set. 2018.

19 LUCIANO, Gersem dos Santos. $O$ índio brasileiro: $\mathrm{O}$ que você precisa saber sobre os povos indígenas no Brasil hoje, 1.ed. Brasília: Secad; LACED/Museu Nacional, 2006.
} 
que colocam os indígenas numa ótica preconceituosa relacionando-os a um passado distante, não abarcando os seus movimentos políticos pela afirmação cultural e reconhecimento de suas terras coletivas na modernidade.

Afirma Silva: "não é à toa, portanto, que os livros didáticos, de uma forma geral, mantenham a invisibilidade das sociedades indígenas e de tantos outros grupos sociais até os dias atuais" 20 . Os estudos atuais nas universidades e cursos de pós-graduação estão reconhecendo que é preciso reverter os problemas do ensino na educação básica sobre o protagonismo indígena que está relacionado, principalmente, ao modo como o livro didático expõe alguns conteúdos referentes à temática indígena, principalmente a partir da Lei $11.645 / 2008^{21}$.

\section{Os indígenas na República brasileira}

Em 1910, durante o governo de Nilo Peçanha, foi fundado o Serviço de Proteção aos Índios e Localização de Trabalhadores Nacionais, órgão subordinado ao Ministério da Agricultura, com a função de prestar assistência à população indígena brasileira $^{22}$.

Durante o período imperial, o desejo de incorporar os indígenas à sociedade que ia se formando no país foi de grande questão para os políticos. Imaginava-se que os povos indígenas, com o fim da escravidão, seriam os novos trabalhadores, e por fim, seria a vez de transformá-los em civilizados e súditos do rei, como predominou ao longo do período colonial. Durante todo o período de contato com os povos indígenas, seja na Colônia ou no Império, existiu a tentativa de compreender a melhor forma de anexação deles junto às comunidades de pequenos proprietários e trabalhadores rurais.

No início da Primeira República não foi diferente, a ideia de anexá-los por meio de uma legislação constitucional perdurou até meados da década de 1930. Os vieses do período colonial e imperial apontavam que os povos indígenas estavam por se extinguir por não se encontrarem como em 1500.

No Ceará, no relatório provincial de 1863, “o presidente da província José B. C. Figueiredo Júnior afirma não existirem índios vivendo na província

${ }_{20}$ SILVA, Giovani José da; SILVA, Vitor Ferreira da. Ensino de História e Mitologias indígenas: memórias e narrativas Kadiwéu (MS) e Wajãpi (AP). Revista Historiar, Sobral, Vol. 9. №.17, 2017, p. 16. Disponível em <http://www.uvanet.br/historiar/index.php/1/index> Acesso em: 04 set. 2018.

21 Idem.

22 GAGLIARDI, José Mauro. O indígena e a República. São Paulo: HUCITEC: Editora da Universidade de São Paulo: Secretaria de Estado da Cultua, 1987. (Estudos brasileiros, v. 25), p.19. 
cearense, nem como aldeados, nem muito menos como índios bravos"23. Houve uma tentativa de extinguir os indígenas por decretos ou leis constitucionais. Mas eles resistiram às investidas de invisibilização.

Estas questões, referentes à idealização da imagem do indígena no período colonial, foram e ainda hoje permanecem como um grande paradigma em relação a tais situações para o reconhecimento da história e cultura indígena na modernidade. Gagliardi afirma que "no século XIX, o trabalho de integração do indígena na sociedade dominante esteve sob a responsabilidade da Igreja Católica" ${ }^{24}$. Já durante a República é que se tem a ideia de transferir os povos indígenas para a tutela do Estado, com a criação do Serviço de Proteção aos Índios (SPI), em 1910.

Mas o diferencial dessa política foi a nova compreensão de que os povos indígenas não mereciam ser catequizados. Como de costume, a Igreja acreditava, mas devia-se segundo a nova legislação indigenista, reconhecer as diversidades culturais e proteção contra ataques reacionários do homem branco, grandes fazendeiros ou posseiros na região da Amazônia, Pará, São Paulo, Ceará e Minas Gerias, por exemplo. Eram regiões que estavam em crescente desenvolvimento econômico.

Tinha-se a conviç̧ão de que os povos indígenas não tinham a capacidade de reivindicar por meio de uma organização de grupos pela luta ao acesso às suas terras tradicionais. Segundo Giovane José da Silva e Anna Maria Ribeiro F.M da Costa:

\begin{abstract}
Vinculados aos preceitos do SPI, havia um 'projeto civilizatório' que previa para os povos indígenas um enquadramento evolucionista encontrado nos vieses do positivismo. Isso quer dizer que em relação à dimensão espacial das terras demarcadas, estas deveriam estar de acordo com o grau de contato dos índios com a sociedade não indígena, isto é, seriam demarcadas áreas maiores ou menores para o desenvolvimento da produção agrícola ${ }^{25}$.
\end{abstract}

A incorporação dos povos indígenas à sociedade republicana foi pensada por meio de uma nova perspectiva. A concepção era de que os povos indígenas seriam nacionalizados por meio do trabalho e vivência em meio ao desenvolvimento do capital republicano. Essa ação não reconhecia as diferenças socioculturais dos povos indígenas.

23 ANTUNES, Ticiana de Oliveira. 1863: o ano em que um decreto que nunca existiu extinguiu uma população indígena que nunca deixou de existir. AEDOS, vol. 4, n. 10, p. 8-27, Jan. / jul. 2012, p. 12.

24 Ibid., p. 20.

25 SILVA, Giovani José da Silva; COSTA, Anna Maria Ribeiro F. M. da. Histórias e culturas indígenas na Educação Básica.1.ed. Belo Horizonte: Autêntica Editora, 2018. (Coleção Práticas Docentes) p.105106. 
A constituição rompeu, portanto, com a tradição secular de integrá-los à sociedade brasileira, quando passou a reconhecer o direito dos indígenas de continuarem a ser índios. Os direitos coletivos, que englobam os aspectos territoriais, culturais e sociais, acham-se vinculados a uma série de ajustes para que possam se fazer presentes o cotidiano ${ }^{26}$.

Por fim, com a promulgação da Constituição Federal de 1988, têm-se expressivas vitórias em reconhecer a diversidade sociocultural dos povos indígenas no Brasil. Entretanto, são muitos problemas que ainda estamos por resolver. De um lado tem o reconhecimento dos povos indígenas, e de outro, existem frequentes confrontos destes com posseiros e grandes fazendeiros.

Ainda estamos por construir as bases sociais necessárias para a aceitação dos povos indígenas em seus costumes, crenças e tradições milenares que se auto afirmam como indígenas no século XXI. Foi um processo de luta e resistência de povos indígenas e indigenistas para uma nova concepção de políticas públicas voltadas para estes fins.

Com atividades de pesquisas e análises dos contextos sociais dos indígenas na atualidade é possível reconhecer que eles estão em nosso cotidiano em diferentes cidades do Brasil. E mais, eles estão utilizando os mais diferentes meios possíveis da política do homem branco para reinvindicações e melhorias para suas famílias por meio de assistências do Estado.

Portanto, propondo atividades de análises sobre os dados do IBGE é possível observar as diversidades de etnias existentes no país e línguas faladas pelas comunidades indígenas. Desta forma, é possível se desenvolver uma educação inclusiva e problematizadora sobre a situação dos indígenas no Brasil contemporâneo, e não somente lembrar do dia 19 de abril como um dia apenas para se pensar o indígena por meio de estereótipos com cocares e pinturas simplistas com tinta guache nos corpos dos alunos.

\section{Qual a imagem dos povos indígenas em instituições de ensino básico?}

Para a elaboração destas considerações, nos pontuamos a partir das respostas elaboradas por alunos e professores da área da disciplina de História, em conformidade com os objetivos do texto que segue com o objetivo de compreender um pouco sobre como os alunos estão apresentando os indígenas na História.

As respostas nos encaminharam para os objetivos exploratórios referentes ao ensino da temática indígena, segundo a efetivação da Lei 11.645 de

$26 \quad$ Id. Ibid., p. 109. 
2008. Por hora, aplicamos um questionário com dez questões relativas ao assunto pesquisado, mas em conformidade com as questões tratadas ao texto, apresentamos resultados sobre a questão que traduz todas as demais: O que você sabe sobre os povos indígenas?

Aplicamos metodologicamente para 50\% dos alunos do $8^{\circ}$ ano do Ensino Fundamental II da Escola Prefeito Walter Marinho. Devido a instituição contar com apenas duas turmas de $8^{\circ}$ ano. Segundo informações colhidas com funcionários da Secretaria de Educação de Hidrolândia, no ano de 2015, houve uma mudança no sistema de organização de ensino de Hidrolândia para as escolas da sede. A Escola de Ensino Fundamental Olcino Pereira de Souza passou a receber somente alunos dos últimos anos do ensino fundamental II. Nesse sentido, recebia somente alunos de $8^{\circ}$ e $9^{\circ}$, enquanto as demais escolas do município seriam responsáveis por receber os alunos das demais séries iniciais do ensino fundamental.

Por fim, aliando aos objetivos analíticos, procuramos um padrão entre as repostas dos alunos da turma de $8^{\circ}$ ano do turno da manhã que foram expostos no questionário. Para a pesquisa de campo participaram 23 alunos regularmente matriculados no Ensino Fundamental II.

Portanto, a escola no momento não conta com projetos pedagógicos voltados para o ensino de história e cultura indígena. Indagados, professores e gestores responderam: "Não, mas estamos trabalhando para construir um na mesma" ${ }^{27}$. Nota-se que existe um esforço para o ensino da temática indígena, mas ainda não se tem uma aplicação efetiva das questões voltadas para a efetivação da Lei 11.645 de 10 de março de 2008.

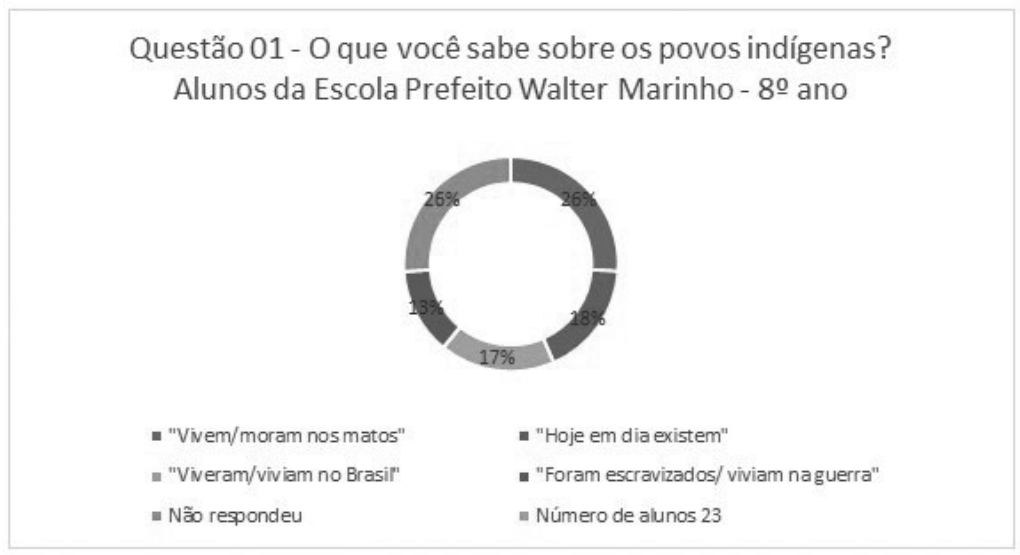

\footnotetext{
27 Resposta de um professor da disciplina de história a um questionário de pesquisa realizada por Paulo Ênio de Sousa Melo, tendo como objetivo principal; analisar como se desenvolve o ensino da temática indígena efetivado pela Lei $\mathbf{N}^{\circ} .11 .645$ de 10 de março de 2008 no componente curricular História em Hidrolândia-CE, no Ensino Fundamental II $8^{\circ}$ e $9^{\circ}$ anos nas escolas públicas do Município.
} 
Para tanto, nem mesmo o Estado ou Secretaria de Educação dão um suporte para essas questões voltadas ao ensino de história e cultura indígena. Pois, nesse sentido, a escola não tem recebido apoio ou qualquer treinamento do Estado para as questões relativas aos indígenas como protagonistas na História. As respostas dos alunos sobre uma questão feita a eles sobre os povos indígenas estão representadas no gráfico acima. O gráfico traz questões significativas sofre a ideia que se cristalizou sobre os povos indígenas ao longo da história do Brasil. E, entre estes, somando o número dos dados sobre "vivem/moram nos matos" e "viveram/viviam no Brasil", somam $43 \%$ dos alunos que cunharam em suas respostas termos com ambivalências em relação aos que se imagina do indígena na modernidade.

Ainda mesmo que se tenham alunos que compreendam que os índios existem, não demonstraram como eles se apresentam nas políticas modernas, lutando por participação e utilização das novas questões socioculturais. $\mathrm{E}$ ainda dentro destas questões, imagina-se que eles sempre praticavam a guerra como se fossem sanguinários, sem compreender as relações interétnicas e manutenção de comunicações entre os grupos étnicos, segundo Maria Regina Celestino de Almeida ${ }^{28}$.

Reiteramos que, para a construção das questões dadas entre aspas, foi o resultado analítico das repostas dos alunos que sempre convergiam para uma uniformização na organização de suas frases respostas. Ainda, conforme Giovani José da Silva e Anna Maria Ribeiro F.M. da Costa:

A caracterização das representações indígenas, calcada em imagens e adjetivos pejorativos, perpassou o período colonial, adentrou o monárquico e prevaleceu no republicano. Contextualizados historicamente por mais de cinco séculos, ainda hoje, os estereótipos e as estilizações do indígena colocam-no em um lugar desmerecido e menor na formação do povo brasileiro $^{29}$.

Desta forma, os livros didáticos de hoje ainda têm reforçado questões sobre imagens idílicas dos povos indígenas. Pela forma que os livros didáticos expõem, nos fazem compreender que os povos indígenas são aqueles que vivem em grandes florestas ou habitavam no Brasil. São poucas as vezes que apresentam os povos indígenas em profissões atuais, atuando e diversos meios modernos, como na política, nas escolas como professores, profissionais liberais e assalariados. Por isso que encontramos diversas concepções

28 ALMEIDA, Maria Regina Celestino de. Os índios na história do Brasil. Rio de Janeiro: Editora FGV, 2010.

29 SILVA, Giovani José da Silva; COSTA, Anna Maria Ribeiro F. M. da. Histórias e culturas indígenas na Educação Básica. 1. ed. Belo Horizonte: Autêntica Editora, 2018, p. 19 (Coleção Práticas Docentes). 
sobre os povos indígenas de que somente são aqueles que habitam em florestas ou habitavam no Brasil em 1500.

Nesse sentido, temos umas das questões referentes aos problemas de ensino de história e cultura indígena na educação básica. De um lado, o Estado ainda não desenvolveu mecanismos eficientes de treinamento para 0 ensino de história e cultura indígena, muitas vezes, os cursos de graduação não trabalham para estas perspectivas. E de outro, o trabalho do professor e da escola de educação básica, por meio de projetos, ainda têm falhado nessas questões voltadas ao ensino de história indígena. Não sabemos ao certo de onde vêm as principais responsabilidades. Mas reiteramos que é preciso que todas as instâncias educacionais estejam envolvidas para uma educação descolonizadora da imagem do indígena, para que não sejam sempre vistos como habitantes distantes da modernidade.

\section{Considerações finais}

Mesmo diante de tantas pesquisas existentes no século XXI sobre os povos indígenas, na História do Brasil ainda persistem questões referentes aos povos indígenas com representações simplistas e imagens estereotipadas. Ainda estamos por construir um ensino que transmita questões atualizadas referentes aos povos indígenas como protagonistas ao longo de todos os processos vivenciados na História de contato com os não indígenas. Ainda, como nos ensinou Giovani José da Silva, professor da Universidade Federal do Amapá (UNIFAP), em seus estudos sobre o ensino de história e cultura para educação básica, é possível transmitir um ensino para a descolonização da imagem do indígena do passado. Entretanto, para que esse ensino compreenda os povos indígenas com perspectivas de futuro, é preciso que na Educação Básica se busque meios para que se visualizem as diferenças socioculturais existentes no Brasil e suas novas posições sociais que se construíram ao longo do tempo. E, desta forma, é preciso que a sociedade brasileira tenha compromisso com as políticas públicas de inclusão social e, por conseguinte, desenvolva mais projetos pedagógicos que versem sobre o reconhecimento dos povos indígenas na história do Brasil, como proposto pela Lei 11.645 de 10 de março de 2008. 


\title{
11. Práticas de combate ao analfabetismo no Ceará
}

\author{
João Henrique Brito Lima ${ }^{1}$
}

\section{Introdução}

Este texto se propõe identificar as concepções do alfabetismo na visão das políticas desenvolvidas para o combate do analfabetismo entre os interesses os conflitos dos governantes e da população não alfabetizada no início da Primeira República. O Brasil possui grande extensão territorial, com ampla desigualdade social e elevado índice de pobreza. Isso afeta significativamente de diversas maneiras o combate ao analfabetismo e sua erradicação.

Estudar e entender o contexto histórico e econômico desse problema social, e propor soluções possíveis, contribuirá consideravelmente na formação de uma sociedade melhor. Neste trabalho, se discutirão algumas relações entre dinâmica demográfica e nível educacional da população a partir do |133 indicador da taxa de analfabetismo.

Posteriormente, verificar-se-ão também as ações do governo para melhorar esses índices. O estudo concluirá pelo Censo do IBGE, que indica que as altas taxas de analfabetismo observadas no país não estão relacionadas apenas à presença de analfabetos de gerações antigas na população, mas também devido à ineficiência do sistema educacional, por mais que esteja no processo de melhoramento de seus índices. $\mathrm{O}$ analfabetismo brasileiro é resultado tanto da precariedade do seu modelo educacional quanto na demora de ações de melhoria da alfabetização.

\section{As transformações políticas e sociais no início da Primeira}

\section{República cearense}

O desenvolvimento tecnológico e industrial esteve concentrado nos grandes centros urbanos, ocorrendo no Ceará, assim como no Brasil, por um impulso na economia com ações desenvolvidas pelas indústrias. Alguns reflexos dessa transformação nos anos iniciais da República no Ceará foi a reforma educacional implementada em 1922, por Lourenço Filho. Nesse pe- 
Nossa Gente,

Nossa História

o Ceará Republicano

ríodo, o Ceará registrava altos índices de analfabetismo, cerca de $80 \%$ da população.

Raquel da Silva Alves nos informa sobre o professor Lourenço Filho ao Ceará:

Relacionado aos procedimentos que o Estado deveria tomar para dinamizar o ensino podemos observar algumas referências às renovações administrativas do aparelho educacional cearense. Com esse objetivo, o presidente do Estado do Ceará, Justiniano de Serpa, solicitou a recomendação do governo de São Paulo de um profissional apto a desempenhar as medidas necessárias ao desenvolvimento do ensino público cearense. A argumentação utilizada pela administração pública, ao procurar o apoio do governo paulista, era pautada nos estudos modernos de ensino que já eram aplicados em São Paulo e, segundo o governo, reconhecidamente praticados vantajosamente. Essa atitude resultou na vinda do professor Lourenço Filho ao Ceará. A sua presença no estado cearense ocasionou a elaboração da Reforma Educacional de 1922. Lourenço Filho atuou como Diretor da Instrução Pública e foi considerado como figura relevante na administração do sistema público de ensino ${ }^{2}$.

Fica perceptível a contradição. De um lado temos um discurso produzido pelos governantes no combate ao analfabetismo para um progresso social com a construção de uma nação moderna e desenvolvida, mas de fato temos poucas práticas que viessem a viabilizar o desenvolvimento da alfabetização.

O início da República Brasileira tem a intenção de romper com o passado monárquico. Na tentativa de deixar de lado o atraso da produção monocultora, vem à tona novos ideais de progresso, tendo a industrialização como carro chefe do progresso liberal.

No século anterior, o ensino brasileiro beneficiava apenas os filhos dos grandes senhores de terra, ou seja, privilegiava o setor agrário. Com o desenvolvimento das atividades urbanas e, por conseguinte, das atividades industriais -, o trabalhador das fábricas começou a ganhar atenção: o processo de industrialização desencadeado a partir de 1930 passou a requerer maiores contingentes de mão de obra especializada ${ }^{3}$.

\footnotetext{
2 ALVES, Raquel da Silva. Mães da pátria: educadoras na terra da luz, o ensino primário no Ceará na década de 1920. 2009. 225 f. Dissertação (Mestrado em História) - Universidade Federal do Ceará, Departamento de História, Programa de Pós-Graduação em História Social, Fortaleza-CE, 2009, p. 64.

3 DEL PRIORE, Mary, 1952. Histórias da gente brasileira. Volume 3: República - Memórias (18891950) . Rio de Janeiro: LeYa, 2017, p. 490.
} 
No início da Primeira República, o Estado do Ceará ainda manteve a disputa pelo poder entre as oligarquias locais. Em suas alianças contavam com o uso de suas propriedades. O período foi conflituoso, pois a escolha dos representantes políticos foi marcada por inúmeras fraudes eleitorais, com muitas artimanhas do uso da máquina pública para permanecer no poder. Nogueira Accioly, com a oligarquia Acciolyna, foi o representante que passou mais tempo no controle do Estado do Ceará.

O historiador Raimundo Alves de Araújo apresenta o contexto familiar de Antonio Pinto Nogueira:

Nenhuma parentela soube se adaptar mais do que esta às mudanças acarretadas pela política de seu tempo. Deixaram os sertões secos de Santa Quitéria e estabeleceram-se em definitivo na capital da província do Ceará. Segundo Nertan Macedo, antes de se especializar no preenchimento dos mais altos postos públicos de poder provincial, o clã dos Pompeu se mistura a e se depura de muitas outras parentelas espalhadas por toda a região norte e oeste da província do Ceará no início do século XIX. Seus brotos se esparramavam desde os areais de Granja e Camocim, passando pelos armazéns de "secos e molhados" de Sobral, penetrando nos currais de gado dos sertões do Ipu, e terminam por se alojar nos gabinetes do parlamento provincial e geral, de modo tão absoluto que produziram cinco nomes de peso para o cenário político do Império e do início da República: Thomaz Pompeu de Souza Brasil (pai), Thomaz Pompeu de Souza Brasil (filho), Joaquim de Oliveira Catunda (sobrinho daquele), e, por adesão matrimonial, Antonio Pinto Nogueira Accioly (genro). Pelo alto grau de endogamia e exogamia para fins político-partidários, pela "bacharelização" de seus membros, e pela ocupação efetiva dos mais altos postos de poder no período, os Pompeu Brasil formam, sem dúvida, o mais bem sucedido "clã familiar" do Ceará deste período ${ }^{4}$.

\section{População não alfabetizada no início da Primeira República}

O início período Republicano é caracterizado como um momento de reconhecimento do analfabetismo no Brasil. O desenvolvimento das políticas liberais no Ceará República reproduziu os discursos de modernidade trazidos da Europa para o Brasil. Airton de Farias nos relata como se deu esse processo de ideias e debates que se desenvolveu:

ARAÚJO, Raimundo Alves de. Família e poder: a construção do Estado no noroeste cearense do século XIX (1830-1900). Dissertação. (Mestrado Acadêmico em História) - Universidade Estadual do Ceará - UECE. Centro de Humanidades. Fortaleza, 2011, p. 38. 
O rico debate de ideias ocorria, até certo ponto, independentemente dos demais movimentos que aconteciam no Brasil, ou seja, os modismos intelectuais eram muitas vezes importados diretamente da Europa, em especial da França. Trazia-se o que havia de mais progressista e moderno no Velho Mundo (positivismo, evolucionismo, darwinismo), com exceção do ideário marxista. Os intelectuais viam-se mesmo como arautos do conhecimento e indicadores do caminho da civilização e modernidade que o Ceará deveria seguir para alcançar o grau de desenvolvimento da Europa. Sentiam-se fascinados pela máquina, pela ciência, pelo racionalismo e tudo o mais que marcou o ocidente e o capitalismo no século XIX ${ }^{5}$.

Somente no início da Primeira República (1889 a 1930) foi que a elite intelectual brasileira passou a se preocupar com a instrução das camadas populares. A principal intenção foi levar o desenvolvimento da nação a um patamar letrado livre do analfabetismo. Nesse período, boa parte da população era analfabeta, como podemos perceber na tabela abaixo, através da pesquisa do IBGE, tendo a população $75 \%$ taxa de analfabetismo.

Tabela 1

\begin{tabular}{|c|c|c|c|c|}
\hline Ano & Alfabetizados & Analfabetos & $\begin{array}{c}\text { \% de analfabe- } \\
\text { tos sobre o total } \\
\text { da população }\end{array}$ & $\begin{array}{c}\text { \% de analfabetos } \\
\text { de 15 e mais anos } \\
\text { sobre o total do } \\
\text { mesmo grupo }\end{array}$ \\
\hline 1872 & 1.564 .481 & 8.365 .997 & 84,2 & - \\
\hline 1890 & 2.120 .559 & 12.213 .356 & 85,2 & - \\
\hline 1900 & 4.448 .681 & 12.989 .753 & 74,5 & 65,3 \\
\hline 1920 & 7.493 .357 & 23.142 .248 & 75,5 & 64,9 \\
\hline
\end{tabular}

Apud DAMASCENO (2010). Fonte: IBGE. Estatísticas Históricas do Brasil. Vol.03, 1986b.

A nova Constituição republicana de 1891 pôs fim ao sufrágio censitário, passando a incluir outras camadas da sociedade, mas ainda estavam excluídos os analfabetos. Um reflexo importante desse pensamento foi a alteração do conceito de cidadão apto a votar. Fato que anteriormente estava ligado à renda anual para se considerar eleitor. Demonstrando a preocupação dos governantes em expandir a bases de os eleitores como também a intenção de impulsionar e mobilizar os cidadãos para entrar no mundo dos letrados para

FARIAS, Airton de. História do Ceará. 7a. Ed. rev. e ampl. Fortaleza: Armazém da Cultura, 2015, p. 327. 
participação da vida política. Assim temos o recorte do texto da primeira Constituição republicana:

Art. 70. São eleitores os cidadãos maiores de 21 annos, que se alistarem na fórma da lei.

$\$ 1^{\circ}$ Não podem alistar-se eleitores para as eleições federaes, ou para as dos Estados:

$1^{\circ}$ Os mendigos;

$2^{\circ}$ Os analphabetos;

$3^{\circ}$ As praças de pré, exceptuando os alumnos das escolas militares de ensino superior;

$4^{\circ}$ Os religiosos de ordens monasticas. companhias, congregações, ou communidades de qualquer denominação, sujeitas a voto de obediencia, regra, ou estatuto, que importe a renuncia da liberdade individual ${ }^{6}$.

\section{Ações da sociedade civil ao combate do analfabetismo}

Diversos setores da sociedade se mobilizaram no combate ao analfabetismo. A Liga Nacional de Combate ao Analfabetismo teve uma representatividade que reunia setores da vida civil, como médicos, advogados e engenheiros.

Na mensagem dirigida à Assembleia Legislativa do Ceará em $1^{\circ}$ de julho de 1917, pelo Dr. João Thomé de Saboya e Silva ao Presidente do Estado do Ceará, podemos observar:

É digna de applausos e faz jus á gratidão publica a espontânea iniciativa particular e prol da instrucção primaria, com a instituição de ligas contra o analphabetismo e creação de escolas, quase a um tempo, em diversos pontos do Estado, onde a população menos favorecida da sorte, em horas que não prejudicam as do trabalho diário, recebe a precisa instrucção. Contam-se por centenas as pessoas que freqüentam essas escolas, sem as quaes, forçosamente, ficariam privadas da luzes da instrucção. Para esses desideratum, é-me grato declarar, muito constribuiu a imprensa e o meu Governo foi sempre solicito em lhe trazer o contingente que estava em sua alçada. Mandame a justiça que aqui consigne em destaque a ação meritória e decisiva de s.excia. revma. o sr. Dom Manuel da Silva Gomes, muito digno Arcebispo desta diocese, cujos esforços em prol da Liga contra o Analphabetismo excedem a medida de nossa espectativa ${ }^{7}$.

Disponível em: http://www2.camara.leg.br/legin/fed/consti/1824-1899/constituicao-35081-24 fevereiro-1891- 532699-publicacaooriginal-15017-pl.html. Acessado em 05 set. 2018.

7 Mensagem dirigida à Assembleia Legislativa do Ceará em $1^{\circ}$ de julho de 1917, pelo Dr. João Thomé de Saboya e Silva, Presidente do Estado. Fortaleza, 1917 p.18 Apud DAMASCENO, A. D. Analfabetismo 
Um dos problemas trazidos pelo discurso de erradicação do analfabetismo foi a divulgação da falta de alfabetização como uma doença, a praga, que impedia o Brasil de se desenvolver. Essa concepção de alfabetismo fez com que passasse um preconceito às pessoas analfabetas. Passaram a ser percebidas como pessoas incapazes de decidir e pensar e agir por não terem domínio da leitura e da escrita.

Os Estados passaram a adotar suas composições. O estado do Ceará teve destaque com a criação da Liga Cearense de Combate Analfabetismo. Assim nos informa Raquel da Silva Alves sobre sua composição.

[...] a campanha desenvolvida por intelectuais cearenses, na fundação em 1919, da Liga Cearense Contra o Analfabetismo em prol da superação da ignorância pela instrução do povo. A Liga desenvolvia atividades direcionadas aos trabalhadores. Escolas noturnas foram criadas por esse grupo direcionadas a esse público. Embora não tenha sido possível destacar a atuação desse grupo na década de 1920, alguns dos intelectuais que estavam envolvidos nesse projeto, criaram nesse período a Sociedade Cearense de Educação, composta por: Monsenhor Tabosa Braga, drs. João Hippolyto de Azevedo e Sá, Pimentel Júnior, José Sombra, Sylla Ribeiro, Heriblado Costa, Andrade Furtado e José Martins Rodrigues, padre Rodolpho F. da Cunha, d. Julia Vasconcellos, Clovis Monteiro, Sales Campos, Alcides Montano e Rosendo Ribeiro acabam de organizar a "Sociedade Cearense de Educação", que terá como seu presidente o dr. Menezes Pimentel, a qual visa, nobremente, a defesa e propagação da educação popular, desenvolvimento da cultura pedagogica, amparo às instituições auxilliadoras do ensino como caixas escolares, museus, bibliothecas, escotismo, apoio ao professorado etc ${ }^{8}$.

A criação da Liga Nacional de Combate ao Analfabetismo ocorreu por ocasião do primeiro Centenário da Independência, em 1922. As ações no Estado do Ceará tiveram como principais características a implementação de turmas de alfabetização com apoio do governo do estado. Embora esse movimento tenha uma data anterior no Estado do Ceará, não se tem uma data precisa.

Sua pretensão era erradicar o analfabetismo no Estado do Ceará, porém, foi pouco expressivo seu desempenho, pois os relatos demonstram que conseguiu diminuir apenas $5 \%$ no índice de analfabetos. Ao passo que buscava acabar com o analfabetismo, propagava a ideia do analfabeto como um pro- 
blema social, que impede o crescimento do país. Aumentava-se, dessa forma, o preconceito para com as pessoas analfabetas, pois a liga não dispunha em discutir as reais causas dos altos índices de analfabetismo. Apenas julgava e condenava os analfabetos, sendo criticado por alguns intelectuais da sua composição de papel elitista. Contava com grandes nomes da elite cearense.

As medidas adotadas na Educação para combater o analfabetismo aconteceram principalmente nas classes noturnas, com a participação de vários setores da sociedade, dentre eles a Igreja, com os Círculos Operários Católicos, juntamente como a Liga Nacional de combate ao analfabetismo.

Assim nos relata o historiador Airton Farias sobre o Círculo Operário São José:

[...] a proposta da Legião parece-nos bastante diferente dos fins do Círculo São José, mais preocupado em orientar moral e espiritualmente os trabalhadores. A Legião Cearense do Trabalho, enquanto movimento social, propôs estabelecer uma mediação entre classe operária e Estado, o que lhe conferia uma feição mais "partidária" e um caráter mais "combativo" do que os Círculos Operários. Uma das diferenças mais marcantes entre os Círculos Operários e a LCT refere-se aos movimentos grevistas. A Legião Cearense apoiava as greves [...] Contudo, na visão circulista, os movimentos grevistas, considerados como uma negação ao trabalho, eram expressamente combatidos e associados à desordem e entendidos como uma ameaça à paz social ${ }^{9}$.

Tendo como base o ensino na educação patriótica, da moral e cívica, a educação era pensada de forma quantitativa. Apenas números eram interessantes para a expansão da Indústria, que se fazia necessário conhecimento da leitura.

Encontramos em textos desse período o termo "povo civilizado" e, a partir disso podemos observar como a idéia de civilidade foi apresentada como discurso de pátria; para o Brasil tornar-se um país do futuro precisaria civilizar o povo, estender a noção de civilização a todo o país: "A instrucção isolada da verdadeira educação moral não destróe o egoísmo, não ensina a disciplinar a vontade, concorre a tornar o indivíduo mais apto para o crime"10.

A intenção da Igreja Católica era de, através do ensino e letramento, desenvolver o ensino moral cristão na perspectiva de afastar os operários das 
ideias anarquistas, difundidas pelos sindicatos e partidos comunistas. De acordo com Airton de Farias:

\begin{abstract}
Os sindicalistas de tendência libertária acreditavam que a apatia do movimento sindical devia-se ao analfabetismo e à ignorância do meio operário - desejavam não apenas que os trabalhadores dominassem os rudimentos de escrita e leitura, mas que tivessem condições de entender como eram explorados dentro do capitalismo e como o socialismo lhes permitiria a emancipação social. Assim, é constante a preocupação com a fundação de escolas e grupos de leitura e debates, afora a realização de palestras e conferências, difundindo-se o pensamento libertário ${ }^{11}$.
\end{abstract}

\title{
A população não alfabetizada no contesto politico social
}

O processo inicial de letramento era privilégio de poucos no ensino primário. A classe política denunciava o analfabetismo como um grande entrave ao crescimento social. No período, acreditava-se que não poderia se chegar à independência econômica e intelectual do Brasil, sendo este ainda

140 dominado pela ignorância. Através da análise político social é possível perceber no discurso político dos governantes outras intenções, como a de ampliar o contingente de eleitores.

A baixa frequência escolar levou a classe política a culpar a população por falta de interesse em participar do processo de letramento, afirmando que era vontade sua permanecer na ignorância. Mas através da pesquisa, outras causas foram apontadas, como a falta de infraestrutura e formação dos educadores, um dos principais fatos geradores do desinteresse na participação das turmas de alfabetização.

No período inicial da República, as expectativas do novo impulso industrial não abarcavam os saberes trazidos pela população, que em grande maioria ainda era ruralizada. O analfabetismo colocava o Brasil em uma posição de desprestígio no cenário mundial, visto que os países ditos modernos já haviam universalizado o acesso à educação.

O debate político se dividiu entre os que pretendiam incentivar o letramento da população para aumentar a massa de eleitores e os que defendiam o processo de educação de qualidade para formação cidadã.

A postura de erradicação governamental fez com que se julgasse os não alfabetizados como pessoas incapazes, a esses não sendo possível a partici-

$\overline{11}$ FARIAS, Airton de, Op. cit., p. 630. 
pação na vida política. Temos relatos de políticas pensadas pelo Governo do Estado do Ceará com a intenção de aumentar a frequência dos alunos na escola. Foi planejada a criação de um imposto que seria cobrado dos pais que não levassem os filhos à escola. Nesse momento, a intenção do Estado de transferir a responsabilidade da participação do ensino para a família.

Conforme o relato trazido por Raquel da Silva Alves, temos:

Dessa forma, o que era justificado como desinteresse do povo pela educação era fundamentado pelo descrédito no ensino e no governo, principalmente porque o Estado falhava em não cumprir o que foi estabelecido no Título II do Regulamento de Ensino de 1922:

Art. $3^{\circ}$ - São obrigadas à freqüência escolar gratuita as crianças analfabetas de 7 a 12 anos. Esse artigo era garantido pela multa de $10 \$$ a $50 \$$ que os pais deveriam pagar caso não o cumprissem, o que viria a resultar na prisão de 8 a 15 dias $^{12}$.

Diversas iniciativas dos governantes e da imprensa para mobilizar a população foram realizadas com o intuito de mostrar a necessidade de se combater a ignorância e adquirir autonomia através do voto na escolha dos representantes. Pouco resultado foi obtido com as campanhas. Ainda continuamos com altos índices de analfabetismo. Imaginar de maneira dicotômica um problema é fugir de uma problematização da conjuntura políticosocial.

A campanha empreendida pela Liga encontrou apoio nos diversos cantos do Brasil, sobretudo através da atuação de Ligas estaduais e municipais. A análise destas ações evidencia que as Ligas atuavam em uma dupla direção ao coordenar ações de combate ao analfabetismo que incentivavam o engajamento e a mobilização da sociedade em favor da instrução e, ao mesmo tempo, chamar o Estado a atuar, exigindo sua intervenção em questões como a decretação da obrigatoriedade do Ensino Primário. Percebe-se que, entre memórias e esquecimentos, as Ligas fundadas durante a década de 1910 têm muito a nos revelar acerca da mobilização social neste país, demonstrando que a Primeira República representa um momento estratégico na História do Brasil ${ }^{13}$.

Boa parte da população pobre não alfabetizada não tinha interesse pela leitura. Isso porque não se fazia necessária para o trabalho que desenvol-

13 NOFUENTES, Vanessa Carvalho. Um desafio do tamanho da Nação: a campanha da Liga Brasileira contra o analfabetismo (1915-1922), Dissertação de Mestrado em História, Rio de Janeiro, PUC, 2008. 
viam. Este era um fato de desestímulo associado à precária estrutura encontrada nos centros educacionais. Somado à formação de professores, que tinha como metodologia pensada no ensino das primeiras letras, o método era desenvolvido por meio de técnicas repetitivas para desenvolvimento da memorização.

Hoje é possível entender o porquê da falta de interesse, pois a preocupação primária era a subsistência, na atividade do homem sertanejo em sua vida dura. A produção do alimento diário em um solo árido, com poucas chuvas, era uma das questões que levavam desinteresse pelas letras iniciais. Como ocorreu na seca de 1915, que levou várias pessoas a se deslocarem no interior do Estado para capital em busca de sobrevivência. Os flagelados da seca, que foram cercados pela medida higienista. Posteriormente, justificado por medidas sanitárias de combate a doenças.

Secas, por si sós, fazem aumentar a tensão social e desgastam a imagem dos governantes. Quando, porém, estes omitem-se quase completamente, como no caso de Accioly naquelas estiagens, a insatisfação atinge patamares levados. O oligarca transferiu totalmente a responsabilidade do combate às secas para o governo federal. Accioly chegou ao cúmulo de tentar proibir a emigração dos retirantes interioranos (os quais não paravam de chegar a Fortaleza) para outros estados, temendo perder eleitores e mão de obra barata. Evidentemente tal medida não foi cumprida, pois o censo de 1900 revelou que, sendo a população do Ceará cerca de 850 mil habitantes, houve uma imigração para os estados do norte de 27 mil pessoas e duas mil para o centro-sul ${ }^{14}$.

\section{As politicas públicas implementadas no combate ao analfabetismo no estado do Ceará}

Em 1915 houve a preocupação do governo do Ceará em criar um Regimento que pudesse organizar a educação do estado. Nesse ano foi criado um que trazia mudanças na concepção de educação, trazendo agora a educação como interesse em despertar o conhecimento através da simulação de conteúdos práticos para ajudar no dia a dia.

O Regimento trazia a simplificação do processo de ensino-aprendizagem, não apenas no sentido de desburocratizar a entrada de alunos, mas passando a iniciar as aulas apenas com a mera apresentação do aluno ao professor. A escolha de conteúdo a ser indicada pelo próprio professor era feita sem

${ }_{14}$ Farias, Airton de, Op. cit., p. 490. 
que houvesse currículo ou alguma diretriz curricular. A ideia era justamente o letramento com base na significação dos conteúdos. Foram apresentados inúmeros cursos práticos relacionados a atividades domésticas para as meninas.

O processo de alfabetização com base nas letras regimentais não se mostrou eficiente, pois ainda se mantiveram altos os níveis de evasão dentro das conjunturas das transformações na educação. Temos, em 1920, a formação de novos profissionais com base no ensino com a preocupação não apenas de ensinar a ler e escrever, passando para uma educação integral na formação do cidadão. Esse movimento ficou conhecido como "otimismo pedagógico".

Então durante o governo de Justiniano de Serpa foram implementadas mudanças educacionais capitaneadas por Lourenço Filho, que pretendiam modificar o sistema educacional tendo a escola primária e a escola normal suas divisões organizadas na estrutura educacional. Professores passaram a ser formados através de princípios da Nova Escola ${ }^{15}$. A aquisição de novos materiais didáticos buscou amenizar o analfabetismo. Adotou-se no Ceará a prioridade para alunos com base da idade escolar de 7 a 12 anos.

O projeto político democrático utilizava o ideário da Escola Nova como projeto pedagógico nacional e nele vamos encontrar alguns intelectuais envolvidos no chamado "entusiasmo pedagógico", que buscava erradicar o analfabetismo do cenário 143 nacional. Dentre eles, um dos pontos de evidência é o conceito de trabalho, diante da profissionalização do magistério e da inserção da mulher no serviço público, a partir da construção de uma identidade pautada nas qualidades femininas apropriadas ao ensino primário ${ }^{16}$.

Lourenço Filho foi responsável por implementar as mudanças mais significativas para o período. Em todas as atividades desenvolvidas, realizou o recenseamento das crianças com idade escolar. Criou cursos de férias de formação de professores para que pudessem participar da reforma do currículo e das diretrizes educacionais. Criou o Curso Normal e contava com o apoio irrestrito do Governador Justiniano de Serpa. Só após a morte do governador seu projeto reformista entrou em declínio, em 1934, com seu retorno a São Paulo, tendo o ensino primário normal o enfraquecimento dos ânimos.

15 A Escola Nova chegou ao Brasil na década de 1920 com as reformas do Ensino de vários Estados brasileiros. O movimento defendia uma escola pública universal e gratuita proporcionada a todos, e todos deveriam receber o mesmo tipo de educação. Pretendiam com o movimento criar uma igualdade de oportunidades.

16 ALVES, Raquel da Silva, Op. cit., p. 11. 



\title{
12. A Educação na República
}

\author{
Natanael Alves Lopes ${ }^{1}$
}

\section{Introdução}

Sabe-se que nos dias atuais a educação brasileira é bastante precária, tendo inúmeros problemas, como a indisciplina a desvalorização do professor. $\mathrm{O}$ desinteresse dos alunos, porém, nem sempre foi assim. Há alguns anos, a nossa educação era de melhor qualidade, os professores eram respeitados e, mais do que isso, eram temidos pelos alunos e até mesmo apoiados pelos pais dos estudantes. Era um modelo de educação bem rígido e bem intolerante quando o assunto é indisciplina e falta de interesse em aprender.

Sabe-se que na década de 1970 a escola que tinha referência em educação de ensino médio do Ceará era uma escola pública conhecida como Liceu do Ceará. Nos dias de hoje, causa-se até espanto ao sabermos que esse tipo de escola era considerada de bom desempenho. Mas se esta escola do estado era tão boa nessa época, isso também significava que ela era destinada apenas às classes mais abastadas da sociedade. Aos jovens das classes menos favorecidas, restava ingressar no campo de trabalho mais cedo.

Nessa época, de acordo com alguns estudiosos, os professores eram valorizados como figuras importantes na sociedade e na construção de uma nação próspera; a imagem que a sociedade tinha do professor era completamente diferente da de hoje.

A década de 1990 foi o divisor de águas na educação brasileira. Os professores já não são tão autoritários como antes, porém a indisciplina é corrigida. Os pais ainda estimulavam seus filhos a estudarem e a terem com os professores uma dose de respeito. A indisciplina ainda era corrigida, mas não tão severamente como antes. Nesta década, a indisciplina era ainda um tanto diferente da dos dias atuais.

Obviamente que existem outros fatores que levaram a educação na República à deterioração, como a maior liberdade que os alunos têm hoje em dia, a ignorância dos pais com relação à importância da educação, e o ataque ao método tradicional, afirmando-se que ele não é eficiente atualmente, e que para ajudar os alunos a se interessarem pelos conteúdos será necessário criar novas estratégias para prender sua atenção. Porém, o método tradicional funcionou perfeitamente por vários séculos. Portanto, se a educação na 
República declinou, o causador desse problema não é o método, e sim o fato de que os professores perderam a autoridade na sala de aula.

$\mathrm{O}$ artigo aqui apresentado tem a intenção de informar ao leitor os motivos do declínio da educação brasileira. Sabe-se que no nosso país houve um tempo em que os professores eram respeitados e a indisciplina era severamente corrigida. Apesar de naquela época muitas escolas públicas terem uma estrutura frágil, havia um excelente aprendizado e a educação nem sequer era obrigatória. O governo não auxiliava os estudantes com transporte, nos dias atuais as escolas têm computadores, data show entre outras tecnologias, transporte responsáveis pela condução dos alunos e as escolas têm uma melhor estrutura.

Nos dias atuais, a maioria dos estudantes não tem noção da importância do estudo e os professores são desrespeitados em sala de aula, a indisciplina predomina em muitas salas de aula. Neste artigo, serão abordados os caminhos que a educação brasileira percorreu para que os estudantes, mesmo rodeados de aparatos tecnológicos e tendo as melhores chances de serem bem-sucedidos e de serem bons cidadãos, jogam todas as oportunidades que lhes são concedidas pela janela.

Ser professor nos dias atuais no Brasil é um desafio. Já conheci alguns filhos de professores que não desejam seguir a carreira dos pais porque profes146 sor é desvalorizado. Eu mesmo, quando dizia que queria fazer História para ser professor, algumas pessoas me desestimulavam porque diziam, segundo eles, que professores perdem muito tempo com alunos que não querem aprender. Se o leitor achou isso uma situação difícil de lidar, então prepare-se pelo que eu vou dizer. Até mesmo outros professores diziam que não era boa ideia eu seguir a carreira da docência.

O problema da educação no Brasil é mais sério do que imaginamos, a sociedade não valoriza os professores, e também muitos deles não valorizam a própria profissão. Desde já fica aqui a reflexão: se nem os próprios professores valorizam a profissão que desejaram seguir, como podem esperar que os outros valorizem? Portanto, se os professores querem ver sua profissão reconhecida como importante, têm de começar por eles próprios.

Ao invés da educação progredir, ela parece estar regredindo. Com uma educação de má qualidade, nossa sociedade estará fadada ao fracasso, não à toa, os brasileiros ficam na última colocação nos testes internacionais.

\section{Educação autoritária no Brasil}

Dizer que os professores eram respeitados nas salas de aula no passado no Brasil é eufemismo, é mais correto dizer que os professores eram temidos. 
Naquela época, o modelo de educação era uma didática rígida com o uso da palmatória. O professor passava o conteúdo e depois havia as perguntas. Caso o aluno não soubesse ou errasse, eram aplicados castigos físicos. Ainda há relatos de que os alunos que sabiam as perguntas feitas pelo professor aplicavam a palmatória nos que não sabiam. A palmatória era um objeto com cabo e esfera de madeira, o castigo físico aplicado no aluno era conhecido como "bolo". De acordo com Raimundo Soares, contemporâneo da palmatória, "naquele tempo os alunos estudavam muito com medo da palmatória, quando o aluno levava bolo do outro ele estudava muito a cartilha do ABC para descontar no outro que deu bolo nele". Ainda sobre a palmatória, Raimundo Soares nos dá mais detalhes em como era aplicada: "A professora mostrava as letras na cartilha aos alunos e ela perguntava 'que letra é essa'? $\mathrm{O}$ aluno que não soubesse, ela perguntava a outro. Se ele soubesse a letra, o que acertou dava o bolo nele"2.

A indisciplina no período anterior a Republica era bem diferente da de hoje, sem contar que eram raros os alunos indisciplinados. Conta-se que no Colégio da Providência, em Reriutaba, na década de 1970, quando os alunos começavam a conversar na hora das explicações, eram repreendidos, se insistissem nas conversas, o diretor era chamado, os alunos poderiam até ser suspensos por dois dias ou até mesmo uma semana, dependendo da situação, os pais da criança ou do adolescente eram chamados à escola e informados sobre a situação.

Minha avó, Jovina Alves de Sousa, já falecida, que na década de 1920 estudou na casa de uma senhora que ensinava as crianças da região de Cabaceira, zona rural da Reriutaba, contava o seguinte relato:

O marido da professora tinha acabado de sair e pediu para ela ficar de olho na carne de porco que estava sendo assada, ela esqueceu, a gente estava sentido um cheiro de queimado eu falei com a minha amiga que era a carne de porco que estava queimando, a professora viu a gente conversando e perguntou em um tom grosseiro: o que é que estão vendo? Aí a gente se calou ${ }^{3}$.

Outro relato que minha avó conta de seus tempos de estudante e que nos ajuda a entender como eram tratados simples atos que naquela época eram vistos como indisciplina: "Passou o marido da professora no terreiro, quando derrubou o chapéu a gente começou a rir, a professora disse: "Que é que estão vendo"? Com um tom de autoridade, aí a gente se calou”4.

\footnotetext{
Raimundo Soares, pedreiro, 64 anos. Entrevista realizada pelo autor em 12 de outubro de 2018. Varjota-CE.

Jovina Alves de Sousa. Relatos guardados em minha memória.
}

4 Idem. 
As crianças da zona rural percorriam longas distâncias a pé até a cidade para conseguir estudar. O governo não oferecia transporte, e nem ao menos dava muitos recursos financeiros para as escolas, pelo menos nas cidades do interior. Naquele tempo, nem todos os professores tinham formação acadêmica, para se dar aula no primário, era preciso no mínimo ter pelo menos até a $4^{\mathrm{a}}$ série. Muitas pessoas que tinham pelo menos esse grau de ensino montavam sua "escolinha" na própria casa, arrumavam uns bancos, informavam uns vizinhos e estava feita a "creche".

Existem relatos de que o período anterior à redemocratização os professores só explicavam o conteúdo uma vez. Quem não tivesse prestado atenção perdia a chance de aprender, porque o professor não voltava a repetir as explicações, ao que tudo indica, o único direito que o aluno tinha era de ouvir e aprender, nada de questionar.

Minha professora da $4^{\text {a }}$ série, quando ensinava as operações matemáticas para nós e depois fazia algumas perguntas e nós contávamos nos dedos para ajudar a acertar as respostas, nos dizia que quando ela estudava a matemática na escola, no tempo dela, a professora não permitia que ela contasse nos dedos ou não ganharia a nota.

Esse tipo de educação é um modelo que exige muito dos alunos, e os ${ }_{148}$ professores parecem mais autoridades dentro das salas de aula do que um simples mediador entre o aluno e o conhecimento, como se propõe nos dias atuais. Esses métodos, se comparados com os de hoje, parecem ser bem insensíveis. Para o leitor ter noção de como na década de 1980 a indisciplina era corrigida, aqui contaremos um caso:

Em plena aula, um aluno xingou um de seus colegas por ser homossexual. O estudante ofendido reclamou ao professor do insulto. No mesmo instante o professor se dirigiu ao aluno indisciplinado e lhe disse: "Ei você, para fora!" e o jovem teve de se retirar da sala. O jovem homossexual teria dito "vai com a pomba do divino". O professor se dirigiu a este também e lhe disse: "você também para fora!" e aquele jovem também teve de se retirar da sala.

Outro caso semelhante a este primeiro é narrado. Conta-se que uns quatro garotos estavam brincando na hora do recreio quando aqueles tiveram descaso com o banco da escola. $\mathrm{O}$ diretor, que era um ex-padre mandou chamar aqueles garotos e disse que iria expulsá-los por "descaso com o patrimônio público". Um dos garotos pranteava, porque sabia que quando chegasse em casa seu pai lhe daria muita surra. Outro daqueles garotos disse: "Diretor, me expulse, mas não expulse ele (se referindo ao garoto que chorava). Meu pai vai me matricular ano que vem, mas, o pai dele vai matar ele quando chegar em casa”. Então aquele diretor disse: vendo por esse lado, você está certo, então não vou expulsar vocês, mas se eu souber que vocês 
fizerem alguma outra bagunça, não vou querer nem ouvir vocês, irão logo para a expulsão.

Se comparados com os dias atuais, os professores e diretores daquela época eram um tanto desumanos, apenas davam o conteúdo e os alunos que se virassem para aprender. Era uma educação de modelo bem individualista, ouvir e entender o aluno não era com eles, qualquer ato de indisciplina, por menor que fosse, era severamente rechaçado em nome da moral e da boa conduta para se formar bons cidadãos.

É preciso lembrar também que naquele tempo as crianças e jovens tinham estímulos dos pais para frequentarem a escola, a educação naquela época não era obrigatória, portanto, os pais que matriculavam seus filhos na escola, faziam isso não por obrigação, e sim porque realmente queriam um futuro promissor para seus filhos.

Vale ressaltar que esse modelo de educação, como Molde, traz vantagens como os conceitos de esforço, autodomínio, responsabilidade e disciplina, porém, esses métodos, embora eficientes no que diz respeito ao ensino, são inadmissíveis nos dias de hoje, precisam de um método que além de eficaz seja humano, e não despótico.

\section{Década de 1990}

A década de 1990 é o marco entre o ensino de viés autoritário e a educação atual, com seus grandes problemas, onde o professor não é valorizado e não se tem o mínimo de respeito pelos profissionais da educação. A indisciplina tornou-se um dos principais desafios dos professores na atualidade, e com isso nosso país declinou nos processos de aprendizagem.

De acordo com um relato de um indivíduo, que foi aluno na década de 1990 no Ensino Fundamental, havia sim doses maiores de indisciplina do que no período da educação de modelo molde, porém, ainda era uma indisciplina bem longe da dos dias atuais, era uma indisciplina de insultar e apelidar uns aos outros, não de desrespeitar o professor, alguns levavam esses tipos de gozação na brincadeira, outros não.

De acordo com ele, o respeito que os estudantes tinham pelos pais, tinham pelos professores, e "as famílias na década de 90 eram mais estruturadas não no sentido econômico, mas no sentido familiar, eram menos fragmentadas" ${ }^{\prime}$.

Naquela época, os pais repassavam aos filhos a ideia de que a escola era uma extensão do lar, ou uma segunda casa, o estudo era visto como algo de 
vital importância para a sociedade naquele momento, por isso se tinha respeito pela figura dos professores.

O estudante de pedagogia relata ainda, que seus pais o incentivavam a estudar, se ele fosse à escola pela manhã, trabalhava à tarde ajudando seu pai. No próximo ano, se estudasse à tarde ajudava seu pai pela manhã. Por esses relatos, nota-se que estudar na década de 1990 era visto como um privilégio, e não como um enfado.

De acordo com minha irmã, a professora de Letras Inglês Gleiciane Lopes, que estudou no primário na década de 1990 numa escola particular, os alunos daquela época eram mais comportados. Assim como o estudante de pedagogia relatou que alunos insultavam uns aos outros e não desrespeitavam os professores, "não havia muitas conversas na hora da explicação", diz a professora de inglês. Ela diz ainda que ela era uma das alunas mais comportadas da classe, isso porque seus pais, desde cedo, lhe diziam que "a escola é um lugar para estudar", "por isso era comportada". Por esta passagem, percebemos a importância dos pais na formação educacional e escolar das crianças, como também na valorização dos professores ${ }^{6}$.

Posso dizer que eu ainda acompanhei esse tempo onde se exigia disciplina dos alunos nas escolas. Em 1999 eu estudava na alfabetização e um dia eu entreguei a tarefa de casa respondida de caneta e a professora perguntou: "Natanael Eu mandei você fazer de caneta"? Naquele instante comecei a chorar e, por coincidência, alguns outros colegas tinham feito alguma coisa de errado e também choraram (antes até de mim) pela repreensão da professora. Naquele dia, todos nós que fizemos algo de errado ficamos sem recreio, parecia até que a gente tinha combinado de fazer algo de errado para ficar dentro da sala na hora do recreio.

Existem relatos de alunos do Ensino Médio na década de 1990 que até mesmo chamaram palavrões com professores, mas ainda nessa época os professores tinham maiores chances de corrigir tais atos de indisciplina. Podemos dizer que ainda restava uma parcela de autoridade e respeito aos professores.

\section{Dias atuais, a crise na educação brasileira}

Quando eu fiz estágio no Ensino Fundamental, consegui ver de perto os graves problemas que afetam a educação brasileira. Primeiro fui ao $9^{\circ} \mathrm{A}$ e

Gleiciane Lopes, 30 anos, professora. Entrevista realizada pelo autor, em 12 de outubro de 2018. Varjota-CE. 
pude ver que boa parte daqueles alunos era bem participativa. A professora perguntava o que eles tinham visto na aula passada e muitos deles lembravam. É bem verdade que havia também alguns que dormiam, algumas conversas e a professora teve de chamar a atenção deles. Mas esses casos eram raros naquela classe, aquela sala era o sonho de qualquer professor, eu diria, era uma turma mais comportada e melhor disciplinada.

Já quando eu fui para o $9^{\circ} \mathrm{B}$, as coisas mudaram completamente e a maioria dos alunos conversava, faziam piadas com o conteúdo da aula, não prestavam atenção nas explicações. Eu via a professora perdendo muito tempo chamando a atenção dos alunos, havia uma quantidade mínima naquela sala que ainda fazia algumas perguntas à professora, mas no geral, havia uma desconcentração enorme na hora das explicações, a maioria daqueles alunos não conseguia absolver o conhecimento histórico que a professora lhes oferecia.

Segundo eu soube, existem escolas em nosso país que colocam os alunos considerados melhores em uma sala e os considerados piores em outra. Essa explicação nos mostra como uma das salas pode ser considerada melhor e outra a pior. Eu passei em algumas outras salas de aula e havia aquelas que eram medianas, isto é, nem considerada tão ruim nem tão boa, pude observar que muitos daqueles estudantes não dão muita importância aos estudos e a figura do professor não era bem respeitada como deveria ser, as aulas eram atrapalhadas pelos estudantes diversas vezes, que faziam diversos tipos de barulhos, e muitos desses alunos eram pouco atentos às aulas.

Muitas escolas hoje têm computadores, salas de vídeo, se passa filmes para os alunos, têm transporte, se usa data show, entre outras tecnologias para melhor aprendizado dos alunos, existem livros didáticos para todas as escolas. Como é possível com tantas novidades e inovações na educação as coisas irem tão mal assim?

As causas pelas quais a nossa educação tem declinado tanto são diversas. Se até pelo menos a década de 1990 os jovens respeitavam seus pais, nos dias atuais isso está mais difícil. Lembremo-nos da frase do estudante de pedagogia, que na década de 1990 "havia respeito pelos professores porque havia respeito pelos pais". Parafraseando um amigo meu, que disse que não se casaria com uma mulher que mente para a mãe porque ela também vai mentir para o marido, se uma mulher mente até para a própria mãe irá ser verdadeira para alguém de fora? Se um jovem não tem respeito pelos próprios pais, terá respeito pelos seus professores?

Uma professora minha da faculdade mencionou que um dos motivos da indisciplina é o fato dos pais darem muitas liberdades aos seus filhos. Quan- 
do um uma criança ou adolescente quer uma coisa, mesmo que os pais tenham dificuldades de arcar com o desejo de seus filhos, muitos desses pais acabam cedendo, assim, essas pessoas vão crescendo não conhecendo a palavra "limite".

O programa do Governo Federal Bolsa Família foi importante, pois atendeu a diversas famílias carentes, mas com o passar do tempo, esse programa pode ter se tornado um problema para a educação, pois muitos dos pais não estariam mais preocupados com a educação de seus filhos. A educação nos dias atuais perdeu um dos seus principais pilares, o incentivo dos pais para $\mathrm{o}$ estudo, esse fator, que como já foi citado aqui, foi fundamental para que haja uma melhor disciplina dos estudantes ${ }^{7}$.

Nos dias de hoje, se diz que o tempo da adolescência é o tempo da rebeldia, eu mesmo já ouvi dizer quando eu tinha meus doze anos, na época que eu estava prestes a me tornar um adolescente, que essa era uma fase difícil, mas eu mesmo nunca cometi qualquer ato de rebeldia e nunca ousei a desafiar meus pais.

Hoje em dia há uma vitimização dos estudantes. Quando eu era aluno do Ensino Médio, um professor meu disse que não era aceito que eles dessem nota zero aos estudantes. Conversei com uma senhora, que também já foi minha professora, e ela disse que a Secretaria de Educação orienta os diretores das escolas a não permitir que os alunos sejam mandados para a secretaria ou a baixar pontos dos estudantes, dessa forma fica meio difícil ter o domínio das salas de aula.

A educação no Brasil se tornou um caso tão sério que é inadmissível que os professores reprovem grandes quantidades de alunos, mesmo muitos deles não sabendo o conteúdo, tirando notas baixas e sendo indisciplinados. Os professores são obrigados a passá-los de ano, tirem a nota que tirarem.

O respeito pelo professor é essencial para que tenhamos uma educação de qualidade e tenhamos um país desenvolvido. Existem algumas teorias da conspiração que tentam explicar o motivo dessa crise educacional que nosso país enfrenta. Uns falam que o governo quer que os alunos continuem sem instrução para se criar uma sociedade passiva quanto aos atos de corrupção, outros falam que para Brasil não aparecer entre os países com maiores índices de reprovação e ter uma melhor reputação internacional, o governo obriga os professores a não reprovarem grandes quantidades de alunos. Não cabe aqui especularmos sobre teorias da conspiração, mas se sabe que

NOTA DO ORGANIZADOR. Apesar de respeitar a opinião do autor, percebe-se nessa análise uma generalização, colocando-se na conta do Programa Bolsa Família algumas atitudes individuas de algumas famílias. Um dos critérios para permanecer e receber o Bolsa Família é estar com os filhos devidamente matriculados e com frequência em dia. 
o professor foi completamente desarmado contra a indisciplina dos alunos, restando apenas ver sem poder fazer nada alunos seus passando de ano sem saber de quase nada ou, em muitos casos, de nada.

\section{Considerações finais}

Não sou defensor do modelo de ensino autoritário, nem tampouco acho que seja a solução para a crise educacional que se encontra em nosso país, mas creio que nossos professores precisam ser mais valorizados, tanto pela sociedade, quanto dentro das salas de aula. Em todas as salas do ensino médio e fundamental que entrei havia casos de indisciplina, umas em maior, outras em menor escala. Creio que em toda escola do ensino regular, seja pública, seja privada, o professor terá de lidar com questões de indisciplina e falta de interesses por parte de alguns alunos.

Uma sociedade com muitos deveres e poucos direitos é uma ditadura, uma sociedade com muitos direitos e poucos deveres é uma anarquia, então deve haver um equilíbrio para que não haja nem uma ditadura nem uma anarquia, essa é a lição que quero deixar para os leitores desse artigo. As salas de aula anterior às décadas de 1990 parecia uma mini ditadura, com professores que de forma alguma toleravam a indisciplina. As salas de aulas após essa década parecem mais uma verdadeira anarquia, com alunos que se comportam mal, e não se interessam pelas aulas.

É necessário que os professores voltem a ter o respeito que tinham antes, para isso é necessário que sua autoridade na sala de aula seja restituída. É preciso que as famílias tenham consciência da importância da formação educacional de seus filhos e voltem a ensinar às crianças o devido valor do estudo e da escola, isso será uma peça fundamental na valorização da classe docente. Se a família não se preocupa com a educação dos filhos e o governo tira a autoridade de sala de aula, como querem que o professor resolva tudo sozinho? Esse é um dilema que não vai ser tão fácil de responder e muito menos de se resolver.

Com a desvalorização dos profissionais da educação, eu posso afirmar com todas as letras que quem realmente perdeu não foi o professor, que tem de suportar o descaso e o desrespeito de seus alunos. Quem perde de verdade são os próprios alunos, que por não adquirirem o conhecimento e a instrução necessária não conseguem ingressar no nível superior e continuam na classe baixa, desempenhando muitas das vezes os mesmo empregos de seus pais. Nada contra esses empregos, acho que são essenciais para a sociedade, mas é como dizem por aí: "estudem, porque uma caneta é mais leve que uma pá". 
Nossa Gente,

Nossa História

o Ceará Republicano

A maioria dos alunos que conheci no estágio do Ensino Fundamental parecia estar adormecida quanto a importância da escola em suas vidas, dessa forma nunca sairá do atraso, nossos profissionais são capacitados, mas não valorizados. Aí está o segredo para a derrota da nossa educação. 


\section{Parte 3}

\section{Culturas e sociabilidades diversas}





\title{
13. Historiografia e cinema: percepções da diversidade na sétima arte
}

\author{
Vinícius Pereira de Sousa ${ }^{1}$
}

\section{"Uma câmera na mão e uma ideia na cabeça." \\ Glauber Rocha}

\section{Introdução}

Este trabalho abordará a cinematografia como linguagem, que em um dos seus aspectos tem a capacidade de representar porções de realidade(s), dando voz e vez a uma infinidade de narrativa(s). Usufruindo da linguagem cinema, diretamente ou indiretamente, os debates sobre abjetos começam ocupar espaços que os representa, vezes de formas negligenciadas outras em situações inferiores, tais inclusões iniciam-se através dos estereótipos. Esses sujeitos desviantes são excluídos e isolados, seus comportamentos são tidos como fora dos padrões aceitos pela sociedade que historicamente visa os costumes da heteronormatividade e patriarcado. Em cada tempo histórico, o debate envolve um pensamento diferente, pois em cada período variam-se os valores sociais, tanto quanto os espaços geográficos que os envolvem. Já a inclusão desses personagens se apresenta de formas variadas, uma vez que é atribuído um sentido de luta pela resistência e sobrevivência que interage em oposição às normas preestabelecidas e conservadas. Por fim, faz-se a análise dessas obras cinematográficas desde suas narrativas e alegorias, que então surgem como objetos de significâncias para a representatividade das ações culturais nas quais esses personagens são incluídos, a arte nesse trabalho, em exclusivo, vem para discutir a esfera do olhar sob uma ótica queer.

Como sabemos, o cinema é um fornecedor de possibilidades, preconceitos, segredos e funciona também como reforço de atitudes da sociedade para falar ou não falar de algo. Dentro e fora das telas, esses personagens lutam na tentativa de conquistar lugares e posições plurais, fugir dos estereótipos e refletir seu lugar no mundo como sujeito que escreve a própria história, esse é um caminho longo para ser percorrido.

As produções carregam consigo ações de comunicação, onde se põe um artefato ideológico para ser representado, é onde entra a relação câmera e

Estudante do Curso de História da Universidade Estadual Vale do Acaraú-UVA. E-mail: vinicius.

vr.rodrigues88@gmail.com 
objeto, observando dois pontos importantes, quem é câmera? Pois esse surge de um discurso particular, quem é objeto? Sujeito receptor dessa informação. A interrogativa é de onde surge o interesse por esse conteúdo por parte do alocutário? Jodelet (2001), que aborda essas relações sociais de comunicação e representação, afirma:

Primeiro, ela (a comunicação) é o vetor de transmissão da linguagem, portadora em si mesma de representações. Em seguida, ela incide sobre os aspectos estruturais e formais do pensamento social, à medida que engaja processos de interação social, influência, consenso ou dissenso e polêmica. Finalmente, ela contribui para forjar representações que, apoiadas numa emergência social, são pertinentes para a vida prática e afetiva dos grupos ${ }^{2}$.

Segundo o pensamento da autora, existe uma alteridade posta em cartaz, essa necessidade de identidade ou não depositada no outro. Referente a esse discurso, atentamos ao conteúdo da imagem fílmica como essa base de informações, e a alteridade o botão que liga o espectador como esse sujeito.

Concomitante a esse conceito, "o corpo comunica". Carrega em si informações, traços e características que o definem enquanto tal e que, impreterivelmente, dotam-no de significados singulares, nos quais as vivências e escolhas perpetradas na história de nossas vidas estão inscritas (THEODORO, 2014, p. 3-4).

Essa relação midiática está ligada ao direito ao corpo enquanto objeto comunicativo. O objeto fílmico é lugar de memória, que Nora (1993) comenta "nascem e vivem do sentimento que não existe memória espontânea, que é preciso criar arquivos" (p. 13).

Pensar o próprio corpo de uma produção audiovisual está ligado a narrativas, e logo entra o papel da história, que é uma corrente de pensamento que se desenvolve entre lembranças e esquecimentos. Mas uma vez que o presente torna-se passado, o que acontece? Um fato ou personagem é esquecido? Esse personagem estaria destinado ao nada?

É então que o historiador faz uso das fontes e recorre à memória para desenvolver e dar vida ou reviver, criando um cenário de narrativas, que até então, nos tempos em que ele pesquisa ninguém tinha se atentado a questões de tamanha relevância, ou seguido sua linha de discurso.

Refletir o papel do historiador é pensar um sujeito que anda sempre desejando (não afirmei que consegui) fazer com que o passado tenha um refle- 
xo no presente e que esse presente se reconheça nesse passado, que muita de suas vezes anda em dias de esquecimento.

\section{Cinema e o Queer}

Iniciando com a teoria queer, que vem ganhando destaque dentro das pesquisas acadêmicas no campo das ciências humanas, com seus diferentes autores e autoras que contribuíram para sua conceituação, assim a escritora Jagose (1996), no livro Queer Theory, apresenta uma base para iniciar-se essa compreensão: "A teoria queer desenvolve-se a partir de um reordenamento gay e lésbico das representações pós-estruturalistas da identidade como constelação de posições múltiplas e instáveis", percebe-se então um discurso móvel e plural quebrando correntes como a ideia de verdade e objetividade.

Contribui para esse debate a historiadora brasileira Gaucira Lopes Louro, em Um corpo estranho: ensaios sobre sexualidade e teoria queer, do ano de 2004, que faz uma acepção do queer:

Queer é tudo isso: é estranho, raro, esquisito. Queer é, também, o sujeito da sexualidade desviante - homossexuais, bissexuais, transexuais, travestis, drags. É o excêntrico que não deseja ser integrado e muito menos tolerado. Queer é um jeito de pensar e de ser que não aspira ao centro e nem o quer como referências; um jeito de pensar que desafia as normas regulatórias da sociedade, que assume o desconforto da ambiguidade, do entre lugares, do indecidível. Queer é um corpo estranho que incomoda perturba, provoca e fascina ${ }^{3}$.

Já a filósofa pós-estruturalista Judith Butler (2007), que tem grande bagagem sobre trabalhos que abordam os discursos construídos sobre esses corpos ditos abjetos nas conjunturas sociais, explica:

O abjeto designa aqui precisamente aquelas zonas "inóspitas" e "inabitáveis" da vida social, que são, não obstante, densamente povoadas por aqueles que não gozam do status de sujeito, mas cujo habitar sob o signo do "inabitável é necessário para o domínio do sujeito circunscrito ${ }^{4}$.

É naturalizado na sociedade contemporânea ocidental um discurso opressor para com as pessoas da comunidade LGBTTTI ${ }^{5}$, pois essas não car-

LOURO, Guacira Lopes. Teoria queer - uma política pós-identitária para a educação. Estudos Feministas, Florianópolis, Vol. 9, N.2, p. 541-53, 2001.

4 BUTLER, Judith. Corpos que Pesam: sobre os limites discursivos do "sexo" In: LOURO, Guacira Lopes (org.). O Corpo Educado: pedagogias da sexualidade. Belo Horizonte: Autêntica, p. 155, 2007.

5 É a sigla utilizada pela juntar em família lésbicas, gays, bissexuais, transexuais, travestis, transgêneros e intersexuais para reafirmar os valores da comunidade a união pela luta em seus direitos e busca por igualdade, quando se afirma LGBT, não se trata de um gênero ou sexualidade, mas de uma ideia. 


\section{Nossa Gente,}

regam consigo o discurso da heteronormativo, logo esses sujeitos são separados dos padrões dominantes e representados de maneiras inferiores, então em suas representações simbólicas são apresentadas dentro e fora da mídia com esse tratamento de corpos abjetos, que segundo Richard Miskolci:

O abjeto é algo pelo que alguém sente horror ou repulsa como se fosse poluidor ou impuro, a ponto de ser o contato com isso temido como contaminador e nauseante. Quando alguém xinga alguém de algo, por exemplo, quando chama essa pessoa de "sapatão" ou "bicha", não está apenas dando um "nome" para esse outro, está julgando essa pessoa e a classificando como objeto de nojo. Abjeto e obsceno (que significa fora de cena) se aproximam, revelando o que a sociedade preferia não ver e que, ao adentrar o espaço público, causa repugnância e repúdio. A partir da ideia de abjeção, compreendemos a dinâmica coletiva que gera a injúria e a violência contra aqueles que explicitam a instabilidade dos gêneros e, das formas as mais diversas, encarnam a diferença, o que não se anula na familiaridade do óbvio ou na reconfortante mesmice em que descansa o olhar cotidiano ${ }^{6}$.

Neste sentido, essa investigação tem como propósito incluir a reflexão sobre a teoria queer, que afirma a existência de sujeitos oprimidos pelo gênero e sexualidade no campo histórico dentro do cinema brasileiro, indo ao encontro e entendimento de resistências criadas por esses personagens, que buscam resistir para existir, em um cenário de heteronormatividade. Objetivando problematizar a padronização e difusão de relações patriarcais, tanto no plano político e sociocultural e em aspectos visuais, compreendendo as influências que ocorrem a partir da difusão desses conteúdos $\operatorname{artivistas}^{7}$ de resistência.

A problematização desses objetos de pesquisa, tanto o cinema como o queer que partem para a linha histórica, consiste em refletir inclusive sua condição de arquivos. Michael Foucault (2004) diz que não é a quantia de textos que foram preservados por um grupo, nem mesmo as marcas que foram salvas em ruínas, "mas o jogo de regras que determinam, em uma cultura, o surgimento e o desaparecimento de enunciados, sua remanescência e eliminação, sua existência paradoxal de acontecimentos e de coisas". Michael Foucault apresenta:

Analisar os fatos do discurso no interior do meio comum do arquivo é considerá-los não como documentos (de um signi-

6 MILSKOLCI, Richard. Teoria Queer: um aprendizado pelas diferenças. Belo Horizonte: Autêntica Editora, p. 40-41, 2012.

7 Para melhor compreensão do Artivismo, ler: "Artivismo - Política e Arte Hoje" (2007), de Miguel Chaia, professor do Departamento de Política e do Programa de Pós-Graduação em Ciências Sociais e pesquisador do NEAMP (Núcleo de Estudos em Arte, Mídia e Política), da Pontifícia Universidade Católica de São Paulo. 
ficado mascarado ou de uma regra de construção), mas como monumentos; é - sem contar com qualquer metáfora geológica, sem nenhuma atribuição de origem, sem o menor gesto em direção a concepção de uma arca - empreender o que se poderia chamar segundo os direitos lúdicos da etimologia, de alguma coisa como uma arqueologia ${ }^{8}$.

Compreendendo a possível participação das partículas desses dois grupos existirem, tendo de um lado a teoria queer enquanto relação de sujeitos e corpos estranhos, do outro a sétima arte, com sua bugiganga de representação visual, juntas para a formação de um novo fruto, que seria o cinema queer. Pensado aqui como a categoria de recorte do próprio cinema em seu conteúdo de representação, pois assim como existe o finitos dentro de infinitos, o queer é um infinito (pensado como discurso das representações a partir das narrativas particulares de um órgão pensante) que busca um caminho possível dentro do cinema.

Esse panorama de luta que se encontra nas imagens tem como cena um espaço simbólico das representações, como discute Pesavento:

[...] a incorporação da dimensão simbólica para a análise das formas de organização social, como uma forma de entendimento segundo a qual os homens elaboravam formas cifradas de representar o mundo, produzindo palavras e imagens que diziam e mostravam mais além do que era expresso e mostrado nos registros materiais ${ }^{9}$.

Esse cenário tem como plano de fundo a representação acerca de personagens que transitam no próprio cinema. É lá onde se encaixam a não aparição, a não representatividade e o estereótipo, que cria a partir de então uma ausência e necessidade de falar sobre eles, dando-lhes o direito a voz e a vez. 
Nossa Gente,

Nossa História

o Ceará Republicano

\section{Bichas Queer no Cinema brasileiro}

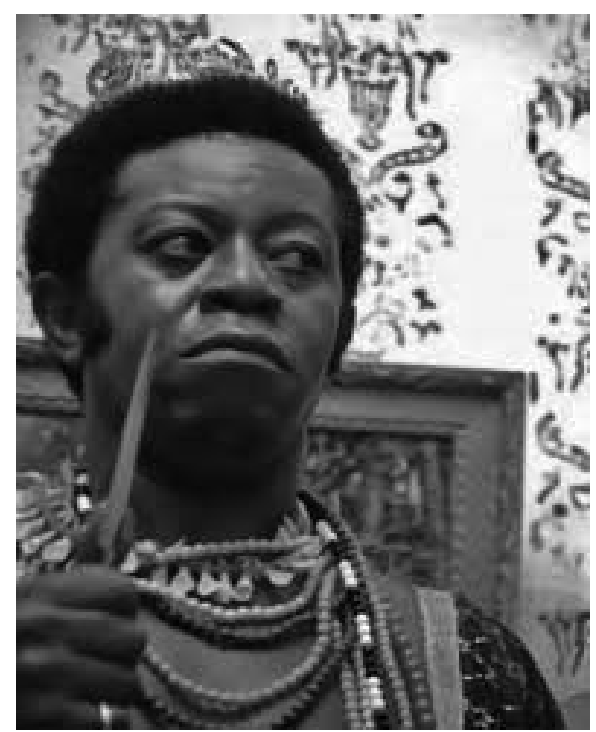

Figura 1 - Still da cena do filme Rainha Diaba do ano de 1974 (Disponível em: < 162 http://cineugenio.blogspot.com.br/2014/03/roger-corman-tarantino-e-almodovar. html $>$ Acessado em 04 set. 2018)

Antonio Carlos da Fontoura foi diretor de um filme que carrega a importância em seu papel de representatividade para seu período, trata-se do filme Rainha Diaba, do ano de 1974. Período esse que o Brasil se encontrava em ditadura militar, rodeado pela censura nas artes e meios de comunicação, opressão que era frequente para sujeitos que opunham-se ao sistema ditador, levados à tortura e o silenciamento por via de chantagem ou mesmo morte.

O longa representa um Rio de Janeiro de drogas, prostituição e travestilidade, o filme gira em torno do mundo do tráfico de drogas e a chefa dessa quadrilha era a popularmente conhecida Rainha Diaba, como se apresenta no filme, personagem negra que comanda a máfia, os seus agentes fieis são gays e travestis, que eram olhos e ouvidos de Diaba por toda a cidade.

Sobre essas personagens travestidas, como destaca Pelúcio (2006), não se definem homens homo orientados, estão no caminho da personificação de sua imagem e suas práticas de afetividade e desejo voltadas para com os homens, mas os desenhos dos seus corpos são almejados para uma imagem do feminino como afastamento dos padrões masculinos.

No debate atual, fora dos grupos que discutem gênero e sexualidade, tem que se compreender o que compõe ou tenta-se compor a imagem de uma travesti, que é considerada por Borba e Ostermann (2008) um indivíduo 
biologicamente masculino que, através da utilização de mecanismos, afeiçoa seu corpo com atributos simbolicamente agregados à imagem do feminino.

Voltando ao filme, pouco se nota a presença de policiais, pois o debate gira em torno dos traficantes e de um pequeno romance, mas deixando claro que a figura central do filme era a Rainha Diaba e os momentos eram em maioria voltados a representar o mundo travesti da época.

É perceptível um instrumento utilizado atualmente por travestis e transexuais periféricas dentro do filme, a navalha, hoje adaptada para a gilete, comumente como objeto de defesa de travestis que permeiam o meio de prostituição, para autodefesa utilizam esse objeto nas suas vidas noturnas, a navalha do mesmo modo se destaca como esse um instrumento de segurança de Diaba e ao mesmo tempo mostra o poder dentro do seu território.

Em um período movimentado pela censura a instauração da Lei $n^{\circ} 5.536$, criada em te novembro de 1968, que gerou curso de Técnico de Censura, exigindo formação em Direito, Jornalismo, Ciências Sociais, Sociologia e Pedagogia, e concomitantemente no Conselho Superior de Censura - CSC, como último meio para que se recorrer às decisões do Diretor da Censura Federal, assim como aborda a autora: "[...] mais uma vez, a censura se reorganiza para melhor executar a tarefa de fortalecimento do regime, que neste momento significava a criação de condições para o fechamento político que 163 se daria em 13 de dezembro de 1968" (Souza, p. 13, 2015).

Rainha Diaba é um filme que desafia a sociedade da época em aspectos políticos e no próprio contexto de representação, uma travesti negra que intervém enquanto dona de um sistema de tráfico, sendo apresentada nos anos 70. Em uma sociedade racista e regida por um sistema regimentado por militares, que utilizavam a censura como a opressão física e moral para silenciar quem se manifestava contra a índole e a moral que os governantes pregavam, então esse filme é marco de representatividade gay/travesti da época de ditadura e posterior a ela. 


\section{Nossa Gente,}

Nossa História

o Ceará Republicano

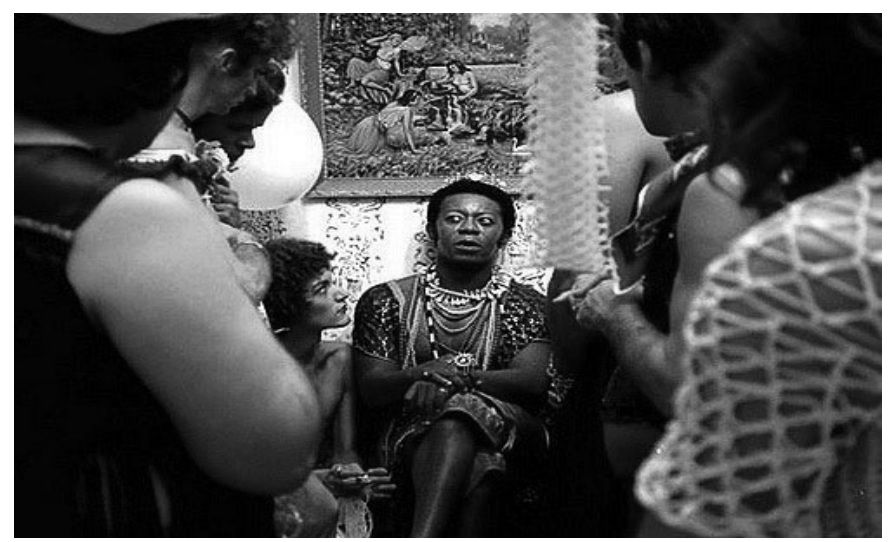

Figura 2 -Filme Rainha Diaba do ano de 1974 (Disponível em: < https://www.flickr. com/photos/47176018@N02/4328006040> Acessado em 04 set. 2018)

\section{Mais uma bicha preta favelada dentro do cinema}

No ano de 2002 era lançado o filme Madame Satã, dirigido por Karim Aïnouz, que trabalhou uma personagem que hoje seria considerada uma drag queen. Essa pessoa era uma brasileira que viveu com uma figura de re164 presentatividade das vidas noturnas da cidade de Rio de Janeiro na primeira metade do século XX.

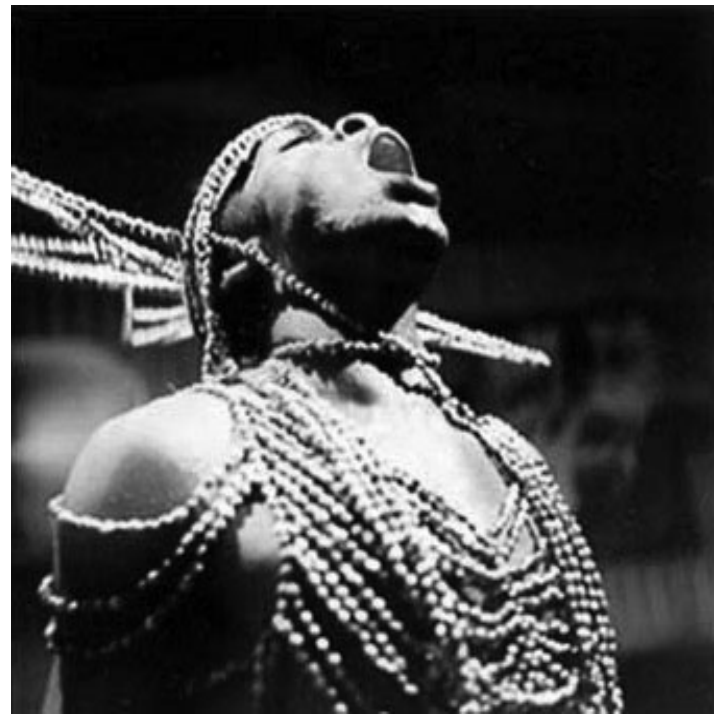

Figura 03 -Filme Madame Satã do ano de 2002. (Disponível em: < http://www.adorocinema.com/filmes/filme-45359/creditos/> Acessado em 04 set. 2017)

Representando a cultura marginal urbana de cada cidade carioca, no filme estava exposta a história real de Madame Satã, uma figura pobre, negra, 
ex-presidiária e gay, que vestia-se de Drag para ganhar a vida fazendo shows na tentativa de ajudar a família. Nesse filme está sendo apresentado em palco um personagem que se veste com o intuito de brilhar enquanto artista, mas sofre com a opressão, devido a sua cor de pele e sexualidade.

A obra se apresenta de modo indenitário da vida de João Francisco, pessoa que inspirou o filme, deixando clara essa relação de instáveis conflitos dentro do próprio personagem em seu processo de aceitação enquanto sujeito homoafetivo, pois o próprio João, enquanto artista que representa no palco, era aclamado por uns e repudiado por outros.

Para além do que o filme representa em termos de estética, ele se abre no lugar de artefato político ao tempo, se estabelece em representar, alargando as ideias, personificações do passado e presente, assim como atenta Stuart Hall: "O argumento que estarei considerando aqui é que, na verdade, as identidades nacionais não são coisas com as quais nós nascemos, mas são formadas e transformadas no interior da representação", mediante representar e divulgar uma imagem ou ideia.

Desta forma, o filme está a caminho da formação de uma nova consciência para aquele que o assiste no tempo e na sociedade em que está inserido, pois além de contar uma história que se baseia em fatos e pessoas reais, ele argumenta com ideias de luta e identidade para sujeitos LGBTTTI e para as demais pessoas, em especial os queer negros.

\section{Praia do Futuro, uma ponte entre Ceará e Berlim}

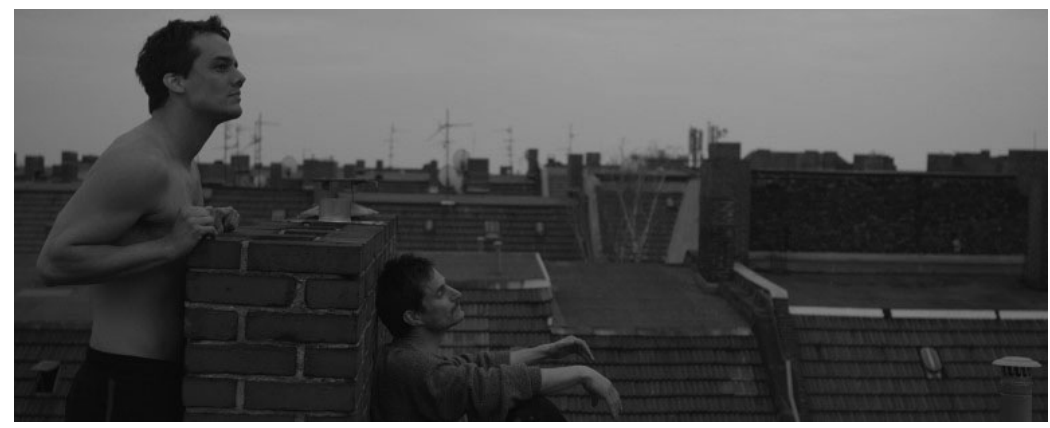

Figura 4 -filme Praia do Futuro do ano de 2014 (Disponível: < http://www.adorocinema.com/filmes/filme-204022/ / > em acessada 05 de out. de 2018)

O longa Praia do Futuro, que estrou em maio de 2014, traz uma correlação entre Brasil e Alemanha. Inicialmente, conta a história de um salvavidas, Donato (Wagner Moura), que se aproxima de um homem, Konrad (Clemens Schick), a primeira pessoa que salvou de afogamento, e ambos se apaixonam. O socorrido é um alemão que acabou perdendo o companheiro 
para o mar. Com o envolvimento amoroso, o salva-vidas vai embora, morar na Alemanha, deixando para trás seu irmão mais novo, sua mãe e seu emprego.

Vale abordar sobre o cenário em destaque escolhido pelo Diretor Karim Aïnouz (Fortaleza, por ser o local onde ele nasceu, e Berlim, o local onde ele morava no período de produção do longa), na primeira das três partes em que o filme é dividido, o cenário Inicial é a Praia do Futuro, em Fortaleza, no Ceará. Nesse local ele mostra todo um recorte do litoral, como o sol, barracas, praias, destacando o espaço dos banhistas, corridas de motocross, brincadeiras na beira da praia, espaços públicos e privados na perspectiva do olhar do salva-vidas No segundo ato, já parte para o espaço de Berlim, na Alemanha, assim como na terceira.

Aqui está sendo mostrado um personagem que ultrapassa as margens nacionais para vivenciar sua relação com seu companheiro. Representando um grupo, que identifica-se com o seu personagem, que saem de seu lugar de origem, muitas vezes a cidade natal, onde tem um círculo de pessoas que o predem num campo de heterossexualidade que o olhar desviante não pode atuar, para viver uma relação menos conflituosa, tendo a partida como escolha de liberdade.

A personificação do ator entra em debate a partir do seu histórico de 166 produção. Aqui temos como destaque Wagner Moura atuando em um papel gay e apresentando-se em uma cena se sexo. Alex Antunes aponta que "a sensação é de que muita gente vai ao novo filme de Moura, o Capitão Nascimento de Tropa de Elite, na confiança e boa fé, sem ter informação do roteiro" (2014). A personificação da imagem do ator conta como objeto de ação política e de intervenção sobre normas já estabelecidas ao corpo e a imagem, podendo causar conflitos com uma sociedade de "mente fechada" que pouco busca compreender o papel do ator, como no seguinte caso: "um usuário do Facebook publicou que o gerente de um cinema em Aracaju teria sido ameaçado por rapazes inconformados em terem ido parar, sem aviso, num filme gay" (ANTUNES, 2014). O filme se apresenta com um perfil que incomoda um grupo heteronormativo que busca na imagem do ator virilidade e masculinidade, não que Praia do Futuro não apresente esses temas, mas não da forma como um público heterossexual espera.

Para além de um "filme gay", estão sendo alocadas outras questões no filme, assim como territorialidade, o trabalho como salva-vidas, o esporte de motocicleta, a família, morte etc., mas é claro que o debate central vai abarcar todas essas relações, em principal a viagem e vivência do personagem enquanto gay que quer afastar-se do seu local de origem para evitar uma relação conflituosa com seu lugar. Assim como comenta o diretor: 
lado, mas também porque tinha vergonha. $O$ irmão fala que ele foi dar o cu escondido no Polo Norte, e ele foi dar o cu escondido no Polo Norte, sim. O cara não teria sumido desse jeito se não fosse gay. Nem teria sentido existir este filme se ele fosse hétero. ${ }^{10}$

A obra caminha para o debate do deslocamento e afastamento desse personagem de sua vida, amigos, família e trabalho para sentir-se livre e vivenciar sua homoafetividade em um ambiente que para ele é menos conflituoso. Por conta de ser desconhecido e os apegos e memórias a Berlim não serem tão fortes e marcantes como o seu passado na Praia do Futuro.

\section{História e Cinema: veredas que se encontram}

Esse sinônimo de falta vem ao encontro de produção fílmica, não com tentativa de abarcar toda a realidade, mas pensar realidades possíveis que se justapõem com essas camadas de filmes, que surgem para apresentar personagens esquecidos e marginalizados dentro da sétima arte, citando alguns exemplos, os personagens gays, afeminados, travestis, lésbicas etc.

Personagens que atento, são refletidos não apenas no espaço de ficção, mas estamos no campo da representação, que precisam ser pensadas em universos possíveis de identidades nos aspectos micro culturais. Para assim compreender em nível maior essas relações que são tabus permeados no seio social até os dias atuais.

Incluindo que essa história micro vem como parte de um quebra-cabeça maior, focando para onde e como olhamos, então se começa a observar um universo menor. Lima (2006) aponta a história desses sujeitos micros:

[...] de que se pode revelar muito olhando com atenção para um mesmo lugar onde aparentemente nada acontece, sugere, se não um procedimento, ao menos a qualidade de uma observação ou de uma perspectiva frente aos objetos de análise. Uma atitude intelectual que se alimenta da convicção de que o olhar através do microscópio, o interesse pelo minúsculo - ou ao menos, no limite, pela miudeza, ou por aquilo que mais facilmente se negligencia -, pode revelar dimensões inesperadas dos objetos e, com sorte, perturbar convicções arraigadas no domínio da história ${ }^{11}$.

10 Entrevista de Karim Aïnouz ao portal iG. Disponível em:http://ultimosegundo.ig.com.br/cultura/cinema/2014-05-19/cineasta-karim-ainouz-por-que-uma-pessoabeijar-outra-e-polemico.html Acesso em: 04 Julho 2017.

11 LIMA, Henrique Espada. A micro-história italiana: escalas, indícios e singularidades. Rio de Janeiro: Civilização Brasileira, p. 13-14, 2006. 
Pensar essas questões é ir direto ao que Barros (2004) aborda em O Campo da História:

\begin{abstract}
A micro-história não se relaciona necessariamente ao estudo de um espaço físico reduzido, embora isto possa até acontecer. O que a micro-história pretende é uma redução na escala de observação do historiador com o intuito de se perceber aspectos que de outro modo passariam despercebidos. Quando um micro-historiador estuda uma pequena comunidade, ele não estuda propriamente a pequena comunidade, mas estuda através da pequena comunidade ${ }^{12}$.
\end{abstract}

Ao iniciar a reflexão nos estudos do cinema em perspectivas históricas trilhando caminhos da ficção, me perdi em uma geografia de caminhos não trilhados, é algo que a academia não norteou enquanto fonte de pesquisa, muitas vezes pincelado como importante, mas não discutido a fundo.

Buscando então em Michel de Certeau uma ajuda para compreender e sitiar esse objeto/sujeito de pesquisa que aborda a ficção, "apesar do quiproquó de seus estatutos sucessivos ou simultâneos [... a ficção é um discurso que dá forma ao real, sem qualquer pretensão de concebê-lo ou de credenciado por ele.", e complementa Certeau: "opõe-se, fundamentalmente, a uma 168 historiografia que se articula sempre a partir da ambição de dizer o real" (CERTEAU, 2012, p. 48).

Esse ato de "dar forma ao real" repassa que esse "real" é uma linguagem universal e positivista, que visa uma história ocidental estereotipada e higienizada, fugindo dessa historiografia abordada por Michel de Certeau, que age de modo a afirmar que houve uma história certa e outra errada.

Mediante a abordagem, o que está em jogo aqui não é se o cinema caminha em perspectivas reais ou ficcionais, mas que ele comunica-se e multiplica-se ao representar uma realidade mostrada. Para além, refletir quantas realidades possíveis podem ser pensadas a partir dele.

Para melhor entender essa relação entre cinema, história e tempo, criei um esboço de roteiro de um filme imagético, nele a narrativa é pensada a partir de uma criança que brinca na beira de um grande rio, tentando segurar um pouco de água em suas mãos, mas essa água escorre pelos seus pequenos dedos.

O historiador é como a criança que brinca com a fonte da mesma forma que o menino brinca com a água, e o grande rio em suas partículas concentra-se no cinema e o seu tempo, essa pequena porção de história que ele tenta segurar ainda lhe escorre, fluindo rio abaixo, fazendo-o perceber que a 
história e o cinema estão ininterruptamente em movimento, assim como rio que não é algo imóvel e congelado.

Deste modo, não se deve prender e congelar o rio/cinema como rotulação ou definição de objeto ou sujeito exato, mas observá-lo como um rio que dança e ao ser olhado pela segunda vez, não vai carregar consigo as mesmas águas, que foram vistas na primeira vez, é um rio que age em conjunto, escorrendo entre as pedras da ficção e das realidades possíveis ${ }^{13}$.

Esses personagens que foram esquecidos ou cobertos por uma capa heterossexual, vão ao palco com uma necessidade constante de identidade que os reconheça e diga que eles existem, não apenas como "bichas loucas" e/ou "afeminadas", mas como identidades múltiplas que o queer produz. Ele é a diversidade e não é uma fábrica de padronização e redundâncias.

Quando falo dos estereótipos, quero atentar que se faz necessário uma aceitação social desses personagens também com essas características de "bichas loucas" ou/e "afeminadas", pois a família LGBTTTI tem como seus princípios de luta a não rotulação e categorização de uma pessoa enquanto seus costumes. Assim, pensa as pessoas para além de um número ou dispositivo de ação. Esses atuantes LGBTTTI são cenas censuradas de uma sociedade enraizada com valores patriarcais, que se diz de boa índole, valorizadora 169 da família e dos bons princípios.

O cinema queer busca a mesma perspectiva de quebrar tabus. O simples fato de criação de conteúdos que ajam como fontes de representação da porção das realidades queer, é uma proposta desse trabalho. Descontruindo uma história do cinema criada por modelos patriarcais de imposição ao sujeito e ao corpo $^{14}$.

Discutindo as mesmas perspectivas de imagem e cinema, vamos ao encontro do que o filósofo e sociólogo Walter Benjamim (1987) apresenta:

O filme serve para exercitar o homem nas novas percepções e reações exigidas por um aparelho técnico cujo papel cresce cada vez mais em sua vida cotidiana. Fazer do gigantesco aparelho técnico do nosso tempo o objeto das inervações humanas - é essa a tarefa histórica cuja realização dá ao cinema o seu verdadeiro sentido ${ }^{15}$.

13 Ver Platão, Crat. 401 d, 411 b, 439 c; Theaet. 156 a, 160 d Soph. 249 b; Phaed. 90 b; Filebo. 43 a.

14 Francisco Ximenes Guimarães, 82 anos, agricultor aposentado, e antigo trabalhador de engenho. Entrevista realizada pela autora em 29 de maio de 2017. Alcântaras-CE.

15 BENJAMIN, Walter. A obra de arte na era de sua reprodutibilidade técnica. In: Magia e Técnica, Arte e Política. São Paulo: Brasiliense, p.174, 1987. (Obras Escolhidas v.1). 
Neste caso, é necessário refletir o valor histórico e a ligação que o cinema estabelece com um novo arquivo histórico - o audiovisual. Esse vem contemplando as realidades ou não, tem como uma das suas funções a ação de testemunhar o contexto sociocultural. Então ele é pensado como um documento de extrema significância a partir do momento que ele deixa o campo do passatempo e chega ao campo da contextualização.

Até mesmo no campo do entretenimento, como discute um dos percussores das relações entre cinema e história, alargando as possibilidades de se pensar a fonte histórica para além de um arquivo manual e sólido, apresentase o debate do historiador francês Marc Ferro (1993):

O filme aqui não é considerado do ponto de vista semiológico. Não se trata também de estética ou história do cinema. O filme é abordado não como uma obra de arte, porém, como um produto, uma imagem-objeto, cujas significações não são somente cinematográficas. Ele vale por aquilo que testemunha ${ }^{16}$.

Ferro, anos seguinte na obra O filme: uma contra-análise da sociedade, indica:

\begin{abstract}
Partir da imagem, das imagens. Não procurar somente nelas exemplificações, confirmação ou desmentido de um outro saber, aquele da tradição escrita. Considerar as imagens tais como são, com a possibilidade de apelar para outros saberes para melhor compreendê-las. Assim o método que lembraria o de Febvre, o de Francastel, de Goldmann, desses historiadores da Nova História, da qual se definiu a vocação. Eles reconduziram a seu legitimo lugar as fontes de origem popular, escritas de início, depois não escritas: folclore, artes e tradições populares etc. Resta estudar o filme, associá-lo ao mundo que o produz. A hipótese? Que o filme, imagem ou não da realidade, documento ou ficção, intriga autêntica ou pura invenção, é História; o postulado? Que aquilo que não se realizou, as crenças, as intenções, o imaginário do homem, é tanto a História quanto a História ${ }^{17}$.
\end{abstract}

Propõe-se nesta pesquisa pensar o cinema também como um objeto de arte, como Ferro se opõe, deixando claro o valor de testemunho do objeto cinematográfico, refletido como expressão do emblemático, enfatizando o poder do discurso aqui aplicado no visual do pós-estruturalismo, como propõe Woodward: "A representação inclui as práticas de significação e os sistemas simbólicos por meio dos quais os significados são produzidos, posicionando-nos como sujeito" (2007, p. 17).

16 FERRO, Marc. Cinema e história. Rio de Janeiro: Paz e Terra p.203, 1993.

17 FERRO, Marc. O filme: uma contra-análise da sociedade. In: LE GOFF, Jacques; NORA, Pierre (orgs.). História: novos objetos. Rio de Janeiro: Francisco Alves, p. 199-215, 1995. 
Marcado assim como artifício visível e público, relacionando-se às manifestações artísticas, aqui se destaca o cinema como simbólico, mediante ao que se aborda como representatividade e problematização. Referenciando não apenas como um objeto de estudo da história, nem tão pouco o que aconteceu e o que não aconteceu e nem mesmo o motivo desses, mas como ocorre à atuação dos sujeitos envolvidos no meio, pensar inclusive o cinema atrás das câmeras e seus bastidores.

Para continuar a compreender o queer enquanto corrente teórica, aqui numa acepção voltada aos movimentos sociais e de militância para com as minorias. Não esquecendo que esses movimentos também se constroem dentro da universidade, com produções acadêmicas. Assim como esta, o queer vai além da categorização de uma figura LGBTTTI, ele é um vocábulo que a sua semente germinou nos EUA, utilizado inicialmente de forma pejorativa, que remetia a uma linguagem de opressão e inferiorização, eram apresentados como "estranhos" e ou "esquisitos", essas pessoas não representavam uma heteronormatividade. No Brasil, essa figura será chamada de "bicha" ou "viadinha", com processo de discursos e compreensão acadêmica, os grupos sociais de militância se apropriam desse discurso e usam como partida de autoafirmação.

Afirmar-se queer não vai mais de encontro ao preconceito, e sim à liberdade e autoafirmação de quem o sujeito é, criando assim uma união dessas minorias, $\mathrm{o}$ antes isolado tem um porto seguro onde pode navegar, tem um vale onde pode viver e tem um lar que pode chamar de seu. O queer compreende-se para além do que a sua própria teoria propõe. Apresenta-se como uma rede que se conecta como, por exemplo, a importância da negritude, como discursos feministas etc. Esse discurso parte, de princípio, do campo singular e abraça-se em coletivo apresentando suas pluralidades:

O queer, portanto, não é uma defesa da homossexualidade, é a recusa dos valores morais violentos que instituem e fazem valer a linha da abjeção, essa fronteira rígida entre os que são socialmente aceitos e os que são relegados à humilhação e aos desprezos coletivos. (MISKOLCI, 2012, p. 25) ${ }^{18}$.

Reconfigura-se que a estrutura do queer, quando se aproxima da arte, apresenta-se como um artefato político de luta, quebrando uma corrente de estereótipos e encaixes, assim como o exemplo que apresenta Miskolci: “[...] a luta por desvincular a sexualidade da reprodução, ressaltando a importância do prazer e a ampliação das possibilidades relacionais".

Perceber assim, como aborda Richard "[...] associados à emergência de novos sujeitos históricos que passam a demandar direitos e também a in-

18 MILSKOLCI, Richard. Teoria Queer: um aprendizado pelas diferenças. Belo Horizonte: Autêntica Editora, p. 22, 2012. 
fluenciar na produção de conhecimento" (p. 13), entendendo que existe uma vontade que se diferencia dos padrões heteronormativos, não na busca de aversão, mas compreendendo o desejo como um ponto de pluralidades e não rotulação.

A sexualidade deve ser compreendida não como um impulso naturalizado de reprodução humana, mas de um ato decorrente do desejo, desta maneira alargam-se as possibilidades de pensar o próprio corpo e as maneiras de relacionamentos.

Exemplos concretos e frequentes no cotidiano são esses sujeitos postos à margem, com suas abjeções que permeiam novas veredas para o corpo, não apenas em argumentos do desejo sexual, mas no desejo de o corpo harmonizar-se para uma vivência significativa e digna em cada sujeito.

Em equivalência com o cinema, os novos meio de produção fílmicas vão ganhando mais força a partir do final dos anos 1980, assim como exposto no documentário Fabulous! The Story of Queer Cinema de Klainberge e Ades. Nesse documentário tenta-se compor o cenário de uma linha cronológica para produção do que chamam de "cinema queer".

Esse artefato torna o queer numa nova linha de reflexão para o contexto do cinema, caminhando por linhas históricas ocultadas ou silenciadas durante um período de produção, observando essas mudanças gradativas que vão surgindo com os momentos históricos, a partir da autoafirmação, da quebra do senso comum e a busca por políticas públicas de inclusão.

\section{Considerações finais}

O cinema aplica-se como um artefato cultural e uma ferramenta de ensino-aprendizagem, com sua película faz circular sentidos e ideias, dentre elas a sétima arte discursa sobre a significação ou ressignificação do ser homem e ser mulher. Expondo, então, a figura da família e os valores que estão atribuídos ao pai e mãe mediando-se nas estruturas de poder que ambos carregam. Alargar os campos de representatividade no cinema é agregar novas manifestações do desejo, corpo e modo de se expressar no mundo.

As faces de representatividade que mostram o gênero invisível e subalterno são múltiplas, com o maior discurso na busca por direitos nos campos de igualdade, esses símbolos de representação tornam-se mais frequentes no cotidiano social e mais aceitáveis. Logo, maiores demandas levam maior exposição das realidades dos sujeitos queer, se tornando uma figura cada vez mais frequente e comum nas telas, representar é afirmar ou reafirmar uma realidade que pode ou não querer ser assistida. 
Refletindo a perspectiva do olhar, quem olha e quem narra esse conteúdo fílmico, almejando um conteúdo cinematográfico múltiplo, que não apenas se encaixe na visão do homem heterossexual, mas que possa seguir discutindo o papel da mulher na direção de filmes.

Aspira-se um cinema com maior diversidade no olhar, que os olhares sejam olhares cada vez mais coloridos para assim descobrirmos outras histórias, outras narrativas e outras questões que precisem ser apresentadas na mesa da sétima arte.

Não deixando de pensar a estrutura que leva o cinema a se tornar possível, a arte de fazer, desde a atuação ao roteiro, frequentemente os filmes carregam memórias, simbologias e alegorias. O lugar por trás das câmeras é um ponto a ser estudado, desde a participação dos atores, desde quem escreve o roteiro, para além da realidade que eles querem apresentar, mas instigando conhecer a realidade de quem estuda para a arte se tornar possível. Debatendo então o papel de importância desses sujeitos, vezes que muitos dos papeis ou assuntos ainda são status para grupos de artistas e produtores. $\mathrm{O}$ ato de se aventurar continua sendo ainda um ponto de destaque, o novo parece aversivo e causar medo, mas esses agentes fazem com que a perspectiva do olhar trace novos caminhos, incentivando novos modos de pensar as relações de status que existem dentro de cada campo.

O cinema se aproxima de uma geração que está se reconhecendo e produzindo novas ideias voltadas para o queer, frutos, inclusive, de alguns filmes que foram apresentados aqui nesse trabalho.

Uma vez que "filmes mais velhos" são motivadores de novas produções e novas realidades, impulsiona-se e estimula-se cada vez a vontade de falar de mais e mais realidades.

É perceptível que com o passar dos anos o tema sobre o queer vai tomando outro viés de apresentação, que está estreitamente ligado com o seu tempo histórico.

Almeja-se que um dia esse trabalho seja desnecessário como militância, que o termo queer seja uma "palavra comum" e o que os filmes não sejam tidos como filmes queer/gays, mas apenas filmes, que em suas subjetividades apresentem narrativas cotidianas. O mesmo desejo para a família LGBTTTI, que um dia ao acordarmos, todas essas desgraças tenham sido apenas um pesadelo horrível, que tenhamos não mais dias vermelhos banhados de sangue, mas dias coloridos com maior diversidade. 



\title{
14. Espaços de sociabilidades homoafetivas em Sobral-CE (1950-2018)
}

\author{
Alan Silva de Morais ${ }^{1}$
}

\section{Introdução}

O presente trabalho tem como objetivo abrir uma discussão em relação à massificação da internet e a chegada das novas tecnologias por meio da sua crescente penetração no público em geral, que vem diversificando variadas possibilidades de conexões entre pessoas desconhecidas ou não, tendo como finalidade encontros íntimos homoafetivos, seja numa perspectiva virtual e possivelmente um contato presencial. Nesse caso, esses dispositivos móveis vêm desempenhando um papel importante como uma ferramenta de busca de parceiros ou de ambientes virtuais, possibilitados pela criação de aplicativos (apps) de relacionamentos, popularmente conhecidos como "aplicativos de pegação". Dessa forma, limito-me apenas a um deles, o "GRINDR", e sua utilização em Sobral-CE, pois a partir dele podemos propor uma espécie de panorama preliminar por meio da utilização do meio virtual na busca de relacionamentos afetivos e sexuais.

Através deste aplicativo em específico, nele os usuários podem buscar, cortejar ou encontrar parceiros em qualquer hora ou local mediante acesso à internet. Este aplicativo, enquanto mídia digital, tem permitido a socialização de desejos dissidentes, vem sendo estudado por pesquisadores em linhas antropológicas e mesmo comunicacionais, nos possibilitando perceber que essa socialização é bastante excludente, além de estar carregada de normas e comportamentos fixos e pareada aos padrões heteronormativos, partindo da premissa que a constituição da identidade de homens gays nessas mídias é um reflexo dos perfis históricos e mesmo conjunturais das homossexualidades. Além da notável existência da adaptação à situação estudada, levam-se em consideração os diversos meios de se representar por meio de imagens de perfis e principalmente a valorização da cultura da imagética de si e do corpo.

Graduando do $8^{\circ}$ período do Curso de História, na Universidade Estadual Vale do Acaraú-UVA.

O Grindr é um aplicativo para smartphones direcionado para gays, bissexuais e simpatizantes se encontrarem e se relacionarem. Conhecido no público gay como "aplicativo de pegação", o app (aplicativo) está disponível para download nas lojas virtuais App Store e Google Play (ALMEIDA, p. 27, 2015). 
$\mathrm{O}$ uso da internet tem modificado significativamente a maneira das pessoas se comunicarem nos últimos tempos. Uma forma que tem se destacado é a maneira que pessoas têm usado esta ferramenta para conhecer outras, tornando comum o seu uso para essa finalidade, seja para fins de amizades ou da procura de relacionamentos estáveis ou sexo casual. Atualmente, facilitada pelo usa da internet por meio da popularização de smartphones, relações afetivas de amizades e encontros são facilmente mediados através da internet. Porém, este trabalho está baseado nos usuários de aplicativos de encontros, popularmente conhecidos como aplicativos de "pegação", que têm como alvo o público gay, que surgiu da necessidade que homens gays possuíam de encontrar pessoas com a mesma orientação sexual. Como afirma o criador do Grindr, Joel Simkhai, em entrevista cedida ao site igay em 2013:

Como gay, sempre foi um desafio conhecer outros homens. Você olha para alguém e deduz se é gay ou não, mas nunca tem certeza. Procurei uma solução para saber quem era semelhante a mim ao meu redor, utilizando o celular. Quando o iPhone 2 foi lançado, contei a minha ideia para amigos, contratamos um desenvolvedor na Dinamarca e trabalhamos por seis meses. Em março de 2009 nós lançamos o aplicativo ao redor do mundo.

A necessidade de LGBTs desenvolverem mecanismos alternativos e não utilizarem a forma tradicional para manter as suas relações afetivas provém da exclusão sexual proporcionada pela sociedade. Segundo Judith Butler, a sociedade dispõe de uma matriz reguladora, a qual regula a vida sexual dos indivíduos, proporcionando uma heterossexualidade compulsória e uma binariedade de gênero (masculino e feminino), moldando os indivíduos até mesmo antes do seu nascimento, definindo a sexualidade dos indivíduos dentro do ventre da mãe. A sexualidade é reiterada constantemente pela performatividade, reproduzindo comportamentos designados masculinos e femininos, desde o mais simples ato, como o de sentar, permeando por toda a trajetória de vida do indivíduo sutilmente, naturalizando o artifício da sociedade ${ }^{3}$.

A possibilidade de uma relação iniciada na instância virtual, entre pessoas que comungam de uma mesma orientação sexual, cada vez mais se torna mais dinâmica que antigamente, permitindo entrar em contato com qualquer um desses usuários instantaneamente.

Buscamos analisar também os reflexos da homossexualidade em Sobral através das implicações, tais como preconceito e exclusão, que o aplicati-

3 BUTLER, Judith. Problemas de Gênero: feminismo e subversão da identidade. Trad.: Renato Aguiar. Rio de Janeiro: Civilização Brasileira, 2003. 
vo causa e vem causando, razões essas que têm levado a maioria dos perfis analisados uma distinção entre afeminados e discretos, existindo uma escolha por discrição de comportamento e não pertencimento do "meio" LGBT como forma de não parecer gay (camuflar a homossexualidade), implicando em uma possível forma da fuga de preconceitos e até mesmo represálias de cunho violento.

No entanto, ainda assim, a aceitação do sujeito se torna impossível de ser determinada, o que nos é possível são apenas possibilidades de que poderá ser aceita a partir da descrição do perfil do sujeito que está se anunciando, destacando que o mais aceito é o que se encaixa no perfil heteronormativo e, consequentemente, o menos aceito é a expressão mais íntegra da feminilidade homossexual, levando em conta um reflexo de uma cultura machista que traz as relações de poder entre os gêneros para dentro das relações sexuais masculinas, desvalorizando o gay afeminado, como socialmente desvaloriza a mulher, e colocando o ideário masculino em um pedestal, mesmo quando a relação é entre dois homens, ainda há uma disputa de gênero, empoderando aquele que se mostra ser "mais homem".

Para o percurso teórico, busquei iniciar através de um breve estudo na história das sexualidades, com o intuito de mostrar nesse artigo que, segundo Foucault, a sexualidade atua como um dispositivo de controle da vida pessoal, social e sexual dos indivíduos ${ }^{4}$. Buscando entender sobre transformações na visibilidade de representação de si mesmo, sobre a regulamentação do uso do sexo, explicando o que é o aplicativo em sua forma mais geral e explicando como o aplicativo funciona como mecanismo de fuga de uma heterossexualidade compulsória imposta pela sociedade.

\section{O que é o Grindr?}

O Grindr foi inventado pelo israelense Joel Simkhai, ainda no ano de 2009, e logo fez sucesso entre os homossexuais, bissexuais e homens à procura de sexo com outros homens. Este aplicativo de encontro pode proporcionar uma espécie de ambiente lúdico e estrutura semelhante, podemos dizer, a um jogo, através da geolocalização permitida pelo (GPS) ${ }^{5}$, onde seus usuários podem traçar suas escolhas, propiciando o ambiente perfeito para o exercício da sociabilidade, que é justamente o que busco discutir nesse tra-

\footnotetext{
FOUCAULT, M. História da sexualidade I: a vontade de saber; tradução de Maria Thereza da Costa Albuquerque e J.A. Guilhon Albuquerque. Rio de Janeiro, Edições Graal, 1997. $19803^{a}$ Edição.

O sistema de posicionamento global, mais conhecido pela sigla GPS (em inglês global positioning system), é um mecanismo de posicionamento por satélite que fornece a um aparelho receptor móvel a sua posição, assim como o horário, sob quaisquer condições atmosféricas, a qualquer momento e em qualquer lugar na Terra; desde que o receptor se encontre no campo de visão de três satélites GPS (quatro ou mais para precisão maior). https://pt.wikipedia.org/wiki/Sistema_de_posicionamento_global. Acesso em: 01 set. 2018.
} 
Nossa Gente,

Nossa História

o Ceará Republicano

balho, embasando tal colocação a partir critérios estabelecidos por Simmel, discutidas em sua obra, Questões Fundamentais da sociologia. Indivíduo e sociedade (2006).

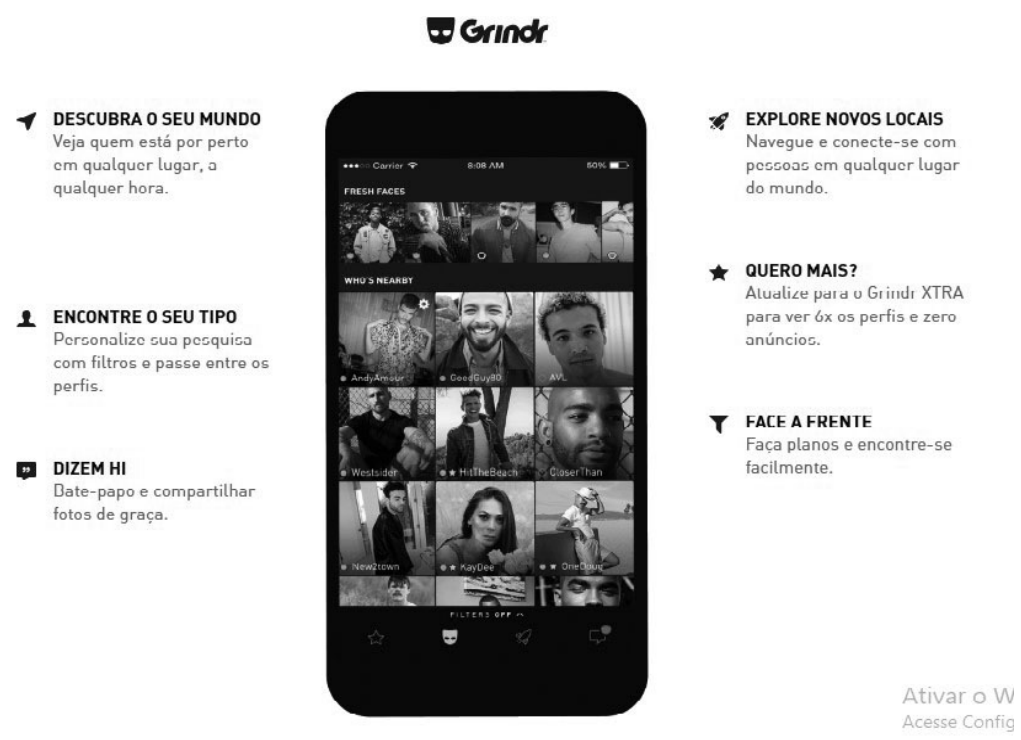

Figura 1: características do aplicativo grindr. Fonte: Disponível em https://www. 178 grindr.com/. Acesso em: 10 set. 18

Como podemos perceber na imagem anterior, o aplicativo apresenta uma estrutura que se aproxima bastante de um catálogo eletrônico, no qual apresenta um nome, embora muitas vezes fictício, idade e as fotos dos pretendentes que devem chamar a atenção e assim se destacar em meio aos demais, além de alguns exporem textos de apresentação, que muito contribuem para a escolha, e assim receber um taps como forma de interesse naquele perfil. Ainda nessa seara, a impressão é de estar em um cenário de jogo, pois ao visualizar um perfil de seu interesse o usuário pode dar um taps, que é a forma de quebrar o gelo sem ter que usar as palavras certas naquele momento, além de ter três opções de taps: amigável, atraente e interessado, no qual é possível que o dono do perfil saiba o nível de interesse.

Grindr foi lançado no mundo em 2009 e já foi baixado por mais de 10 milhões de usuários, segundo sua descrição na plataforma Play Store $e^{6}$, ao redor do mundo; só no Brasil, em 2013 contabilizava um total 500.000. Rapidamente se tornou uma das principais aplicações no mundo. No país, esse app está disponível gratuitamente nas lojas de aplicativos virtuais, além de outras aplicações com a mesma finalidade de busca de parceiros. Apesar de

\footnotetext{
É um serviço de distribuição digital de aplicativos, jogos, filmes, programas de televisão, músicas e livros, desenvolvido e operado pela Google. https://pt.wikipedia.org/wiki/Google_Play. Acesso em: 10 set. 2018.
} 
ser gratuito, o aplicativo apresenta uma versão extra, a chamada "Xtra", destinada a usuários que querem ter um número maior de opções de perfis, no entanto, para aqueles que não querem a versão paga, o aplicativo traz a opção de 100 perfis, na qual permite conversas, troca de fotos, bloqueios e até mesmo a opção por buscas personalizadas e outras finalidades. É claro que aqueles que investem na versão paga terão alguns benefícios extras. Um deles é o triplo de perfis disponíveis na tela do seu smartphone. Faz-se necessário destacar que esta aplicação só está disponível para versões android, IOS e blackbarry, sendo uma opção mais portátil e mais fácil para quase todos os usuários de dados móveis.

Para a instalação, é necessária uma conta na qual o usuário deve fornecer uma descrição e apresentar fotografias, que é forma que dará a primeira impressão aos outros usuários. Depois da instalação, ele funciona a partir de uma ferramenta de geolocalização, realizando sempre uma espécie de catalogação de sujeitos mais próximos, o que porventura facilita o contato e a consumação dos encontros, tido como uma das principais características que se destaca como diferencial em meio a outros aplicativos que funcionam quase com a mesma estratégia.

A tela inicial do aplicativo apresenta aos usuários uma espécie de mosaico, com perfis de homens com melhor proximidade, sendo apenas necessário um simples toque para iniciar um bate papo sobre eles, além de uma conversa que pode apresentar opção com trocas de fotografias, sendo que os sujeitos mais próximos ou que chamaram atenção podem ser favoritados, como uma forma de não se perderem entre os demais ou de contato mesmo.

\section{Sociabilidade homoerótica}

Ao estudarmos parte do processo histórico nacional, percebemos que a superioridade masculina sempre foi apoiada por boa parte dos sujeitos sociais, ou seja, onde o normal seria fazer parte do binarismo macho ou fêmea, homem ou mulher, resultando a ideia de heteronormativo ${ }^{8}$. A partir da análise dos perfis dos usuários, podemos perceber que ainda continua, mesmo dentro de particularidades onde pessoas se identificam com as mesmas orientações e gostos, o estigma dos processos binários de gêneros, entre "machos" e marca das "bichas", como afirma Green:

O homossexual efeminado, a bicha, atua como um indicador que diferencia seu próprio comportamento "desviado" e o com-

A versão Xtra custa $\$ 47,88$ dólares no pacote anual, o que convertido para real daria $\mathrm{R} \$ 162,14$. Essa conversão foi feita no dia 19 de novembro de 2016, com o dólar comercial custando R \$3,38.

8 Heteronormatividade (do grego hetero, «diferente», e norma, «esquadro» em latim) é um termo usado para descrever situações nas quais orientações sexuais diferentes da heterossexual são marginalizadas, ignoradas ou perseguidas por práticas sociais, crenças ou políticas. https://pt.wikipedia.org/wiki/ Heteronormatividade. Acesso em: 11 set. 2018. 
Nossa Gente,

Nossa História

o Ceará Republicano

portamento masculino "normal" de um homem "verdadeiro". Pela natureza de sua oposição binária à norma, o estereótipo social do homem "passivo" e efeminado define o homem "ativo" e "viril" 9

É necessário se destacar que essa questão de até aonde ir com sua efeminação é como uma forma de controle que busca evidenciar e ao mesmo tempo corroborar a masculinidade de heterossexuais e também dos homossexuais que carregam o status heteronormativos, ou seja, são homens que não querem se encaixar nesses padrões. Como é facilmente percebido na descrição dos perfis, que homens que se definem como homens têm maiores aceitações, conseguindo então maiores sociabilidades e podem estar em vários espaços, que muitas vezes não são permitidos para aqueles mais afeminados, como se pode observar na imagem abaixo.

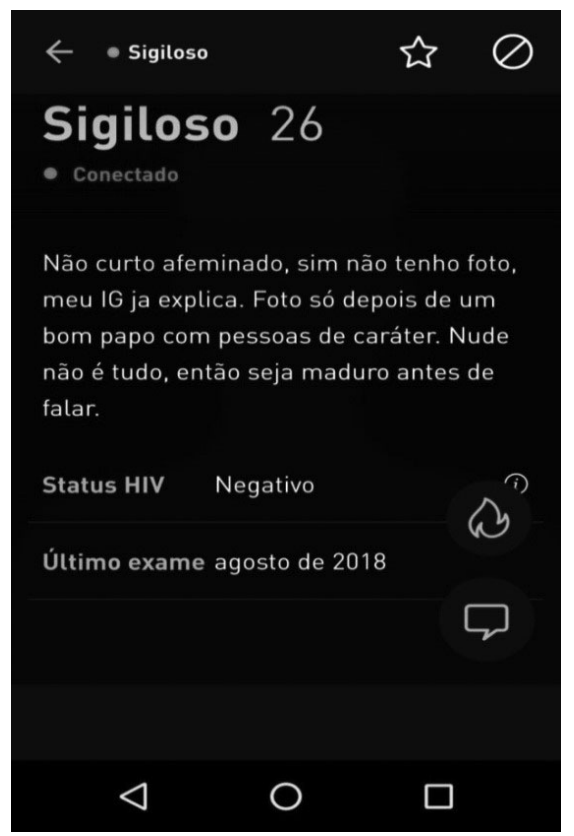

Figura 2: Descrição de um perfil. Fonte: Captura da tela retirado diretamente do aplicativo. Acesso em: 11 ago. 18

A partir de relatos informais e não gravados, alguns desses homens mantêm relações duplas, repassando a imagem de homem másculo que busca apenas diversões, alegando não ser homossexual. Para esses homens, uma maior proximidade com o masculino permite dentro de uma relação homoafetiva a possibilidade de aproximação do homem idealizado, do ser dominador, ativo, em total detrimento do sujeito passivo, dominado ou mesmo

GREEN, James N. Além do Carnaval. A homossexualidade masculina o Brasil do século XX. São Paulo: Editora UNESP, 1999. 
feminino, isso é, o ar de "normalidade" que os relacionamentos duais podem trazer, como foi possível perceber em conversas e analises de alguns perfis de usuários do aplicativo na cidade de Sobral, que sempre esteve presente no imaginário dos sujeitos que saem de suas cidades pequenas do interior em busca de melhores condições ou de estudos, por ser uma cidade de médio porte, com possibilidade de oportunidades para indivíduos que saem em busca de estudo, mas além de tudo, uma forma de liberdade, tentando fugir do preconceito social existente nas suas cidades interioranas, em decorrência do medo de assumir sua condição de gênero, no entanto, acabam migrando como forma de buscar maior aceitação, embora continuem enfrentando preconceitos. Mas Sobral, considerada metrópole em 2017 pelo IBGE, proporciona um anonimato, o que não é possibilitado nas cidades menores.

Segundo Didier Eribon, que discute essas relações de questões gays através das condições que o público homoafetivo seja atraído principalmente pela cidade e suas redes de sociabilidades; "São muitos os que procuram deixar o lugar onde nasceram e onde passaram a infância para vir se instalar em cidades mais acolhedoras [...]. Esse movimento de fuga seguramente conduz os homossexuais para a cidade grande" 10 , indivíduos estes vindos do campo e de cidades menores começam a aglutinar-se como uma forma de se verem mais amparados nesse novo emaranhado de ideias e acabam construindo novos comportamentos, identidades, além de condutas políticas e sociais na sua afirmação do ser homossexual em toda sua diversidade, se faz necessário também discutir o momento histórico do país, ou seja, marcado por uma ruptura democrática e a luta social pela ascensão como sujeitos a partir desse novo paradigma das relações homossexuais no Brasil.

\section{“Grindr: um catálogo de corpos”}

A partir dos perfis analisados podemos perceber que a busca de um parceiro está pautada no corpo perfeito, ou seja, o corpo funcionando como uma ferramenta ou recurso sexual, pelo qual a exposição imagética se adeque ao desejo do homem que busca outros homens para possíveis relações afetivas ou sexuais.

Nesse momento, é possível perceber que os corpos acabam se transformando em produtos expostos numa vitrine online e são ao mesmo tempo sexualizados e acabam se transformando em uma espécie de genérico, no qual reproduzem em seus perfis discursos e efeitos que os normalizam. Destacando que podemos situar o corpo analisado a partir de uma perspectiva

$10 \quad$ ERIBON, Didier. Reflexões sobre a questão gay. Trad. Procópio Abreu. Rio de Janeiro: Companhia de Freud, 2008. 
histórica e até cultural, compreendida por meio de uma constituição fluída que aos poucos vai se naturalizando.

É comum ouvirmos de pessoas que fazem o uso do aplicativo dizerem que "tenho mais coragem" ou "que é mais fácil" a busca de qualquer tipo de interação e envolvimento por meio do app, seja ela uma relação amorosa, casual, amigável ou somente sexual, o que ocorre na maioria das vezes, basta um simples click para iniciar uma conversa que pode levar a algo mais.

Como já foi descrito anteriormente, o Grindr é tido como uma das melhores e maiores vitrines de corpos vistos como atrativos, formas, escolhas e aptidões para se identificar com outros homens.

A audácia também não se isenta, muitos usuários que procuram apenas relações sexuais líquidas são bem diretos sobre suas intenções dentro do diálogo, buscando detalhar seu órgão sexual ou mostrando seu bumbum em local propício ao desenvolvimento da relação, se aproximando bastante da ideia "prato de carne pronto a ser devorado".

O uso constante dessa ferramenta fica monótono e repetitivo durante certo período, e quando surge novo perfil, é classificado pelos usuários por "novidade", demonstrando que o corpo na maioria das vezes se torna mercadoria que está sendo comercializada, aumentando a supervalorização de tais perfis que, por eventualidades, podem aparecer. Ressaltando também que embora o aplicativo seja com determinado nível de "discrição", ainda pode acarretar em um elevado número de perfis falsos (fake), onde são expostos dados falsos, ou até mesmo de usarem fotos de outros homens como se fossem suas, levando os usuários redobrarem o nível de cuidados e desenvolvendo metodologias que possibilitem identificar tais perfis.

\section{Considerações finais}

Com o advento do crescimento de acesso de redes sociais a partir dos dispositivos móveis, em especial smartphones, fez com que surgissem determinados tipos de aplicativos que se utilizam de recursos específicos como diferencial. Desses aplicativos, aqueles com o intuito de promover relacionamentos, que usam a tecnologia do GPS, se tornaram cada vez mais populares, e o aplicativo em questão é um dos mais populares e com mais influência dentro do público gay.

A finalidade desse estudo foi possibilitar uma análise do aplicativo como ferramenta de sociabilidade entre o público homossexual a partir da performance de seus usuários. Para concretização, foram realizadas entrevistas informais com diferentes tipos de usuários, desta forma foi possível entender a experiência de consumo do aplicativo, por meio da noção da usabilidade do 
app e principalmente, à performance e à identidade da população sobralense. De acordo com as respostas da enquete realizada entre os dias 09 e 15 de setembro através do formulário online, podemos perceber que a proposta do grindr facilita a vida afetiva dos indivíduos. Os entrevistados assinalaram que as características de maior relevância que influenciavam a combinar com alguém no app é o texto do perfil, seguido pela aparência física, ou seja, ganha mais relevância aquele usuário que em seu texto de apresentação demonstra ser mais eficiente de convencer com sua performance dentro do aplicativo, preferencialmente, através de fotos e aparência física.

Percebe-se que embora o meio virtual possa constituir uma forma para o público gay que busca um relacionamento afetivo ou sexual, fica evidente que nem todos ficam à vontade para total exposição e, principalmente, se o usuário especifica suas intenções no texto de apresentação disponível no perfil. Ressaltando que embora a intenção desse trabalho não seja generalizar os resultados obtidos pelo consumo de aplicativos nessa condição, acredita-se que as narrativas fornecidas através desse formulário, que soa necessário para fornecer o entendimento da performance e da sociabilidade neste município.

Portanto, as sociabilidades intercedidas pelos aplicativos de geolocalização apenas reforçam o anseio nos sujeitos já desejados, que se sentem oprimidos pelo conservadorismo da sociedade, como ocorreu por volta período de 1950, a exemplo dessa dificuldade enfrentada no Brasil é a obra da autora Mary Del Priore ${ }^{11}$, quando descreve os amores proibidos, tais como homens que amavam homens e mulheres que amavam mulheres sofriam preconceitos e de certa forma viviam às margens da sociedade, se escondendo ou até mesmo suprimindo certos desejos, imersos da incompreensão e sofrimento a que os homossexuais eram submetidos. Chegou-se até desenvolverem receitas para tratar aquela "inversão sexual", um dos citados pela a autora é o transplante de testículos ou a injeção de insulina como solução do "problema”, até então considerado um problema esquizofrênico ou psicossocial. Porém, com o advento das novas tecnologias e o surgimento das práticas de sociabilidades através de aplicativos, ouve uma grande mudança até os dias atuais, pois aquilo que era uma dificuldade antes, agora é facilitado pela tela dos celulares, tablets ou até mesmo computadores, ressaltando que não é apenas um acréscimo das bases sociais nem muito menos uma contestação do status quo, mas sim a busca de um grupo minoritário e capaz de romper plenamente com as construções de opressão que o fustiga. 



\title{
15. “Zé Maria Mulher”: representatividade $e$ resistência umbandista em Sobral
}

\author{
Antonio Tarciano Aragão Sousa ${ }^{1}$
}

\section{Mito fundador da Umbanda}

Ao estudar a umbanda em Sobral, percebe-se que a figura do Pai de Santo "Zé Maria Mulher" se faz presente nas memórias de muitos umbandistas e pesquisadores da religião, oferecendo uma representatividade e resistência de grande importância para a popularidade da umbanda nesta cidade. A análise das memórias produzidas pelo pai de santo foi feita sob a perspectiva da construção do processo de fundação da umbanda e da cidade de Sobral/ $\mathrm{CE}$, como veremos adiante.

Diante da história de fundação da Umbanda no Brasil, um dos questionamentos que mais é discutido pelos pesquisadores da área é o mito fundador da religião. Sá Junior estuda o mito fundador da Umbanda e percebe que a sua construção "esteve inserida em uma realidade histórica brasileira da passagem do Império à República"2. Sá Junior observa que no período de mudança do modelo social escravista para o livre, houve uma nova construção das lógicas explicativas, nas quais se criou não apenas um regime político, mas se conservou uma hierarquia social identificada pelas elites de proprietários rurais, a grande massa de escravos e uma pequena quantidade de uma classe média urbana. A partir deste período que se buscou criar uma história da nação brasileira, construindo um passado da nação através de "invenções de tradições", como aponta Hobsbawm (1984), legitimando as instituições imperiais e republicanas. Seguindo um estudo sobre a construção da nação, Hobsbawm afirma que existem mudanças no significado do conceito de nação, sendo possível distinguir três etapas: "Na primeira, de 1830 a 1880, a nação é identificada ao princípio da nacionalidade. Na segunda, de 1880 a 1918, à língua, à religião e à etnia, e, no terceiro, de 1918 a 1960, à ideia de consciência nacional"3.

Schwarcz (1993) entende que a invenção de uma história do Brasil foi inventariada nesse segundo momento, onde o conceito de raça teve um pa-

Graduando do Curso de Licenciatura em História pela Universidade Estadual Vale do Acaraú-UVA.

SÁ JUNIOR, Mario Teixeira de. A invenção do Brasil no mito fundador da Umbanda. Revista Eletrônica História em Reflexão: Vol. 6 n. 11 - UFGD - Dourados. Jan/jun. 2012, p. 2.

HOBSBAWN, Eric. Nações e nacionalismos desde 1780: programa, mito e realidade. Rio de Janeiro:

Paz e Terra, 1994, Apud, SÁ JUNIOR, Op. cit., p. 3. 
pel fundamental, servindo como base para a construção da história da "alva nação Brasil"4, onde o colonizador desempenha papel principal, enquanto negros e indígenas ocupam espaços coadjuvantes. Portanto, para a autora, o mito das três raças e a importância de cada uma na construção da "alva nação Brasil" encontra-se em todas as pesquisas que buscaram escrever uma História do Brasil, "pois a questão racial é discutida, tendo por base os conceitos de evolução, civilização e progresso, como definidores do modelo

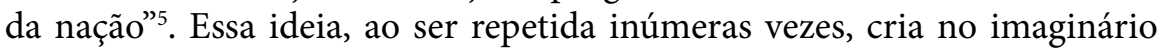
brasileiro a falsa impressão de uma unidade representativa homogênea, e se mostra como uma solução imaginária para conflitos que não podem ser resolvidos no nível da realidade.

Afirma-se que os intelectuais umbandistas, criadores do mito fundador da Umbanda, seguiram o modelo acima, buscando identificação com essa alva nação brasileira ${ }^{6}$. A invenção do mito fundador umbandista está associada a este momento histórico, e seus intelectuais utilizaram destes conceitos para se aproximar da construção da nação brasileira, propondo inventar um passado imaginário ${ }^{7}$, fazendo com que os membros dessa nação, cada qual tomando seu lugar, pudessem desenvolver o seu sentimento de pertencimento.

Sá Junior conclui que entender este mito é compreender a lógica que os 186 intelectuais umbandistas utilizaram para se aproximar e produzir diálogos com o processo histórico gerador da nação brasileira ${ }^{8}$.

Partindo para a análise da origem e seu processo de "religião autenticamente brasileira", como conceitua Emerson Giumbelli, temos como notório respaldo e poucas críticas da sociedade umbandista a figura de Zélio Fernandino de Morais. Neste caso, adquire proeminência a figura de Zélio de Moraes, cuja notoriedade se produz em torno de certo reconhecimento de seu papel de "fundador" ou de "pioneiro da Umbanda no Rio de Janeiro e arredores ${ }^{9}$.

Muitos umbandistas têm como data de origem de sua religião a manifestação da entidade Caboclo das Sete Encruzilhadas, incorporado no médium Zélio de Moraes. Este fator, segundo Artur Cesar Isaia ${ }^{10}$, contribui para a

\footnotetext{
SCHWARCZ, Lilia Moritz. O espetáculo das raças: cientistas, instituições e questão racial no Brasil 1870-1930. São Paulo: Companhia das Letras, 1993, p. 16.

SÁ JUNIOR, Mario Teixeira de, Op. cit., p. 3.

Idem.

ANDERSON, Benedict. Nação e consciência nacional. Rio de Janeiro: Ática, 1989, apud SÁ JUNIOR, Mario Teixeira de, Op. cit., p. 3,

8 SÁ JUNIOR, Mario Teixeira de, Op. cit., p. 12.

9 GIUMBELLI, Emerson. Zélio de Moraes e a origem da umbanda no Rio de Janeiro. In: SILVA, Vagner Gonçalves da (org.). Caminhos da Alma: memória afro-brasileira. São Paulo: Summus/Selo Negro Edições, 2002.

10 ISAIA, Artur Cesar. Ordenar progredindo: a obra dos intelectuais da Umbanda no Brasil da primeira metade do século XX. Anos 90 (UFRGS), Porto Alegre, v. 11, n.11, p.97-120, 1999.
} 
formação do "mito fundador" da Umbanda. A ideia do "mito fundador" da Umbanda é apresentado nas edições da Revista Espiritual de Umbanda. Na primeira edição da revista, já percebemos uma forte valorização das figuras de Zélio de Moraes e da sua filha, Zilméia de Moraes, ao Caboclo das Sete Encruzilhadas e a Tenda Nossa Senhora da Piedade ${ }^{11}$. Em algumas edições, essas figuras aparecem com maior respaldo do que em outras, mas em nenhuma há o questionamento do papel fundador para a religião.

A primeira edição, como já citado, traz uma matéria de cinco páginas com o título "Zélio Fernandino de Moraes: A primeira manifestação oficial da Umbanda" e, logo em seu primeiro parágrafo, informa que "no ano de 1908, no município de São Gonçalo, Rio de Janeiro, o jovem Zélio Fernandino de Morais (sic), então com 17 anos, recebeu a primeira manifestação oficial de Umbanda"12.

Ao longo da matéria, é relatado que no dia 15 de novembro de 1908, às 20 horas, teria sido dado início aos trabalhos espirituais da Umbanda, na Tenda Nossa Senhora de Piedade, na liderança de Zélio de Moraes. E com a chegada do patrono da Tenda, o Caboclo das Sete Encruzilhadas, anuncia que:

Vim para fundar a Umbanda no Brasil, aqui se inicia um novo culto, em que os espíritos de pretos-velhos africanos e índios nativos de nossa terra poderão trabalhar em benefício dos seus irmãos encarnados, qualquer que seja a cor, raça, credo ou posição social. A prática da caridade no sentido do amor fraterno, será a característica principal desse culto ${ }^{13}$.

Como esclarece Artur Cesar Isaia ${ }^{14}$, a data de fundação da Umbanda não seria uma mera coincidência, pois existia uma necessidade dos estudiosos da Umbanda, da primeira metade do século XX, em fixar esta data como marco de evolução, portanto ligada com data da instituição da República brasileira.

Ao concluirmos as discussões acerca do processo de fundação da Umbanda, iniciaremos análises sobre Sobral, mais precisamente sobre o conceito de "sobralidade triunfante".

\section{"Sobralidade Triunfante" e "Sobral no Plural"}

Dentro da Microrregião Norte do Ceará, Sobral é a cidade de destaque e objeto desta pesquisa. A cidade, localizada na Zona Noroeste do estado,

11 Tenda Nossa Senhora da Piedade - Considerado o primeiro templo de Umbanda, sendo fundado por Zélio de Moraes. Apud PINHEIRO, André de Oliveira. Revista Espiritual de Umbanda: Mito fundador, Tradição e Tensões no Campo Umbandista. Florianópolis: 2009, p. 50.

12 PINHEIRO, André de Oliveira, Op. cit., p. 52.

13 Idem, p. 41.

14 ISAIA, Artur Cesar. Ordenar progredindo: a obra dos intelectuais da Umbanda no Brasil da primeira metade do século XX. Anos 90 (UFRGS), Porto Alegre, v. 11, n.11, p.97-120, 1999. 
a cerca de $225 \mathrm{~km}$ de distância da capital, Fortaleza, tem, segundo o IBGE, uma área territorial de aproximadamente $2.122,297 \mathrm{~km}^{2}$. Sobral tem uma população de aproximadamente 188.233 habitantes. Porém, o próprio Instituto já estimou que, em 2016, a cidade possuía uma população de aproximadamente 203.682 habitantes. O município possui a segunda maior economia do interior do Ceará, ficando atrás apenas de Juazeiro do Norte ${ }^{15}$.

Partindo da gênese do município e do seu desenvolvimento, identifica-se o processo histórico de mudança da "Fazenda Caiçara (1742) à condição de Villa Distincta e Real de Sobral (1773), chegando à categoria de Fidelíssima Cidade Januária do Acaraú (1841), para depois ser somente Sobral (1842)”16.

Ao se delimitar um território, podemos assim iniciar análises sobre aquele local, e conseguimos perceber na população os reflexos do sentimento de pertencimento, além de identificarmos assim, características próprias daquele território e diferenciações sobre outros. Essas características são geradas por meio da construção de um discurso que estabelece uma identidade coletiva. Esse processo, como narra Freitas (2000), é muito comum, e não apenas observado no Ceará, mas em vários outros estados e regiões. A construção desses discursos de identidade coletiva pode variar a partir dos sujeitos sociais que a narram, ou de uma identificação em específico. Freitas (2005) direciona seu olhar para a construção da identidade sobralense a par188 tir da elite do município e a sua elaboração discursiva que tem a pretensão de caracterizar e representar cada cidadão sobralense.

Apesar de ser perceptível a representação da elite da cidade nas relações de poder e na construção de discursos afirmativos, Freitas (2000) aponta que esta elite não é homogênea e que dentro deste âmbito social existem disputas por posições privilegiadas, surgindo "autoridades" sobre autoridades. Nota-se, a partir dessa percepção, que essa representatividade da elite municipal é escorregadia como qualquer outra e necessita ser analisada a partir do seu tempo histórico. Este trabalho segue analisando a construção e a naturalização do discurso sobre uma "sobralidade triunfante" ${ }^{17}$, considerando como elite os sujeitos históricos propostos pelo autor, focando naqueles que obtiveram importantes cargos hierárquicos eclesiásticos, jornalísticos, intelectuais e acadêmicos. Freitas (2003) conclui que o termo "sobralidade" funciona como um "designador rígido" que não se modifica e perdura, e que identifica, de forma genérica, cada cidadão sobralense, sendo utilizada pelo poder público como um divisor nítido municipal, principalmente em relação a Fortaleza. Portanto, todo sobralense seria igual diante desse imaginário

Dados retirados do IBGE. Censo de 2016.

16 SILVA JÚNIOR, Agenor Soares e. Cidades Sagradas. Da "Roma cearense" a "Jerusalém sertaneja": A Igreja Católica e o desenvolvimento urbano no Ceará (1870-1920) Sobral e Juazeiro do Norte. Sobral: Edições ECOA, 2015, p. 187.

17 FREITAS, Nilson Almino de. Sobral Opulência e Tradição. Sobral: Edições UVA, 2000. p. 115. 
de "identidade", e este fator é utilizado como justificativa nos documentos do Tombamento do Patrimônio Histórico de Sobral ${ }^{18}$.

Estes processos históricos contribuíram para a construção do discurso de uma "sobralidade triunfante" pela elite sobralense, e como explica Freitas (2003), esta camada social utiliza deste discurso como padrão de todas as categorias sociais da cidade. Porém, esta sobralidade é representativa de uma camada social, a elite. Percebemos que a narrativa de origem se desenvolve utilizando as riquezas dos fazendeiros e comerciantes, e que a partir dessa narrativa outras surgem demonstrando a riqueza e revelando fases culturais econômicas significativas de Sobral ${ }^{19}$.

Através da discordância do discurso da "sobralidade triunfante", Oliveira e Freitas (2010) propõem a construção de uma narrativa histórica que abrangesse além do cidadão triunfante o "cidadão comum" ${ }^{20}$. Diante disso, houve a produção em 2010 do filme "Sobral no Plural". Este filme foi apresentado no "II Visualidades" e traz uma série de entrevistas realizadas com diversos moradores de Sobral. O Visualidades é um evento organizado pelo Laboratório das Memórias e das Práticas Cotidianas - Labome, laboratório vinculado ao Curso de Ciências Sociais da UVA. Esse evento incentiva a produção de vídeos e exposições que relacionem pesquisa e imagem. O filme foi produzido com base nos arquivos audiovisuais do Labome.

Entende-se que não se pode pensar a cidade como uma homogeneidade cultural $^{21}$, pois ela apresenta-se múltipla e variada. Os autores declaram que a história de Sobral não se apresenta de forma didática como se apresenta na política de monumentalização, pois a cidade não se define apenas das opulências. O filme conta a história daqueles que supostamente sustentaram a ideia de "sobralidade triunfante", que são representados pela "história oficial" como membros que preservam a tradição da cidade. Uma das principais contribuições do filme é um estudo sobre os bairros sobralenses. Diversos moradores puderam contar a sua história e dos seus bairros, demonstrando a diversidade sociocultural presente no município. Diante de uma série de entrevistas realizadas, será priorizada neste momento a discussão da relação entre Sobral e a Igreja Católica e a falsa afirmativa de que a cidade é exclusivamente católica ${ }^{22}$.

Silva Júnior (2010) aponta que para os estudiosos da história de Sobral existe uma concordância quanto à gênese do povoamento, que estaria na doação de terras, no século XVIII, pelo capitão Antônio Rodrigues Maga-

20 FREITAS Nilson Almino de; OLIVEIRA, Paulo Passos de. O filme e o arquivo: contexto e concepção do documentário "Sobral no plural". 2010, p. 88.

${ }_{21} \quad$ Id. Ibid., p. 87.

22 FREITAS Nilson Almino de; OLIVEIRA, Paulo Passos de, Op. cit., p. 87. 
lhães e sua mulher, Quitéria Marques de Jesus, os donos da fazenda Caiçara, para a construção de uma igreja matriz que servisse de sede para o Curato da ribeira do Acaraú. Esse, para os estudiosos da história da cidade, seria o marco inicial do desenvolvimento da fazenda e do surgimento de um povoado ao redor da igreja. $\mathrm{O}$ autor segue descrevendo as relações estabelecidas entre a cidade e a Igreja Católica, e aponta que a cidade se desenvolveu ao redor das igrejas, sendo que inúmeras ruas foram traçadas a partir desse fator. Silva Júnior (2010) informa que a Matriz da cidade seria a "pedra angular" e que esta igreja seria como o rio Acaraú e a serra da Meruoca, ou seja, um ponto de orientação espacial. Por fim, o autor afirma que este processo histórico gerou o imaginário sobralense de uma cidade sagrada, uma cidade católica.

Freitas e Oliveira (2010) concordam com o imaginário de uma cidade presa à religião católica, mas apontam que o município não parte de uma homogeneidade cultural e demonstram a forte presença da Igreja Protestante na cidade, além de ser uma cidade formada também por umbandistas e candomblecistas. Em seu filme, os pesquisadores entrevistaram o pai-desanto Pai Padrinho, morador do bairro Dom Expedito, buscando apresentar a diversidade religiosa sobralense. Pai Padrinho relata que existe uma forte aproximação do seu bairro com seu terreiro, sendo muito querido pela população local, e afirma que nunca sofreu preconceito por ser umbandista. Ao trazer este diálogo com Pai Padrinho, Oliveira e Freitas (2010) possibilitam que se perceba uma cidade múltipla, com muitas figuras que não são prestigiadas pelo imaginário da "sobralidade triunfante", mas que dentro dos diversos bairros pesquisados têm suas memórias construídas e preservadas.

Iniciaremos agora a percepção sobre o umbandista mais conhecido de Sobral, percebendo que mesmo com a construção do imaginário de uma cidade católica, trouxe a resistência e a representatividade umbandista para a cidade.

\section{As memórias e a representatividade de Zé Maria Mulher}

José Maria Lima, popularmente conhecido como Zé Maria Mulher, paide-santo de Umbanda, líder espiritual do Terreiro Ogum Marinho, é uma das figuras mais populares da Umbanda sobralense. Não se sabe se ele foi o primeiro umbandista da cidade, porém, a popularidade que Zé Maria Mulher trouxe para a Umbanda em Sobral é perceptível a todos que adentrarem não apenas em ambientes de pesquisas relacionadas à religião, mas para a grande maioria de umbandistas da cidade. Para os entrevistados ao longo de toda essa pesquisa, a figura do pai-de-santo é sempre lembrada como pioneira na popularização da religião dentro da cidade, além de deixar para a cidade uma grande quantidade de filhos de santos. Um breve estudo sobre sua memória nos possibilita iniciar um reconhecimento da Umbanda em Sobral. 


\begin{abstract}
Zé Maria chega em Sobral em novembro de cinquenta e seis e não podendo alojar-se na casa de sua irmã, aluga uma pequena casinha na rua do meio, onde dá início as suas atividades religiosas para se tornar o umbandista mais conhecido e respeitado da cidade de Sobral. [...] A maioria das pessoas habitantes da cidade há algum tempo, já ouviram falar de Zé Maria Mulher. No decorrer da pesquisa como estratégia para confirmar a popularidade deste pai-de-santo, sempre fazia comentários com amigos e conhecidos a seu respeito, se não o conheciam já haviam ouvido falar. Pegar um táxi ou mototáxi e pedir para ir ao terreiro do Zé Maria Mulher, não precisa explicar o endereço" ${ }^{23}$.
\end{abstract}

O antropólogo Gleidson Vieira dos Santos, em seu trabalho A PombaGira no imaginário das prostitutas, realizado na cidade de Sobral, traz em sua escrita etnográfica a transcrição de uma entrevista realizada pelo autor com Zé Maria Mulher. Santos (2006) indica a necessidade da "cristalização de informações que até hoje permanecem na oralidade" ${ }^{24}$. Após percebemos a força do discurso sobre a "sobralidade triunfante", o registro das memórias daqueles que não aparecem neste discurso pode nos levar a imaginar a história de Sobral a partir de novas perspectivas. Percebe-se que existe uma forte presença da Umbanda em Sobral, porém, a presença do discurso triunfante do município e a sua forte relação com a Igreja Católica anulam a presença desta religião em nosso território. Porém, percebe-se ao adentrar nas pesquisas sobre esta temática que existe em nosso município uma grande quantidade de terreiros de Umbanda, e que se necessita desconstruir o falso imaginário de uma Sobral unicamente católica, pois a partir dessa perspectiva é que se fundamenta o preconceito religioso sofrido e observado nos terreiros de Umbanda.

A partir dessa perspectiva e da análise das entrevistas realizadas por Santos (2006), inicia-se um olhar sobre a trajetória de vida de Zé Maria $\mathrm{Mu}$ lher, assim é possível que haja uma quebra do discurso sobre uma sociedade homogênea e iniciem-se análises sobre os reflexos da multiplicidade social e cultural encontrada no município. Em sua primeira entrevista, Zé Maria Mulher relata como a sua mediunidade era "confundida" com doenças e como, por isso, teve sua infância conturbada.

- Meu filho, quando no início, quando tinha cinco anos eu era doente, eu comecei a sentir coisas e a minha raça pensava que

23 SANTOS, Francisco Gleidson Vieira dos. A Pomba-Gira no imaginário das prostitutas. Monografia (Graduação em Ciências Sociais) Universidade Estadual Vale do Acaraú -UVA. Sobral, 2006, pp.3334.

24 QUEIROZ, Maria Isaura Pereira. Relatos Orais: do "indizivel" ao "dizivel”. In: SIMSON, Olga de Moraes Von (org.). Experimentos com Histórias de vidas: Itália-Brasil. São Paulo: Vértice, Editora Revista dos Tribunais, 1988. apud. SANTOS, Op. cit., p. 31 
eu ia dar era ataque de epilepsia. Dias de segunda-feira, de terça, de quinta que eu sentia as coisas veio uma prima minha, prima minha não, prima da minha mãe que foi embora há um tempão e casada e quando voltou foi só e ganhou muito e quando ela chegou nos dias da minha doença que eu sentia as coisas e ela diz:

- Já sei, Chaguinha não dá este remédio que esse menino não tem doença não.

- Mulher como é que tu sabe o que este menino tem?

- Este menino tem espírito.

- Pelo amor de Deus, mais ante(sic) uma boa morte. (Entrevista cedida em 2001 apud. SANTOS, 2006).

Aos cinco anos, Zé Maria relata que sua mãe, convencida pela prima, o levou em uma sessão com uma "macumbeira", expressão utilizada pelo paide-santo, em Camocim. Ao iniciar a sessão, a "entidade", não identificada na entrevista, relata que não havia nenhuma doença na vida do menino, mas que a criança nascera com a mediunidade de incorporação, opondo-se em fazer qualquer trabalho contra isso, indicando apenas alguns banhos que a criança deveria tomar. Estes banhos, segundo Zé Maria Mulher, ajudaramno por dois anos, pois quando ele completou a idade de sete anos, sua mediunidade retornou com características mais fortes.

\begin{abstract}
Aí passei dois anos numa legal quando foi num dia quando eu completei sete anos aí voltou tudo de novo muito mais forte, ninguém mandava mais na minha vida, tá (sic) entendendo? A noite alguém vinha a mim não sei se sonhando e dizia assim: eu sou fulana, o meu... aí começava a cantar, começava a cantar e me levava noutra parte que não era o meu lugar, você tá entendendo né? E cantava, no outro dia eu cantava aquela música, aquela doutrina todinha pra minha avó ou pra alguém da minha confiança. (Entrevista cedida em 2001 apud. SANTOS, 2006).
\end{abstract}

A partir desta idade, Zé Maria Mulher relata que iniciou seus trabalhos mediúnicos e, às vezes, utilizava do dinheiro da mãe para a compra de velas. Ele continua relatando que também conseguia dinheiro atendendo espiritualmente algumas pessoas, logo ficando muito conhecido.

Sua mãe nunca aceitou a sua relação com a Umbanda, afirmou o entrevistado, e sempre que descobria seus trabalhos mediúnicos, batia nele, quebrava as suas velas e o proibia de ir ao pé de jurema ${ }^{25}$. A relação com sua mãe se agravou quando ele completou dez anos, pois começou a ser perseguido pela Igreja e pela polícia de sua cidade, Massapê. Aos onze anos, sua mãe não aguentando a perseguição que estavam sofrendo, mandou o filho ir embora.

25 Jurema - Árvore muito comum na região nordestina e considerada sagrada por muitas religiões de matrizes africanas e afro-ameríndias. 
Fui pra Fortaleza, já perseguido morando em Massapé que lá era perseguido pelo padre Neo e pela polícia porque eu trabalhava, ai minha mãe me butou(sic) pra Fortaleza pra casa de uma irmã, a Teresinha. Quando eu cheguei lá comecei com amizade com uma pessoa e a pessoa [...] andava nas macumba e fez uma operação de vesícula e quando, pediu pra eu tomar conta, dar de comer o cachorro dela e o gato quando ela chegou eu tinha afirmado uns ponto pro mestre Carlo da Jurema pra ela ser bem sucedida na operação. Quando ela chegou sete hora da noite e foi dormir quando foi de manhã que ela foi no quintal viu os ponto ai quase morre. - Zezim como é que você faz uma coisa dessa eu deixei você tomar conta da minha casa, você deixou alguém entrar pra acender vela. - Lurdinha quem acendeu os ponto fui eu pedindo misericórdia, cura pra você, pra você voltar pra dentro de casa. - Ô Zezim você entende disso, você entende? - entendo, eu trabalho. - pois pronto quando eu melhorar nós vamos numa macumba. Fui numa macumba quando cheguei lá [...] o caboclo me botou pra fora que eu era criança [...] eu me arrependi da hora que eu nasci de ter ido embora pra Fortaleza e ta(sic) ali e ter desobedecido a minha mãe, ai no camim(sic) eu chorando ela, - Não Zezim num(sic) chore não que quando for daqui a oito dias nós vamos numa macumba de uma pessoa boa. Ai eu tava vendo a hora passar o mês todim(sic) e não chegar esse domingo [...] levando ela na bicicleta quando eu cheguei a macumbeira tava sentada na área, na área não no jardim da casa dela já trajada de macumba, ela - Ei minha filha entre, como é que cê(sic) ta(sic)? Andava me butando(sic) chifre por ai, ela disse - Não madrinha eu fiz foi uma operação, ai levantou uma peça, levantou a outra e mostrou. - E essa coisinha linda aqui quem é? - mora de frente a minha casa, madrinha ele num trabalha, eu vi ele trabalhando. - trabalha? - trabalha. Pronto ai quando a macumba começou ela trabalhou quando ela despertou ai foi me botar pra trabalhar. Primeira vez que eu trabalhei em Fortaleza, enquanto ela tava trabalhando eu passei mal com agonia de corrente e ela veio pegou na minha cabeça, passou uma limpeza e eu melhorei [...] Ela me botou pra trabalhar, eu recebi o meu guia que era meu pai de cabeça e por coincidência o meu guia era o guia dela e quando ele chegou disse que queria se sentar na cadeira dele e todo mundo ficou em dúvida, ai ele disse na frente dela e na frente do cambone que era marido dela,- Meu filho essa cadeira é a minha eu só to ocupando outra matéria, eu sou o Rei dos Índios, quero me sentar me dê meu charuto. Minha filha você, faz oito ano que eu venho na sua cabeça e que não venho em médio nenhum, vim trazer o meu filho pra você terminar de faze(sic). Ai ela foi se ajoelhou nos pés dele, se deitou e ele saravou ela e ela beijou e se agarrava muito chorando. Ai então começou tudo! Ai eu passei quatro ano lá sendo uma pessoa muito importante, tanto pra ela e o marido dela como o povo, mas os filho-de-santo só faltava me matar. Quando eu tava trabalhando até furada de alfinete coisaro(sic) e de cigarro pra saber se eu tava atuado. 
Ai morreu uma filha dela com onze mês de casada morreu de ataque eclampe(sic) e ela se desgostou, se decepcionou, disse que eu viesse me embora pra minha terra que ela ia embora pra Brejo Santo. Ai eu vim me embora, isso novembro de cinquenta e seis, passei doze dias na casa da minha irmã Nilza, minha irmã disse que ia mandar uma carta pra minha mãe no Massapê pra minha mãe vim me buscar que num(sic) queria macumbeiro na casa dela não"26.

A utilização da última transcrição, sendo esta por completo, se faz necessária para uma noção de como eram estabelecidas as relações entre as entidades e os umbandistas, pois como a entrevista nos revela, a entidade Rei dos Índios foi o propulsor da permanência de Zé Maria Mulher na própria Umbanda. Após ser expulso da casa de sua irmã, já que ela não aceitava sua religião, Zé Maria Mulher buscou uma residência na cidade de Sobral, onde se instalou e iniciou seu atendimento espiritual. O pai-de-santo afirma que ao chegar em Sobral, com catorze anos, começou a procurar casa para alugar, localizando uma na "Rua do Meio", onde começou a trabalhar atendendo clientes e soltando baralho.

Depois da morte de sua mãe, aos dezesseis anos, Zé Maria Mulher, já havendo deixado seu antigo endereço, registrou seu terreiro na rua Mont'Alverne, no bairro do Campo dos Velhos. Torna-se popularmente lembrado, não apenas pela comunidade umbandista sobralense, mas por uma grande maioria dos cidadãos sobralenses. Zé Maria Mulher morreu em 2008, mas suas giras deixaram de ocorrer, gradativamente, a partir dos anos 2000.

Abaixo, segue uma fotografia que mostra a figura de Zé Maria Mulher, ao centro da imagem, incorporado com a Pomba-Gira Cigana, e acompanhado de assistentes.

${ }_{26}$ José Maria Lima (Zé Maria Mulher). Pai de Santo. Entrevista concedida a Gleidson Vieira dos Santos. In: SANTOS, Op. cit., p. 35-36. 


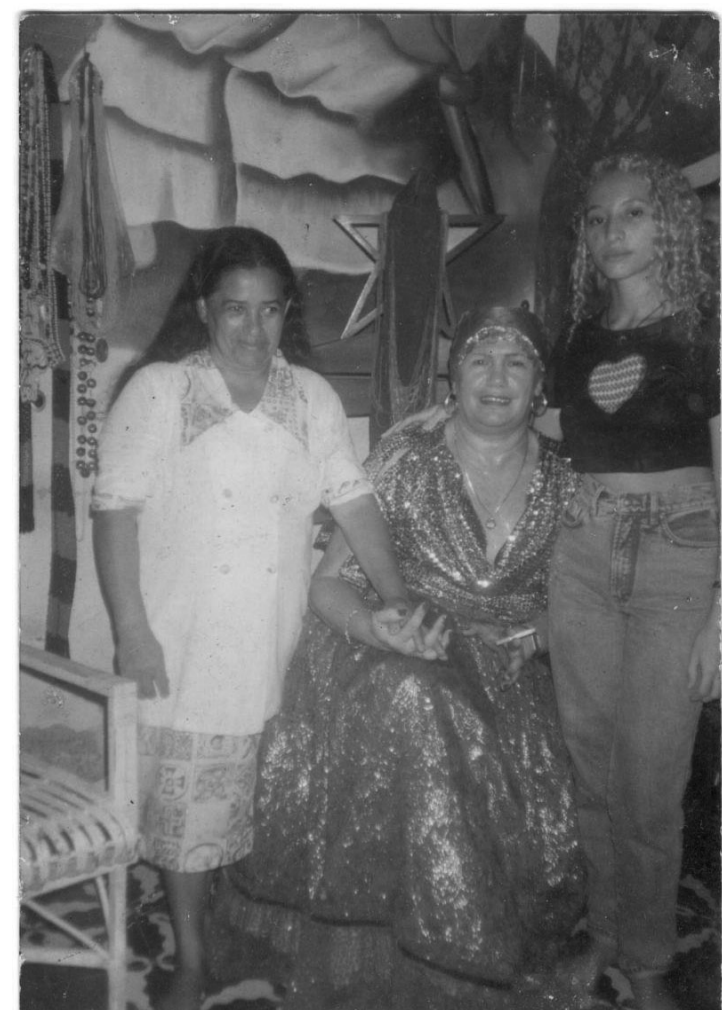

Figura 01 - Zé Maria Mulher e assistentes. Fonte: Arquivo do autor.

Hoje se percebe que a propagação do discurso sobre a "sobralidade triunfante" trouxe para Sobral uma falsa identidade de cidade unicamente católica, tendo excluído as diversas representatividades religiosas presentes na cidade, sobretudo a Umbanda. Por fim, considera-se que mesmo diante de toda dificuldade representativa, a figura do Pai-de-Santo Zé Maria Mulher trouxe reconhecimento para a religião e construiu, dentro de Sobral, uma imagem constantemente lembrada pela comunidade umbandistas e por uma parcela significativa de cidadãos sobralenses. 



\title{
16. "Mas digo uma coisa, não é a gente que cura, mas sim Deus". Memórias de benzedeiras em Alcântaras-CE
}

\author{
Maria Deiziane Lino ${ }^{1}$
}

O presente texto tem como objetivo analisar as representações de terapeutas populares, popularmente conhecidas com benzedeiras, tendo em vistas suas práticas dedicadas ao tratamento e à cura de enfermidades, conforme se dá no município de Alcântaras - Ceará, comentando sobre a prática e o fazer destas mulheres. Na premissa de que as mulheres benzedeiras, como importantes personagens da cultura popular, detêm de um conhecimento passado de geração a geração e que se perpetua até os dias atuais, nossa análise também visa ressaltar alguns aspectos referentes à apreensão e transmissão deste saber. Por meio de entrevistas estruturadas, onde foi possível constatar que as benzedeiras, ao mesmo tempo em que constituem uma identidade coletiva, tendem a apresentar formas bastante individualizadas no seu fazer. Enfim, com essa pesquisa pretende-se colaborar com a história da localidade de Alcântaras e, por consequência, com a história do Ceará de forma geral, já que estudar a história das benzedeiras é mergulhar em nossas raízes culturais mais genuínas. No mais, cabe agora conhecer o pouco deste estudo.

\section{Benzedeiras em Alcântaras - Ceará}

Fruto de uma pesquisa de monografia, o presente texto fala sobre a história de vida e os rituais de cura das benzedeiras do município de Alcântaras, mas especificamente das comunidades de zona rural Sítio Belém e Sítio Milagre, para se entender quem são estas mulheres benzedeiras, seus rituais de cura e reza que exercem no meio social a que pertencem, investigando as memórias de três benzedeiras das localidades acima citadas. As senhoras Maria Ferreira Lino, Maria do Livramento de Menezes e Raimunda Marciano da Costa são as protagonistas desta narrativa, que usam de um mistério e uma simplicidade que jamais serão explicados. Para tanto, não podemos deixar de frisar a contribuição de autores como Elda Rizzo de Oliveira, Manuel Alberto Quintana e Mayre Grayce Souza.

Graduanda do Curso de História da Universidade Estadual Vale do Acaraú-UVA. Bolsista do Programa de Educação Tutorial - PET. 
Neste sentido, torna-se fundamental entender o lugar de fala destas mulheres, os artifícios que utilizam para fazer da benzeção um instrumento de cura. Para tanto, em alguns lugares, dependendo da região, as mulheres que detêm esta prática cultural e social e que praticam este ofício são conhecidas como "rezadeiras", "curandeiras" e "benzedeiras", como é o caso das comunidades de Sítio Belém e Sítio Milagre, do município de Alcântaras - CE. Sendo assim, optamos pelo uso desta última, tendo em vista que é o termo mais utilizado tanto pelas próprias mulheres da cura - uma vez que elas mesmas se definem assim -, como pela comunidade, em sua grande maioria.

Nessa perspectiva, pretendemos historicizar as vicissitudes destas mulheres que são presenças significativas em meio à sociedade, visando mostrar que a história das benzedeiras pode e deve ser entendida para além de suas ações, sendo também a história das mulheres em geral.

No entanto, quando abordamos alguma questão sobre benzeção, práticas curativas, logo o tema é associado às questões religiosas e de uma medicina alternativa de cura. Por outro lado, é muito difícil pensar nas benzedeiras e na sua prática como fator social e culturalmente construído, como um fator humano, e mais difícil ainda é perceber e pensar toda a historicidade por trás do processo de apreensão e transmissão deste saber da cura.

\section{As Benzedeiras: entre o dom e seu ofício}

Nesse instante, o foco se desdobra ao ofício das benzedeiras, um exercício constituído através da oralidade que visa absorver as falas como forma de entendimento sobre as práticas de reza e cura realizada por essas senhoras durante um bom período de suas vidas. Assim, foi possível identificar elementos denominados dentro da pesquisa de linhas de vida, ou linhas de referências culturais.

Sendo possível compreender que tal apreensão e transmissão deste conhecimento consistem em diferentes aspectos que vai desde o familiar ao sobrenatural. Desta forma, há quem diga que aprendeu com seus familiares, que já detinham tal conhecimento; ao contrário, têm aquelas que dizem ter aprendido e iniciado o conhecimento da reza através de outras pessoas que não são seus parentes, mantendo o discurso de que muito que aprendeu foi por curiosidade, ou seja, vendo os outros fazendo. Contudo, cabe aqui salientar que aquelas benzedeiras que tinham maior prestígio social no seu ofício, geralmente atribuíam sua aprendizagem a uma espécie de experiência mística, um "dom divino", afirmando terem aprendido sozinhas.

Desta forma, teremos pelo menos duas formas principais de inserção e apreensão desses sujeitos históricos no universo da benzeção, ocorrendo principalmente pelos laços de parentesco, em geral por avós, mães, tias e ou- 
tros. A outra categoria está vinculada a uma espécie de "dom divino", ou seja, por mais que elas relatem que apreenderam as rezas com seus familiares, que boa parte das suas experiências vem dos seus antepassados, elas sempre vão associar sua prática ao sobrenatural, afirmando ter recebido o "dom de cura, na premissa de que não é qualquer pessoa que pode ser um benzedor e uma benzedeira.

Corroborando com o que foi inferido acima, temos Alberto Quintana, que a partir dos seus estudos acerca da aprendizagem da prática da benzedura diz:

A formação da benzedeira depende de uma aprendizagem assistemática, mas que, a rigor, pode ser dividida em dois tipos: aquela que é resultado de uma experiência sobrenatural e a que é conseqüência de um processo imitativo em relação a um mestre $^{2}$.

Portanto, e a partir de Quintana, temos aqui duas formas principais de inserção destas mulheres no universo da benzeção, processo descrito por Quintana como "imitativo" (adquirido) e "sobrenatural" (recebido).

Dona Maria Ferreira, mais conhecida com Maria Lázaro, quando questionada sobre com quem e como aprendeu a benzer relata:

Aprendi uma parte com a minha mãe, outra parte aprendi ouvindo as pessoas rezar, e outras foi que me ensinaram né, uma benzedeira me ensinou, mas aprendi mais vendo as pessoas rezarem, porque a benzedeira já rezava para a gente aprender e eu aprendi assim, agora tinha algumas reza que eu não aprendi porque não era para eu aprender porque a reza é para curar né, e como é que a gente reza com o demônio. Pois é, foi ouvindo, ouvia as pessoas rezando, e aprendi melhor vendo as pessoas rezando, aprendi bastante coisa, mais eu não usava rezar não, rezei por necessidade, eu não tinha fé não. Minha mãe também me ensinou uma oração que é a de quebrante.

Diante deste relato inicial, peço que ela fale de quando começou a benzer e ela diz:

Rezei por necessidade, a primeira vez que rezei, sei que aqui acolá eu rezava pensando um dia eu preciso, sempre lembrando, relembrando as rezas para que se precisasse um dia eu não me entrapalhar, aí foi assim, eu tive precisão porque eu não sei se minha reza era melhor do que a da mulher ou era a fé, a mulher

2 QUINTANA, Alberto Manuel. A ciência da benzedura: mau olhado, simpatias e uma pitada de psicanálise, Bauru, SP: EDUSC, 1999, p. 53-55. 
era rezadeira, aí a mocinha minha desmantelou uma veia aqui da coxa, do pé da virilha pra cá, quando bastasse ela fazer uma viagizinha para Alcântara, a coxa inchava chega ficava vermelha, vermelha ai eu mandava a mulher rezar, para eu não rezar, mas sempre com cuidado nas minhas rezas, mas sem fé de jeito nenhum, aí quando foi um dia esta mulher rezou, rezou, rezou, a menina fez uma viagem tornou adoecer de novo, aí eu sabe menina desde hoje eu vou rezar, eu vou rezar, rezei, quando foi, rezei né, quando ela fez uma viagem não sentiu nada. E eu sem fé a primeira vez que eu rezei né, eu senti que a menina tinha ficado boa, pronto, e tá boa, e num é assim que a pessoa manda se operar, manda fazer isso, manda fazer aquilo de abestado né. Ai eu rezei fé em Deus e nossa Senhora e ela ficou boa $[. . .]^{3}$.

Já Dona Raimunda Marciano, outra benzedeira da localidade, quando questionada sobre quando começou a praticar a benzeção diz o seguinte:

Aprendi a benzer com 12 anos, foi sozinha ninguém me ensinou, aprendi com livre espontânea vontade. Minha mãe já rezava, tem muita gente que sabe, só que as pessoas tem um dom, já é um dom que Deus já dá para aquela pessoa rezar. É um dom que a pessoa tem. A primeira reza que eu rezei, eu, assim, eu aprendia reza mas eu não rezava em ninguém. A primeira reza que rezei foi naquele Vaguim da comadre Hosana, primeira reza para quebrante. Aí eu rezava, eu sabia mas eu não rezava em ninguém.

A partir dos relatos acima, é possível inferir que há uma diferença quanto ao começo destas mulheres no mundo da benzeção. Elda Rizzo, ao trabalhar sobre estas questões, vai nos dizer: "[...] no momento inicial que move a benzedeira em busca de um conhecimento que lhe possibilite o exercício do seu ofício, o despertar para a benzeção é o "chamamento", isto é, quando ela se descobre vocacionada para praticar o bem" ${ }^{4}$.

No entanto, na fala de Dona Maria Lázaro, seu processo inicial no ofício da benzedura se dá por conta de uma necessidade pessoal e familiar, ou seja, no seu caso, tudo começou no propósito de curar seus próprios filhos. Ao contrário de Dona Raimunda Marciano, que traz o ofício da benzedura como um dom que vem de Deus. Para tanto e diante da fala de Dona Raimunda, surge o seguinte questionamento: mas que dom é este que precisa ser aprendido? E, por vezes, num longo espaço de tempo? Pois se paramos para observar a fala de Dona Raimunda, ela vai dizer que começou a aprender com doze anos, mais só realizará sua primeira ação aos vinte anos.

Maria Ferreira Lino conhecida por (Maria Lázaro), 73 anos, aposentada. Entrevista realizada pela autora em 07 de Maio de 2017. Sítio Belém, Alcântaras-CE.

4 OLIVEIRA, Elda Rizzo de. Doença, Cura e Benzedura: um estudo sobre o ofício da Benzedura em campinas, 1983 p. 178. 
Contudo, ainda que este aprendiz comece a aprender as rezas em idade precoce, seu reconhecimento só virá na sua fase adulta, pois tudo parte da experiência. Ainda nesta linha de raciocínio, a aprendizagem se dá através da memorização das palavras, que em meio a tantas explicações pode ser entendida como uma estratégia das famílias mais pobres que, em meio às dificuldades e não podendo registrar tais orações, mantinham a preocupação com a memorização, mantendo assim a tradição da oralidade.

Portanto, é uma prática que não se dá num curto intervalo de tempo e os ensinamentos partiram de outras experiências, que por sua vez também vieram de outras, e não somente de outras experiências, mas de outras culturas, que lhes serviram para organizar e reorganizar a sua própria prática. Não querendo aqui de forma algum contradizer a fala destas mulheres, longe disto. No entanto, chamemos a atenção para aquilo que se tem como um "dom", pois embora elas se coloquem como portadoras de um "dom", de fato, na historicidade do processo, elas foram apreender como se fazia, elas não saíram benzendo de qualquer maneira, elas não inventaram suas rezas, considerando que elas podem até ter readaptado algumas, mas muitas das suas orações elas aprenderam com alguém que já praticava, se não aprenderam, como deixa claro Dona Raimunda, mas conviveram desde sua infância com um familiar que já praticava a benzeção.

Portanto, é preciso deixar claro que tudo parte de uma construção humana e social, embora elas se digam dotadas de um "dom divino", elas passaram por todo um processo de aprendizagem, foi aos poucos que elas foram se dando conta e tendo conhecimento das diversas rezas, males, utensílios e ervas utilizadas em prol da cura dos males e enfermidades.

Outro importante ponto para se compreender o universo destas mulheres é saber que a prática da benzedura vai se constituindo com algumas características. Para aqueles que desejam exercer tal ofício, precisam acreditar no que estão se propondo a fazer, pois é nisto que consiste a prática da benzedura; não se negar de forma alguma a socorrer a quem necessitar, independente de quem quer que seja; independente das crenças e religião que seguem; nunca cobrar pelo serviço, pois para as benzedeiras não é algo delas, e sim algo dado por Deus.

Este aspecto é unânime nas suas falas, o serviço jamais deverá ser cobrado. A justificativa para tal ênfase é que elas são apenas intermediadoras, ou seja, é um "dom" lhes dado para ajudar aqueles que sofrem de alguma enfermidade, logo, "é um dom que não lhes pertence".

No entanto, e apesar de todo o discurso da gratuidade, nada impede que elas ganhem alguns agrados. Como bem nos relata Dona Maria Lázaro: mas as pessoas sempre dão alguma coisinha, me lembro que 
rezei numa pessoa né, aí já fazia dias, quando cuidei a pessoa chegou aqui com uma rede embrulhada pra mim, me agradecendo que tinha ficado bom.

Noutra situação, e ainda que haja diferenças quanto à prática de cada uma destas mulheres, elas se declaram católicas, rezam e devotam os santos populares, que segundo Grayce Mayre: "No ritual da benzeção, através das rezas, elas invocam os poderes curativos dos santos com a convicção de que estes irão atender os seus pedidos, pondo fim àquelas dores que maltratam os seus clientes" ". E a partir de Márcia Moisés Ribeiro, uma das referências de Grayce Mayre, o poder curativo dos santos "é uma herança do catolicismo medieval - ou mesmo antes disso - e muito difundido no Brasil durante o período colonial. Uma tradição ainda bastante utilizada em nossos dias. Os santos representam uma intermediação entre Deus e os homens".

Portanto, os santos serão um apelo predominante entre estas mulheres da cura. O historiador Marc Bloch, ao escrever "Os reis taumaturgos”, esclarece um pouco sobre estas especialidades curativas dos santos:

A maioria dos santos verdadeiramente populares também possui seus talentos específicos: as pessoas dirigem-se a um deles rogando-lhe que cure os males dos olhos; a outro pedem que remedeie os males do ventre; e assim por diante. Mas, até onde se pode ver, essas especializações raramente estão lá desde o início; a maior prova está em que às vezes elas variam. Todo santo passa por médico junto ao povo; pouco a pouco, em virtude de associações de idéias freqüentemente obscuras, algumas vezes por um simples calembur, seus fiéis acostumam-se a atribuir-lhe o dom de mitigar, sobretudo esta ou aquela enfermidade; o tempo faz sua obra; ao fim de certo número de anos, a crença nesse poder bem determinado tornou-se no pobre mundo dos sofredores um verdadeiro artigo de fét.

Estas mulheres ainda manejam ramos verdes e são unânimes em afirmar que não cobram pelas suas rezas, mantendo o discurso de que a prática de reza é uma caridade. É comum ouvir destas mulheres que quem cura é só Deus, o poder da cura está com ele. Assim, como nos fala Dona Maria Lázaro:

SOUZA, Grayce Mayre Bonfim. Benzedura e Mentalidade: sobrevivência de uma prática historicamente acumulada. ANPUH - XXII Simpósio Nacional de História. João Pessoa, 2003, p. 4. Disponível em: < https://docplayer.com.br/9634518-Anpuh-xxii-simposio-nacional-de-historia-joao-pessoa-2003.html>. Acesso em: 20 jun. 2018.

6 RIBEIRO, Márcia Moisés. A ciência dos trópicos - A arte médica no Brasil do século XVIII Apud SOUZA, Grayce Mayre Bonfim. Benzedura e Mentalidade: sobrevivência de uma prática historicamente acumulada. João Pessoa, 2003, p. 4.

7 BLOCH, Marc. Os reis taumaturgos: o caráter sobrenatural do poder régio, França e Inglaterra. São Paulo: Companhia das Letras, 1993, p. 59. 
É porque se a gente reza em um bucado de gente e não tá com fé, às vezes não serve de nada, têm que ter a fé de Deus porque tá chamando Deus para a gente, para a pessoa, mais aí se num tiver um pingo de fé em nada, aí já era, daquela vez não serve não, pode vim outra vez. Num sei em quem eu rezei esta ultima vez e a pessoa disse que doeu tanto e eu disse, pois tenha fé em Deus que você vai ficar bom, eu nem pergunto isso as pessoas não, ela que mim diz. Eu não gosto não, porque eu não gosto mesmo, até que tem gente que diz que não sei de nada, aí eu digo ta é bom de mais (risos) só que eu sei mesmo ${ }^{8}$.

Não diferente para Dona Maria do Livramento, que vai dizer que: "Mas digo uma coisa, não é a gente que cura, mas sim Deus, porque tenho fé naquele pai, porque nós não faz, quem faz é Deus, porque se não tivermos fé aquela reza não está valendo nada9".

Fica, portanto, entendido que esta prática consiste na fé, ou seja, a cura se realiza no acreditar por parte de quem oferece a reza e de quem recebe, consistindo mais ainda na fé daquele que é bento.

Deste modo, com falas ricas em detalhes e singularidades, as benzedeiras deixam transparecer um tempo marcado pelas diversas experiências presenciadas e vividas por elas. Demonstrando ainda que a benzeção está muito além do ato da oração, dos símbolos e utensílios utilizados, está também nos seus olhares, rostos e semblantes. Não havendo uma receita pronta do processo de aprendizagem, do início, da transmissão do fazer de tal prática, tudo faz parte de um conjunto que se dá nos detalhes, nos silêncios, nas experiências em uma sabedoria inexplicável.

É uma prática que se constitui a partir de uma identidade coletiva, no entanto, cada benzedeira apresenta sua forma particular de realizar seus rituais, e sua maneira singular de benzer. Assim que, na história das benzedeiras, o social e o individual se entrelaçam.

Já em relação ao lugar da realização do ritual, parte muito da particularidade de cada benzedeira, Dona Maria Lázaro nos diz:

Rezo mais na minha cozinha, mais num tem lugar certo para eu rezar não, rezo na sala, na cozinha... Sei que rezei em três de uma vez, rezei em todos três aí nessa calçada aí fora, só a fé de Deus mesmo, aí eu rezei em um povo que fazia era por nome em mim, porque não ficava bom, aí num fica bom mesmo não, nem o camarada tem fé, nem o camarada sabe a reza ${ }^{10}$. anos, aposentada, moradora da comunidade do Sítio Belém, no município de Alcântaras-CE, em 31 de agosto de 2018.

10 Maria Ferreira Lino (Maria Lázaro). Entrevista já citada. 
Algo bastante interessante e importante a se frisar é o zelo e o cuidado que estas mulheres mantêm sobre este ofício. Uma transmissão e um conhecimento que é dado num intervalo de tempo longo e demorado. Algumas delas se dedicaram anos, usando do tempo não somente para apreender as rezas, mas também para apreender as coisas da natureza, tomando conhecimento sobre o mundo natural e mantendo uma relação muito próxima com a natureza. Portanto, neste tópico pretendeu-se apresentar um panorama cultural e social desses sujeitos históricos, uma vez que ficou entendido que não nasceram benzedeiras, mas tornaram-se. E para finalizar, trago uma citação de Sergio Buarque de Holanda, que diz:

Para estudar o passado de um povo, de uma instituição, de uma classe, não basta aceitar ao pé da letra tudo quanto nos deixou a simples tradição escrita. É preciso fazer falar a multidão imensa dos figurantes mudos que enchem o panorama da história e são muitas vezes mais interessantes e mais importantes do que os outros, os que apenas escrevem a história ${ }^{11}$.

\section{Fontes Orais:}

204

Maria Ferreira Lino, 73 anos, aposentada, moradora do Sítio Belém, Entrevista realizada por Maria Deiziane Lino, em 07 de maio de 2017. Sítio Belém, Alcântaras-CE.

Raimunda Marciano da Costa, 51 anos, aposentada, moradora do Sítio Milagre, Entrevista realizada por Maria Deiziane Lino, em 07 de agosto de 2018. Sítio Milagre, Alcântaras-CE.

Maria do Livramento de Menezes, 71 anos, aposentada, moradora do Sítio Belém, Entrevista realizada por Maria Deiziane Lino, em 07 de maio de 2017. Sítio Belém, Alcântaras-CE. 


\section{7. "Eu entrei nessa brincadeira quando eu era um menino". Memórias sobre o reisado groairense}

\section{Raimundo Sousa Alves ${ }^{1}$}

Eu vou levar esse bode/porque é meu ideal E eu vou levar esse bode/pra mostrar pro pessoal Quem tem barba puxa a barba/vai pro chiqueiro, bode Quem não tem puxa o bigode/vai pro chiqueiro, bode.

Esse bode quando dança/ ele faz o vai e vem Eu vou matar esse bode/num dou um taco a ninguém Quem tem barba puxa a barba/vai pro chiqueiro, bode Quem não tem puxa o bigode/vai pro chiqueiro, bode.

Esse bode é danado/ele parece com o cão Vai-te embora bode velho/senão eu te /dou um safanão Quem tem barba puxa a barba/vai pro chiqueiro, bode Quem não tem puxa o bigode/vai pro chiqueiro, bode. (Toada do Bode, cantada por Seu Tarcísio).

\section{Introdução}

O presente trabalho apresenta o reisado de Groaíras como uma manifestação da cultura popular que tem sobrevivido ao tempo e à ação da sociedade moderna, através da oralidade, uma vez que não foi encontrado nenhum registro escrito oficial desta expressão cultural até o ano de 2018, apesar das diversas edições de reisado existentes na história do município. O propósito deste trabalho é tentar identificar, aproximadamente, desde quando surgiu o reisado no município, buscando uma reconstrução do trajeto histórico até os dias atuais e apontando suas dificuldades para manter-se enquanto cultura folclórica sobrevivente.

Para atingir tal objetivo, este artigo está dividido em duas partes. Na primeira parte, apresentamos o pensamento de alguns autores sobre bases conceituais de cultura popular e cultura folclórica, com o objetivo de situar o reisado como expressão do folclore, através de um processo de resistência e adaptação, ora mantendo suas tradições, ora se reinventando. Na segunda parte, apresentamos os resultados de entrevistas realizadas com membros brincantes do reisado de Groaíras/CE, no intuito de coletar informações que 
nos possibilitem identificar uma origem aproximada do reisado neste município. As primeiras entrevistas foram realizadas no dia $1^{\circ}$ de maio de 2018 , individualmente com o líder do grupo, e no dia 4 de maio de 2018, com outros três componentes. Para efeito de complementação ou esclarecimentos, realizamos mais entrevistas com os mesmos membros nos dias 17 e 19 de setembro de 2018. Todas as entrevistas foram gravadas com a autorização dos participantes.

\section{Cultura popular e reisado: contextualização}

Ao longo da história da humanidade nos deparamos com uma diversidade de entendimentos ao tratarmos de cultura, uma vez que esta perde ou ganha elementos conceituais importantes, na medida em que se adequa ao tempo e ao espaço que a abriga, chegando, em muitos casos, a ser fonte de conflitos. Dos que a viam como herança genética aos que a defendem como um resultado do meio; dos que a relacionam ao conhecimento formal aos que a relacionam às expressões artísticas; dos que a usam para referir-se às festas e cerimônias tradicionais aos que a percebem como crenças, lendas e costumes; percebe-se que "cultura é definida como tudo aquilo que o homem cria, aprende, constrói e compreende, a partir de tudo que aprendeu por meio das experiências, vivências e estudos ao longo da vida"².

Dentro da cultura em geral, o conceito de cultura popular, segundo Mira (2016), tem sido objeto de disputas, tanto no campo teórico quanto no campo da produção. A autora aponta para uma construção teórica dos próprios agentes envolvidos com as práticas referendadas sob esta temática. Citando Burke (1989), Mira nos remete à ideia de cultura popular como uma volta à natureza, sinônimos de simplicidade e autenticidade, em contraponto com as elites das cortes. A ideia de cultura popular, assim, compreendia "os contos e cantos dos camponeses, suas danças e outras formas de expressão capazes de representar a pureza e a essência da nação"3.

A partir do século XVI, essa cultura festiva do mundo tradicional dos camponeses, entretanto, passou a ser fortemente reprimida por alguns setores da sociedade, como a religião. As missas cômicas e as paródias de textos canônicos levaram a Igreja Católica a considerar tal cultura como herética.

\footnotetext{
SOUSA, Maria de Lourdes Macena de. Sendo como se fosse. As danças dramáticas na ação docente do ator-professor. Escola de Belas Artes da Universidade Federal de Minas Gerais. Tese de Doutorado. 2014. Disponível em: file:///C:/Users/CRAS\%20SEDE\%2001/Downloads/sendo_como_se_fosse_tese_lourdes_macena.pdf, p. 46.

3 MIRA, Maria Celeste. Entre a beleza do Morto e Cultura Viva: a(s) cultura(s) popular(es) na virada do milênio e seus mediadores simbólicos. Caderno CRH v.29, nº 78. Salvador, set-dez, 2016. Disponível em: http://www.scielo.br/scielo.php?script=sci_arttext\&pid=S010349792016000300427\&lng=pt\&nr$\mathrm{m}=$ iso, p. 430 .
} 
Após a Reforma Protestante, a prática desta cultura passa a ser condenada por "motivo de ócio, desperdício e licenciosidade" ${ }^{\text {, }}$, provocando o afastamento das elites em razão da sua "vulgaridade e mau gosto" ${ }^{\text {. }} \mathrm{Na}$ segunda metade do século XX, ocorre uma espécie de retomada da cultura popular, agora sob forte viés antropológico, despida de conservadorismo típico dos séculos anteriores.

A cultura popular engloba o folclore, caracterizado pelo saber informal, aprendido e apreendido pelas vivências, pela oralidade, constituído pelo espontâneo e pela "inventiva humana peculiar e informal"'. Uma das expressões da cultura folclórica são as danças dramáticas, termo cunhado por Mário de Andrade, "para designar eventos espetaculares com características especificas, que utilizam dança, música, representação, ritos, crenças e brincadeiras de caráter ancestral" onde:

[...] encontra-se uma diversidade de personagens cômicos e livres em texto oral específico, sendo que a atuação de cada um depende de sua capacidade de inventiva própria, da forma como consegue improvisar a partir da realidade de cada momento vivido e, principalmente, a presença de um mundo fantástico diferenciado onde homens, bichos e outros seres caminham numa mesma ordem, numa única lógica, podendo cantar, dançar, falar e ter vida própria definida a partir de seu papel $^{8}$.

Carvalho recorre a Florestan Fernandes para apresentar a cultura popular enquanto uma dicotomia entre tradição/modernidade, cujas temporalidades contraditórias (elite/classe popular) resultam da institucionalização da sociedade capitalista, que atribuía às classes populares a conservação social e às elites as inovações 9 .

Como dança dramática, o reisado apresenta a característica da crença, da devoção e do rito. Brantes nos aponta o espetáculo como sendo:

[...] uma forma de devoção associada ao episódio bíblico da visita dos três Reis Magos ao Menino Jesus (Tinhorão, 2000).

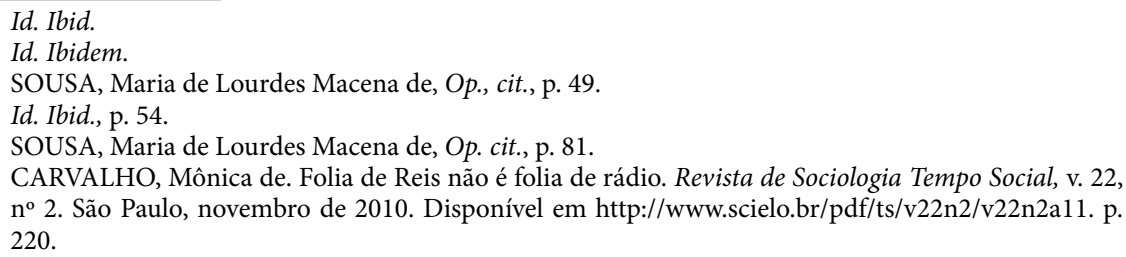


Entre os dias 25 de dezembro e 6 de janeiro, os reiseiros peregrinam pelas comunidades rurais vizinhas entrando de casa em casa. O ritual da visita é baseado numa relação de troca material e espiritual entre os devotos, o dono-da-casa e o Santo Reis. Os devotos abençoam a casa com cantos sagrados e recebem dinheiro dos donos-das-casas para a realização da festa em homenagem ao Santo, que acontece no final do período de peregrinação ${ }^{10}$.

Em consonância com Brantes, Farias complementa que o reisado "foi introduzido no Brasil pelos portugueses no século XIX" 11 , enfatizando que "no interior é uma dança do nascimento de Jesus Cristo e homenagem aos Reis Magos Gaspar, Melchior e Baltazar, que levaram ouro, incenso e mirra, representando as três dimensões de Cristo: realeza, divindade e humanidade"12.

Brantes assinala que o reisado foi objeto de estudos no campo do folclore até a década de 1960, passando nas décadas de 1970 e 1980 a ser objeto estudado na seara do catolicismo popular, analisados por cientistas sociais, com foco nas relações de trocas sociais no meio rural. Pesquisadora com experiência teatral e "reiseira", Brantes nos apresenta o Reisado do Mulungu no município de Boninal, situado na Chapada Diamantina, na Bahia, como processo de "sacralização" dos lares que recebem a visita dos devotos.

Como um dos primeiros registros sobre o reisado no Ceará, Nunes nos aponta uma "Festa de Reis do Congo", no século XVIII, narrada por Dom José Tupinambá da Frota em seu livro "Histórias de Sobral", de 1974. Segundo a autora,

\begin{abstract}
A festa era celebrada no dia 27 de dezembro pela Irmandade Nossa Senhora do Rosário dos Pretos, recebendo a denominação de Reisado. Esta se tratava da coroação de um rei Cariongo e de uma Rainha, em cortejo festivo, apresentação de "cantigas" e entremezes onde aparecia inclusive a negra Catirina, personagem que aparece na maioria dos reisados atuais ${ }^{13}$.
\end{abstract}

10 BRANTES, Eloísa. A espetacularidade da performance do ritual no reisado do Mulungu (Chapada Diamantina - Bahia). Revista Religião e Sociedade, v. 27, $\mathrm{n}^{\circ}$ 1. Rio de Janeiro, 2007. Disponível em: http://www.scielo.br/pdf/rs/v27n1/a02v27n1.pdf., p. 25.

11 FARIAS, Maria Jozeneura Florencio. O Reisado como tradição de um povo. Meruóca-CE. (2005 a 2011). In: SILVA JÚNIOR, Agenor Soares e; SANTOS, Carlos Augusto Pereira dos. Histórias do Ceará. Experiências de pesquisas dos alunos e professores do PARFORUVA. Sobral-CE. 2009-2011, Fortaleza: Expressão Gráfica, 2013, p. 94

12 Idem.

13 NUNES, Cícera. Os reisados em Juazeiro do Norte-CE e os conteúdos da história e cultura africana e afrodescendente: uma proposta para a implementação da Lei no 10.639/03. Programa de Pós-Graduação em Educação Brasileira da Universidade Federal do Ceará - UFC. Dissertação de Mestrado. Fortaleza/CE, 2007. Disponível em: http://www.repositorio.ufc.br/bitstream/riufc/2982/1/2007_dis_ CNunes.pdf, p. 104. 
Farias ressalta a importância de manter a tradição no reisado da Meruoca-CE, um dos mais tradicionais da zona norte do estado. A autora nos apresenta o reisado local como "uma festa colonial de resistência à dominação a partir dos antepassados"14, mas enfatiza as alterações sofridas pelo folguedo nas diversas regiões onde era praticado, "adquirindo ares de renovação por meio da festa"15.

$\mathrm{Na}$ cultura popular, a tradição convive diretamente com a renovação, já que a memória é o terreno próprio de sua existência e se reatualiza a partir da própria dinâmica da sociedade. Nas palavras de Sousa:

Tradição é o ontem no hoje, no aqui e agora, naturalmente. É o que se faz cotidianamente, independentemente dos modismos e das novidades. Ela é parte integrante também do que se chama de atual, pois é feita na contemporaneidade, com uma diferença: tem mais tempo de vida e existência e, portanto, mais referência no grupo social, fortalecendo os aspectos identitários do próprio grupo ${ }^{16}$.

A respeito da relação dicotômica tradição/modernidade, presente no reisado, Sousa analisa o Reisado da Comunidade Cipó de Baixo, no município de Pedro II, no Piauí, buscando os processos de permanência e resistência presentes na brincadeira nos tempos atuais, considerando os movimentos constantes do tempo e da vida social que promovem os processos de continuidade e rupturas.

O autor apresenta as novas tecnologias, saberes múltiplos, demandas políticas, comportamentos plurais, economia, direitos humanos, entre outros, como fatores que "têm levado a humanidade a uma continuada e acelerada transformação"17. Em se tratando do reisado, Sousa nos mostra algumas mudanças já perceptíveis na tradição, tais como: ampliação do calendário da festa, que antes era de 25 de dezembro a 6 de janeiro; articulações com escolas e agentes públicos como possíveis parcerias, apresentações em outras datas do ano; e palestras como novos recursos utilizados na tentativa de preservação da tradição.

Mas o reisado é, também, preservação e fortalecimento de padrões tradicionais de sociabilidade, principalmente nas comunidades rurais. As apresentações possuem um poder que Baumann chama de "poder aglutinador

\footnotetext{
FARIAS, Maria Jozeneura Florencio, Op. cit., p. 94.

Idem.

SOUSA, Maria de Lourdes Macena de, Op. cit., p. 64.

SOUSA, Luciano de Melo. Brincadeira do reisado na modernidade: identidade cultural que navega entre resistência e transformação. Revista História e Cultura, v.2, n 2. Franca, São Paulo, 2013. Disponível em: file://C:/Users/edvan/AppData/Local/Packages/Microsoft.MicrosoftEdge_8wekyb3d8bbwe/ TempState/Downloads/879-3865-1-PB.pdf, p. 215.
} 
Nossa Gente,

Nossa História

o Ceará Republicano

das vizinhanças"18, a partir do movimento que Brantes chama de "relações entre os devotos/Santo/dono-da-casa"19, onde a dimensão do levar a festa se sobrepõe à dimensão do ir à festa.

E, mesmo em tempos de fragmentação, individualismo, competitividade e crise das tradições, o reisado mantém acesa a chama da cultura folclórica, talvez porque a história dos brincantes e amantes do reisado e, muitas vezes, da própria comunidade, se confunda com a história das práticas culturais. Nas palavras de Sousa, "brincantes e amantes do reisado renovam certas crenças, laços sociais, costumes e valores, ano após ano"20 em um processo de reconhecimento e pertença social.

\section{$\mathrm{O}$ reisado de Groaíras-CE}

Groaíras é um município de pequeno porte I, segundo classificação estabelecida pelo Instituto de Pesquisa e Estratégia Econômica do Ceará - IPECE, baseada no contingente populacional. Com 61 anos de emancipação política, Groaíras fica situado na zona noroeste do Estado do Ceará e conta com pouco mais de 10 mil habitantes, dos quais mais de 3 mil residem na zona rural, segundo o Censo de 2010. Sua extensão territorial é de aproximadamente $157 \mathrm{~km}^{2}$ e sua divisão administrativa conta com um distrito (Itamaracá). Entre suas expressões culturais, destacam-se festejos religiosos da Padroeira Nossa Senhora do Rosário, o Carnaval e o Reisado.

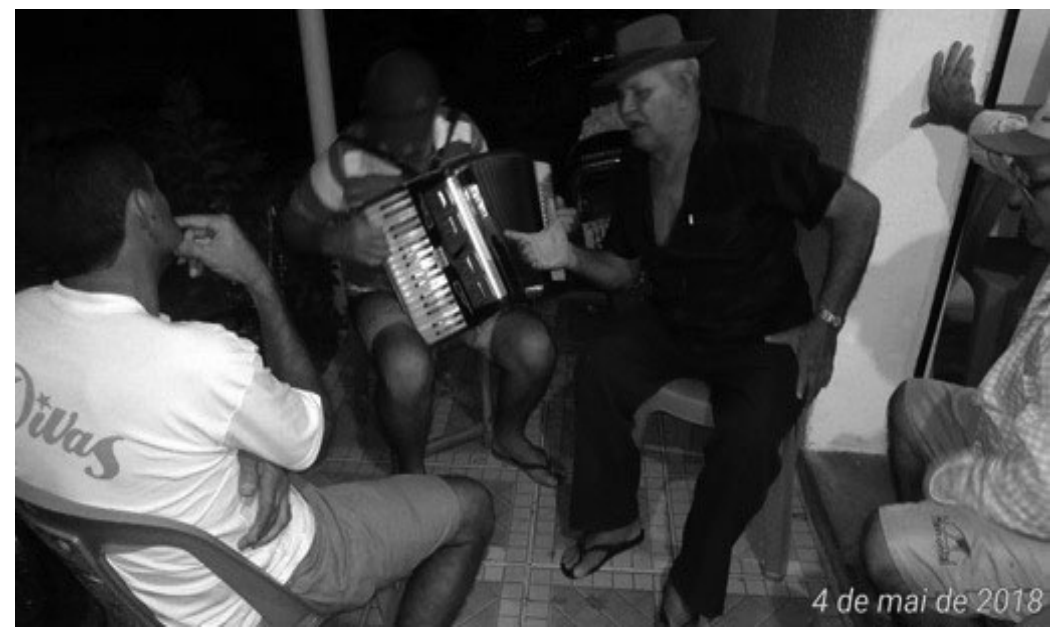

Figura 1. Ensaio do Grupo de Reisado Groairense. Em sentido horário: Eliézio, Otalicio, Tarcísio e Sansão. Registro fotográfico feito pelo autor em 04 maio 2018. Groaíras-CE.

\footnotetext{
8 BAUMANN, 2005, Apud SOUSA, Luciano de Melo, Op. cit., p. 218

9 BRANTES, Eloísa, Op. cit., p. 26.

20 SOUSA, Luciano de Melo, Op. cit., p. 218.
} 
O reisado no município é, atualmente, representado por apenas um grupo, o Reisado da Cultura Groairense, formado em 2017, tendo como Mestre o Sr. Antônio Elias Melo ${ }^{21}$, conhecido por todos como Sansão, e como componentes principais os Srs. Tarcísio Francisco Oliveira ${ }^{22}$, conhecido como Tarcísio Brasiliano; Otalício Loiola $\mathrm{Melo}^{23}$, conhecido por Otacílio; e Francisco Eliézio ${ }^{24}$. Existem também outros brincantes, como os "meninos gêmeos", mas estes iniciaram suas atividades neste grupo há pouco tempo, não tendo outros registros de reisados e, por isso, não foram entrevistados por ocasião deste trabalho.

Os primeiros grupos dançantes do reisado no município de Groaíras, segundo a narrativa de Seu Sansão, eram originários de duas localidades: Boa Vista e Floresta ${ }^{25}$. Segundo Seu Sansão, "se batia, Boa Vista com a Floresta, eles era tudo duma idade" ${ }^{26}$. Nenhum dos dois grupos existe mais, deixando uma lacuna imensa para a cultura popular do município. A retomada da tradição do reisado pelo grupo liderado por Seu Sansão é de extrema importância, por manter viva a cultura popular. Por entender que a tradição do reisado é importante para todo o município, o grupo escolheu o nome Reisado da Cultura Groairense a fim de incluir todo cidadão do município que deseje participar.

De acordo com a narrativa dos membros do Reisado da Cultura Groairense, não há como precisar a data de origem do reisado em Groaíras, pois todos são unânimes em dizer que desde sua infância já viam suas famílias envolvidas com o folguedo e acreditam que a tradição vem de tempos mais antigos. Mas os brincantes também apresentam contradições em suas informações. Tarcísio aponta para o Reisado dos Silivanas como sendo o mais antigo da sede, perdendo apenas para o Reisado do Capim. Já Mestre Sansão relata que

Aqui em Groaíras mermo num tinha, é no sertão. Tinha Boa Vista, que era os nossos. Tinha aqui na Floresta, que era do Pe-

${ }_{21}$ O Sr. Antonio Elias Melo, conhecido por todos como Seu "Sansão", é agricultor aposentado, nasceu em 05/08/1945, na localidade de Fechado, interior do município de Groaíras. Começou como brincante de reisados aos 12 anos de idade, já desempenhando o personagem do Boi, ou "boieiro". Interrompeu a participação com a maioridade e a mudança para o Rio de Janeiro, e a retomou em 2016, quando reuniu alguns amigos e criou seu próprio grupo de reisado.

22 Tarcísio Francisco Oliveira, 82 anos, agricultor aposentado, nasceu em 13/01/1936 na Boa Esperança dos Melos, localidade mais distante da sede. Seu Tarcísio desempenha o papel de Magarefe, tendo começado com aproximadamente 30 anos, mas enfatiza que brinca em todos os papeis.

23 Otalício Loiola Melo, 66 anos, agricultor aposentado.

24 Francisco Eliézio Araújo Alves, agricultor de subsistência, nasceu em 11/09/1966, na localidade de Capim. Iniciou suas atividades no reisado desde os 19 anos de idade, incentivado pelo pai, a quem considera "um grande homem da cultura". Desempenha o personagem de Mateus. Ficou afastado do reisado por muitos anos, retomando as atividades em 2016.

25 Localidades rurais que ficam distantes da sede em aproximadamente $5 \mathrm{~km}$ a $8 \mathrm{~km}$.

26 Antônio Elias Melo (Mestre Sansão). Agricultor. Entrevista realizada pelo autor em $1^{\circ}$ de maio de 2018. Groaíras-CE. 
dro Paiva né, os Paiva. Tinha os Silivanas, né, os Silivanas... Os Paiva era junto com os Biana, também era um reisado bom ${ }^{27}$.

Seu Sansão nos informa que participa de reisados desde seus 12 anos, quando "eu brincava de bate-boi, eu tinha um irmão que era mais velho e brincava de careta também" ${ }^{28}$. Seu Sansão relembra as dificuldades da época, quando "a gente carregava o boi na cabeça, distância de três léguas ${ }^{29}$, um levava um pedaço (tempo), outro levava outro... não tinha carro na época... quando não era na cabeça, era na garupa da bicicleta" ${ }^{30}$. De maneira saudosa, o brincante relembra um grande grupo de amigos que brincavam reisado junto com ele. Seu Tarcísio arremata:

O boi era assim: nós tinha um rapaz que brincava nas figuras e ele levava o boi na garupa de uma bicicleta.... Amarrava com a liga, inda botava mais aquela burrinha dentro, e o bode... aí quando dava o vento, rapaz, faltava derrubar o cara com o boi $(\text { risos })^{31}$.

Tarcísio Francisco Oliveira, conhecido como Tarcísio Brasiliano, é o membro mais velho do grupo e seus 82 anos revelam que o reisado tem raízes mais antigas ainda. Seu Tarcísio relata que desde menino acompanhava o reisado e que já existia por estas terras a tradição do folguedo. "Quando eu entrei no reisado das crianças aí eles descobriram que eu era, parece que eu já era acostumado a brincar, eu fazia tudo né, todas entradas... aí eu fui ser magarefe" 32 .

\footnotetext{
Idem.

Idem

29 Idem. Légua: medida de distância antiga, usada ainda na atualidade, que equivale a pouco mais de $4 \mathrm{~km}$ cada.

30 Antônio Elias Melo (Mestre Sansão). Entrevista já citada.

31 Tarcísio Francisco Oliveira, 82 anos, agricultor. Entrevista realizada pelo autor em 4 de maio de 2018. Groaíras-CE.

32 Idem. Magarefe é o personagem do Reisado responsável pela morte do boi.
} 

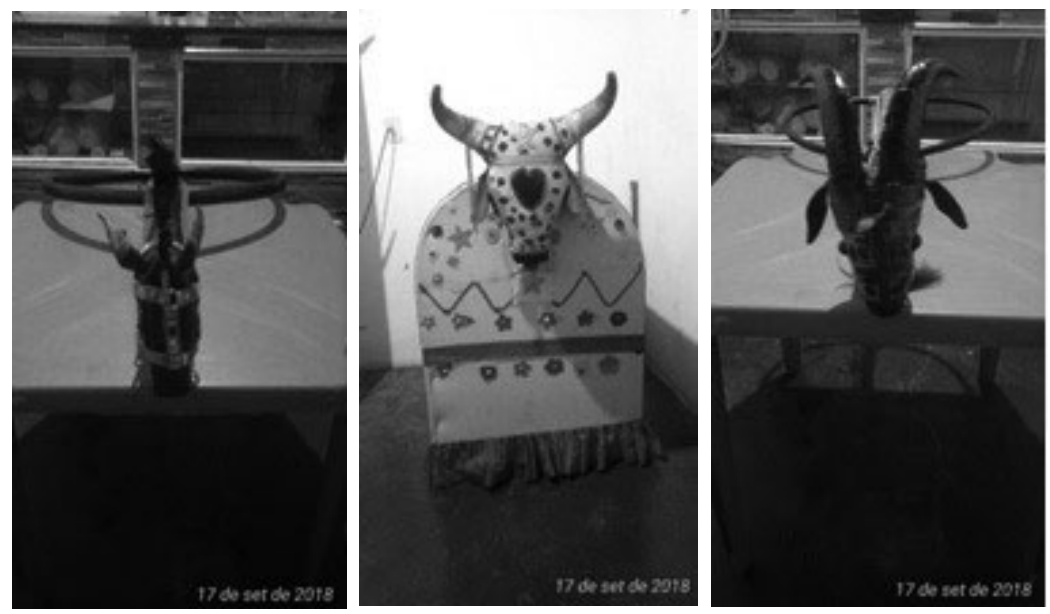

Figura 2. Estruturas utilizadas pelos brincantes do Reisado. A Burrinha; o Boi; e o Bode. Registros feitos pelo autor em 17 set. 2018. Groaíras-CE.

Os outros dois membros entrevistados, Otacílio Loiola Melo, conhecido por Otalício, e Francisco Eliézio, são os mais jovens do grupo, tendo respectivamente, 66 e 52 anos de idade, e relatam que iniciaram suas participações no reisado ainda crianças, a partir da vivência de seus pais na tradição. Seu Otalicio conta que:

Eu entrei nessa brincadeira quando eu era um menino, eu nasci e me criei no Flamengo... e outro, que meu pai foi quem tocou muitos anos em reisado, Afonso Melo, ele era um grande artista pra tocar reisado... eu menino ia acompanhando também, nés3.

Para Seu Eliézio, entrar no reisado tinha também uma conotação de homenagem ao pai, já falecido.

Quando meu pai brincava com o Tarcísio, Antero Biano, Eduardo, finado Pedro Paiva... sempre eu ia pros terreiros só escutar, admirar e decorando alguma coisinha sobre a cultura... brinquei pouco tempo com ele, foi o tempo que Deus levou ele, né, aí eu fiquei, então essa homenagem eu levo considerando meu pai, é o mesmo que ele tá vivo ${ }^{34}$.

O grupo relata que o município ficou um tempo sem reisado, apontando para um "sumiço" do folguedo. De acordo com informações aproximadas,

33 Otacílio Loiola Melo, 66 anos, agricultor. Entrevista realizada pelo autor em 4 de maio de 2018. Groaíras-CE.

34 Francisco Eliezio Araújo Alves, 52 anos, agricultor. Entrevista realizada pelo autor em 4 de maio de 2018. Groaíras-CE. 
não houve reisado na cidade por uns 15 anos, "depois da saída do Antônio Júlio", brincante tradicional, sem, no entanto conseguirem definir uma data para este evento. Os membros comentam um retorno do reisado em 2005, durante a gestão da prefeita Zoélia ${ }^{35}$, que no primeiro ano "botou oito reisado por conta dela, no ano que ela assumiu!"36, repetindo o feito em 2006.

Os brincantes relatam que houve edições do reisado em outras gestões, como, por exemplo, na gestão José Almir ${ }^{37}$ e na gestão Ueliton ${ }^{38}$, e que apenas na gestão Adail Melo ${ }^{39}$ não houve nenhuma edição do reisado em Groaíras. No início do ano de 2017, surgiu um reisado na localidade de Boa Vista e Mestre Sansão foi assistir. Entretanto, ficou decepcionado com o folguedo, o qual, a seu ver, trouxe muitas incoerências com a brincadeira tradicional, inclusive personagens que não existem. "Inventaram um 'lubisone' que era um menino dentro dum saco de plástico com um balde na cabeça, sem graça nenhuma ${ }^{40}$.

Sobre o diálogo entre a tradição e a renovação, Sousa enfatiza o mundo das relações sociais baseadas na proximidade como sendo o responsável pela organização do reisado, mas lembra que, assim como as relações sociais, o reisado também está exposto às diversas referências culturais do mundo globalizado, numa dinâmica de manutenção e permanência da tradição versus a desconstrução e recriação da cultura.

Na era moderna, vimos nascer um mundo globalizado e com relações já não tão calcadas na proximidade e no sentimento de pertença. Os avanços trazidos por este tempo histórico exaltam o individualismo em detrimento do comunitário e, com isso, valores tradicionais foram redimensionados. Segundo Sousa:

O discurso pós-moderno trouxe a ideia da aldeia global, onde os meios de comunicação de massa fizeram do mundo o lugar de um povo só, com padrões pré-estabelecidos para bens de consumo e formas de agir, reconfigurando padrões estéticos e comportamentais, possibilitando a cada um a ideia das múltiplas identidades ${ }^{4}$.

Mas, como já dito, a memória é o chão da cultura popular e da cultura folclórica. E mesmo dividindo espaço com o novo, com o revisitado, com o redimensionado, alguns parâmetros se fixam como pontos de subsistência

\footnotetext{
Maria Zoélia Loyola foi eleita prefeita do município de Groaíras para o mandato de 2005-2008.

6 Antônio Elias Melo. Entrevista já citada.

José Almir Matos Lopes foi eleito prefeito de Groaíras para o mandato 2009-2012.

38 Francisco Ueliton Vasconcelos é o atual prefeito de Groaíras, eleito para o mandato de 2017-2020.

39 Adail Melo foi eleito prefeito de Groaíras para o mandato de 2013-2016.

40 Antônio Elias Melo. Entrevista já citada.

41 SOUSA, Maria de Lourdes Macena de, Op. cit., p. 65.
} 
dos constructos tradicionais. Apesar do hiato de tempo entre o período em que brincava reisado e a apresentação atual, Seu Sansão não esqueceu os detalhes da brincadeira, e sentiu-se na obrigação de resgatá-la e trazê-la para as novas gerações.

Eu disse lá, disse: olha turma, eu vou fazer um boi de reisado, vou fazer uma burra, vou preparar um reisado, viu? Vou preparar. Quando, se a gente preparar, a gente bota em campo. Eles disse: ora mais, isso num vai pra frente não. Eu digo vai, vai, depende de você ter gosto pra fazer ${ }^{42}$.

A “obrigação" citada por Seu Sansão talvez advenha da sua posição no reisado: mestre. O Anuário do Ceará 2018-2019, em sua seção "Mestres da Cultura do Ceará", refere-se aos mestres como tendo papel principal na produção, conservação e transmissão da cultura popular, preservando a memória cultural do reisado e garantindo a perpetuação dos saberes e fazeres desta tradição (CEARÁ, 2018). Segundo Sousa:

Mestre - é aquele que detém o saber popular ancestral mantido na memória, e o vai repassando pela convivência, no cotidiano, na vida que leva para sua comunidade ou seu grupo. É conhecido também como "tesouro vivo" do lugar e se relaciona com os bens Imateriais, nos estudos do patrimônio. Hoje, existem várias recomendações, inclusive da UNESCO, para a atuação e relações de experiências com estes nas escolas para valorização e reconhecimento desses saberes ancestrais, principalmente no lugar onde elas existem ${ }^{43}$.

No intuito de contribuir com "o reconhecimento, a proteção e a valorização da diversidade de conhecimentos, fazeres e expressões das culturas populares e tradicionais no Ceará" ${ }^{44}$, a Secretaria Estadual de Cultura do Ceará - SECULT realiza desde 2004 o Edital "Tesouros Vivos da Cultura”. O objeto do Edital é a seleção e nomeação de pessoas, grupos e coletividade "dotados de conhecimentos e técnicas de atividades culturais, cuja produção, preservação e transmissão [...] sejam representativas de elevado grau de maestria $[\ldots]^{\prime \prime 4}$. A escolha é feita por comissão específica, baseada em critérios como relevância da vida e obra para a cultura; experiência e vivência dos costumes

42 Antônio Elias Melo (Mestre Sansão). Entrevista realizada em $1^{\circ}$ de maio de 2018.

43 SOUZA, Maria de Lourdes Macena de, Op. cit., p. 32.

44 CEARÁ, Governo do Estado. Anuário do Ceará 2018-2019. Mestres da Cultura do Ceará. Disponível em http://www.anuariodoceara.com.br/mestres-da-cultura-do-ceara/. Último acesso em: 11 set. 2018, p. 1.

45 Idem. 
e tradições culturais; capacidade de transmissão e partilha do saber cultural; entre outros.

Apesar da existência de mecanismos legais de incentivo à cultura, ainda persistem dificuldades em se manter a tradição cultural do reisado. No caso de Groaíras, Seu Sansão aponta a falta de incentivos do poder público como um dos fatores determinantes. "O pessoal não tiveram mais gosto né? Os próprios políticos num teve mais incentivação do reisado" ${ }^{46}$, afirma Seu Sansão, rememorando os tempos em que os políticos eram os primeiros a solicitar a apresentação do reisado em suas propriedades. Além disso, os custos financeiros de se fazer um reisado são consideráveis. Seu Eliézio nos lembra dos gastos referentes ao folguedo:

[...] é porque saí altíssimo viu, você organizar. Só ele aí (Sansão) quem sabe o preço altíssimo. Porque juntar o grupo é uma coisa e fazer as figura é outra. Porque vem as figuras, vem o nosso traje, vem o sapato, isso tudo é caríssimo ${ }^{47}$.

Para uma apresentação bem-feita, são necessários diversos materiais, além do trabalho de alguns profissionais, inclusive o pagamento dos brincantes, que hoje não se apresentam mais de forma gratuita, apenas pela brincadeira. Além disso, é necessária também toda uma estrutura, como transporte, divulgação, som, que necessita de incentivos tanto do poder público quanto da população, contratando o grupo de reisado para apresentações particulares. Todo este aparato revela em si um processo de ruptura com a brincadeira tradicional, realizada de maneira mais artesanal, em geral em torno de uma comunidade pequena ou familiar.

A respeito do retraimento das políticas públicas de incentivo à cultura popular e à cultura folclórica em especial, Sousa nos apresenta o pensamento de Mário de Andrade no livro Danças Dramáticas do Brasil, no qual o autor enfatiza uma possível morte das danças estudadas por ele e sua equipe no século XX. Sousa, no entanto, discorda desta perspectiva, afirmando que, mesmo diante do retraimento ou da ineficiência das políticas públicas voltadas à cultura, "temos hoje danças dramáticas espalhadas em grande parte do território brasileiro, resistindo e se reinventando diante do contexto sociocultural em que vivem e/ou que lhes é imposto" ${ }^{48}$.

Segundo Sousa, as festas familiares e comunitárias que não contavam com a mediação monetária, as composições sem direitos autorais, os encontros para contar os "causos", as falas libertas de regramentos e cheias de

46 Antônio Elias Melo. Entrevista já citada.

47 Francisco Eliezio Araújo Alves. Entrevista já citada.

48 SOUSA, Maria de Lourdes Macena de, Op. cit., p. 49. 
irreverência, são características de relações construídas em ambientes mais tradicionais ${ }^{49}$. Em contraponto, o autor nos apresenta fatores como a indústria cultural, a competição, a qualificação e o status econômico como características de relações modernas, conflitantes com o mundo da "solidariedade comunitária" ${ }^{50}$.

Além do incentivo do poder público, o líder do reisado de Groaíras aponta também a falta de interesse da população em receber o reisado. Segundo os brincantes, muitas localidades no interior de Groaíras têm algum estabelecimento comercial do tipo bar, considerado normalmente como o único ponto de "diversão" da localidade. Os proprietários também podem patrocinar a tradição, recebendo em troca ganhos com a venda de produtos. Um dos entrevistados narra uma destas experiências.

Lá no Diolindo, lá no Barro Duro, nós fomo brincar lá... lá é por conta deles mesmos, num teve prefeitura, ele mesmo patrocinou, pagou né, disse que gostou... Deu pra se sair bem né, que vendeu muita cerveja, tinha muita gente... que aí o pessoal não vê isso, né? ${ }^{51}$

Os brincantes recordam dos tempos áureos do reisado em Groaíras, na década de 1960 a 1970. Seu Eliezio recorda que "era tanta tradição que eu alcancei, criança, meu pai levando um banco pros filhos e a esposa dele se sentar porque era um mundo de gente tão grande, rapaz" ${ }^{2}$. O grupo recorda que eram tempos em que não se tinha as facilidades e tecnologias que se tem nos dias de hoje, conotando a estes uma maior valorização e preservação das práticas culturais, além de serem mais propensos ao encontro, às reuniões familiares e comunitárias.

Naquele tempo fazia tudo no escuro, num tinha luz, num tinha televisão, todo evento, até uma cantoria que tinha, era assim, lotado... hoje o pessoal, esse negócio de televisão é não sei o quê, internet é não sei o quê, é pouca gente que dá valor essas coisa $^{53}$.

Recordar é algo que os membros entrevistados fazem muito bem. Apesar de não haver registros escritos oficiais sobre o reisado, os membros lembram de cor todos os versos, ou toadas, como eles designam. Toda a tradição foi passada através da oralidade. Seu Tarcísio relata que "tô com 82 anos, acredi-

\footnotetext{
SOUSA, Luciano de Melo, Op. cit., p. 216.

Idem.

Antônio Elias Melo (Mestre Sansão). Entrevista já citada.

Francisco Eliezio Araújo Alves. Entrevista já citada.

Otacílio Loiola Melo. Entrevista já citada.
} 
ta nisso? E faço esse trabalho, e até hoje não esqueci de nada" ${ }^{54}$. Seu Otalício relembra que "eu tenho o reisado todim gravado na minha memória" ${ }^{55}$, cultura aprendida com a observação do pai brincando o folguedo. Seu Tarcísio complementa que "ele aí (Otalício) acompanhava, ele conhecia o meu ritmo todo... ele tinha tudo decorado" ${ }^{56}$. As falas mostram a importância que teve a memória e a oralidade para a manutenção da tradição do reisado de Groaíras.

Um fator complicador para a continuidade da tradição é a participação dos brincantes, que hoje só brincam por algum valor em dinheiro. Seu Sansão explica que o ideal seria que a brincadeira pudesse ser gratuita, assim todas as pessoas poderiam ter acesso, tanto como brincantes quanto como população. Entretanto, isso não é possível.

Os caretas não pode se 'deslocalizar' da sua casa até dez da noite, meia noite, todo dia, pra ir brincar a troco de quê... Suar, se cansar né? Tem que ganhar ao menos o do café no outro dia né? Que aí tocava o quê... tocava uma michariazinha pra cada um de 40 reais, $30 \ldots{ }^{57}$.

Sobre a importância da retomada do reisado, os membros são uníssonos: Seu Sansão merece todo o mérito. "Ele (Sansão) que incentivou, mandou fazer as figuras, comprou sanfona, os calçados, chapéu de couro, tudo, tudo"58, afirma Seu Tarcísio. "O reisado era pra não existir mais. Se ele aí (Sansão) não faz, pronto, tinha se acabado" 59 , confirma Seu Otacílio. Seu Eliezio complementa, mostrando sua admiração pela forma com que o líder conduz o grupo, afirmado que "de chefe, eu já acompanhei reisado com muito chefe. Brinquei com chefe Antônio Júlio novo, chefe Domingos Crispim, mas chefe pra mim de alto nível se chama Seu Sansão"60.

O reisado também tem sua dimensão social. Novos integrantes, adolescentes e jovens, estão chegando e desempenhando papeis importantes, como o Magarefe. Seu Sansão relata a fala de dois irmãos, adolescentes de 13 anos que residem na Floresta, que foram à sua casa se disponibilizar para brincar o reisado. Impressionado com a atitude dos adolescentes, o líder perguntou se eles realmente teriam o compromisso necessário para a empreitada: "Mas vocês garante mermo vir brincar o reisado e num faltar? ${ }^{21 "}$ Ao que eles responderam: "Ora, 'mairrapaz', se é de nós tá em casa e usar maconha, droga, nós vem é brincar reisado, que droga num ficou pra gente" 62 .

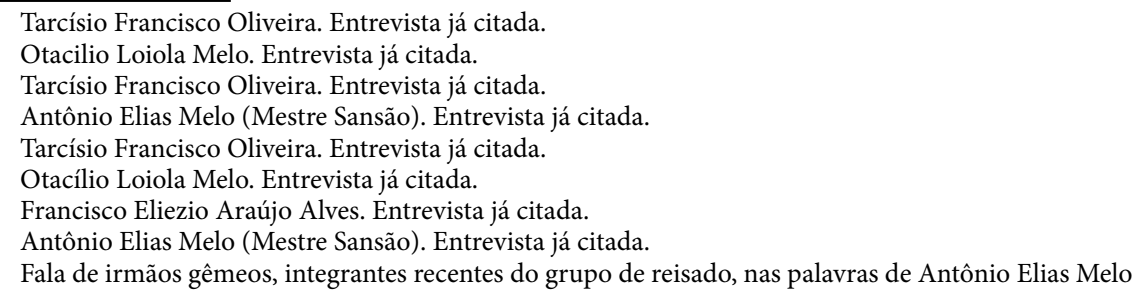


O grupo, entretanto, diverge em relação ao interesse dos mais jovens. "O público jovem não tem perigo dele vim pra cá”"63, lamenta Seu Otacílio. Já Seu Eliézio recorda que "sempre eu acompanhava essa brincadeira, essa cultura maravilhosa, sempre eu tinha um incentivo..." ${ }^{4}$, fazendo alusão à figura de seu pai, grande incentivador da brincadeira do reisado. Seu Tarcísio pontua apenas que aos mais jovens faltam trejeitos necessários para a brincadeira. "Pela idade né? Porque os novatos não pega" ${ }^{3}$, nos diz o idoso, apontando isso como uma das dificuldades em manter a tradição.

Esse movimento de resistência, tanto dos brincantes antigos em aceitar os novos, quanto dos novos em participar do reisado, talvez encontre explicação na própria essência do folguedo. O reisado é uma festa coletiva que exige criatividade e inventiva da parte dos brincantes, já que "mesmo algumas delas tendo textos orais fixos, seus brincantes vão atualizando-os, alterando pequenas partes para tornar sua brincadeira sempre nova diante do grupo" 66 .

Sobre a dificuldade de ser líder de um grupo de reisado, Seu Sansão revela o segredo: "tem que ter muita paciência, porque aí são dez opinião" ${ }^{67}$. O líder relata que cada brincante tem personalidade própria e lidar com todas elas juntas é o grande desafio: "As veiz eu ficava em pé ali sem saber o quê que eu ia fazer... chegava lá, que ia brincar, aquele negócio, vestir aqueles traje e tudo, uns queria vestir de um jeito, outros queria vestir de outro... você vê a ideia do povo" 68 .

Questionados sobre o que lhes motiva para dar continuidade à tradição do reisado, os membros do grupo relatam o prazer que têm em brincar e a dimensão de homenagem de cada um aos seus familiares. Seu Eliézio recorda o quanto o pai lhe ensinou: "Vez em quando papai tocava essas toadas de reisado, e eu só ouvindo... hoje eu sei delas tudin, eu sei o reisado todo completo" $^{69}$. Nas palavras de Seu Sansão,

O que me motiva? Rapaz é só o prazer que eu tenho né? Aquele prazer daquela brincadeira porque eu gosto né? Desde de eu pequeno né, de minino, que eu assistia a gente brincar em reisado... Muito bom, muito beleza... e num tem outra, num tem outra, outra diversão, outra coisa aqui na Groaíras, num tem, você pode procurar que num tem. A num ser um forró dum bate chinelo ali, tal e tal, outra coisa num tem ${ }^{70}$.

(Mestre Sansão). Entrevista já citada.

3 Otacilio Loiola Melo. Entrevista já citada.

64 Francisco Eliezio Araújo Alves. Entrevista já citada.

65 Tarcisio Francisco Oliveira. Entrevista já citada.

66 SOUSA, Maria de Lourdes Macena de, Op. cit., p. 83.

67 Antônio Elias Melo (Mestre Sansão). Entrevista já citada.

68 Idem.

69 Francisco Eliezio Araújo Alves. Entrevista já citada.

70 Antônio Elias Melo (Mestre Sansão). Entrevista já citada. 


\section{Considerações finais}

Pelo relato dos entrevistados, concluímos que o reisado tem raízes no município de Groaíras que remontam a períodos anteriores à década de 1936, data de nascimento do membro mais velho, Seu Tarcísio, indicando que o folguedo já era brincado antes mesmo da emancipação política do município, que data do ano de 1957. Os mesmos relatos dão indicativos de que a tradição data de tempos mais antigos, não sendo possível, entretanto, especificar uma data exata.

Como fatores que dificultam a continuidade da tradição do reisado em Groaíras, os brincantes apontaram para a falta de interesse do poder público e dos proprietários privados; o alto custo para se promover cada edição do reisado; a idade dos membros atuais, que dificultam a apresentação de uma performance condizente com o folguedo; e a pouca adesão de novos membros, para ventilar a tradição e garantir sua continuidade.

Além de todos estes fatores, entendemos também que a falta de registros escritos oficiais sobre o reisado de Groaíras é mais um fator que dificulta a continuidade desta tradição, que tem sobrevivido de maneira exclusivamente oral, passada de geração em geração, o que pode ser considerado um risco para o folguedo, já que pelos relatos dos membros, o interesse da população tem diminuído ao longo dos anos.

Assim sendo, entendemos que este trabalho, para longe de trazer soluções para o problema da continuidade do reisado de Groaíras, na verdade expressa ainda mais problemas que necessitam do olhar público e comunitário, com o intuito de não deixar morrer a tradição da brincadeira de reisado no nosso município.

Sugerimos, além de medidas públicas de valorização e disseminação do reisado, outros trabalhos que possam contribuir para o registro escrito oficial sobre o folguedo, garantindo assim sua perpetuação enquanto cultura e expressão histórica de um povo. 


\title{
18. Corpo em movimento, Street Dance e agências de patrimonialização cultural: uma experiência de pesquisa (Sobral-CE)
}

\author{
Cleane dos Santos de Medeiros ${ }^{1}$ \\ Nilson Almino de Freitas ${ }^{2}$
}

\section{Introdução}

O presente estudo discute sobre a classificação da prática social da Dança de Rua/Street Dance, como patrimônio cultural, mais especificamente, tendo como delimitação a história do tempo presente e como método a prática de compartilhar experiências cotidianas com um grupo de dança denominado Street Dance - Jovens em Movimento - grupo este formado por jovens advindos da periferia da cidade brasileira de Sobral, localizada no norte do estado do Ceará.

Neste artigo, a discussão sobre patrimônio pretende transgredir um regime hegemônico naturalizado pela narração da monumentalização oficializada juridicamente pela lógica do tombamento promovida pelo estado, especificamente pelo Instituto do Patrimônio História e Artístico Nacional - IPHAN. Entende-se aqui que o Patrimônio não é só proteção de valores espirituais e materiais passados por gerações. É uma construção social sustentada em uma engenharia política e moral acionada por agentes que criam o espaço e o tempo no cotidiano, em conflito ou tensão com outras agências ${ }^{3}$. Diferentes grupos, através de suas artes, disputam pelo espaço do reconhecimento social em diferentes lugares e eventos da cidade, justificado por uma lógica que usa o tempo e as práticas cotidianas em relação com dinâmicas socioespaciais que falam de uma identidade que precisa ser confirmada socialmente em determinado campo de atuação.

Acadêmica do Curso de História pela Universidade Estadual Vale do Acaraú-UVA/Sobral-CE, Bolsista do Programa de Residência Pedagógica de História/CAPES - Edital 16/2018.

Professor Doutor da área de Antropologia da Universidade Estadual Vale do Acaraú-UVA/SobralCE, Coordenador do Laboratório das Memórias e das Práticas Cotidianas - LABOME, Coordenador do Programa de extensão Visualidades, Professor do Mestrado Acadêmico em Geografia da UVA - MAG, Pesquisador Associado do Pós-doutorado em Estudos Culturais do Programa Avançado de Cultura Contemporânea da Universidade Federal do Rio de Janeiro.

HERZEFELD, Michael. A place in history: Social and monumental time in a grita town. Princeton: Princeton Univercity Press,1991). 
No caso do Street Dance - Jovens em Movimento, grupo escolhido como foco desta discussão, percebe-se um movimento em busca da consagração, usando o discurso da identidade cultural relacionado a determinada espacialidade da cidade conhecida como "periferia". Este termo aparece como marco espacial para afirmar um desejo de identificação, junto com o nome do bairro onde atuam com mais frequência. Para Deleuze ${ }^{4}$, o conceito de desejo é o agenciamento de um conjunto de elementos que constituem o contexto do objeto supostamente referente. Não se deseja uma identidade, mas uma série de elementos que formam um conjunto relativo ao lugar, à posição, ao interesse e à imagem que estão "ao redor" do "ser" desejado e o reforçam.

Para entender a identificação desejada nesta concepção, devemos nos ater à engenharia social construída pelos agentes individuais para falar e agir em prol de um movimento de sua constituição que é constante e instável, dependendo do contexto de comunicação em que cada agente atua.

O movimento originário da prática do grupo Street Dance - Jovens em Movimento, denomina-se Hip Hop, que em sua tradução literal significa "movimentar os quadris" (to hip) e "saltar" (to hop). Uma vez que, historicamente, suas origens, como nos lembra Oliveira ${ }^{5}$, foram estabelecidas a partir do DJ jamaicano Kool Herc, que no final da década de 1960, através

222 de viagens realizadas ao Caribe e à África do Sul "descobriu cantos falados de grupos étnicos que se assemelhavam ao reggae". Sendo, pois, estas festas conhecidas como "sound systems", consequentemente foram levadas para o gueto estadunidense, mais especificamente para a cidade de Nova York, no bairro do Bronx no início dos anos de 1970, onde o músico norte-americano Afrika Bambaataa as reinventa na década seguinte, criando não somente $o$ termo Hip-Hop que atualmente caracteriza tal movimento e que resplandece por todo o mundo, mas todo um conexo sistema de troca entre seus pares que não enquadravam-se no padrão da época.

Nota-se que já não faz muito sentido pensarmos em um lugar de origem para esta manifestação cultural específica, já que é resultado de uma diáspora ressignificada no Caribe, África do Sul, Jamaica e EUA. Pensar em diáspora cultural faz lembrar que, a partir do século XX, adentrando o século XXI, duas vias devem ser chamadas à atenção como mediadoras da complexificação na tentativa de diferentes agentes de construção de identidades supostamente sólidas, estáveis, independentes e autônomas: a comunicação eletrônica e a facilidade de mobilidade promovendo e intensificando a migração.

DELEUZE, Gilles \& GUATTARI, Félix. Mil platôs: capitalismo e esquizofrenia. São Paulo: Editora 34, 1997, vol.4.

5 OLIVEIRA, Roberto Camargo de. Música e política: percepção da vida social brasileira no Rap. Dissertação apresentada ao programa de Pós-Graduação em História da Universidade Federal de Uberlândia - UFU. 2011. 
Como nos lembra Appadurai ${ }^{6}$, estas duas vias que facilitam as diásporas culturais, promovem transformações e são portadoras de sentido da distância cada vez mais próxima, mudando discursos cotidianos e favorecendo recursos de toda ordem de experiências possíveis para construção da identificação individual e grupal. Permite enredos sedutores do desejo pela identificação, criando plausibilidade para se pensar o grupo e o indivíduo como projeto social em curso a partir de marcadores históricos e espaciais que circulam globalmente e que são ressignificados localmente, reforçando esforços e desejos pela identificação. Neste movimento, pouco se mantém incólume a estável, ao mesmo tempo em que dão potência a esforços pela busca da estabilidade identitária. Neste sentido, as práticas culturais podem ser percebidas como sinergias de movimentos e agências acompanhadas de tensão, fora de "cordões sanitários" de "purismos" espaciais e temporais. São obras da imaginação criativa, nem totalmente emancipadoras, apesar de pretenderem ser em alguns contextos, nem inteiramente disciplinadas, apesar de passarem por crivos socialmente agenciados, neste sentido provocando tensão e conflitos entre estes movimentos que aparentemente são contraditórios. São buscas pelo reconhecimento e pelo espaço de ação contestadora em que procuram anexar o global às suas próprias práticas e esforços pela identificação, acompanhadas de uma memória e de desejo, criando biografias em ritmo de improvisação, ao mesmo tempo que força estabilidade. Neste caso, apesar de parecer estrangeirismo, o street dance fala do local, do lugar, de uma história especial e de diferenças culturais. É um movimento dualista que, ao mesmo tempo, se insere no global, parecendo imitação de manifestações que supostamente seriam de outros lugares, assim como tende a reivindicar uma identidade própria, exclusiva, independente e autônoma na periferia e no bairro onde atuam.

É importante salientar que, neste contexto de diáspora do Hip Hop aqui esboçado, que lembra a chegada em Nova York, encontrava-se explícito um sistema de trocas e interações entre estes sujeitos, imigrantes latino-americanos, jamaicanos e afro-americanos existentes no limiar da cidade. O Hip Hop surge, desta maneira, a partir de um sistema conexo de luta e resistência em prol do garantido direito de viver e morar na cidade. Como Santos ${ }^{7}$ nos fala, o contexto econômico, social e de desestruturação urbana pela qual passavam as principais cidades do mundo faziam com que naquele momento da década de 1970 houvesse crescentes crises econômicas, sociais e de desestruturação urbana. Sendo, pois, erguido neste cenário de desordem, insegurança e instabilidade social palco para as reivindicações juvenis, possibilitado o

APPADURAI, Arjun. Aqui e agora. In: Dimensões culturais da globalização. Editora Teorema: Lisboa, 2004, 11-40.

SANTOS, Anderson Luís Mateus. Danças Urbanas: das Ruas aos Palcos. 2014. 50f. Monografia (graduação em Dança - Licenciatura) - Curso de Dança - Licenciatura, Universidade Federal de Pelotas, Rio Grande do Sul, 2014. 
resistir e o organizar-se contra todas aquelas mazelas que diariamente assolavam a vida daqueles que ali habitavam. Para Souza ${ }^{8}$, é deste modo que são criados nos guetos inúmeros espaços de sociabilidade, mobilização política e de produção de uma identificação coletiva, sendo estes manifestos a céu aberto, como em praças e/ou quadras de esporte, ou seja, a rua em suas diversas variantes. Posteriormente, as práticas do Hip Hop passam a ocupar outros espaços da cidade, como bares, clubes e boates. Porém, é apenas com o advento da apropriação de técnicas de cunho musical e visual que se vê possibilitado o reconhecimento e propagação mundial.

Já para Fochi ${ }^{9}$, o street dance chega-nos, diferentemente do seu surgimento nos Estados Unidos, em espaços centrais das cidades de São Paulo e do Rio de Janeiro, mais especificamente em frente ao Teatro Municipal e posteriormente na Rua 24 de Maio. Uma outra diferenciação aparente refere-se ao porquê do dançar, visto que aqui no Brasil visava-se primeiramente a diversão e a busca por autoestima. Já que havia-se uma grande diversificação da sociedade e da forma como recrear-se, como defende Del Priore ${ }^{10}$, sendo pois, a partir de códigos culturais específicos que realizava-se a interação na cidade.

Uma vez que foi a partir destes contextos que o movimento foi propagando-se e desenvolvendo-se em todo o nosso país, ganhando, desta forma, mais visibilidade com os videoclipes e músicas do cantor de POP Michael Jackson, que a partir da década de 1980 estavam bastante presente nas mídias. Contudo, quando a dança parou de fazer-se tão presente nestes meios midiáticos, somente aqueles que tinham consciência do que representava este movimento é que continuaram a desenvolvê-lo e incorporá-lo ao cenário sociocultural das periferias paulistanas. Sendo, pois, neste contexto desenvolvido e consequentemente disseminado por todo o país.

Podemos afirmar que, com a experiência de campo em Sobral, comparando com a forma como o Hip Hop se apresenta no Brasil, este movimento, que ganha caráter de contestação e reivindicação juvenil, apresenta contornos semelhantes em alguns aspectos e diferentes em outros nas cidades brasileiras, e Sobral não é exceção.

O leitor deve entender que o recurso usado para este detalhamento a ser feito neste artigo é a de experiências cotidianas compartilhadas com os interlocutores, registradas em diário de campo. Acompanhamos, com o uso do recurso videográfico e fotográfico, algumas atividades do grupo, como

\footnotetext{
SOUZA, Gustavo. Novas sociabilidades juvenis a partir do movimento hip hop. Animus: Revista interamericana de comunicação midiática/ Universidade Federal de Santa Maria, Centro de Ciência Social Humanas. - vol. III. n 2. Santa Maria, NedMídia, 2004.

9 FOCHI, M.B. Hip Hop Brasileiro: Tribo urbana ou movimento social? Revista Facom, Rio de Janeiro, v.17, nº 1 ,Jan./jun., p. 61.

10 DEL PRIORE, Mary. Histórias da gente brasileira, volume 3: Republica memórias (1889-1950). Rio de Janeiro: LeYa, 2017.
} 
ensaios, apresentações públicas, conversas informais, festas, e registramos conversas individuais. A experiência contemporânea com o tempo, acionada nesta pesquisa, mostra uma política de memória que liga a ideia de patrimônio cultural a um presente que se sustenta por uma construção do passado que possa justificar dinâmicas atuais. Pensamos que discutir sobre patrimônio não se refere só a um passado factual estável, mas a um presente onde os diferentes agentes que disputam nas relações sociais o reconhecimento social, fazem escolhas de referenciais e, a partir deles, cria o seu passado. É como se fosse uma confluência de temporalidades, onde o limite entre passado, presente e futuro se confundem, se misturam em uma sinergia muito pouco estável que fala muito mais de desejos, de potências e de fluxos, do que de mapas fixos que permitem entender o tempo de forma linear e em sequências lógicas inteligíveis.

Segue nossa tentativa de descrever a experiência e arrumar o tempo histórico a partir da forma como fomos afetados na dinâmica cotidiana compartilhada com nossos interlocutores.

\section{Diário de pesquisa e percepção cotidiana sobre o patrimônio cultural: o grupo Street Dance - Jovens em Movimento}

A pesquisa é iniciada por volta do dia 25 de maio de 2016, sendo um dos proponentes deste artigo o orientador do projeto, e a outra, bolsista de Iniciação Cientifica da Fundação Cearense de Apoio ao Desenvolvimento Cientifico e Tecnológico (FUNCAP), no projeto intitulado "Narrativas e Imagens: Bairros e cidades possíveis em Sobral/CE", aprovado no edital $\mathrm{n}^{\circ}$ 09/2015-BIP/FUNCAP, subsidiado por meio do Programa de Bolsas de Produtividade em Pesquisa, Estímulo à Interiorização e à Inovação Tecnológica - BPI. A bolsista viu a possibilidade de realizar uma pesquisa na cidade de Sobral, mais especificamente em um bairro periférico: o bairro do Padre Palhano. Posteriormente, nas caminhadas, na fronteira entre este bairro e o Sumaré, também periférico, encontramos o grupo de dança denominado Street Dance - Jovens em movimento que, segundo um dos nossos interlocutores, há 12 anos atuava no bairro do Sumaré. No dia 15 de janeiro de 2018, a bolsista teve a oportunidade de acompanhar oficialmente o início de um ano de ensaios do grupo. Outras duas companheiras de pesquisa, Joana Darc e Dedita Ferreira, uma sendo curiosa pelo tema e a outra bolsista, também vinculada a projeto semelhante, coordenado pelo mesmo orientador.

Neste primeiro contato com o bairro Sumaré, não tínhamos ainda pontos de referências nem marco espacial que pudesse nos orientar nas caminhadas. Apenas conhecíamos o percurso que leva à linha do VLT. Olhávamos para os lados a procura por pontos familiares, porém não apareciam. Naquele momento, via-me distante de todos os pontos ditos referenciais 
da cidade. Seguindo em direção à Escola Maria José Parente Prado, local onde realizavam-se todos os ensaios do grupo, deparamo-nos com calçadas cheias de pessoas a conversar, outras andando nas ruas, alguns bares (bodegas) abertos. Seguindo caminho, perguntando a um e a outro, mesmo que aparentemente perdidos naquele local, íamos avançando, nos encontrando ao perguntar para os moradores daquele bairro qual caminho seguir.

Ao subir o que parecia um alto, seguimos em direção a uma praça. Acompanhando o percurso de algumas pessoas, conseguimos chegar ao nosso destino final, porém, éramos as primeiras, um pouco antecipadas, talvez. Os ensaios ocorriam no pátio da escola, que naquele tempo, seus alunos encontravam-se de férias.

Pouco a pouco os bailarinos começavam a chegar, o que nos possibilitava iniciar um diálogo. Foi assim que iniciaram indagações acerca da universidade, perguntava-nos sobre experiências, questionando acerca dos nossos cursos e das disciplinas a serem cursadas, mostrando que, na prática da pesquisa, não é só o pesquisador que faz a pesquisa, são eles também que investigam o pesquisador. Neste momento, explicamos como chegamos lá, nossos intuitos e o querer por estudar e compartilhar vivências com o grupo deles e delas, procurando realizar uma produção audiovisual, método e possível repercussão da referida pesquisa.

Posteriormente a esta breve conversa, chega Pâmela Nara, a presidenta do grupo e principal coreógrafa. Nos recepcionou calorosamente, nos falou sobre um evento, para o qual o grupo havia sido convidado e sua importância para todos que ali estavam. O referido evento ocorreria no bairro, a já conhecida por eles Feira de Economia da Agricultura Familiar de Sobral - FENESUL. Por tratar-se da primeira apresentação do ano, havia-se todo um cuidado e um capricho especial. Pâmela informou a todos que pediria um momento de fala para que pudesse relatar as conquistas decorrentes da temporada anterior. Concluída a fala, reforçou a importância do evento e que todos ali deveriam dar o seu melhor. Percebia-se o cuidado para com o que é mostrado e principalmente o que eles representavam para o bairro em questão, mencionado por ela como marco referencial de suas vidas e de suas artes. Desta forma, as músicas escolhidas foram: "Vai malandra", da cantora Anitta, "End of times", da cantora Beyonce, e Low (feat. T-Pain), do cantor Flo Rida.

É importante salientar a não utilização de caixas de som para a realização deste primeiro momento de ensaio. Neste momento, procurava-se não atrapalhar ou desconcentrar o subgrupo ao lado. Entre uma brincadeira e outra, a sintonia entre eles e elas era visível. Brincavam, riam, "competiam" entre si, mas ajudavam uns aos outros. Posteriormente, a realização de todo o repasse das músicas internacionais de forma separada, ambos os subgrupos se pro- 
puseram a se apresentar. Desta maneira, o subgrupo do Jhonatan sentou-se enquanto o da Pâmela iniciou a apresentação. Desta mesma forma, outro subgrupo o fez. Após estas apresentações iniciou-se, em conjunto, o repasse da música "Vai malandra", de domínio geral do grupo.

Após uma semana árdua de ensaios, chega o dia da apresentação na Praça do Sumaré. As ruas encontravam-se cheias de pessoas. Tinha mais gente do que nos dias anteriores, várias barracas vendendo comidas e bebidas, dentre elas uma do grupo Street, que procurava arrecadar dinheiro para o próximo espetáculo.

Ao iniciar a apresentação, as pessoas gritavam o nome dos integrantes. Um a um eram identificados pelos moradores do bairro. O pertencer àquele local era explícito como marcador importante de identificação coletiva do grupo. Compreendia-se assim a importância daquela apresentação para os integrantes como moradores, dançarinos e pertencentes àquele lugar, ressaltando-se aquilo que mais gostam de fazer: dançar.

Identificando-se com aquilo que era apresentado, as pessoas que ali estavam interagiam com as músicas, com os ritmos e coreografias. De forma alternada, os dançarinos da família Street Dance iam apresentando o resultado de toda a dedicação da semana, dos ensaios, do tempo disponibilizado para aquela apresentação.

Ao concluir com a música da cantora POP Anitta, "Vai malandra", a presidenta Pâmela inicia sua fala.

Gente, eu acho que desde que eu era pequena, que eu evoluí pra ser pequena, né. Agora sou grandona. O Street Dance vem se apresentando na FENESUL e há 12 anos eu como uma grande protagonista de movimentos culturais dentro da nossa comunidade me espelho em coisas boas, então, gostaria de agradecer a todos e principalmente na pessoa do Zezinho do Sumaré, que há anos vem nos apoiando ${ }^{11}$.

Posterior a esta apresentação, iniciou-se um novo ciclo, com mais ensaios, dedicação e empenho. Procurando manter o posto adquirido no ano anterior, pois como Pâmela ressalta,

Desde 2016, que a gente é considerado como o melhor grupo Pop da região norte. Hoje o Street Dance não é só conhecido em Sobral, mas ele é conhecido nas regiões vizinhas, porque a gente participa de competições, de festivais e em 2016 entrou com um espetáculo que foi "Se o mundo fosse acabar o que

11 NARA, Pâmela. (Depoimento, 2018). Sobral-Ceará, Laboratório das Memorias e das Práticas Cotidianas. Universidade Estadual Vale do Acaraú, Depoimento de História, 2018. 
você faria, Amaria, dançaria ou Luxaria? " tivemos ai 10 apresentações foram 9 títulos de $1^{\circ}$ lugar e um de vice-campeão e ano passado (2017) a gente teve o espetáculo "A batalha os donos da rua" que também favoreceu. Foram dez apresentações, cinco de $1^{\circ}$ lugar e cinco de vice. Conseguindo em si o Street ainda ficar no pódio de melhor grupo Pop da região Norte, pronto $^{12}$.

A narrativa acima mostra o esforço dos agentes individuais integrados em um coletivo de afirmar seu vínculo a um lugar através do movimento de seus corpos em dança, que só superficialmente parecem não ter relação com o lugar, influenciados por estrangeirismos, ou não ser próprios de uma cultura específica relacionada ao bairro e à cidade. Falar sobre o seu lugar e sua atividade são elementos que se completam e parecem fortalecer o desejo identitário que cria uma unidade no grupo e o vincula ao Sumaré. Dois movimentos convergem nesta narrativa: um que fala de um reconhecimento social dentro do bairro que precisa, ao mesmo tempo, ser reconhecido fora dele também para reforçar o agenciamento pelo fortalecimento de vínculo identitário. Neste caso, a identidade coletiva mostra muito pouca estabilidade, pois carece sair de seu território, supostamente seguro, ao mesmo tempo que cobra uma confirmação fora e dentro dele, para poder entrar e serem reconhecidos socialmente por seus pares.

Os esforços pela confirmação de um desejo de identificação com o bairro inserem a delimitação espacial do lugar, em território mais genérico denominado como "periférico". Por sua vez, dependendo de onde estão, este território de desejo identitário se amplia e se relaciona com a cidade, especialmente quando se apresentam fora dela. O desejo é segmentado em territórios que variam, dependendo de onde se apresentam, mas sempre o vínculo com o bairro acaba sendo mencionado, mesmo quando incluído nestas espacialidades mais amplas de "periférico" ou "sobralense", assim como em outros momentos "a região norte" é lembrada como delimitação territorial mais ampla.

Estes esforços também remetem a uma tradição a partir de um discurso que aponta uma história de "vitórias" ou, pelos menos, estar perto da vitória em competições extralocais e locais. O tempo também é marcado nas experiências pessoais que se "espelham" em uma espécie de tradição de protagonismo cultural dentro do bairro há doze anos, como mencionado no caso de Pâmela.

Logo nas primeiras vezes que começamos a conviver com o grupo, Pâmela e Patrick fizeram questão de ressaltar que o Street Dance era mais do que

12 NARA, Pâmela. (Depoimento, 2018). Sobral-Ceará, Laboratório das Memorias e das Práticas Cotidianas. Universidade Estadual Vale do Acaraú, Depoimento de História, 2018. 
um grupo de dança existente num bairro da cidade de Sobral. Para eles, o Street era uma família, família Street Dance. E que a dança para esta família era mais do que simplesmente dançar, era, pois, um processo de valorização da identidade daqueles jovens que fazem parte dessa família. Quando Pâmela fala sobre a identidade do grupo, fica evidente que a dança é usada como um instrumento de valorização do ser humano e do lugar no qual estão inseridos.

Hoje o Street Dance não só agrega dançarinos do nosso bairro, mas ele tem dançarino de vários outros bairros, como do Centro, Caiçara, Terrenos Novos, Vila União, Sumaré e adolescentes lá do Santo Antonio. Então, a origem do grupo surgiu numa associação que existia no bairro. Era chamada "associação Cara Preta", que hoje esta associação ela é fechada devido usar recursos financeiros, e ai, a ideia inicial começou trancada eu e quatro outros, três dançarinos que não dançam mais. Trancado em um quarto escutou a música "My Humps", do The Black Eyed Peas. Ai a gente teve toda a ideia de montar aquele grupo porque aqui no bairro não tinha nenhum grupo que fizesse esse movimento. Então a gente montou o Street Dance, aí tivemos nossa primeira apresentação lá na praça e desde então o grupo foi surgindo ${ }^{13}$.

As coreografias do grupo são montadas por três voluntários, sendo estes Pâmela Nara, Patrik Montgomery Espósito e Jhonatan Ripardo. Por meio desta fala de Pâmela, podemos perceber que na ideia do surgimento do grupo já continha o desejo de que o Street Dance pudesse colaborar com a criação de um movimento no bairro e que este contribuiria com a valorização deste lugar na cidade a partir do reconhecimento social que buscavam com sua expressão artística. Por isso, torna-se importante ressaltar que a dança passa a ser ressaltada como uma cultura que pode e precisa ser praticada não só como uma forma de salvação de jovens do "mundo das drogas", como alguns entendem, e além de uma mediação para uma profissão, mas também como marco de identificação coletiva. A ideia de família, apontada por Pâmela, reforça a ideia de constituição de vínculos e fortalecimento de um modelo de relações de sociabilidade existentes entre os membros do grupo Street Dance.

\section{Considerações finais}

Ao nos inserirmos no grupo, passamos a frequentar os ensaios de dança que acontecem durante a semana. É importante salientar que inserir-se em

13 NARA, Pâmela. (Depoimento, 2018). Sobral -Ceará, Laboratório das Memorias e das Práticas Cotidianas. Universidade Estadual Vale do Acaraú, Depoimento de História, 2018. 


\section{Nossa Gente,}

um grupo já formado e estar presente no cotidiano deste grupo é se inteirar de suas relações com o mundo. Porém, é somente neste contexto temporal do cotidiano que conseguimos ver sentido na equivalência entre atividade cultural que parece ser estrangeira e patrimônio cultural, já que remete a um desejo por uma identidade coletiva, fala de uma história, de uma tradição e tenta mostrar e reforçar o vínculo com o lugar, reforçando também um sentimento de pertença. Claro que a promessa de fazermos um documentário sobre o grupo ajudou na aproximação e excitou uma performance voltada para construção da cena fílmica sobre estas questões. Pretendemos, se é que seria possível fazer o contrário, que os processos de produção não fossem momentos descolados do cotidiano do grupo, sendo componentes importantes para incentivo de performances e agências para afirmar uma narrativa que configure experiência, competência e uma prática social que visa fortalecer desejos de vínculos coletivos e identitários.

As cenas registradas foram resultantes de experiências compartilhadas com nossos interlocutores. Claro que somente é uma impressão de uma prática cultural "inventada", no sentido criativo do termo, a imagem registrada e a narrativa gravada. Não é mentira, é uma experiência de construção e prática de sentido que inclui a transformação ${ }^{14}$. Nós, eles e elas, em conjunto vivemos experiências e o resultado está sendo um texto e, futuramente, um filme, resultantes de afecções, no sentido de "ser afetado" por agências pouco previsíveis e muito menos controláveis, que promovem uma revisão epistemológica, cognitiva e subjetiva que estimula a imaginação criativa de um relato da experiência produzindo uma alteridade discursiva que visa causar um efeito no leitor. Este texto mostra como fomos afetados pela experiência. Foi um convívio dialógico com os integrantes do grupo, possibilitado a construção da amizade, valorizando as trocas de experiências de mundo, compartilhando saberes que nem sempre concordamos, fundando o respeito mútuo, relacionando-se a partir de um modelo de sociabilidade onde não podemos desconsiderar a presença e influência da câmera.

A discussão sobre patrimônio cultural proposta, portanto, deve ser pensada como resultante de uma relação entre seres humanos instalados em uma cultura de sociabilidade que não quer necessariamente afirmar uma relatividade de uma verdade sobre o conceito, justamente porque o relativismo, como lembra Castro $(2002)^{15}$, é relação. O que nossa reflexão realiza é um perspectivismo que afirma a relativização do conceito de patrimônio cultural a partir de um exercício de indução que acompanha os afetos causados pela ausência de possibilidade de falar da relação como fatos estáveis, substantivos e objetivos. Não é explicação, nem interpretação. É uma experimentação de sentidos compartilhados. A expressão cultural, entendida 
como efeito de uma tradição, vínculo identitário e relacionado a um lugar próprio que a caracteriza, é resultado da condição do campo perceptivo atual dos pesquisadores e sua existência é garantida pela virtualidade de um outrem percebido, garantindo uma presença deste outrem como um possível. $\mathrm{O}$ sujeito que promove a agência e tenta garantir a necessidade de construção de um modelo de convivência mútua através de sua expressão artística é um efeito e não causa da análise objetiva, se é que ela existe, a partir de uma convivência de trabalho de campo que serviu como fonte. O não visível por alguns, subsiste como real, ou experimento de real, e ganha visibilidade para o leitor a partir da agência dos autores deste texto. O interlocutor pensa como pesquisador também, para fazer a mediação entre o desejo e o efeito no seu observador. Eles são parceiros no trabalho de campo e procuram afetar o pesquisador de uma determinada forma.

Neste sentido, a cultura que se quer como patrimônio não existe fora da expressão relacional entre os diferentes agentes no processo de pesquisa. A cultura, em geral, é uma variação relacional. Não é um ente estável, fixo, independente e definitivo. É movimento. Por isso que não é possível termos um contorno visível e óbvio de seus limites, já que as suas variações se relacionam, se encontram, se desencontram, territorializam e desterritorializam, criando tensões que pedem uma confirmação dos agentes e luta constante pelo seu território moral e político, no sentido de confirmar uma tradição e um patrimônio. Esta confirmação é a busca pelo reconhecimento e consagração de suas práticas que não podem ser expressas somente no território que já conquistaram. Têm que ser mostradas fora dele para que, no retorno, possam expressar sua importância na conquista pelo reconhecimento extralocal, o que acaba sendo importante para a consagração local. Este exercício serve para levarmos a sério uma velha narrativa de que "a cultura e a sociedade estão em constante movimento". Este é o experimento que pretendemos mostrar aqui: acompanhar um movimento e colaborar com ele. 



\title{
19. Ambivalências poéticas nas canções de Belchior - a ida e o regresso
}

\author{
Francisco Sávio Barbosa do Nascimento ${ }^{1}$
}

\begin{abstract}
Quando eu ganhava esse mundo de meu Deus
Fazendo eu mesmo o meu caminho

Por entre as fileiras do milho verde

Que ondeia, com saudade do verde marinho' ${ }^{2}$.
\end{abstract}

\section{Introdução}

A música é um ente artístico inerente da humanidade e traz consigo valores culturais e políticos que reverberam as intencionalidades no ofício artístico de composição e interpretação, perpassando então pela sonoridade, a intelectualidade humana como "um canto torto" que "corta a carne" e adentra no íntimo do indivíduo, que por sua vez reage com uma pluralidade de sentimentos decorrentes da reprodução da obra poético-melódica. Tal processo pode então atuar como mecanismo revolucionário e transformador de todo um imaginário social de várias gerações a partir da mensagem da canção e de como é passada, musicalizando o cotidiano. É sobre essa capacidade de transformar em música aspectos simbólicos da realidade que discutiremos as produções poético-musicais do artista sobralense Antônio Carlos Belchior, onde se apresenta nas linhas e entrelinhas de sua obra como sujeito melopoético ${ }^{3}$, nas composições descrevendo as aventuras de tentar oportunidade em outra região, se reagindo com perplexidade ao se deparar com "o novo", como também o saudosismo de um indivíduo desterrado que anseia o regresso.

Nesse sentido, trabalharemos com o conjunto de análise fonográfica de duas canções de Belchior - "Fotografia 3 4 "" e "Princesa do Meu Lugar"5,

Graduando no Curso de Licenciatura em História pela Universidade Estadual Vale do Acaraú-UVA. BELCHIOR, Antônio Carlos Gomes. LP Coração Selvagem. In BELCHIOR. Galos, Noites e Quintais. São Paulo: WEA Discos Ltda., 1977a. f.6.

O sujeito melopoético pode ser entendido como quando o compositor tem a ação de se colocar dentro da canção como participante daquela trama ou daquela história.

BELCHIOR, Antônio Carlos Gomes. LP Alucinação. In BELCHIOR. Fotografia 3X4. São Paulo: Polygram, 1976a. f.9.

VALBUENO, Eduardo. YOUTUBE - Belchior - Princesa do meu lugar (Programa Som Brasil).12 abr. 2012. 3min. 48s. Disponível em: <https://youtu.be/FaY55w6PwRQ> Acesso em: 10 out. 2018. A música é de composição de Belchior, mas não há registros de gravação em seus discos, somente havendo registro em uma apresentação do artista no programa Som Brasil e que só foi disponibilizada a partir dos documentos de Jorge Melo, amigo do cantor. 
dialogando com produções historiográficas, entrevistas e relatos que nos auxiliarão a pensar significados históricos extramusicais que envolvem a composição, partindo do fenômeno diaspórico que levou vários artistas a migrarem do Nordeste para os grandes centros urbanos do eixo-Sul na década de 1970, em busca de visibilidade e espaço no mercado da indústria fonográfica brasileira.

\section{A música cearense em um contexto diaspórico e a indústria fonográfica brasileira}

O Nordeste do Brasil possui um histórico marcante de movimentos migratórios decorrentes de inúmeros motivos pontuais de cada estado, sejam eles sociais, econômicos ou políticos, o que fez e faz com que uma massa considerável de pessoas se desloque de "sua terra", levando consigo a esperança de alcançar melhores condições de vida e subsistência em outras regiões que aparentemente poderiam lhes proporcionar tais anseios. Tal fluxo migratório esteve presente em vários momentos da história do Ceará, e não somente ocasionados pelo fenômeno periódico da seca, mas também por inviabilidade de projeção que tange a classe artística e, especificamente, a música.

O Sul do Brasil, nesse sentido, atuou como reduto de grandes nomes da música popular brasileira, e isso se deu graças a uma influência hegemônica na produção musical no início do século XX, pois era essa região que possuía a maior concentração de estúdios de gravação e de potenciais investidores que projetavam a figura do artista e que dariam a visibilidade necessária para tornar conhecidas suas obras. No entanto, uma das exigências naturais da indústria fonográfica era o deslocamento do artista, no caso dos nordestinos, a se deslocarem das "suas terras" para o "Sul Maravilha"6. Sobre isso, Haudenschild destaca três gerações, que num período de aproximadamente 40 anos fizeram esse percurso:

Ao remontarmos às décadas de 1930 e 40 , podemos identificar uma $1^{\text {a }}$ geração diaspórica nordestina em nossa canção popular sendo "liderada" por Dorival Caymmi (1938) e Luiz Gonzaga (1939), na qual se inclui, entre muitos outros, os paraibanos, Jackson do Pandeiro (1954) e Sivuca (1955), o pernambucano, Dominguinhos (1954), e o maranhense, João do Vale (1950). Assim como uma $2^{\mathrm{a}}$ geração diaspórica composta, entre outros, pelos baianos, Tom Zé (1965), Gilberto Gil (1965), Caetano Veloso (1965) e Capinan (1964), o piauiense

Termo cunhado a partir das charges do cartunista Henfil nas tirinhas do "O Graúna", que explicava, a partir das críticas políticas a partir do humor do cartum, o fenômeno de migração dos nordestinos para o Sul. 
Torquato Neto (1962) e, bem antes deles, o paraibano Geraldo Vandré (1952), que chegou ao Rio com seus pais ainda na juventude (NUZZI, 2015). E uma 3a geração diaspórica, composta por Alceu Valença (1971), Geraldo Azevedo (1971), Fagner (1971), Belchior (1971), Djavan (1972), Ednardo (1972), Vital Farias (1975), Zé Ramalho (1976) e Lenine (1979), entre uma lista infindável de outros artistas ${ }^{7}$.

A construção da trajetória diaspórica dos artistas, conforme nos explica Haudenschild, se deu gradualmente com o deslocamento dos desbravadores nordestinos que atuavam como produtores culturais em suas regiões e agora precisariam se reafirmar enquanto profissionais da música, com o objetivo de alcançar um espaço no mercado musical já consolidado, e então montar um público ouvinte seguindo as predisposições impostas pela indústria fonográfica para se entrar em cena nacional. Nesse sentido, desde Luiz Gonzaga, a música nordestina apresentou-se com um caráter imbricado do regionalismo percebido nas canções e na montagem do discurso das letras do sertão, como um espaço de memórias/mnemônico representando o cotidiano do sertanejo com seus problemas sociais, a violência, e especialmente o fluxo migratório entre o sertão e a metrópole. Os artistas que vieram após esse período também reverberaram esse comportamento, reproduzindo em alguma de suas canções o mesmo discurso, tomando como referência a obra de Luiz Gonzaga, sendo herdeiros culturais. ${ }^{8}$

Podemos destacar dentre esses artistas classificados cronologicamente em gerações as figuras dos cantores e compositores Fagner, Ednardo e Belchior, todos advindos do Ceará após o Tropicalismo ${ }^{9}$ da década de 1970, período do auge da indústria musical brasileira, que traçaram o mesmo percurso de vir para o Sul. Sobre isso, Fagner nos fala que:

A maneira como nos olham e definem: somos os paraíbas das construções, os paus de arara das feiras de São Cristóvão. Os famintos. E aí chegamos e enfrentamos isso como se estivéssemos entrando em outro país. É uma batalha desumana essa de chegar e conquistar um lugar ao sol no meio de tanta fera. Eu vim disposto a arriar a minha bagagem e não para levá-las de volta para $\operatorname{casa}^{10}$.

HAUDENSHIELD, André Rocha Leite. "Lamento sertanejo": experiências diaspóricas e a reinvenção das identidades culturais nordestinas na música popular brasileira nos anos 1960 e 1970. Brasília, XXIX Simpósio Nacional de História Contra os Preconceitos: História e Democracia. 2017, p. 4 (Anais).

8 HAUDENSHIELD, André Rocha Leite. Ibid. 2017, p. 2 (Anais).

9 Movimento de corrente artística e política surgido no final dos anos 60 e que revolucionou a Música Popular Brasileira, tendo como principais articuladores os artistas Caetano Veloso, Gilberto Gil, Gal Costa, entre outros.

10 MEDEIROS, Jotabê. Belchior - Apenas um rapaz latino-americano. São Paulo: Todavia, 1aed. 2017.p. 43. 
Não era fácil, então, sair da região de origem e ir enfrentar o "novo" em uma região que estava além da realidade dos músicos, pois havia dificuldades que tornariam todo o processo de efetivação musical gradualmente doloroso e desafiador. No entanto, a vinda desses grandes nomes da música cearense se efetivou, mas possuíam uma atuação com conotação grupal, realizando até mesmo produções conjuntas em disco, sendo então denominados de O Pessoal do Ceará.

O Pessoal do Ceará foi um nome alegre e até irônico. É a designação vulgar de "grupo", que na realidade englobava um sem número de pessoas que geracionalmente estavam envolvidas com o projeto da música aqui, não correspondia ao objetivo maior. O caráter mais interessante da nossa geração foi de termos incorporado como espírito diretor de nossos projetos, às coisas naturais, não exatamente como objeto de consumo ${ }^{11}$.

A importante consideração de Belchior sobre o movimento de música cearense nos faz entender que, embora os artistas possuíssem essa aparência grupal, cada qual dos integrantes possuía suas singularidades e estilos musicais múltiplos, sendo essa formação consagrada na gravação do disco Pessoal do Ceará - Meu Corpo Minha Bagagem, em $1972^{12}$, que serviu de aporte para a inserção desses artistas no quadro nacional da música popular e para cunhar o título do grupo referencial do Ceará, marcante de uma geração. Sobre isso nos fala Rogério:

Até hoje jornalistas, pesquisadores, amantes da música cearense, comunidades virtuais e sites associam o nome Pessoal do Ceará a esse grupo de pessoas inseridas no campo intelectual e artístico que produziram músicas, canções, poemas, entre outros, partido de lugares e referências estéticas comuns a todos eles e que implementaram concomitantemente um projeto de inserção nacional de suas obras ${ }^{13}$.

\section{Belchior, o menestrel do Ceará}

Belchior, cantor e compositor provindo da importante cidade interiorana de Sobral, localizada no noroeste do estado do Ceará, e como anteriormente falado, consagrou-se como um importante nome da música cearense, ascen-

\footnotetext{
PIMENTEL, Mary Aires. Terral dos sonhos - o cearense na música popular brasileira. Fortaleza: Secretaria de Cultura e Desporto do Estado do Ceará/ Multigraf Editora, 1994, p. 101.

12 EDNARDO. LP Pessoal do Ceará. Meu Corpo Minha Bagagem. São Paulo: Continental, 1972.

13 ROGÉRIO, Pedro. Pessoal do Ceará - habitus e campo musical na década de 1970. Fortaleza: Edições UFC, 2008, p. 28.
} 
dendo a uma posição de destaque no cenário da música popular brasileira. Construindo, assim, sua inesquecível obra poético-musical de excepcional riqueza intelectual com canções de significados "misteriosos e instigantes poemas concretos", possuindo mais de vinte discos gravados. Com musicalização e timbre singular em sua performance interpretativa, com "a voz áspera e seca, 'como as de um vaqueiro do sertão"'14, e que tinha no transcorrer dos seus versos referências e influências literárias de vários autores. Por isso, suas canções causam um impacto instigante capaz de formular várias questões que levam um contingente numérico expressivo de produções de pesquisa acadêmicas sobre sua obra e várias produções bibliográficas sobre sua vida. Conforme nos descreve Rogério ${ }^{15}$ em sua produção sobre o Pessoal do Ceará, a formação acadêmica de Belchior foi transdisciplinar, sendo a sua primeira formação básica no Colégio Sobralense, ainda na cidade de Sobral, até ir para a Convento dos Frades Capuchinos, em Guaramiranga, onde se tornara noviciando nos estudos religiosos, pois era o caminho mais fácil de um membro de família humilde do interior conseguir ingressar em um curso de Filosofia. E, conforme fala o próprio cantor: "Eu nasci em Sobral e creio que espiritualmente eu devo tudo a essa cidade. Foi lá que eu vi as pinturas das igrejas, foi lá que eu corri atrás das bandas de música, foi lá que eu ouvi os serviços de autofalantes" ${ }^{\prime 1}$. Sobral será o norte de sua formação musical, rica de sons e de cores que preencheram a memória de um jovem rapaz que iria ganhar o mundo.

No entanto, Belchior não prosseguiu na carreira eclesiástica. Partindo com sua família para a capital, estudou no Liceu do Ceará até prestar vestibular para o Curso de Medicina na Universidade Federal do Ceará - UFC, lugar onde o ambiente acadêmico e a vida boêmia noturna proporcionaram suas primeiras experiências musicais em festivais internos da universidade.

Toda essa trajetória acadêmica de Belchior rendeu-lhe influências que modularam seu jeito de cantar, sua visão de mundo e a sua filosofia de vida, tendo uma posição de destaque dentre os artistas que compunham o movimento do Pessoal do Ceará, como um cantor de repercussão nacional. Sobre essa fase de Belchior, nos fala Ednardo:

A admiração por Belchior, no entanto, crescia entre os colegas. 'Todo o Pessoal do Ceará considerava Belchior um hábil e atento poeta letrista, com belas melodias, dono de uma voz potente e bem característica, com uma obra musical perene na música popular brasileira, o que também é atestado por importantes interpretes', afirmou Ednardo ${ }^{17}$.

${ }_{14}$ MEDEIROS, Jotabê. Belchior - Apenas um rapaz latino-americano. São Paulo: Todavia, 1aed. 2017.p. 57.

15 ROGÉRIO, Pedro. Pessoal do Ceará - habitus e campo musical na década de 1970. Fortaleza: Edições UFC, 2008, p. 41.

16 CENTRO CULTURAL BANCO DO NORDESTE, YOUTUBE: 1/5 Belchior - Programa Nomes do Nordeste. 10min. 37s. Disponível em: <https://youtu.be/LQnlczSXUAQ>. Acesso em: 14 out. 2018.

17 MEDEIROS, Jotabê. Belchior - Apenas um rapaz latino-americano. São Paulo: Todavia, 1aed. 2017.p. 26. 
Nossa Gente,

Nossa História

o Ceará Republicano

\section{Um sujeito melopoético em suas canções}

As canções de Belchior retratam a pessoa do autor em um contexto autobiográfico, transparecendo a realidade, o cotidiano, as impressões de mundo, o modo em que se vive um nordestino fora de seu contexto de pertencimento, em um lugar desconhecido, cheio de desafios e novas descobertas de uma região promissora imaginada como um paraíso construído por diversas razões ideológicas e políticas de um dado governo. É que o "ser" nordestino ao se deparar com a realidade, aspecto bem presente no intertexto das canções, reage de uma forma perplexa diante das dificuldades encontradas, invocando sentimentos saudosistas de sua terra como lembrança ou memória de um refúgio.

Belchior, certa vez, ao ser questionado na entrevista pelo Professor Pasquale no programa Nossa Língua Portuguesa, na TV Escola, sobre o significado da canção "Como nossos pais"18, que foi eternizada na voz da impetuosa Elis Regina ${ }^{19}$, e que lhe consagrou o título de um melhores compositores da música popular brasileira, falou sobre as simbologias e significados que compõem os intertextos da canção:

Há um outro aspecto muito interessante que o autor não tem tanto distanciamento nessa canção. Eu como autor estou comprometido com o personagem dela e me identifico com aquele drama, com aquele conflito e também o contraste, não é? Que eventualmente o autor podia elidir e nesse caso não $f a z^{20}$.

Podemos, nesse sentido, analisar nos versos da canção de Belchior uma característica ímpar do estilo de composição já aludida no relato. Esclarece que em suas canções o autor, ao desenhar a trama e o desenvolvimento da sua obra poético-musical, se coloca como um sujeito participante, que se identifica e se impõe em um contexto histórico específico que reverbera um lócus de enunciação que o inspirou e condicionou seu ato de criação ${ }^{21}$. E, na fala do artista, podemos observar que essa relação de composição e artista está colocada como híbrido e interdependente que o compromete com todas as questões que estão colocadas na escrita que a compõe.

18 Além dessa canção, a cantora também incluiu "Velha Roupa Colorida", de composição de Belchior, no repertório do show Falso Brilhante em 1976.

19 A artista também gravou "Mucuripe" em 1972 no LP ELIS, sendo a canção de composição conjunta de Fagner.

20 MACHADO, Álvaro. YOUTUBE: Professor Pasquale entrevista o cantor Belchior - Nossa Língua Portuguesa (1996). 15 fev. 2016. 27min. 54s. Disponível em: <https://youtu.be/joB1oBzNSQI $>$. Acesso em: 14 out. 2018.

21 HAUDENSHIELD, André Rocha Leite. "Lamento sertanejo": experiências diaspóricas e a reinvenção das identidades culturais nordestinas na música popular brasileira nos anos 1960 e 1970. Brasília, XXIX Simpósio Nacional de História Contra os Preconceitos: História e Democracia. 2017, p. 4 (Anais). 
No entanto, a composição em si não basta, pois há aspectos estéticos que perfazem e que complementam a obra, descamando elementos extramusicais que estão nas entrelinhas da canção.

'O sentido sociocultural, ideológico e, portanto, histórico, intrínseco de uma canção é produto de um conjunto indissociável que reúne: palavra (letra); música (harmonia, melodia, ritmo); performance vocal e instrumental (intensidade, tessitura, efeitos, timbres predominantes); veículo técnico (fonograma, apresentação ao vivo, videoclipe $)^{22}$.

Portanto, para compreendermos a complexa obra de Belchior, destrinchando os significados que a envolvem, devemos apurar nossos sentidos de visão e audição, que estão além do risco do papel e que nos possibilita apreender e a formular uma infinidade de entendimentos polissêmicos sobre o que está além de música instrumentalizada. ${ }^{23}$ Pois é a obra antes de tudo uma produção poética, é sentimento e sensibilidade humana de um autor que conseguiu exprimir em sua produção poético-musical como compositor, e em sua performance como intérprete, no êxtase do exercício de reinventar sons e das notas emitidas, não se limitando à regra rígida da concretude da estrutura cifrada que conseguiu, através do som, transpor barreiras temporais e culturais que o perpetuaram como um sujeito de extrema erudição e $\mid 239$ sensibilidade com as coisas dessa vida.

\section{A polissemia das canções. Fotografia $3 \times 4$}

Belchior marcava com o disco LP Alucinação, em 1976, composto por 10 faixas pela gravadora Polygram, o segundo trabalho da discografia de sua então tenra carreira como cantor e compositor e que, sendo a música Fotografia $3 \times 4$ uma das músicas de maior destaque, ocupando a $9^{\circ}$ posição das faixas. Antes de tudo, é válido dizermos que não é objetivo do texto trazer interpretações definitivas, mas, como dito anteriormente, é apenas uma das interpretações possíveis sobre as canções, pois é necessário observarmos a letra para depois aludirmos questões sobre ela, dissertando sobre partes pontuais da obra que comporão uma das possíveis análises da canção.

Eu me lembro muito bem do dia em que eu cheguei Jovem que desce do Norte pra cidade grande.

Os pés cansados e feridos de andar légua tirana.

22 NAPOLITANO, Marcos. A História Depois do Papel. IN: PINSKY, Carla Bassanezi (org.). Fontes Históricas. São Paulo Contexto, 2010, p. 271. 
Ao começar a canção, Belchior tece uma narrativa em que se coloca como participante da canção, o eu lírico, o sujeito melopoético em forma de relato de vida, autobiográfico, como anteriormente falamos. Inserindo a si mesmo como agente participativo do movimento migratório que os artistas cearenses tiveram de enfrentar para vir do Nordeste para o eixo-Sul do Brasil na década de 1970, período de composição da música, em busca de projeção e reconhecimento artístico, parece estar explícita a dor de ser ainda tão jovem e ter de deixar sua terra em busca de um "novo" que estava longe do interior, em "légua tirana", afixado nos grandes centros urbanos, no caso de São Paulo e Rio de Janeiro.

\author{
Em cada esquina que eu passava um guarda me parava \\ Pedia os meus documentos e depois sorria \\ Examinando o 3/4 da fotografia \\ E estranhando o nome do lugar de onde eu vinha.
}

As dificuldades relatadas aqui por Belchior descrevem bem o estranhamento e a perplexidade em se deparar com um novo estado, estando na terra, no caso o Brasil, mas fora dela, no caso o Nordeste, tendo de se identificar como se fosse um estrangeiro completo, o que corroborou com a ação "guarda que o parava", no desconhecer de onde ele vinha, necessitando de um documento para ser identificado. Além da sua fisionomia, podemos pensar também do sotaque e das variações linguísticas que lhes serviam como definidores identitários.

Mas o que pesa no Norte, pela Lei da Gravidade, (disso Newton já sabia) cai no Sul, grande cidade. São Paulo violento... corre o Rio que me engana. Copacabana, a Zona Norte, os cabarés da Lapa, onde eu morei...

A parte em que podemos considerar como questão central na canção se encontra aqui, onde o autor passa a ideia de que a ida do Norte para o Sul seria um fenômeno sustentado pelas leis da física, o que em tese se enquadraria como um "determinismo social" e que teria realmente uma conotação de peso como um fardo (MOREIRA, 2015, p. 67). No tocante a situação das pessoas que optavam por esse caminho, passava desterrados, enfrentando os perigos de se morar na "grande cidade" e violentas como São Paulo dife-

${ }^{24}$ BELCHIOR, Antônio Carlos Gomes. LP Alucinação. In BELCHIOR. FOTOGRAFIA 3X4. São Paulo: Polygram, 1976a, f.9. 
rente da pacata rotina do interior, e coloca em xeque a imagem glamorosa como do Rio de Janeiro, como a "cidade maravilhosa", que seduz e engana quem vem com a realidade e que enfrenta dificuldade para morar, vivendo em constantes mudanças para lugares diferentes, coisa que esteve bem presente na vida de Belchior.

Mesmo vivendo assim não me esqueci de amar Que o homem é pra mulher e o coração pra gente dar Mas a mulher que eu amei não pode me seguir... Esses casos de família e de dinheiro eu nunca entendi bem. Veloso, "o sol (não) é tão bonito" pra quem vem Do Norte e vai viver na rua.

A expressão de "esquecer" e "lembrar" estão enfaticamente presentes na canção e, toda vez em que aparecem, exprimem uma relação com a dor pungente das coisas reais da vida. No entanto, aqui aparece como forma de contraponto ao que foi dito antes, explicando que mesmo passando por todas as condições adversas, jamais deixou de lado o que aparece como dever de amar, mesmo quem um dia ele amou, não pode seguir ou não quis seguir, como um problema pessoal crítico, a trajetória do artista, que reage com indiferença por isso não acontecer.

No final da estrofe destacada, Belchior faz uma citação contradizendo uma conhecida canção de Caetano Veloso, a música "Alegria, alegria"2526, colocando uma negação do "não" entre a frase original da canção que culmina com o sol, podendo representar as oportunidades e no tocante à composição e à trajetória de quem vinha do norte, a falta delas e que vai passar privações motivadas por elas.

A noite fria me ensinou a amar mais o meu dia E pela dor eu descobri o poder da alegria E a certeza de que tenho coisas novas pra dizer.

Nessa parte, o autor já se coloca como uma pessoa experimentada, que através das privações e das intempéries do tempo, aprendeu a valorizar as coisas do cotidiano, e que mesmo doendo, tudo isso lhe propiciou gradualmente uma contribuição para que agregasse em suas produções coisas "novas" para dizer em versos fortes e cortantes como faca.

A minha história é talvez igual a tua.

Jovem que desceu do Norte e que no Sul viveu na rua.

5 "Ela nem sabe, até pensei/Em cantar na televisão/O sol é tão bonito/Eu vou".

26 Canção difundida especificamente nos anos de maior repressão ainda na década de 60 a partir do movimento Tropicália, no qual Caetano foi um dos nomes mais expressivos. 
E que ficou desnorteado - como é comum no seu tempo.

E que ficou desnorteado - como é comum no seu tempo.

E que ficou apaixonado e violento como você.

Eu sou como você, eu sou como você, eu sou como você, Que me ouve agora.

Eu sou como você, eu sou como você, eu sou como você.

Fechando a parte final da canção com tonalidades apelativas que enfatizam pela repetição várias frases, Belchior objetiva a música diretamente ao ouvinte/telespectador, que ingere as palavras ao escutar a canção, dando a possibilidade de que talvez a condição em que o ouvinte se encontre seja semelhante ao do eu lírico da canção, no caso, Belchior na "descida do Norte", sendo a canção composta e divulgada na década de 1970, e como dantes falado, o fluxo migratório alcançou seu auge não somente no meio artístico, mas também nas demais classes sociais, que se encontravam e que coincidem com o jogo de palavras do autor como "desnorteadas" ou desterradas de seus locais de origem, podendo ser uma música de impactos identitários para não só uma geração, mas como também hoje, pois há muitos nordestinos que ainda comumente são como Belchior.

\section{Princesa do meu lugar}

A canção "Princesa do meu lugar"27 é uma das canções mais sentimentais de Belchior, tendo apenas um registro de sua interpretação em um programa televisivo chamado Som Brasil, pela TV Cultura, na apresentação do ator Lima Duarte, que começa a apresentação com uma introdução que fala da transitoriedade de um indivíduo que busca melhores condições de vida em outra lugar, "tendo saudade da terra estando na terra", e ressalta os nordestinos como um grupo que costumeiramente faz isso, e se nada der certo, há a opção do regresso.

\footnotetext{
Se me der vontade de ir embora, Vida adentro, mundo a fora Meu amor, não vá chorar Ao ver, que o cajueiro anda florando Saiba que estarei voltando, princesa do meu lugar.
}

Outra vez o autor se impõe como eu lírico na canção, iniciando com uma conversa com uma terceira pessoa, trazendo aqui então o desejo de sair de sua terra para um mundo exterior e estranho, mesmo estando na mesma delimitação geográfica em que se compreende o Brasil. Nesse sentido, Belchior

27 VALBUENO, Eduardo. YOUTUBE - Belchior - Princesa do meu lugar (Programa Som Brasil).12 abril. 2012. 3min. 48s. Disponível em: <https://youtu.be/FaY55w6PwRQ> Acesso em: 10 out. 2018. 
entra sutilmente com a canção que interpreta através da sua voz tipicamente nordestina nos causando um sentimento de reflexão profunda sobre as idas e regressos, casando com o texto introdutório de Lima Duarte. Usando indicativos da natureza como o "cajueiro florando", simbolizando um tempo de fartura no sertão com pequenas chuvas em tempo de estiagem, podendo voltar para a "Princesa do meu lugar", título da canção que remete a uma mulher amada, mas também nos faz pensar e a remeter quase que automaticamente no apelido carinhoso que a cidade origem do cantor, Sobral, possui como "Princesa do Norte", distinguindo-a dos demais municípios do Ceará, dando um sinônimo de realeza.

\author{
A terra toda é uma ilha \\ Se eu ligo, meu radinho de pilha \\ Terás notícias de mim entre as carnaubeiras \\ Meu amor é um passarinho \\ Pode fugir da tua mão, \\ Não dances, não dances pelo caminho \\ Ou não vou-me embora não
}

Dando continuidade aqui aos versos em que se desenvolve a canção, podemos perceber uma entonação maior no canto da estrofe, trazendo questões interessantes que em ocasiões de abordagem em entrevistas, Belchior fala da importância do rádio no sertão e de como a população e ele mesmo 243 reagia a isso.

$\mathrm{O}$ rádio é um objeto realmente mágico no interior, no profundo interior. $\mathrm{O}$ interior era cheio de serviços de autofalantes. [...] e esse serviço de autofalante modulou a vida de muitas populações interioranas do Ceará, da Bahia, da Paraíba ${ }^{28}$.

Nesse sentido, podemos entender que o rádio estava, no período de composição da música, bem presente no cotidiano do sertão ainda na década de 1970, onde a notícia interligaria todas as pessoas por esse veículo de comunicação, transformando toda distância da sua terra em uma "ilha", podendo dizer "entre as carnaubeiras", planta nativa da região de Sobral, quando ele voltaria.

Já na segunda metade da estrofe, podemos observar que há um certo simbolismo poético na condição de amor como um passarinho, ou algo inconstante que deve alçar voo, e que a qualquer movimento brusco pode se lançar de onde está ou podendo significar que seu regresso depende ou não de ocasiões imprevisíveis.

28 FRANZ, João Antônio. YOUTUBE: Belchior - MPB Especial (02/10/1974). 05 nov. 2016. 51min. 42s. Disponível em:< https://youtu.be/94-rOEVnyDg > Acesso em: 14 out. 2018. 
Não há pranto que apague

Dos meus olhos o clarão

Nem metrópole onde eu não veja

O luar, o luar do sertão!

E, para finalizar a canção, Belchior traz da mesma forma que na canção Fotografia 3X4, a condição de que nem mesmo as dores, nem os encantamentos da cidade grande, podem desvanecer "dos olhos" dele o sentimento que o eu lírico da canção nutre e preserva pelo seu lugar de partida, fazendo uma citação direta da canção interpretada pelo grande Luiz Gonzaga, "Luar do Sertão" 29 , no qual retrata que nada nos centros urbanos se compara com as belezas do sertão.

\section{Considerações finais}

Belchior foi e é uma personalidade na nossa música popular brasileira envolta de mistérios ditos e não ditos e, em sua trajetória, passou por intempéries e escolhas pessoais que ao longo da vida o fez se isolar da fama e se dedicar aos seus trabalhos e metas íntimas, mas isso não fere a importância de sua extensa obra, de uma riqueza que simboliza indiscutivelmente o seu protagonismo como agente produtor cultural junto ao Pessoal do Ceará, sendo inesquecivelmente "apenas um rapaz latino-americano" e que soube, através das notas emitidas, representar toda uma geração e que a cada reprodução dos seus discos com a agulha na vitrola, todos "rejuvelhecemos" ao ouvir esse "rapaz delicado e alegre que canta e requebra".

29 Não há, ó gente, ó não/Luar como esse do sertão. Não há, ó gente, ó não/Luar como esse do sertão/Oh! que saudade do luar da minha terra/Lá na serra branquejando folhas secas pelo chão/Este luar cá da cidade tão escuro/Não tem aquela saudade do luar lá do sertão/Não há, ó gente, ó não/Luar como esse do sertão. Não há, ó gente, ó não/Luar como esse do sertão /Se a lua nasce por detrás da verde mata/ Mais parece um sol de prata prateando a solidão/E a gente pega na viola que ponteia/E a canção e a lua cheia a nos nascer do coração/Não há, ó gente, ó não/Luar como esse do sertão. Não há, ó gente, ó não/Luar como esse do sertão/Mas como é lindo ver depois por entre o mato/ Deslizar calmo, regato, transparente como um véu/No leito azul das suas águas murmurando/ E por sua vez roubando as estrelas lá do céu/Não há, ó gente, ó não/Luar como esse do sertão/Não há, ó gente, ó não/Luar como esse do sertão. 


\section{Parte 4}

\section{Política e economia nas tramas do cotidiano}





\title{
20. A Ação Integralista Brasileira (AIB) e sua influência no interior do Ceará: memórias do Integralismo em Ibiapina
}

\author{
Odail José Martins Freire ${ }^{1}$
}

\section{Introdução}

A presente discussão tenciona tratar da presença e influência do movimento politico nacionalista conhecido como integralismo na cidade de Ibiapina-CE, a partir do contexto de sua atuação dentro das cidades interioranas do estado. Para isso, pretende-se abordar acerca de como se deu a concepção desse movimento dentro do estado e como ele se insere na dinâmica da política local dentro dessas cidades e, por fim, busca retratar como o integralismo esteve presente em Ibiapina e que impactos teve na cidade, a partir de memorialistas, filhos ilustres da cidade.

Ibiapina foi elevada à categoria de município no ano de 1938, estava se firmando ainda, e a respeito dessa década de 30, o memorialista José Eliomar Damaceno ${ }^{2}$ nos fornece um panorama:

[...] Em 1938, Ibiapina já tinha algumas dezenas de ruas, duas praças (lá chamadas avenidas) - a da Matriz e a Miguel Soares - três igrejas: Matriz, São Francisco e N. Sra. do Bom Parto; uma cadeia pública, edificada em $1879,[. .$.$] um matadouro ou$ curral do açougue, um cacimbão público, um mercado público e um cemitério [...] Uma central gráfica muito importante, pois falava por telefone com Fortaleza, Sobral, Teresina e as cidades da Serra; havia também comunicação por Morse. As ruas de Ibiapina foram calçadas com pedras, que até hoje por lá existem³.

No final da década de 30 eram raras as casas que se destacavam por seu aspecto moderno e estético, e também eram raras as passagens de automóveis ou caminhões pela cidade. Porém, o progresso estava avançando cada vez

Graduando do Curso de Licenciatura em História pela Universidade Estadual Vale do Acaraú-UVA. Foi comerciário, comerciante e professor, nasceu na cidade de Massapê e aos dois anos de idade, juntamente com seus pais, muda-se para Ibiapina, onde o autor viveu sua infância.

3 DAMACENO, Jose Eliomar. A Ibiapina do meu tempo: Reminiscências de um município do Ceará.

Fortaleza: Expressão Gráfica, 2001. 
mais pelo país e chegando também às cidades interioranas, como o próprio autor diz: "Não sabíamos, nem notávamos, mas o progresso silenciosamente, vagarosamente se dirigia para aquela região e hoje por lá se estabelece".

A produção historiográfica do século XX não era feita apenas pelos historiadores, mas também pelos memorialistas, estes que possuem papel de destaque na escrita, preservação e construção da memória, inclusive a Ibiapinense e sobre a qual se baseia a construção das memórias do período integralista na cidade.

O Integralismo era também conhecido como Ação Integralista Brasileira (AIB), foi um movimento político de extrema-direita, fundado pelo jornalista Plínio Salgado no ano de 1932 e foi chefiada nacionalmente por ele, desde a sua fundação naquele ano, até a data de sua extinção pelo Estado Novo, em 1937. Salgado era um jornalista, escritor e político que possuía ideais ultraconservadores alinhados à extrema-direita e que atuou no Brasil durante a década de 1930. O marco da criação desse movimento foi quando Salgado lançou o Manifesto de Outubró.

A fundação da AIB foi precedida pela organização da Sociedade de Estudos Políticos (SEP) que, juntamente com o jornal A Razão, propiciou a criação da AIB. A finalidade da SEP era:

[...] preencher o vácuo ideológico deixado pela Revolução de 1930, diante das indefinições, segundo Salgado. Dentre seus objetivos principais estão a colaboração para a construção da unidade nacional; o reforço da autoridade; a coordenação de todas as classes produtivas para o fortalecimento da nação; apoio ao pensamento político que seja baseado nas realidades nacionais"s.

O integralismo conferia grande importância aos símbolos e às imagens, como em relação à escolha do nome, que de acordo com o historiador Roney Cytrynowicz:

As palavras que formam o nome do partido fornecem algumas pistas. "Ação" sugere mobilização, força e violência; agir e não pensar em nome da ideologia que salvaria a humanidade e implantaria um Estado forte e sem sociedade civil. "Integralista" vem de integral e remete à ideia de totalidade, que vai contra a democracia dos partidos, o sistema de representação, a diver-

O Manifesto de Outubro é a Carta Magna do Integralismo, em cujos princípios se baseia e se assenta toda sua estrutura política e social.

ALVES, Cristiano Cruz. O Integralismo e sua influência no anticomunismo baiano. Disponível em: Antíteses, vol. 1, n. 2, jul.-dez. de 2008, p. 407-438 http://www.uel.br/revistas/uel/index.php/antiteses. 
sidade e os conflitos inerentes à vida social e política. "Brasileira” se refere à defesa exacerbada do nacionalismo em oposição aos partidos estaduais, regionais e internacionalistas - como o Partido Comunista"6.

Os integralistas possuíam vestimenta própria de características militares, na cor verde-oliva, uma saudação típica: "anauê"7 e uma bandeira com o símbolo grego sigma $(\Sigma)$ representando a ideia de somatório, de um todo. Os "Camisas Verdes", como também eram conhecidos, eram opositores do liberalismo, anarquismo e comunismo. Contra estes últimos, vários conflitos de rua foram registrados na década de 1930. O movimento integralista tinha por lema "Deus, Pátria e Família"; a partir disso pode-se entender as propostas desse movimento, que também ficou conhecido como o fascismo brasileiro. A palavra "Deus" indicava a influência religiosa cristã dos integralistas, tendo a figura divina em primeiro lugar, pois para eles era Deus "quem dirigia o destino dos povos". A pátria, para os integralistas, podia ser definida como "nosso lar". Assim, propunham-se a alcançar a unidade da população brasileira dentro do território através da constituição de um Estado integral, em contraposição à divisão da sociedade em classes. Já família, dentro da proposta integralista, é a menor unidade e seria o "início e fim de tudo".

Em suma, pode-se definir esse movimento como "nacionalista, autoritário, tradicionalista e fundado em preceitos religiosos, cabendo ao Estado manter a unificação integral da sociedade através da coerção" ${ }^{8}$.

\section{A AIB no estado do Ceará e sua expansão para os municípios interioranos}

O início do movimento da AIB no Ceará coincide com a data de sua fundação em âmbito nacional, 1932, porém, a expansão da Ação Integralista Brasileira para o interior do estado, com a criação dos Núcleos Municipais, ocorreu intensamente a partir de 1934. Josênio Parente afirma que a fundação da AIB no Ceará ocorreu no dia 15 de novembro de 1932, com a instalação do núcleo provincial em Fortaleza ${ }^{9}$. Antes do início das atividades da AIB no estado cearense, João Rameres Regis nos diz que, antes mesmo de vir à cena o movimento integralista, foi fundada a Legião Cearense do Trabalho (LCT) no Ceará, no dia 23 de agosto de 1931.

6 CYTRYNOWICZ, Roney. A força e a pátria em ação. Revista de História da Biblioteca Nacional. Rio de Janeiro, edição no 6, p. 21-25, 2010.

7 Vocábulo tupi, era uma expressão utilizada como forma de dar as boas-vindas e significa "você é meu parente".

8 PINTO, Tales Dos Santos. “O que é Integralismo?"; Brasil Escola. Disponível em: <https://brasilescola. uol.com.br/o-que-e/historia/o-que-e-integralismo.htm>. Acesso em: 09 out. 2018.

9 PARENTE, Josênio Camelo. Anauê - Os Camisas Verdes no Poder. Fortaleza: EUFC, 1999, p. 181. 
A LCT, entidade fundada pelo Tenente Severino Sombra com a colaboração de outro tenente, Jeová Mota, coadjuvados pelo recém-formado padre Hélder Câmara, serviu de base para a criação da AIB no Ceará. Agremiações como a LCT garantiam a intervenção da Igreja Católica na vida social e política do Brasil, a partir das orientações do Centro Dom Vital, inspirada na encíclica Rerum Novarum do Papa Leão XIII ${ }^{10}$.

Em relação ao processo de expansão da AIB para os municípios do interior do estado, o movimento integralista alterou a dinâmica política local ao mesmo tempo em que se ajustava ao jogo político das elites locais. Essa experiência integralista, de acordo com João Rameres Regis, marcou o imaginário político da população interiorana ao se integrar e ao interagir com a cultura política prevalecente nesses municípios, que na década de 1930 eram a extensão da vida rural, com uma vida urbana muito incipiente. O autor ainda afirma que:

Os dois elementos que serviram ao sucesso integralista nos distantes municípios do Ceará foram: as críticas contundentes ao regime liberal e à dinâmica política derivada desse modelo que colocava nas mãos dos coronéis locais, um poder quase absoluto em seus potentados; e o discurso anticomunista difundido pela Igreja Católica, pelos grupos políticos conservadores e pelas agências do Estado ${ }^{11}$.

Foram esses elementos, aliados à comoção que a Revolução de 30 causou, que levaram grande parte da população do Ceará a aderir ao movimento integralista, comoção essa devido à grande aversão ao regime coronelístico, que era tão intrínseco na dinâmica política das cidades interioranas do estado.

Foi exatamente nesse contexto de crise do coronelismo clássico que os núcleos integralistas foram criados no interior do estado. Devido ao grande número de Núcleos Municipais e Distritais que foram fundados a partir do ano de 1932, o movimento da AIB encontrou grande repercussão entre as populações do interior do estado do Ceará. Ao todo constata-se que foram constituídos 54 Núcleos Municipais dentre 66 municípios existentes e 07 Núcleos Distritais.

Márcia Regina S. Ramos Carneiro atribui isso a três fatores principais:

[...] a crise do modelo clientelístico e paternalista ocorrida com a Revolução de 1930, que despertou na sociedade a condição

10 REGIS, João Rameres. Integralismo e coronelismo: interfaces da dinâmica política no interior do Ceará (1932-1937), Tese de Doutorado. Universidade Federal do Rio de Janeiro (UFRJ). 2008, p. 115-116.

11 REGIS, João Rameres, Op. cit., p. 108. 
do exercício político, a possibilidade de intervir nos assuntos da nação; a marcante presença da Igreja Católica que através da Ação Católica - AC - e da Liga Eleitoral Católica - LEC interveio muito incisivamente no debate político do período, atraindo para si os elementos nacionalistas de direita e aqueles que haviam sido desprestigiados com a Revolução de 1930; e a proposta de moralização do país através da moralização das instituições públicas, defendida pelo movimento da AIB que traduzia, de certa forma, os anseios de parte da população brasileira e também através da promessa de solução dos problemas crônicos, de forma imediata ${ }^{12}$.

É possível constatar a influência que o Integralismo teve no interior, pois ele se inseriu praticamente em todas as regiões do estado: da capital ao Cariri - extremos norte e sul do estado; do Vale do Jaguaribe - extremo leste, à Serra da Ibiapaba - extremo oeste, e toda a região do chamado Sertão Central. Em Ibiapina, quem esteve à frente representando o movimento como chefe municipal na cidade foi o prefeito da época, José Monte Aragão.

\section{Memória integralista em Ibiapina-CE}

Rameres diz que a ausência de documentação produzida nos municípios dificulta perceber a mecânica do movimento quanto à sua organização interna, porém, pode-se inferir que havia um nível de concentração das responsabilidades na chefia local, mantendo, numa escala menor, a conhecida infalibilidade reservada ao Chefe Nacional. ${ }^{13}$ Há uma lacuna na documentação trabalhada que atesta a relação orgânica dos núcleos municipais mais distantes, espalhados pelo vasto território nacional e, em especial, dos núcleos interioranos do Ceará. E Ibiapina insere-se dentro desse contexto, que seguiu a politica empregada nas outras cidades interioranas, onde é possível que o chefe, muitos deles oriundos dos grupos políticos que já detinham certo poder no município, arcasse com essa estrutura, pois de certa forma não deixava de ser um investimento político de retorno seguro.

As documentações desse período são escassas, assim como as referentes a outros momentos vividos na cidade. Damaceno, em seu livro A Ibiapina do Meu Tempo, onde busca retratar as memórias vividas por ele em Ibiapina, nos fornece um parâmetro acerca de como se deu Integralismo dentro do cotidiano da Cidade:

[...] em Ibiapina também existiu uma célula desse partido político, onde as reuniões eram constantes. A mocidade da época

12 CARNEIRO, Márcia Regina S. Ramos. Memória e Integralismo: um estudo da militância no Rio de Janeiro. Dissertação de Mestrado, Universidade Federal Fluminense - UFF, Niterói, RJ: 2002 e CARNEIRO, Márcia Regina S. Ramos. Do sigma ao sigma - entre a anta, a águia, o leão e o galo - a construção de memórias integralistas. Universidade Federal Fluminense - UFF, Niterói, RJ: 2007.

13 REGIS, João Rameres, Op. cit. 
vestia-se com aquele uniforme ao comparecer as reuniões. Eu tinha uma vontade louca de também vestir aquela roupa, sem me importar é claro com a finalidade do partido das "galinhas verdes", como lhes chamavam os adversários [...] Recordo a visita feita a Ibiapina por um historiador e escritor de renome (Gustavo Barroso) $^{14}$ (um dos líderes). Armaram um palanque nas proximidades da Matriz, de onde inflados oradores preconizavam as virtudes do Integralismo, ao mesmo tempo em que era exaltada a figura do Ilustre visitante. Este respondeu com um longo e inflamado improviso, com foguetes espocando no $\operatorname{ar}^{15}$.

Ao se observar o contexto do relato anterior, pode-se perceber que o movimento causou um certo furor na cidade, em particular entre os jovens, que mesmo alheios aos objetivos do movimento, ainda assim queriam fazer parte daquele acontecimento na cidade. Entre aqueles à frente do movimento, a presença de um dos líderes e fundadores do AIB na cidade, foi um caso de extrema importância, onde buscavam frente à figura de um dos líderes, exaltar o movimento e as ações dentro da cidade.

O movimento integralista em Ibiapina foi bastante expressivo, porém não teve uma repercussão duradoura. Francivaldo Romão, professor e memorialista, filho ilustre de Ibiapina, diz que o período Integralista teve sua expressão na cidade, mas não durou muito, o fervor deu-se somente no período em que o chefe local, José do Monte Aragão, estava à frente do movimento na cidade. Ele afirma: "[...] o integralismo na época teve expressão, mas durou pouco. O próprio coronel Pedro Ferreira não falou do integralismo na nossa história, (Ibiapina) poucas pessoas falam sobre isso" ${ }^{16}$.

Ele ainda afirma que mesmo apesar da significância que este movimento (o integralismo) teve no nosso estado, em Ibiapina o seu furor não foi muito longe. Apesar disso, o movimento surgiu, firmou-se e deixou reminiscências na nossa cidade.

\section{Considerações finais}

O período do integralismo em Ibiapina- CE foi um movimento expressivo, mas de pouca duração. As ações desenvolvidas por José Monte Aragão

14 Advogado, professor, político, contista, folclorista, cronista, ensaísta e romancista, nasceu em Fortaleza, CE, em 29 de dezembro de 1888, e faleceu no Rio de Janeiro, RJ, em 3 de dezembro de 1959. Juntamente com Plinio Salgado e Miguel Reale, liderou o movimento Integralista no País. Gustavo Barroso se destacou por encabeçar uma corrente antissemita radical, por vezes, entrando em conflito com as outras lideranças do movimento.

15 DAMACENO, Jose Eliomar. A IBIAPINA DO MEU TEMPO: Reminiscências de um município do Ceará. Fortaleza. Expressão Gráfica, 2001.

16 Francivaldo Romão, Ibiapinense, graduado em Geografia pela Universidade estadual Vale do Acaraú - UVA. Entrevistas realizadas pelo autor em 28/09/2018 e 15/102018. 
estão resumidas a resquícios de memórias de alguns cidadãos e memorialistas da cidade, e até mesmo relacionadas à sua gestão como prefeito da cidade. Francivaldo Romão diz que na Câmara, os dados disponíveis são a partir do ano de 1945, pois de acordo com ele, na redemocratização não tem nada, "a gente passou 15 anos sem eleições, na ditadura do Vargas não tinha eleições...", em vista disso, torna-se um desafio encontrar feitos e dados relativos ao período de gestão de José Monte Aragão.

A instalação de um núcleo na cidade, assim como nas outras cidades interioranas, fez parte do movimento de difusão da AIB pelo estado do Ceará. Arquivos e fontes sobre a história de Ibiapina são escassos ou muito reclusos, porém, esse período retratado mesmo que breve e de pouca expressão, é um marco da memória local e por isso se faz de extrema importância resgatar essas memórias da princesa serrana, como carinhosamente dona Rita Ximenes de Alcântara ${ }^{17}$ chama a cidade de Ibiapina.

Em vista disso, faz-se evidente a importância que os memorialistas têm na construção da história da cidade. Como cita Ana Paula Oliveira ${ }^{18} \mathrm{em} \mathrm{seu}$ trabalho de conclusão de curso ${ }^{19}$, onde diz que é perceptível a falta de importância dada pelos antigos representantes da cidade aos arquivos de Ibiapina, fato este que fez contar com a memória dos mais velhos.

Através da memória, tenta-se construir o passado da nossa cidade, uma Ibiapina ainda não conhecida pela juventude Ibiapinense. Assim, por meio desses memorialistas, busca-se "trazer esse passado aos olhos da sociedade Ibiapinense, utilizando-se das memórias como fontes." ${ }^{20}$.

\section{Fonte Oral}

Francivaldo Romão, Ibiapinense, graduado em Geografia pela Universidade estadual Vale do Acaraú - UVA. Entrevistas concedidas em 28/09/2018 e em $15 / 10 / 2018$.

Memorialista, Ibiapinense e autora de diversas obras sobre o cotidiano Ibiapinense.

18 Graduada em História pela Universidade Estadual Vale do Acaraú-UVA.

19 Ibiapina nas entrelinhas do discurso de Pedro Ferreira de Assis: "O Jequitibá da Ibiapaba." Sobral CE, 2017, p. 36

20 CARVAlHO, Ana Paula Oliveira de, Op. cit., p. 36. 



\title{
21. A economia e seus impactos: Uma análise sobre Camocim (1930-1950)
}

\author{
Valério Samaronni Morais de Queiroz1.
}

\section{Introdução}

A cidade de Camocim, situada na região norte do Ceará, é marcada por suas belezas naturais e artificiais que a cada dia passa a se exaltar pelas prenúncias de seu passado. Marcada pelo tempo onde, com o fim do porto e da estação ferroviária, teve seu declínio na economia. Tudo passa, mas as memórias ficam e dão a dimensão de que houve muitos lugares onde hoje há descaso.

Uma viagem ao passado próspero de uma cidade litorânea que teve suas principais bases econômicas removidas, porém, percebendo o lado bom das coisas, pois nem sempre temos um ponto final nos fins, mas novos recomeços. Entender o que aconteceu pode explicar o que somos hoje e desencadear um novo entendimento sobre a realidade, novos caminhos que podemos utilizar para tirar uma base sobre o passado para seguir, pois para voltar a prosperar basta começar a caminhar.

Quem não conhece sua casa pode se perder dentro de seu quarto, muitos buscam compreender a história que existe nos livros e se prendem em uma linha eurocêntrica, acabam perdendo a beleza de sua própria história. $\mathrm{O}$ fim do porto e da estação ferroviária não finda a história da cidade, porém, faz necessária a busca por novos meios de arrecadar renda para a população. Melhor conhecer e entender o que somos atualmente, como chegamos economicamente até aqui. Camocim pode ser lembrada por ser a cidade do "já teve", porém faz-se necessário montar um quadro temporal econômico da cidade. Para isso, toma-se como fonte para um debate historiográfico e melhor compreensão desse problema a obra Entre o porto e a Estação, do historiador Carlos Augusto Pereira dos Santos, da cidade de Camocim.

Todo pesquisador tem uma fonte inspiradora e referencial, seguiremos aqui a trilha proposta pelo historiador Marc Bloch em "Apologia à História ou o Oficio do historiador" (BLOCH, 2003). Ele, com seu novo modo de pensar sobre a história, nos emite nesse ar inovador grandes pensamentos 


\title{
Nossa Gente,
}

que nos levam a uma nova corrente metodológica e a novos pensamentos do real oficio do historiador. "Diz-se algumas vezes: 'A história é a ciência do passado.' É [no meu modo de ver] falar errado." Nesta frase, percebe-se como ele valorizava muito seu modo de pensar e como desenvolveu a compreensão do real ato historiador. A história de Camocim nos fala até hoje, grita em cada monumento histórico os resíduos de uma economia grande, porém sem investimento e frágil diante das mudanças nacionais.

Na obra "Entre o Porto e a Estação: Cotidiano e Cultura dos Trabalhadores Urbanos de Camocim-Ce. 1920-1970”, o Prof. Dr. Carlos Augusto Pereira dos Santos, usando a experiência das pessoas que vivenciaram a realidade do porto, nos transporta em uma leitura clara e agradável para uma realidade fascinante onde torna-se fácil compreender os motivos que fizeram Camocim ter sido tão importante para o desenvolvimento do estado. A realidade dos trabalhadores nos mostra como a economia circulava apenas com o porto e estação, a pesca também tinha grande importância, mas como na época tanto a matéria prima como a mão de obra eram baratas, não tinha grande destaque. $\mathrm{O}$ autor ainda destaca que entre esse eixo porto-estação circulava muito mais que a economia da cidadela, mas também pessoas e culturas, graças à permissão que homens de todos os lugares tinham para aportar em nossas terras. Havia grande efervescência no entra e sai que estes transportes promoveram no período analisado.

\begin{abstract}
Recuperemos um pouco da trajetória do Porto de Camocim na historiografia como este espaço de afirmação do mundo do trabalho na região. Se nos detivermos nos relatos produzidos, começaremos a perceber que a região, desde o século XVII, já vinha sendo objeto de incursões de franceses e, mais tarde, holandeses, que disputavam com os portugueses, em intervalos curtos, a simpatia dos índios e as riquezas da região. Nas expedições exploratórias desses aventureiros, é comum a citação dessas potencialidades, já prenunciando uma pretensão de conquista, consubstanciada na intenção e até na efetiva construção de fortificações na costa da região, especialmente, franceses e holandeses, usando para isso o argumento da viabilidade dessas empreitadas ${ }^{2}$.
\end{abstract}

A presente obra faz-se conhecer mais da temática, mesmo havendo necessidade de mais detalhes sobre os fatos que ocasionaram as mudanças econômicas em Camocim-CE.

Um relato breve, uma célebre obra, ou uma instigante historiografia sobre as glórias da cidade, nos desperta a pensar que já vivemos as "glórias do

2 In: SANTOS, Carlos Augusto Pereira dos. Entre o Porto e a Estação: cotidiano e cultura dos trabalhadores urbanos de Camocim-CE. 1920-1970. UFPE/CFCH. Recife, 2008. Tese de Doutorado, p. 89. 
passado" e que muitos dos jovens não conhecem, e muito menos entendem, o motivo de sermos o que somos.

\section{Um breve traçado sobre a economia de Camocim}

Jacques Le Goff, historiador das mentalidades e renomado medievalista francês, traz ideias sobre os conceitos de memória e história de grande valia. Em seu livro "História e Memória", me leva a ter uma nova maneira de compreender minha maior fonte, o povo. O homem é fruto de seu tempo e, dessa maneira, só se pode entender o que aconteceu no passado com as pessoas que vivenciaram e sentiram na pele a realidade do auge e a queda da economia de Camocim. Le Goff define: "A distinção entre passado e presente é um elemento essencial da concepção do tempo. É, pois, uma operação fundamental da consciência e da ciência históricas." ${ }^{3}$

Os interesses externos foram os responsáveis pelo fim do porto e estação. Os únicos seres que podem falar do passado com um pouco de verdade são aqueles que presenciaram os fatos e levam em suas lembranças o tesouro para os novos tempos, nada tão sublime como descobrir sua origem através de bons diálogos e se deparar com coisas que não existem mais. Apenas imaginar e não poder sentir o que aconteceu, o cérebro produz tantas substâncias quando pensamos, forte em algo, o passado sempre nos traz grandes inquietações e algumas delas não podem ser resolvidas.

Ainda sobre o livro de Le Goff, relacioná-lo à análise de Pierre Nora em Entre Memória e História, sobre as nuances do "estudar a história da História”, tornam-se valorosas também a fim de que, com elas, é possível refletir sobre uma relação ainda mais profunda destes espaços físicos e temporais com os sujeitos que os construíram.

A cidade de Camocim passou por vários ciclos na economia, mas o que mais trouxe crescimento foi o porto e estação ferroviária, esse período trouxe muito mais que crescimento econômico, como também visibilidade. $\mathrm{E}$ esse momento de ascensão do porto trouxe pessoas de todos os lugares, isso influenciou para as indústrias que aqui aportaram.

No Brasil, a ferrovia proporcionou transformações na economia, no cotidiano de muitos que viram nesse novo lugar uma oportunidade de conseguir renda, e vale ressaltar que a cidade girava em torno desse lugar por ser de onde vinham as mercadorias e compradores. Foi um alívio para o tesouro nacional, tendo em vista a entrega para a iniciativa privada, como mostra Mary Del Priore: 
O início do século XX assistiu à sua expansão. Em 1907, o presidente Campos Sales se declarou a favor do que hoje chamamos de privatização. Em pronunciamento, alegou que não havia vantagens em manter ferrovias sob a administração pública. Para alívio do Tesouro Nacional, melhor entrega-las à iniciativa privada ${ }^{4}$.

A empresa responsável pela linha que ligava Camocim às outras cidades era a RFFSA, o comércio era feito pela linha férrea dessa empresa e, nesse período, houve um auge na economia, quando eram transportados vários produtos vindos através do porto de outros países e sendo distribuídos pelo porto de Camocim, esse ciclo foi bem lucrativo pelo fato de Camocim ser o centro comercial, tanto é que um dos produtos que muito passaram por aqui destaca-se o algodão.

Quase um ano após à Revolução de 1930, o chamado Governo Revolucionário de Vargas procurou disciplinar os serviços de exportação de produtos agrícolas, que passaram a ser melhor inspecionadas e classificadas. Neste sentido, um decreto editado em agosto de 1931 reformulava a exportação do algodão, um dos produtos mais importante da pauta econômica da época 5 .

Esse momento de privatização trouxe real crescimento para a cidade, a empresa responsável por arrendar a linha férrea de Camocim foi a South American Railway:

O ramal de Camocim originalmente foi o trecho inicial da $\mathrm{E}$. F. do Sobral (Camocim-Sobral), aberto nos anos 1881 e 1882. Em 1909, toda a E. F. de Sobral foi juntada com a E. F. de Baturité para se criar a Rede de Viação Cearense, imediatamente arrendada à South American Railway ${ }^{6}$.

A ferrovia ajudou no transporte de algodão, que era produto de grande exportação, o comércio crescia cada vez mais nessa área e aí temos um tempo áureo na cidade, que durou somente no período no qual a estação funcionava. O porto já não funcionava na mesma intensidade de antes, as dunas da ilha do amor estavam aterrando o rio e dificultando a entrada de grandes navios.

4 DEL PRIORE, Mary. Histórias da gente brasileira. Memórias (1889-1950). Vol.3. Rio de Janeiro: LeYa, 2017, p. 232.

5 http://camocimpotedehistorias.blogspot.com/2017/09/vi-i-setembro-camocimvi-exportacao-de. html. Acesso em: 15 out. 2018 às $18 \mathrm{~h} 22$.

6 http://www.estacoesferroviarias.com.br/ce_sobral/camocim.htm. Acesso em: 15 out. 2018 às $18 \mathrm{~h} 25$. 


\section{Considerações finais}

Em 24 de Agosto de 1977, o trem faz sua última viagem de saída da cidade de Camocim, assim finda o ramal e as lembranças ficam vivas no povo que estava lá para se despedir. 17 anos atrás foi feito um movimento que ainda conseguiu segurar o ramal, porém, dessa vez não deu certo e a população apenas se uniu para dar seu último adeus. A partir desse momento, a cidade começa a declinar na economia, o que um dia foi o centro comercial do estado, agora acaba perdendo a vez. Assim se resguarda apenas com a história e memória de tempos áureos.

A ferrovia foi de grande importância para economia camocinense, colocando a cidade dentre as mais importantes do estado, esse período de glória trouxe um termo a cidade como terra do "já teve", já não há mais porto ou estação, somente boas lembranças desse período. O que mostra começar certo crescimento na cidade é o turismo, que após muito tempo tem ressurgido com investimentos privados nas praias que são tão belas, talvez esse seja o prenúncio para um novo período de glória. 



\title{
22. Emissoras de rádio de Camocim: o relacionamento com grupos políticos, cultura e comércio locais (1980-1989)
}

\author{
Maely Alves de Mesquita ${ }^{1}$
}

\author{
Meu caro locutor, \\ Mande esse recado para mim \\ $E$ diga ao doutor vereador \\ Que meu voto não é capim. \\ De seu curral não sou eleitor \\ Que mude, por favor \\ E faça o melhor pra Camocim! \\ M. Mesquita.
}

\section{Introdução}

Discute-se no presente trabalho a função das emissoras de rádio como meio de representação político-ideológica na cidade de Camocim-CE, ressaltando assim o caráter político do rádio. Portanto, busca-se compreender a relação estabelecida entre as emissoras e os grupos políticos locais e a dinâmica do poder político em Camocim, bem como a disputa pela audiência das emissoras radiofônicas utilizando-se da cultura e do comércio para ganhar os eleitores ouvintes.

Como sabemos, a mídia radiofônica foi e ainda é utilizada como meio de comunicação que liga o representante político local à população (eleitor). Os microfones das emissoras viraram palanques eleitorais para grupos políticos em todo Brasil. Na cidade de Camocim, localizada no interior do Ceará, ao norte do estado, não foi diferente, pois os grupos políticos rivais da cidade - conhecidos pela população como "Fundo Mole" e "Cara Preta"2 - disputaram não somente votos, aplausos e a fidelidade dos eleitores, mas também a

Graduanda do Curso de Licenciatura em História da Universidade Estadual Vale do Acaraú-UVA.

Há várias versões sobre os termos criados pela população na época. Alguns diziam que se davam pela aparência física dos dois representantes das famílias rivais, Murilo Aguiar, que tinha pintas escuras na pele, ficou conhecido como Cara Preta, e Alfredo Coelho, por usar roupas largas e folgadas, ficou descrito como Fundo Mole. O termo é usado ainda hoje, mesmo que o quadro político local e os grupos tenham se modificado. Informação retirada do Blog Camocim pote de História, do professor Carlos Augusto. Disponível em: <http://camocimpotedehistorias.blogspot.com/2011/08/os-caras-pretas-efundos-moles-de.html > Acesso em: 12 out. 2018. 
audiência dos ouvintes, que garantiam a esses grupos sua lealdade partidária e a cadeira cativa de suas programações.

Assim, no presente trabalho pretende-se apresentar a utilização da mídia radiofônica, a saber as emissoras de rádio Pinto Martins e Radio União de Camocim, como ferramenta na divulgação e na representação político-ideológica da cidade de Camocim-CE, tomando como ponto de partida no nosso recorte temporal a inauguração das primeiras emissoras de rádio AM, a Radio Pinto Martins e a Rádio União de Camocim e os nove primeiros anos das emissoras.

Primeiramente é preciso conhecer a história e a importância dessas emissoras dentro da sociedade camocinense, como funcionavam e entender seu papel político, cultural e econômico. Conhecer um pouco como se davam as relações entre os ouvintes e as programações, pois assim será possível compreender a importância política dessas emissoras para a população e para os grupos políticos dominantes. Pode-se conhecer, então, a estrutura política que por muito tempo esteve presente em Camocim e levantar questões a partir da relevância desses dois grupos políticos, que eram regidos por famílias importantes da sociedade camocinense, que desenhou e marcou a história política da cidade até os dias presentes.

Para que a história do rádio em Camocim possa ser compreendida, é preciso recorrer à história oral, pois há uma escassez de fontes quando se pretende trabalhar historicamente esse tema. Como a historiografia do rádio também é feita pelas memórias e narrativas daqueles que vivenciaram o surgimento e o desenvolvimento dessas emissoras, são utilizados aqui alguns depoimentos de ouvintes da época e de pessoas que trabalharam nas emissoras.

Conhecer a história política local nas ondas do rádio é mergulhar na memória local e conhecer uma cidade que viveu uma forte influência do rádio, não só no campo político, mas no campo cultural e econômico. As narrativas são práticas sociais e expressões da experiência vivida que, por meio da oralidade, pode-se compreender e interpretar a realidade da época aqui proposta. Assim, as narrativas aqui trabalhadas e os fatos apresentados constroem um grande quadro de relações em que estão inseridas as emissoras de rádio de Camocim. Memória, segundo Michel Pollack, está ligada diretamente à identidade, assim como as narrativas dos grupos políticos da cidade estão ligadas à identificação política, além do partidarismo inerente.

Nessa construção de identidade [...] há a unidade física, ou seja, o sentimento de ter Fronteiras físicas, no caso do corpo da pessoa, ou fronteiras de pertencimento ao grupo, no caso de um coletivo; há a continuidade dentro do tempo, no sentido físico da palavra, mas também no sentido moral e psicológico; 
finalmente, há o sentimento de coerência, ou seja, de que os diferentes elementos que formam um indivíduo são efetivamente unificados ${ }^{3}$.

O sentimento de pertencimento está em harmonia não apenas com a emoção do indivíduo, assim, para o eleitor que se sente pertencente a um grupo, está ainda mais voltado para a coerência com seu pensamento. Suas escolhas políticas, culturais, delimitam sua memória, seu grupo e ações. Restaurar ou desbravar a memória de uma comunidade é desenhar as fronteiras culturais e conhecer a partir de um ou mais indivíduos a diferenças e aquilo que os unifica.

\section{As emissoras de rádio em Camocim: das amplificadoras às ondas AM e a questão política}

Segundo Schafer, o rádio tornou-se assim o relógio da civilização ocidental, dando nova sonoridade ao cotidiano antes comandado apenas pelo sino das igrejas e apitos das fábricas ${ }^{4}$. Como reforça Caparalli, em Comunicação de massa sem massa ${ }^{5}$, o rádio tornou-se também um meio de grande eficácia na estratégia política, pois atinge níveis expressivos de popularização e o poder dessa persuasão exercida por estar inserido na vida cotidiana das pessoas. A utilização e a instrumentalização das emissoras de rádio durante a década de 1980 e 1990, sejam elas locais ou mundiais, nada mais é que fruto de uma utilização histórica do rádio como instrumento de reprodução ideológica desde o surgimento dessa tecnologia como meio de comunicação de massa. Os grupos políticos de Camocim utilizaram do alcance e da popularização desse meio de comunicação para manterem seus domínios ideológicos sobre a população.

Aos poucos, com o aprimoramento dos sistemas radiofônicos, as cidades do interior do Brasil passam a ter suas rotinas mudadas com a chegada dos aparelhos e das programações. Antes de existir o rádio no sistema AM (Amplitude Modulada), existiam as amplificadoras, que se utilizavam do serviço de alto-falantes. Em Camocim, cidade do interior do Ceará, localizada no litoral oeste do estado, a $347 \mathrm{~km}$ de Fortaleza, conhecida por belas praias e pela sua importância econômica e cultural, teve seu cotidiano e produção cultural marcado pelo som do apito do trem e dos navios que ancoravam

POLLACK, Michael. Memória, esquecimento, silêncio. Estudos Históricos. Rio de Janeiro, v. 2, n. 3, 1989, p. 3-15.

4 SCHAFER, R. Murray. Rádio radical. Rádio Nova: constelações da radiofonia contemporânea, v. 2, 1997.p. 29.

5 CAPARELLI, Sérgio. Comunicação de massa sem massa. Summus Editorial, 1986. 
em seu porto, mas também influenciado fortemente pelas ondas sonoras das amplificadoras durante a década de $1940^{6}$.

A Amplificadora Pinto Martins foi a pioneira neste sistema na região, inaugurada em 20 de setembro de 1941, tendo como proprietário o Sr. Francisco das Chagas Vasconcelos. A amplificadora possuía dois alto-falantes situados na praça Pinto Martins, bem ao lado do Mercado Municipal de Camocim. Em pouco tempo, outras amplificadoras surgiram na cidade, como a amplificadora Camocim Clube e a amplificadora $A$ Voz de Camocim ${ }^{7}$. Durante este período, a Amplificadora Pinto Martins serviu na divulgação de músicas, de eventos de lazer, publicidade de todo tipo e, principalmente, na utilização das ondas sonoras para apologia partidária. Nas eleições, os partidos locais recorriam ao alcance da Amplificadora Pinto Martins para fazerem seus comícios e reuniões e utilizavam os microfones para divulgarem seus trabalhos na calçada e na praça, com o apoio da amplificadora, seja qual fosse o candidato, desde que pagasse a quantia correspondente ao horário de utilização.

Foi em um desses comícios veiculados pela Amplificadora Pinto Martins que se deu o motivo da divisão política entre duas famílias influentes de Camocim, que já faziam parte da história política local: a família Coelho e a família Aguiar. De um lado representada pelo comerciante e político Alfredo Othon Coelho, família Coelho e seus aliados identificados pelos opositores 264 como Fundo Mole, e a família Aguiar, representado na figura de Murilo Rocha Aguiar (também comerciante e político), juntamente com seus aliados, que passaram a ser chamados pelos adversários de Cara Pretas. Em 1950, durante a campanha eleitoral para prefeito, aconteceu o rompimento político entre essas duas famílias importantes em Camocim, que marcaria fortemente o jeito de se viver a política na cidade. O Sr. Orion Menezes, em entrevista ao historiador Carlos Manuel do Nascimento, em seu trabalho sobre as amplificadoras em Camocim, relata em sua fala como se deu o rompimento entre as duas famílias e, na sequência, como se desenrolou a campanha eleitoral daquele ano. Eis o relato:

A disputa política foi o seguinte, isso eu sei contar bem direitim: o Alfredo Coelho era compadre do Murilo Aguiar, [...] eles eram muito amigos, todos dois comerciantes do alto comércio aqui de Camocim, Alfredo Othon Coelho e Murilo Rocha Aguiar, já veio do Vicente Aguiar que começou o comércio. [...] aí veio a política, o Alfredo Coelho era da UDN e o Murilo do PSD, aí eu sei que o Murilo ficou arrepiado com o compadre que era o Alfredo Coelho, aí o Alfredo lançou a candidatura de João Colares Filho pra prefeito de Camocim. [...]

\footnotetext{
NASCIMENTO, Carlos Manuel. A cidade nas ondas do rádio. Memórias e Histórias dos Serviços de Alto-Falantes de Camocim. Capítulo III. Universidade Estadual Vale do Acaraú - UVA, 2009, p. 10. Idem.p.27-40.
} 
Pois bom, aí o resultado foi que eu estava lá no comício quando o Sr. Murilo foi falar, aí eles não deixaram o Murilo Aguiar falar, eles tomaram o microfone; aí quando botaram pro João Colares Filho, o Pascoal puxou pelo canivete e cortou o fio do microfone, foi uma confusão danada e o povo estava era aí, com a língua horrível, né? Aí o resultado, o Murilo Aguiar disse: "quem for do meu lado me acompanhe até a praça", hoje a Praça da Estação; aí menino, ficou pouca gente lá no palanque do Alfredo Coelho, pouca gente; a multidãozona acompanhou o Murilo Aguiar. Começou a partida política dele desde esse tempo. Aí o Murilo Aguiar disse: "vou lançar um candidato, o Vaqueiro da Esperança, Setembrino Veras". Ele estava lá nas Amarelas, no terreno dele lá, ele vivia mais no interior. [...] O Murilo Aguiar lançou a candidatura dele, quando foi no outro dia o Setembrino entrou aqui no carro, foi foguete, às sete horas da noite. Vaqueiro da Esperança, botaram o apelido dele, aí o Setembrino ganhou a prefeitura, aí meteu o pau no outro candidato, ajeitou a cidade, aí começou a intriga do Alfredo Coelho com o Murilo Aguiar. Foi o rompimento ${ }^{8}$.

Com o desentendimento entre as duas famílias, o cenário político da cidade tomava novas nuances, nascia a partir dali uma rivalidade política que se perpetuaria por anos, alternando o poder executivo da cidade entre os dois grupos. Os que simpatizavam com os Fundo Moles passaram a defender com unhas e dentes seus posicionamentos, os eleitores rivalizavam entre si, seguidores dos Cara Pretas não falavam com os Fundo Moles. A separação política citada acima proporcionou o surgimento da Amplificadora a Voz de Camocim, por volta do ano de 1950. O líder político Murilo Aguiar trouxe à cidade o mais moderno e organizado serviço de alto-falantes. Para competir, o líder político rival, Alfredo Coelho inaugurou, no dia $1^{\circ}$ de janeiro de 1958, o Sonoro Pinto Martins, que fazia concorrência não apenas nas ondas sonoras radiofônicas, mas também na disputa política.

As amplificadoras, mediante o serviço de alto-falantes, marcaram presença no cotidiano da população até o início da década de 1980, anunciando programações culturais na cidade e músicas, posteriormente, essas amplificadoras deram lugar às emissoras de rádio com frequência $\mathrm{AM}^{9}$, e as duas principais amplificadoras, Sonoro Pinto Martins e A voz de Camocim tornaram-se, respectivamente, Radio Pinto Martins e Radio União de Camocim.

Sob a direção de Alfredo Othon Coelho, a Rádio Pinto Martins, 1450 AM, foi inaugurada no dia 19 de dezembro de 1981, funcionando na praça

8 Entrevista com o Sr. Orion Menezes, funcionário público aposentado, 73 anos, realizado em 04/03/2008, em sua residência, situada à Rua José Maria Veras, nº. 30, Camocim-Ceará. In. NASCIMENTO, Carlos Manuel. A cidade nas ondas do rádio - memórias e Histórias dos Serviços de AltoFalantes de Camocim. Capítulo III. Universidade Estadual Vale do Acaraú - UVA, 2009.p. 37.

9 As faixas AM (Amplitude Modulada) são as responsáveis por modular os sinais de radiofrequência. A diferença se caracteriza basicamente pela técnica de produção e estética de programação. 
Nossa Gente,

Nossa História

o Ceará Republicano

Pinto Martins. Na placa de inauguração da emissora faz-se homenagem ao nome do filho ilustre de Camocim, o aviador Pinto Martins ${ }^{10}$.

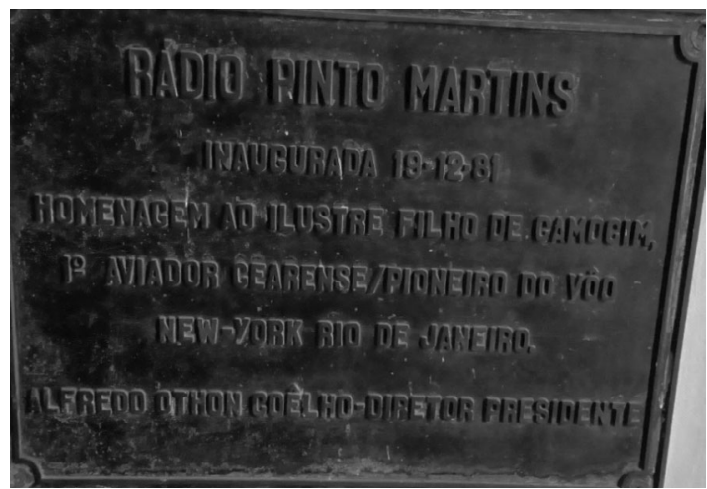

Foto 1- Placa de inauguração da Rádio Pinto Martins. Foto do arquivo pessoal da autora.

Após dois anos da comemoração do centenário da cidade, a emissora foi inaugurada durante o mandato do prefeito Edilson Veras Coelho. Abaixo a concessão para funcionamento da Rádio Pinto Martins AM, um ano antes de sua inauguração.

DECRETO No 84.968, DE 28 DE JULHO DE 1980.

Outorga concessão à RÁDIO PINTO MARTINS LTDA., para estabelecer uma estação de Radiodifusão sonora em onda média de âmbito regional, na cidade de Camocim, Estado do Ceará.

O PRESIDENTE DA REPÚBLICA, usando das atribuições que lhe confere o art.81, item III, combinado com o artigo $8^{\circ}$, item XV, letra " $a$ ", da Constituição, e tendo em vista o que consta do Processo MC no 15.306/78 (Edital no 99/78),

\section{DECRETA:}

Art. $1^{\circ}$ Fica outorgada concessão à RÁDIO PINTO MARTINS LTDA., nos termos do artigo 28 do Regulamento dos Serviços de Radiodifusão, aprovado pelo Decreto número 52.795, de 31 de outubro de 1963, para estabelecer, sem direito de exclusividade, uma estação de radiodifusão sonora em onda média de âmbito regional, na cidade de Camocim, Estado do Ceará. Parágrafo único. $\mathrm{O}$ contrato decorrente desta concessão obedecerá às cláusulas baixadas com o presente e deverá ser assinado dentro de 60 (sessenta) dias, a contar da publicação deste Decreto no Diário Oficial da União, sob pena de se tornar nulo, de pleno direito, o ato de outorga.

Art. $2^{\circ}$ Este Decreto entrará em vigor na data de sua publicação, revogadas as disposições em contrário.

${ }_{10}$ Fotografia atual da placa de inauguração da emissora Pinto Martins, a placa está fixada na parede do corredor de entrada no prédio da emissora. 
Brasília, 28 de julho de 1980; 159 da Independência e $92^{\circ}$ da República.

\section{JOÃO FIGUEIREDO}

H.C. Mattos ${ }^{11}$.

Não demorou muito para que o grupo da família Aguiar, os Cara Pretas, conseguissem também sua concessão, com a Rádio União de Camocim, 820 AM, com sede na rua Dr. João Thomé, de frente à praça Vicente Aguiar, a Praça da Estação, mesmo local que Murilo Aguiar havia levado seus seguidores após o desentendimento anos atrás. Assim, no mesmo ano de inauguração da Radio Pinto Martins, a emissora Radio União de Camocim conseguia sua concessão para entrar no ar, sendo posteriormente inaugurada no dia 14 de outubro de 1982.

\section{DECRETO No 86.168, DE 29 DE JUNHO DE 1981}

Outorga concessão à RÁDIO UNIÃO DE CAMOCIM LTDA., para estabelecer uma estação de radiodifusão sonora em onda média de âmbito regional, na cidade de Camocim, Estado do Ceará.

O PRESIDENTE DA REPÚBLICA, usando das atribuições que lhe confere o artigo 81, item III, combinado com o artigo $8^{\circ}$, item XV, letra " $a$ ", da Constituição, e tendo em vista o que consta do Processo MC no 11.477/80 (Edital n 33/80),

\section{DECRETA:}

Art. $1^{\circ}$ - Fica outorgada concessão à RÁDIO UNIÃO DE CAMOCIM LTDA., nos termos do artigo 28 do Regulamento dos Serviços de Radiodifusão, aprovado pelo Decreto no 52.795 , de 31 de outubro de 1963, para estabelecer, sem direito de exclusividade, uma estação de radiodifusão sonora em onda média de âmbito regional, na cidade de Camocim, Estado do Ceará. Parágrafo único - O contrato decorrente desta concessão obedecerá às cláusulas baixadas com o presente e deverá ser assinado dentro de 60 (sessenta) dias, a contar da publicação deste decreto no Diário Oficial da União, sob pena de se tornar nulo, de pleno direito, o ato de outorga.

Art. $2^{\circ}$ - Este decreto entrará em vigor, na data de sua publicação, revogadas as disposições em contrário.

Brasília, DF, 29 de junho de $1981 ; 160^{\circ}$ da Independência e $93^{\circ}$ da República.

JOÃO FIGUEIREDO ${ }^{12}$.

As concessões de rádio durante o período da ditadura ajudavam o regime militar na propagação ideológica, mas essas concessões eram regidas por

11 Disponível em: < http://www2.camara.leg.br/legin/fed/decret/1980-1987/decreto-84968-28-julho1980-434453-publicacaooriginal-1-pe.html >. Acesso em: 19 mar. 2018.

12 Disponível em: http://www2.camara.leg.br/legin/fed/decret/1980-1987/decreto-86168-29-junho1981-435547-publicacaooriginal-1-pe.html >Acesso em: 19 mar. 2018. 
seus ditames, onde procurava-se coibir as condutas tidas como abusivas no exercício da liberdade de radiodifusão. A censura previa penalidades para as emissoras que infringissem tais condutas.

Hoje, por lei, é proibida a utilização das emissoras para fins político-partidários, mas o que se observa é que as emissoras de rádio até hoje, em sua maioria, pertencem a grupos políticos. A história radiofônica de Camocim está vinculada com a política, como tantas outras cidades do Brasil.

No ano de 1988, período de redemocratização e o surgimento de uma nova constituição, em Camocim a configuração política é a mesma, duas famílias se revezam na prefeitura e, no ano de 1989, Murilo Rocha Aguiar, pertencente ao grupo Cara Preta, assume a prefeitura tão disputada. As emissoras pertencentes aos dois grupos ainda possuem a mesma influência junto à população, assim como seus padrinhos e representantes políticos.

\section{O papel cultural e econômico das emissoras de rádio}

O rádio teve uma importância muito grande no contexto do regime militar, vários momentos históricos foram transmitidos por esse meio de comunicação. A ditadura utilizou-se dele para veicular programas oficiais e propagandas, e a resistência contra a ditadura também passou pelas ondas radiofônicas. No início da década de 1980, o rádio ainda era parte fundamental do cotidiano da população brasileira. $\mathrm{O}$ "radinho de pilha" era um companheiro inseparável dos trabalhadores mais pobres, não só no local de trabalho, mas também no caminho de volta para casa, nas primeiras horas da manhã, ou na solidão dos dormitórios.

Eram os aparelhos de rádio que faziam a população rural ficar informada do que estava acontecendo na cidade. Os programas informavam as mudanças políticas locais, tocavam as músicas de sucesso da época, anunciavam as promoções e os produtos das lojas e divulgavam o nome dos comerciantes da cidade. Os programas de forró e as vozes dos locutores se misturavam às emoções dos ouvintes. O rádio ia além da aparelhagem política.

Nos últimos anos da ditadura, Camocim passava por mudanças no cenário político: dois grupos revezavam-se no poder executivo e, em 1982, temse a primeira mulher ocupando o cargo de prefeita da cidade: Ana Maria Beviláqua Moreira Veras, do PDS (Partido Democrático Social), aliada do grupo Fundo Mole. Nos seis anos de seu mandato, Ana Maria utilizou-se da rádio e dos radialistas para colocar em ação projetos culturais, como festivais de música e de violeiros. Nesse período, muitos repentistas se tornaram radialistas e utilizaram os microfones para divulgar seus trabalhos e a cultura popular, canções, repentes, divulgação de cantorias que aconteciam pela região e publicidade. 
Em entrevista, o cantador repentista Sr. João Batista Sobrinho conta que, junto com outros cantadores e radialistas, e com o apoio da prefeita Ana Maria, desenvolveu um evento para repentistas e violeiros que mais tarde se tornaria o Festival de Violeiros de Camocim.

[...] em junho de 82, de 1982 eu cheguei aqui em Camocim e formei dupla com o poeta Damião Libório na Rádio Pinto Martins, logo as pessoas ficaram sabendo do trabalho que eu já vinha fazendo em festivais em vários lugares, como Monsenhor Tabosa, outros lugares como Tianguá onde eu já tinha morado, eu fui cobrado pelas pessoas e comecei a organizar o festival com o Damião e o apoio da prefeitura, a gente organizou em outubro de 82 , não tô lembrando a data, mas em outubro de 82 foi realizado o primeiro festival de cantadores daqui da cidade de Camocim, no Instituto São José. Tinha aproximadamente um número de 20 cantadores $^{13}$.

O apoio político e a divulgação na rádio dos eventos culturais traziam prestígio perante a população para o político que os encabeçava. $\mathrm{O}$ mandato de Ana Maria Veras ficou conhecido como um dos que mais incentivaram a cultura local. Nesse período, a rádio era novidade para os jovens curiosos, alguns desses jovens tornavam-se operadores de áudio e as emissoras ofereciam treinamento para os interessados, que passavam a trabalhar nas rádios e a acompanhar o dia-a-dia nas emissoras. O Sr. Francisco das Chagas Carneiro Magalhães, conhecido como Chiquinho da Rádio, que trabalha até os dias de hoje na Rádio Pinto Mastins, contou um pouco sobre como se deu sua entrada nesse meio.

Eu comecei a andar pela rádio, conheci os meninos e gostei. Aí comecei a treinar e tudo, aí um mês depois eu comecei a trabalhar na rádio, no ano de 82, o Carlos Alberto era o diretor na época, era um senhor que era casado até com a filha do dono da rádio, do primeiro dono [...] eu tinha um horário, sempre eu tive, sempre de manhãzinha, de cinco às sete da manhã. Eu trabalhava em outros horários quando faltava operador eu cobria o horário deles. Eu ficava mais na parte dos evangélicos de manhãzinha. Aí tinhas outros programas: o do Seu Damião Libório, aí depois entrava o Marcelo e o Aderaldo Lima com forró [...] aí quando vinha os ouvintes do interior eles trazia coisas pro seu Damião e para mim também, alguns levava peixe, outros prometia e não levava ${ }^{14}$.

13 João Batista Sobrinho, 69 anos, violeiro e repentista. Entrevista realizada pela autora em 20 de março de 2016. Camocim-CE.

14 Francisco das Chagas Carneiro Magalhães, operador de áudio. Entrevista realizada pela autora em 01 de maio de 2017. Camocim-CE. 
A rádio serviu para propagação de vozes não somente políticas, mas das crenças e da cultura local. Os programas evangélicos e as programações de forró ganhavam espaço dentro das emissoras. Na fala de Francisco, ele diz que "os ouvintes do interior eles trazia coisas pro seu Damião e pra mim também" ${ }^{15}$,demonstrando o carinho e a relação entre ouvintes e os que trabalhavam nas emissoras.

O público ouvinte das programações não era composto apenas por eleitores, mas também clientes consumidores, fossem de boa música, fossem do comércio local. Cada uma das emissoras possuía patrocinadores. Os grandes e pequenos comerciantes pediam aos locutores que anunciassem as promoções e seus produtos, muitos radialistas precisavam pedir patrocínio quando davam início a um novo programa na emissora. Alguns gravavam os anúncios dos patrocinadores em fita K7 para repassarem na hora do programa, outros sempre mantinham anotadas as informações sobre as lojas e os produtos. Segundo Francisco das Chagas, havia comerciantes que só anunciavam na emissora que tivesse maior audiência.

[...] tinha uns que botava nas duas, tinha uns que divulgavam só numa, dependendo da audiência da emissora os comerciantes investia. A nossa audiência era boa, até porque antigamente só tinha as duas, só tinha a Rádio Pinto Martins e a União ${ }^{16}$.

As emissoras proporcionaram maior divulgação do comércio local, pois as rádios de Camocim alcançavam cidades vizinhas e os distritos de Camocim e de Granja. A divulgação dos eventos, festivais e a publicidade emitida pelas emissoras levavam a cultura e o comercio local até outras comunidades, despertando a curiosidade dos ouvintes para conhecerem a cidade e suas atrações.

\section{Considerações finais}

A radiodifusão em toda a história brasileira foi de grande importância para que se pudesse ter um povo informado e consciente dos acontecimentos que moldaram nossa sociedade. A história do rádio e da política camocinense estão interligadas. Há quem diga que a instrumentalização política das rádios deforma e aprisiona o ouvinte aos partidos, mas o breve trabalho aqui apresentado pretendeu mostrar que a relação do rádio com os grupos, mesmo que forte, não limitou a participação dos ouvintes no fazer do rádio, sua ferramenta para comunicação cultural e comercial.

16 Francisco das Chagas Carneiro Magalhães. Entrevista já citada. 
O rádio não era somente feito de política, mas dos próprios ouvintes, $\mathrm{o}$ que eles queriam ouvir era o que tocava no rádio. A concorrência entre as duas emissoras levou os ouvintes não somente a conhecerem seus grupos políticos, mas deu a oportunidade de se fazer política através das ligações e dos anúncios. Apesar de muitas vezes ser controlado e utilizado para finalidades políticas, o rádio sempre buscou sua independência.

As mudanças nas frequências e no cenário político afetaram diretamente as emissoras de Camocim, muitas tiveram que migrar para as ondas FM na década de 1990, os grupos políticos sofreram alterações e perderam aliados importantes. A história política e das rádios de Camocim faz refletir na história da comunicação, o que é propagado hoje pela mídia e na forte influência que os meios de comunicação têm sobre o povo. Mas o principal, a relação do povo e os meios de comunicação. O rádio é como via de mão dupla, mesmo que a direção do fluxo seja direcionada politicamente.

\section{Fontes orais}

João Batista Sobrinho, Violeiro e repentista. Entrevista Realizada no dia 20/03/16.

Francisco das Chagas Carneiro Magalhães. Operador de áudio da Rádio Pinto Martins. Entrevista realizada no dia 01/05/17.

Sites:

SITE DO SENADO FEDERAL. Disponível em:<http://www2.camara.leg. br/legin/fed/decret/1980-1987/decreto-84968-28-julho-1980434453-publicacaooriginal-1-pe.html >Acesso em: 19 mar. 2018.

Iconografia:

Foto 1- Placa de inauguração da Rádio Pinto Martins. Arquivo pessoal da autora. 



\title{
23. A história da República passa por aqui! Camocim-CE (1889-1950)
}

\author{
Carlos Augusto Pereira dos Santos ${ }^{1}$
}

\section{A transição política}

O município de Camocim foi criado pela Lei No 1849 , de 29 de setembro de 1879 , ano $58^{\circ}$ da Independência e do Império. A Villa de Camocim, portanto, criada por este ato, assinado pelo então Presidente da Província, José Júlio de Albuquerque Barros, futuro Barão de Sobral, o mesmo que, dois anos antes, batera o primeiro prego para a construção da Estrada de Ferro de Sobral em Camocim, permaneceu com os mesmos limites de quando era distrito do município de Granja. Dez anos depois, ainda no Império e três meses antes do advento da República, a então vila recebeu foros de cidade pela Lei $\mathrm{N}^{\circ} 2.162$, de 17 de agosto de 1899 . Portanto, se quiséssemos, pode-

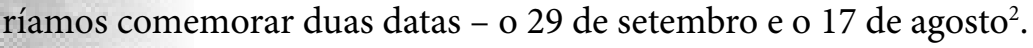

Mas o que tem este município de especial a ponto de sugerirmos que "a história passa por aqui" se, afinal, do processo histórico ninguém escapa e acontece em todos os lugares do mundo? Com uma boa dose de bairrismo (mas controlado pelos ossos do ofício dos adoradores de Clio) e ampliando o olhar para os acontecimentos mais importantes do período republicano no Brasil, nossa intenção é mostrar que em Camocim, em maior ou menor grau, estes fatos bafejados pela historiografia encontraram aqui uma correspondência digna de nota. Mesmo antes da República se instalar no país, há documentação que registra que em 02 de novembro de 1889 já existia um Club Republicano em Camocim.

Se não houve nenhuma manipulação da data de criação da agremiação republicana, os integrantes da Câmara Municipal de Camocim pareciam pressentir o ocaso imperial, além de se prepararem para continuar dando as cartas no novo regime, visto que seus nomes figurarão nos documentos posteriores no período republicano, como é o caso de Luís Gomes de Lima. Desde 1887 que seu nome aparece na documentação da Câ-

Professor do Curso de História da Universidade Estadual Vale do Acaraú-UVA. E-mail: augustus474@hotmail.com

Camocim é um município do Estado do Ceará. 
mara. Sintomaticamente, é o presidente do Club Republicano fundado em 02 de novembro de 1889, que assina como presidente da Câmara em dezembro do mesmo ano ${ }^{3}$.

Com a criação do Club Republicano, a fundação do Partido Republicano foi o próximo passo. Logo, a Câmara Municipal de Camocim providenciou o envio das mensagens de bom augúrio às autoridades que haviam tomado o poder da velha e encarquilhada monarquia. A formalização da adesão ao novo regime pode ser observada nos documentos a seguir. No ofício expedido em 26 de novembro de 1889, enviado aos vereadores, consta o seguinte, respeitando-se a grafia da época:

\section{Secretaria da Camara Municipal da Cidade de Camocim, 26 de novembro de 1889.}

Sendo de imprecendível dever a Camara Municipal manifestar ao Governo provisório federal deste Estado do Ceará a sua adhezão no heroico paço que derão na vanguarda dos mais liberais instituição pela Proclamação da República Federativa do Paiz; convoca a V.Sa., de ordem do Snr. Prezidente da Municipalidade para uma reunião extraordinária hoje às 4 horas da tarde, como digno membro da dita corporação.

Deus Guarde a V. Sa.

Ilmo. Snr. Serafim Manoel de Freitas

M. D. Vereador da Camara Municipal

O Secretario da Camara

José Carneiro de Araújo

(idêntico aos demais vereadores) ${ }^{4}$.

De imediato, analisando a documentação da Câmara Municipal de Camocim nesse período de transição da Monarquia para a República, percebemos algumas diferenças na sua formalidade. A partir de 16 de novembro de 1889, os documentos já aparecem escritos como "Cidade de Camocim" ao invés de "Villa de Camocim" e, a partir de dezembro do mesmo ano, os ofícios vêm encimados com a palavra "Cidadão", e a expressão que fechava estes ofícios, com um "Deus Guarde V. Sa", passa a ter como padrão um "Saúde e Fraternidade". O Ceará não é mais província e os documentos são enviados ao Governador do Estado. Mais do que uma formalidade, um aspecto simbólico dos novos tempos.

SANTOS, Carlos Augusto Pereira dos. A Casa do Povo. História do Legislativo Camocinense. Sobral: Sobral Gráfica e Editora, 2008, p. 55-56.

4 Arquivo da Câmara Municipal de Camocim. $1^{\circ}$ Livro de Officios Expedidos, 26/12/1885 a 11/05/1908, p. 44. 
O resultado da reunião dos vereadores de Camocim, transcrito em ata e enviado ao Governador do Estado do Ceará, não foi encontrado nos arquivos da cidade, mas seu ofício de expedição; sobreviveu aos tempos, conforme transcrevemos abaixo:

1899.

Paço da Camara Municipal da Cidade de Camocim, em sessão ordinária de 11 de dezembro de 1889.

Esta Camara tem a honra de passar às mãos de V. Ex/a , a acta da sessão de hoje por cópia, em a qual acha-se consignada uma Moção de Felicitação ao Governo Provizorio dos Estados Unidos do Brazil e aos seus muito dignos Membros do qual V. $E^{a}$. é Digno Delegado neste Estado do Ceará, cuja Moção V. $\mathrm{Ex}^{\mathrm{a}}$. se dignará fazer presente aquelle governo, com quem esta Camara se congratula.

Ilmo Snr. Tem. Cel. Luiz Antonio Ferraz

Deus Guarde V. Exª M. D. Governador do Ceará

Assignados:

Luiz Gomes de Lima

Prezidente

Leonel Dias da Fonseca Inacio Francisco Fontenelle 275 Francisco Freire Napoleão ${ }^{5}$

Este trâmite de adesão ao novo regime, com características de ter sido ordem expressa do Governo do Estado no sentido de receber imediatamente as "moções de felicitação" ao governo que se inaugurava, embora provisório, pouco mexe nas figuras de mando da política local. Naquele momento, as Câmaras Municipais são extintas para se criarem os Conselhos de Intendência Municipal. O "intendente" agora será o presidente deste conselho. Vejamos como isso se procedeu em Camocim:

Salla das Sessões do Conselho de Intendência Municipal de Camocim, em 22 de Dez., digo Janeiro de 1890.

Cidadão.

O Conselho de Intendencia Municipal desta cidade tem a honra de comunicar-vos que tendo o cidadão Prezidente da Camara Municipal recebido telegrama em que se comunicava de ordem do Governador d'este Estado, ter sido extincta a Camara Municipal e nomeado uma corporação de cinco

Arquivo da Câmara Municipal de Camocim. $1^{\circ}$ Livro de Officios Expedidos, 26/12/1885 a 11/05/1908, p. 45. 
membros para substituil-a, hoje no paço da extincta Camara, presentes três dos referidos cinco cidadãos, os signatários d'este, instalou-se a mencionada corporação com a denominação de Conselho de Intendencia Municipal, e procedendo-se a eleição para o respectivo presidente foi eleito por maioria de votos o cidadão Francisco Freire Napoleão, o que comunica-vos para os devidos fins.

Cidadão Dr. José Custódio dos Santos

Saúde e Fraternidade.

M. D. Chefe de Polícia do Estado do Ceará.

Assignados - Francisco Freire Napoleão, Severiano José de Carvalho, Quariguazil Jefferson Barreto.

Identico ao Delegado de Polícia, Juiz de Direito, Juiz Municipal da Meza de Rendas, Collector das Rendas do Estado, Suplle. Do Juiz Municipal em exercício, Promotor Público da Câmara,

Director da Estrada de Ferro e Agente do Correio ${ }^{6}$.

Com todas as autoridades cientes das mudanças que na primeira hora a República demandava, restava saber como atuariam na estrutura administrativa do Estado, afinal, teríamos agora uma federação que acenava com a participação de variados setores da sociedade. No entanto, afora os ganhos

276| que o novo regime proporcionaria, o cenário mostra que, praticamente, os mesmos homens e as mesmas forças estavam novamente no jogo político, e em Camocim não seria diferente.

Se no mundo da política os homens eram quase os mesmos, como era o munícipio de Camocim no campo religioso? Afinal de contas, se a República se inseria como um estado laico, qual o motivo de querer mapear a estrutura religiosa dos municípios? O controle sempre fez parte das preocupações dos governantes e, para temos uma vaga ideia dessa demanda, nos valemos das respostas a um questionário que as autoridades republicanas enviaram para ser respondido pelos Conselhos de Intendência de todos os municípios do Estado do Ceará.

Resposta do Conselho de Intendencia Municipal de Camocim ao Questionario que se refere a Circular No 14 de 24 de Abril do Cidadão Governador do Estado do Ceará. 1890 .

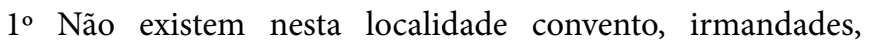
confrarias, ordens terceiras e comunidades religiosas.

$2^{\circ}$ Existe somente uma igreja, destinada a practica de actos

\footnotetext{
Arquivo da Câmara Municipal de Camocim. $1^{\circ}$ Livro de Officios Expedidos, 26/12/1885 a 11/05/1908, p. 46. Grifo nosso. Francisco Freire Napoleão é um nome que aparece na documentação ainda no tempo do Império.
} 
religiosos nesta cidade, há porém no Município duas Capellas nos lugares Gurihú e Barroquinha construídas as expensas de particulares.

$3^{\circ}$ Nada existe aqui sobre cultos acatholicos.

$4^{\circ}$ Nenhum aldeiamento de indígenas há fundado por missionários cathechistas.

$5^{\circ}$ Não há estabelecimentos, núcleos e instituições de caracter ou origem religiosa com fim humanitário de propaganda ou instrucção.

Camocim, 05 de Maio de 1890.

(Assignados)

Francisco Freire Napoleão, Prezidente.

João Evangelista Barboza

Francisco Teixeira

Severiano José de Carvalho ${ }^{7}$.

Afora estas questiúnculas paroquiais, como se dizia antigamente, como podemos aquilatar que a República não conseguiu cumprir a promessa de estender a cidadania para o conjunto da sociedade, como o direito de votar, por exemplo? Os governos anteriores se enredaram nos problemas nacionais e não conseguiram consolidar as benesses prometidas na campanha republicana. Para as eleições de 1910, duas propostas se colocaram no cenário político:

Ao lançar sua candidatura para a sucessão de Nilo Peçanha, Hermes da Fonseca, ex-ministro da Guerra de Afonso Pena, parecia o personagem ideal para restaurar as ideias de 1889 e colocar o país nos eixos caros aos militares. Mas ele não era o único pretendente ao Catete. Reagindo contra o que chamava de "militarismo iminente" e sob a bandeira da "campanha civilista”, Rui Barbosa, representante da democracia liberal, lançou-se também candidato. Foi o duelo da pena contra a espada, numa campanha jamais vista até então $0^{8}$.

Não será preciso fazer muito esforço para compreendermos as semelhanças e diferenças, dentro do contexto político vivenciado na então nascente República com a situação atual em que vivemos, onde os riscos à normalidade democrática soam como catástrofe, no momento em que mais um pleito eleitoral termina ${ }^{9}$. Mas voltemos a 1910 e vejamos como uma nota

Arquivo da Câmara Municipal de Camocim. $1^{\circ}$ Livro de Officios Expedidos, 26/12/1885 a 11/05/1908, p. $53 \mathrm{v}$.

8 DEL PRIORE, Mary. Histórias da gente brasileira. Vol. 3. República. Memórias (1889-1950). Rio de Janeiro: LeYa, 2017, p. 39-40.

9 No momento da escrita deste texto, vive-se a expectativa das eleições de 2018, a poucos dias do segundo turno, onde duas candidaturas disputam o mandato de Presidente da República, com propostas totalmente antagônicas. 
Nossa Gente,

Nossa História

o Ceará Republicano

no site do Tribunal Superior Eleitoral (TSE) contextualiza o que estava acontecendo naquele ano:

O ano de 1910 também foi marcado pela eleição para a Presidência da República. Em disputa, duas chapas com propostas claramente diversas, algo inédito no país. [...] De um lado, o militar gaúcho Hermes da Fonseca, apoiado por Nilo Peçanha, vice-presidente que havia assumido a Presidência após a morte de Afonso Pena, pelo Rio Grande do Sul e por Minas Gerais. Seu oponente foi o baiano Rui Barbosa, que angariou o apoio de São Paulo, de setores do Rio de Janeiro, da Bahia e de Pernambuco.

Hermes da Fonseca representava um projeto vinculado às ideias da oligarquia rural e da máquina estatal. Rui Barbosa, ainda que também um representante da elite do país, empreendeu uma candidatura com ares de renovação. Apresentava-se como um modernizador favorável à industrialização e à imigração. Barbosa foi, ao longo de boa parte da República Velha (1894-1930), um ícone nacional no sentido da eloquência e da cultura ${ }^{10}$.

Em 1910, portanto, vivia-se a atmosfera da sexta eleição presidencial e a quinta de forma direta. Infelizmente, não encontramos dados relacionados às eleições presidências anteriores em Camocim, mas, a daquele ano, pelo resultado final das urnas, mostra o quanto o poder continuava centralizado. Como dissemos anteriormente, mal a República havia se instalado no comando do país, as forças políticas camocinenses se alinharam ao novo sistema de governo, fundando o Partido Republicano, conforme atestam as atas da Câmara Municipal de Camocim. Em 1910, o comando do PR local ficou nas mãos do Coronel José Adonias de Araújo. Naquela época, as eleições aconteciam em $1^{\circ}$ de março e os resultados deixam evidências interessantes para compreendermos como as eleições eram realizadas. Pois bem, vamos aos resultados: O Marechal Hermes da Fonseca ${ }^{11}$ e seu vice, Wenceslau Braz, obtiveram 281 votos cada. Já o candidato oposicionista Rui Barbosa, o Águia de Haia, e seu vice, Albuquerque Lins, obtiveram apenas 1 voto cada. Afora o inusitado do resultado das eleições (ou não tão inusitado para os padrões da época, em que as eleições eram feitas à "bico de pena"), resta saber quem foi o corajoso que votou em Rui Barbosa em Camocim ou, se não houve votante nenhum, sendo apenas uma criação de quem relatou os votos em ata.

10 Disponível em: http://www.tse.jus.br/institucional/escola-judiciaria-eleitoral/revistas-da-eje/artigos/ revista-eletronica-eje-n.-5-ano-3/a-primeira-campanha-presidencial-2013-1910. Acessado em 20 set. 2015.

11 Segundo dizem os mais velhos da cidade, o Marechal Hermes da Fonseca era aparentado com os Fonsecas de Camocim e que até um de seus líderes, capitão da Guarda Nacional guardava uma espada que teria sido dada pelo velho marechal Deodoro da Fonseca. Esta é informação que merece uma confirmação posterior. 
Só para efeito de comparação, no vizinho município de Granja, nestas mesmas eleições, o Marechal Hermes e seu vice foram sufragados por 707 eleitores cada, e a chapa oposicionista recebeu 105 votos. Seria Granja mais politizada ou o voto de cabresto lá não era tão forte? Embora que em todo o país as eleições de 1910 tenham sido sangrentas como na Bahia, onde "o sistema eleitoral viciado, as forças oligárquicas divididas e as divergências entre opositores levaram ao bombardeio da cidade"12, por aqui não se verificou maiores escaramuças, com o bico de pena resolvendo ou escamoteando os conflitos.

Por outro lado, os resultados de uma eleição nem sempre medem o nível de conscientização política. Se atentarmos para a fonte jornalística, vinte anos antes deste episódio de 1910, alguns operários em Camocim mostraram como o ideário republicano calou fundo em suas consciências, denunciando o mau uso de seus nomes na constituição de um partido político no município. Como sabemos, na última década do século XX Camocim experimentava seus primeiros anos de cidade emancipada.

A transição da Monarquia para a República também era recente. Na parte política, essa transição se dava ao sabor dos interesses, como mostra a notícia do jornal "A Pátria" de agosto de 1890. Nela está contido o protesto de um grupo de cidadãos, que se diziam "operários e artistas", que reclamam de terem sido usadas suas assinaturas por outros para a constituição de um partido. Vale dizer que naquela época, «artistas» eram profissionais especializados em um ofício como carpinteiro, bombeiro, ferreiro etc.

Na pequena nota, pode-se compreender que naquele momento os operários já tinham a clarividência da importância de se mostrarem na cena política, representados por um partido político, afinal, suas assinaturas foram conseguidas para se fundar "um partido operário de socorros mutuos", confundindo-se assim, partido político com associações mutualistas e beneficentes. No entanto, uma leitura mais atenta do programa deste partido motiva a nota de protesto dos operários no jornal, que identificam o objetivo de "fazer política" com seus nomes.

Não satisfeitos com o uso de suas assinaturas, os operários Manuel Xavier Pacheco, Antônio Barachio dos Santos, Antônio Gomes de Souza, Manoel Barros Galgão e Francisco Damience Fiúza denunciam o desvio de objetivo que os senhores Aderson, Torquato Pessoa e Luís Gomes de Lima estavam fazendo com seus nomes e os desautorizando de tal expediente, ao tempo em que reafirmam pertencerem ao Club Republicano de Camocim, «filiado ao Centro de Fortaleza" ${ }^{\prime 3}$. Ao pertencerem e reafirmarem seus vínculos com o Club Republicano, os operários procuram também estar sintonizados com 
os novos ares da política prometidos pelo ideário republicano, que aos poucos se afirmava na cena política.

\section{A República nos tempos de guerra}

Como diz a historiadora Mary Del Priore, a Primeira Guerra (1914-1918) “[...] serviu pelo menos, para que se adotasse o recrutamento obrigatório. Ajudou a formação de reservas e mudou a mentalidade de que servir ao Exército era uma punição para os pobres. Doravante seria um dever cívico" $^{\prime 14}$. Em Camocim, essa mentalidade fincou raízes a ponto desta tradição militarista se achar presente até hoje no cotidiano da cidade, com as representações do Exército (Tiro de Guerra), Marinha (Capitania dos Portos) e da Polícia Militar do Ceará. Essa vocação militar, por muito tempo, alimentou uma certa "Sina Espartana", em face de um significativo número de camocinenses que alcançaram vários postos de destaque nas Forças Armadas ${ }^{15}$.

No entanto, mesmo antes da Primeira Guerra, o espírito do civismo já aportava por Camocim. Em 1912, por iniciativa do Sr. Júlio Cícero Monteiro, jornalista, intelectual e vereador local, fundou-se um Tiro Infantil ${ }^{16}$. Seria mesmo uma tradição espartana? O orgulho e ufanismo pareciam estar em consonância com os ideais republicanos:

[...] vem constituir-se mais uma nota de destaque a esta cidade, incontestavelmente uma das mais florescentes do Estado. Assim sendo é justo que todos os srs. Paes [sic] de família acolham-na de braços abertos, mandando seus filhinhos-rebentos de esperança da Pátria se aliarem as suas fileiras.

Isto, sobre ser de grande importância para os pequenos, porque já se habilitam ao manejo das armas vão se encaminhando no verdadeiro civismo, é de alta significação para a Pátria, porquanto no dia em que todo brasileiro souber desparar [sic] conscientemente uma arma de fogo qualquer, teremos integra-

DEL PRIORE, Mary, Op. cit., p. 52.

15 Cf. SANTOS, Carlos Augusto Pereira dos. Sina Espartana. In: O Literário. Ano III, Edição 16, maio de 2001, p. 5. Para fazer uma relação dos filhos camocinenses nas fileiras do Exército, temos: Generais: Onofre Muniz Gomes de Lima, Oliver Carneiro Ramos, Cleto Potiguara Veras e Júlio Veras (foi também Governador militar no Estado do Pará em 1930). Oficiais: Murilo Veras Fontenele, Tércio Veras, André Avelino Chaves, Bibiano Pessoa Chaves, os irmãos gêmeos, Haroldo Sanford Barros e Heraldo Sanford Barros, João Carvalhedo e Francisco Marques de Sousa (morto a flechadas em 1915 quando em serviço da exploração da Comissão Rondon).

16 "Ao acto de inauguração que se efectuou no Paço da Municipalidade ao meio dia, compareceram, além de muitos cavalheiros, os srs. coronel Severiano José de Carvalho, Intendente Municipal e Julio Cícero Monteiro, presidente da Câmara havendo por essa occasião um demorado exercício de marcha ao mando do distincto moço Aldezirio Neves, reservista de primeira classe do exercito, que de bom grado acceitou o convite para instructor da novel agremiação". A Palavra. "O Tiro". Camocim, 6 de janeiro de 1912, Anno VIII, nº 15, p.2. Camocim-CE. 
lisada a paz e, portanto, assegurada a estabilidade e o progresso das ubertosas plagas descobertas por $\mathrm{Cabral}^{17}$.

Como se pode apreender da matéria jornalística, a relação criança-arma nem sempre foi tão polêmica como o é atualmente, embora que os usos e abusos deste discurso sejam praticamente os mesmos, independente do tempo. O cidadão-soldado de outrora é transportado para o "cidadão do bem" armado de agora. Voltando para a citação anterior, é interessante ressaltar como o redator busca uma associação entre a agremiação militar com a ideia de "progresso", que redunda em prestígio para a cidade, relação esta muito próxima da conjuntura que justificou a mudança de regime e que era muito forte no imaginário republicano da primeira década do século XX. Neste sentido, a noção de ordem "representada pelos valores militares na sociedade" redundaria em progresso. Para consolidar essa visão, "uma revista direcionada para a divulgação da corporação militar chegou a ser editada em 1917, chamando-se 'O Fuzileiro' - revista do Tiro Brasileiro de Camocim”, cujo primeiro número saiu no $1^{\circ}$ de abril daquele ano ${ }^{18}$.

Continuemos, pois, na narrativa de como o município de Camocim vai se tornando um lugar propício para o abrigo de instalações militares:

O Exército se encontra em Camocim desde seus primórdios, primeiramente com a instalação do Tiro de Guerra No 213; posteriormente, a cidade foi cogitada para sediar um Posto de Comando pelos americanos na Segunda Guerra Mundial, sendo preterida por Fortaleza, visto que a capital proporcionava melhores condições logísticas. No entanto, uma pequena base militar foi construída como ponto de apoio para as manobras militares, abrigando um grupo de militares americanos. Utilizando mais uma vez as lembranças do nosso morador, ele afirma que a cidade "se tornou ponto estratégico importante, atraindo soldados norte-americanos e com uma base onde chegaram a atracar Zepelins", salientando um clima de colaboração entre a soldadesca e a população local, no que diz respeito às trocas gastronômicas, cuja novidade eram "as saladas de frutas em lata que os americanos distribuíam com as famílias da cidade, que por sua vez lhes presenteavam bolos"19. [...] Nos anos da ditadura militar, a cidade foi cogitada para ser sede de

Jornal A Palavra. "Actualidade”. Camocim, 6 de janeiro de 1912, Anno VIII, no 15, p. 1. Camocim-CE

18 SANTOS, Carlos Augusto Pereira dos, Op. cit., 2014, p. 11. O Tiro Infantil é de 1912, em 1913 é fundado o Tiro de Guerra 213, associado à Confederação de Tiro Brasileiro. Posteriormente foi renumerado para Tiro de Guerra 250, em 1917 ficando ligado ao Comando da 10a Região Militar, do qual é a instituição mais antiga, recebendo atualmente a numeração de 10.001. Em 2017, comemorou-se o primeiro centenário.

19 FILHO, Antônio de Albuquerque Sousa. Camocim do meu tempo. Diário do Nordeste. Ano XXV, nº 8.360, quarta-feira, $1^{\circ}$ de março de 2006, p.2. Fortaleza-CE, apud SANTOS, Carlos Augusto Pereira dos, Op. cit. 2014, p. 60. SANTOS, Carlos Augusto Pereira dos, Op. cit., 2014, p. 60. 
um batalhão do Exército, posteriormente instalado nos sertões de Crateús, aonde chegava o final da Estrada de Ferro ${ }^{20}$.

Trazendo a história para o contexto da Segunda Guerra Mundial (19391945), talvez esta mentalidade militarista forjada nas primeiras décadas do século XX, apontada anteriormente, tenha respingado nos homens de imprensa da Camocim dos anos 1940. Com efeito, a cidade foi uma das mais profícuas no interior do estado do Ceará em editar pasquins efêmeros, jornais ligados a partidos políticos, associações, clubes etc. ${ }^{21}$ Para termos uma ideia de como os jornalistas locais estavam antenados com a conjuntura beligerante de então, vejamos como isso se apresenta no jornal "O Momento", defendendo uma maior atenção para a defesa do território nacional com a construção de "uma imensa frota de bombardeiro; treinar um grande exército de guerrilhas, como a HOME GUARD dos ingleses e acabar, desde já,

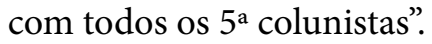

Tem sido isso, justamente o que nós do Momento de há muito vimos dizendo. Temos denunciado os quinta colunistas e os traidores por eles subornados, mostrando os propósitos de conquista do nosso país, alimentado pelos totalitários. Os fatos tem-nos dado razão. Quando o Momento publicou um artigo com a epígrafe - Camocim base naval e aérea - muita gente riu. O que nós dizíamos não passava de tolice. Agora, porém, todos estão vendo que o que dissemos naquele artigo era fruto de observação e estudo, e que a razão estava conosco ${ }^{22}$.

Retirando os possíveis exageros, o registro se justifica para pontuar, talvez, um alinhamento do jornal ao clima de guerra e da pressão ideológica encetada pelos organismos do Estado Novo comandado por Getúlio Vargas, passado sua relutância em colocar o Brasil no teatro da guerra. Talvez estejamos dando uma dimensão maior aos fatos, mas quem pode medir sua repercussão estando tão longe do local dos acontecimentos? Por outro lado, é inevitável que algo não aconteça em nosso quintal diante de uma guerra tão brutal e de escala mundial.

Para não dizer que os temores eram de todo infundados, em 1942 tem-se o registro de prisões de quatro pessoas tidas como suspeitas de algum crime, dentre eles, o alemão Werner Timm, acusado de exercer espionagem a favor do Eixo, já que fora preso em sua casa na cidade de Sobral, com material de rádio

${ }_{21}$ Cf. A cidade nas páginas dos jornais. In: SANTOS, Carlos Augusto Pereira dos, Op. cit., 2014, p. 47-51.

22 RODRIGUES, Fernando. Disciplina e Liberdade. O Momento. Ano 5, n ${ }^{\circ}$ 160. Camocim-CE, 24 de abril de 1942, p. 1. 
transmissor. Os outros três foram acusados de pertencerem a uma célula integralista e contribuírem com uma mensalidade que era entregue a um padre chamado Jonas. Ficaram apenas três dias na prisão, a mando da DOPS, provavelmente para averiguação (21.10.1942 a 24.10.1942). Já o alemão passou um período maior trancafiado, de 01.05.1942 a 19.05.1942. Essas prisões não geraram prontuários, apenas constam de uma relação da referida delegacia no Ceará, encontrada por nós no Arquivo Nacional. Essas prisões, se não se fundamentam no temor dos jornalistas de "O Momento", muito provavelmente foram frutos da onda de denuncismo contra estrangeiros, notadamente alemães, que assolou o país ${ }^{23}$.

Camocim, por sua posição geográfica, não estava longe do cenário da guerra e era favorecida pelas duas portas de entrada de homens e ideias - o porto e a ferrovia. Os acontecimentos nacionais, portanto, eram acompanhados de perto e a repercussão era sentida na sociedade local que, de algum modo, vivia e se apropriava de seus desdobramentos. Após o período da guerra, sintomaticamente vê-se em Camocim uma proliferação de instituições, como partidos, sindicatos, associações dos mais diversos objetivos, residindo aí uma singularidade que marcou a vida cotidiana na cidade e que envolveu os mais diversos setores sociais.

Mas a guerra também teria seus heróis quase anônimos: Zé da Guerra e Gerardo Fontenele Lima. O primeiro, nem tanto, posto que seu próprio nome de "guerra", conhecido de toda a cidade, já dizia muito sobre ele. O sr. Fulano de tal foi pracinha, condecorado etc. O segundo, não fosse uma Ação Declaratória movida por sua irmã, Angelita Ferreira Fontenele, não saberíamos que ele foi um dos muitos cearenses que partiram para os seringais da Amazônia, atendendo ao chamado do governo feito pelo Serviço Especial de Mobilização de Trabalhadores para a Amazônia (SEMTA). Aliás, o porto de Camocim, durante algum tempo neste período, foi ponto de partida destes trabalhadores para o esforço de guerra, que tinha como slogan "Borracha para a Vitória”. Não se sabe o fim que levou Gerardo Fontenele Lima, a não ser o que sua irmã declarou em juízo:

Gerardo Fontenele Lima, atualmente em lugar incerto e não sabido, vez que em junho de 1942 saiu de casa, deixando seus pais e irmãos por ter sido convocado pela 'SEMTA', instituição que naquela época recrutava jovens para trabalhar nos seringais da Amazonas que também eram conhecidos como Soldados da Borracha na época da Segunda Guerra Mundial e nunca deu notícia de vida ou morte, sendo totalmente ignorado seu paradeiro, dada a inexistência de qualquer notícia ou

23 SANTOS, Carlos Augusto Pereira dos, Op. cit., 2014, p. 62. 
simples informação a seu respeito, por este longo período de tempo ${ }^{24}$.

\section{Enumerando fatos, relacionando aproximações}

Com certeza, poderíamos nos estender bastante na análise de fatos do período republicano que tiveram correspondência e repercussão em Camocim. Contudo, face aos limites deste texto e da obra, faremos isso posteriormente. Por enquanto, um mapeamento rápido do que pode se constituir como objeto de pesquisas futuras.

\section{Camocim na rota das expedições científicas}

Ainda no Império, a região de Granja e Camocim foi visitada pela chamada Comissão das Borboletas (oficialmente, Comissão Científica de Exploração) ${ }^{25}$. Na primeira década do século XX, com o advento da Repúbli$\mathrm{ca}$, várias expedições científicas foram realizadas no interior do Brasil, no sentido de conhecer melhor o território, o povo, a cultura. Logo entre setembro de 1905 e fevereiro de 1906, o sanitarista Oswaldo Cruz empreendeu uma viagem de inspeção aos portos do Brasil (24, ao todo) para mapear suas condições de higiene e saneamento, visando combater o cólera e a peste. Foram 68 dias de viagem. Em cada porto, a comissão de estudos fazia um relatório e Oswaldo Cruz geralmente escrevia uma carta à sua esposa sobre o lugar em que estava, falando de fatos e pessoas com quem esteve. Camocim foi um dos portos visitados. Se ele escreveu uma carta de Camocim para sua esposa Emília Fonseca Cruz, ainda não sabemos, mas as cartas (16 no total) estão no acervo da Fundação Oswaldo Cruz e um dia pensamos em consultá-las. Quanto aos relatórios, ainda não foram encontrados e/ou disponibilizados ${ }^{26}$.

Sete anos depois, em 1912, noutra expedição, Camocim é visitada por cientistas da Fundação Oswaldo Cruz.

${ }_{24}$ Fórum de Camocim. Ação declaratória - № 2526. Autora: Angelita Ferreira Fontenele, fl. 2, Ano: 1986. Cx: 114.

25 Após a volta da Comissão ao Rio de Janeiro, vários relatórios e exposições foram elaborados e mostrados. Recolhemos, em um dos anexos de um relatório, um trecho que fala de uma exposição no Museu Nacional realizada em 1861, relativa à nossa rede de tucum, recolhida por um dos integrantes da referida comissão. Vejamos: "Uma rede de lavarinto é um trabalho primoroso que consumiu dois anos de tempo. O verdadeiro elemento da rede é feito de cordel de tucum pelos caboclos e pescadores do Camocim. São ainda imperfeitas malqueiras". BRAGA, Renato. História da Comissão Cientifica de Exploração. Disponível em: http://www.colecaomossoroense.org.br/pics/historia_dacomissao_cientifica_de_exploracao.pdf.

26 LIMA, Ana Luce Girão Soares de. A bordo do República: diário pessoal da expedição de Oswaldo Cruz aos portos marítimos e fluviais do Brasil. Disponível em: http://www.scielo.br/pdf/hcsm/v4n1/ v4n1a07.pdf. Acesso em: 20 out. 2018. 


\section{Mapeando o sertão}

Enquanto Adolpho Lutz e Astrogildo Machado singravam o São Francisco e seus afluentes, João Pedro de Albuquerque e José Gomes de Faria atravessavam os Estados do Ceará e Piauí, de março a julho de 1912. Esta expedição percorreu um longo trajeto, que incluía Fortaleza, Quixadá, Prudente de Morais (Muxuré), Quixeramobim, Baturité, Acarape e Redenção. Retornando a Fortaleza, seguia para Tutóia, Parnaíba, Teresina, Amarante, Floriano, Serra do Ibiapaba, São Benedito, Ibiapina, Jacará, Tianguá, Guatiguaba, Viçosa, Granja, Sobral, Serra de Meruóca, Ipu, Ipueiras, Pinheiro, descendo, por fim, pela estrada de ferro de Sobral até Camocim ${ }^{27}$.

No referido livro, além da referência a Camocim, da passagem da comissão pela cidade, ficou registrada uma imagem da Barragem Lima Brandão, na cidade de Granja, legendada como localizada no Rio Camocim, como era oficializado na época o hoje Rio Coreaú.

\section{A modernidade que vem do ar. O pioneirismo de Pinto Martins}

"As palavras mais repetidas na primeira metade do século XX foram ciência, progresso e modernidade. O desenvolvimento foi espetacular. Transportes, eletrificação e indústrias químicas transformavam a sociedade. [...] Novidades chegavam pelo ar", assinala a historiadora Mary Del Priore ${ }^{28}$. Camocim entra na história com a iniciativa do aviador Euclides Pinto Martins, nascido nesta cidade em 15 de abril de 1892, e o experiente piloto americano Walter Hinton em realizar um voo entre Nova Iorque e Rio de Janeiro em 1922, no sentido de fazer parte das comemorações do Primeiro Centenário da Independência ${ }^{29}$. O voo partiu de Nova Iorque em 17 de agosto de 1922 e foi muito atribulado, com várias panes e troca de hidroavião, passagem por Camocim e outras cidades, chegando ao Rio de Janeiro somente em 08 de fevereiro de 1923. Contudo, ficava inaugurada a rota aérea Brasil-Estados Unidos. O feito do aviador camocinense e de seus colegas americanos foi bastante divulgado pela imprensa da época.

Praticamente todos os veículos de comunicação da época deram destaque à chegada dos aviadores aventureiros que, finalmente, completavam o raid aéreo Nova Iorque-Rio de Ja-

27 Instituto Oswaldo Cruz. Casa de Oswaldo Cruz. A ciência a caminho da roça: imagens das expedições científicas do Instituto Oswaldo Cruz ao interior do Brasil entre 1911 e 1913. Rio de Janeiro: Editora FIOCRUZ, 1992, p. 56.

28 DEL PRIORE, Mary, Op. cit., p. 219.

29 Maiores detalhes sobre o voo pioneiro, ver as postagens do Blog Camocim Pote de Histórias, no endereço eletrônico: www.camocimpotedehistorias,blogspot.com.br. 
neiro. Naquele 08 de fevereiro de 1923 ainda estava aberta a Exposição Nacional que comemorara o Centenário da Independência em setembro de 1922. A profusão de imagens e textos (em prosa e versos) ofertados a Pinto Martins e Walter Hinton revelam bem a importância que ainda foi dada ao evento, com a presença do Presidente da República Artur Bernardes e outras autoridades da República. A partir de então, sucederam-se homenagens as mais diversas da elite carioca e paulista e de instituições da sociedade civil. A Aviação Naval, por exemplo, promoveu um almoço para os aviadores na Ilha das Enxadas. A Colônia Americana também os recepcionou com almoço no Palace Hotel. Neste mesmo local o Aero Club Brasileiro ofereceu um banquete onde Pinto Martins foi recebido por Santos Dumont. A Associação Comercial do Rio de Janeiro promoveu um chá dançante no Club dos Diários. O Club Portuguez, o Centro Beneficente Gago Coutinho e Sacadura Cabral e o Centro Maçônico realizaram sessões solenes. A Associação dos Empregados do Comércio de São Paulo, entregaram medalhas a Pinto Martins e Walter Hinton no campo de Indianápolis. Enfim... foram muitas as homenagens ${ }^{30}$. 
As fotos da época mostram a grandiosidade e o significado do evento:

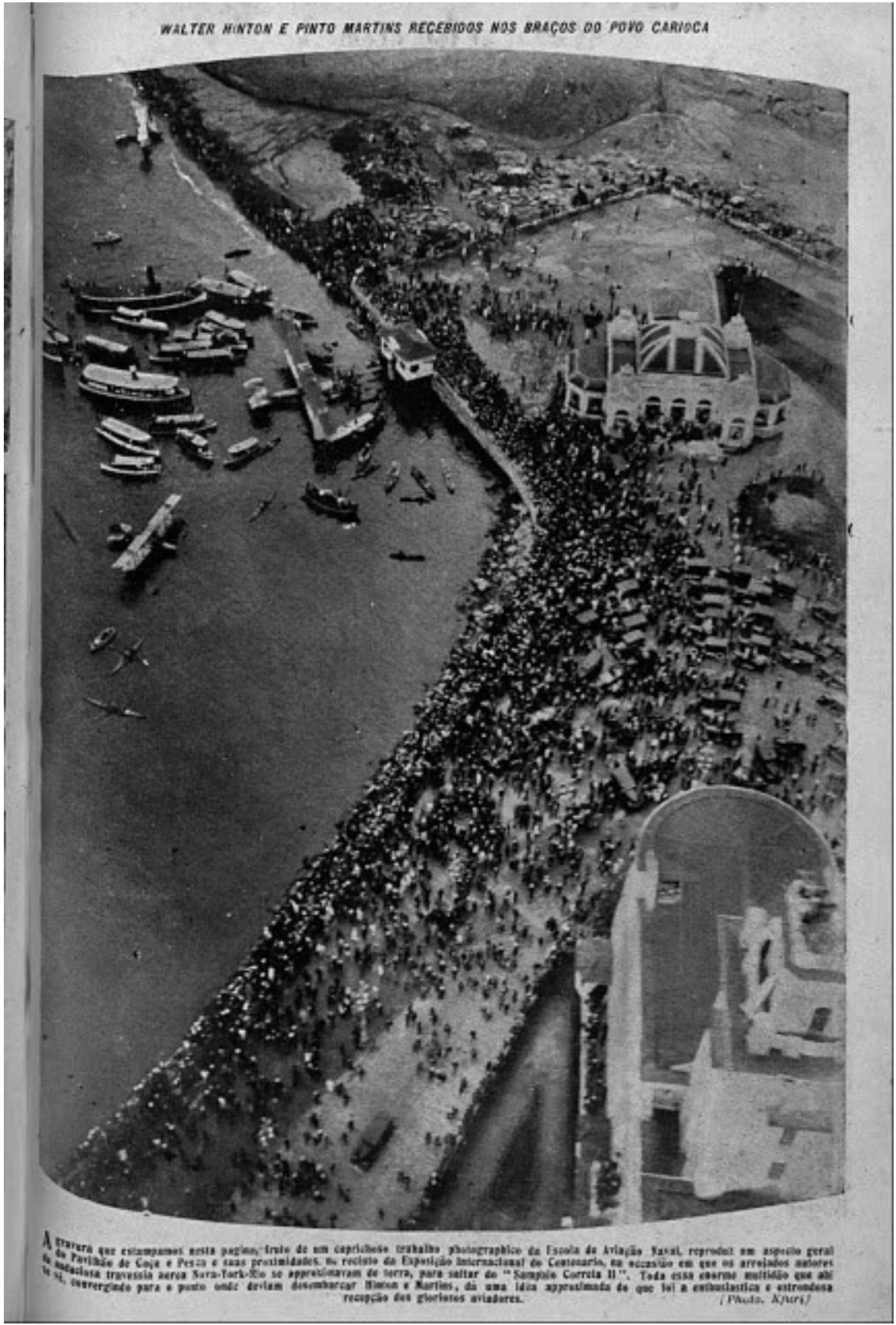

Vista aérea da recepção à Pinto Martins e Walter Hinton. Rio de Janeiro. 1923. Fonte: Revista Fon Fon. n07, p. 31. 1913. Rio de Janeiro. 


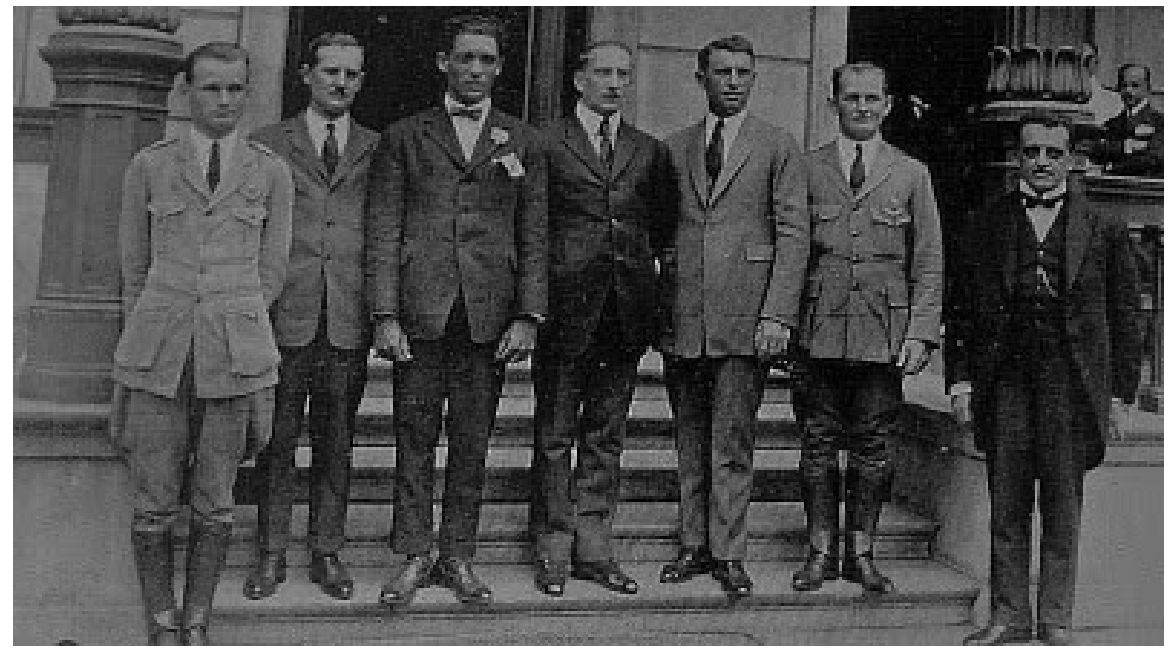

Ao centro Presidente Arthur Bernardes, tendo à esquerda Pinto Marins e à direita Walter Hinton. Fonte: Revista O Malho 1066, p. 27. 1923. Rio de Janeiro.

Contudo, toda modernidade tem seu preço. O mesmo Presidente Arthur Bernardes que confraterniza com Pinto Martins pelo feito aeronáutico autoriza o uso do bombardeio de São Paulo durante a Revolta Tenentista (1924), 288 feito com o uso de aviões.

\section{Considerações finais}

Poderíamos ainda relacionar fatos da Revolução de 1930 e da Ditadura Vargas que aqui repercutiram, como a prisão do fundador do Partido Comunista em Camocim, Francisco Theodoro Rodrigues, e a perseguição aos demais camaradas do partido até meados dos anos 1980, quando findou a ditadura civil-militar inaugurada em 1964. Assim como poderíamos tecer comentários de como a Igreja Católica combateu o comunismo na cidade e de como as forças conservadoras se organizaram na sociedade civil e na Câmara Municipal durante este percurso de tempo. No entanto, este será um exercício de pesquisa e escrita a ser feito a posteriori.

\section{Fontes}

Manuscritas

Arquivo da Câmara Municipal de Camocim. $1^{\circ}$ Livro de Officios Expedidos, 26/12/1885 a 11/05/1908. 
Fórum de Camocim. Ação declaratória - No 2526. Autora: Angelita Ferreira Fontenele, fl. 2, Ano: 1986. Cx: 114

Impressas

Jornal A Palavra, Anno VIII, no 15, 6 de janeiro de 1912. Camocim-CE, p. 2. Jornal O Momento. Ano 5, no 160, 24 de abril de 1942, Camocim-CE, p. 1. Jornal O Literário. Ano III, Edição 16, maio de 2001. Camocim-CE, p. 5 Jornal A Pátria. Fortaleza-CE, agosto de 1890, p.3.

Jornal Diário do Nordeste. Ano XXV, n 8.360 , quarta-feira, $1^{\circ}$ de março de 2006. Fortaleza-CE, p. 2.

Revista Fon Fon. no 07, p. 31. 1913. Rio de Janeiro.

Revista O Malho, no 1066, p. 27. 1923. Rio de Janeiro. 

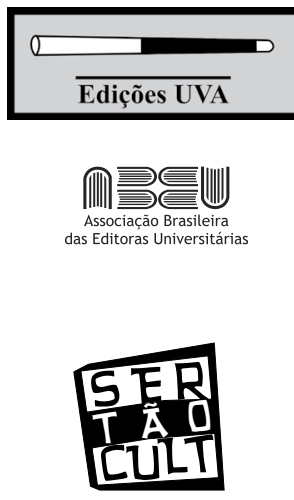

Este livro foi composto em fonte Minion Pro, impresso no formato 15,7 x 22,7 cm, com miolo em papel off set $75 \mathrm{~g}$ e capa em supremo $250 \mathrm{~g}$,

tiragem de 300 exemplares e em e-book formato pdf, em março de 2019. 



\section{Autores desta obra}

Maria Malena Paiva Mesquita, Francisca Clédia Sousa de Oliveira, Letícia Rodrigues Gonçalves,

Caubi Alves Braga, Naiane Nobre Martins, Pedro de Souza Filomeno Filho,

Raimundo Nonato Fernandes, Jaiana Kelly Rodrigues Alcântara, Adelina Lopes Guimarães,

Sebastião Ferreira Carneiro, Paulo Ênio de Sousa Melo, João Henrique Brito Lima,

Natanael Lopes Alves, Vinícius Pereira de Sousa, Alan Silva de Morais,

Antonio Tarciano Aragão Sousa, Maria Deiziane Lino, Raimundo Sousa Alves,

Cleane dos Santos de Medeiros, Nilson Almino de Freitas, Francisco Sávio Barbosa do Nascimento,

Odail José Martins Freire, Valério Samaronni Morais de Queiroz, Maely Alves de Mesquita,

Carlos Augusto Pereira dos Santos

Nossa Gente, Nossa História é o resultado da escrita de vinte e três artigos, divididos em quatro partes temáticas que podem ser conferidas no sumário e ao longo do livro. Portanto, empreendemos um mergulho no universo sertanejo, falando da alegria da chegada do inverno, do inferno da seca e das práticas religiosas que beiram o fanatismo (Parte 1). Adentramos no mundo do trabalho e esticamos a jornada para compreendermos os projetos e propostas de escolarização e educação do nosso povo (Parte 2).

Por outro lado, foi necessário falarmos da diversidade cultural que nos caracteriza. O que tem em comum o universo queer no cinema e as sociabilidades homoafetivas no espaço citadino? O que um pai de santo e um conjunto de mulheres rezadeiras podem nos dizer sobre a prática da cura? Quais são as fronteiras culturais entre dançadores de reisado, jovens bailarinos da periferia e a obra do cantor Belchior? São interrogações que poderão ser respondidas, ou não, lendo-se o conjunto de artigos da Parte 3. Finalizando, como a política e a economia interferem no cotidiano de uma cidade? É o que os autores propõem discutir na Parte 4, evidenciando as características singulares na história dos municípios de Ibiapina e Camocim. 